Prepared in cooperation with Meagher County Conservation District

\title{
Groundwater and Surface-Water Interaction within the Upper Smith River Watershed, Montana, 2006-2010
}

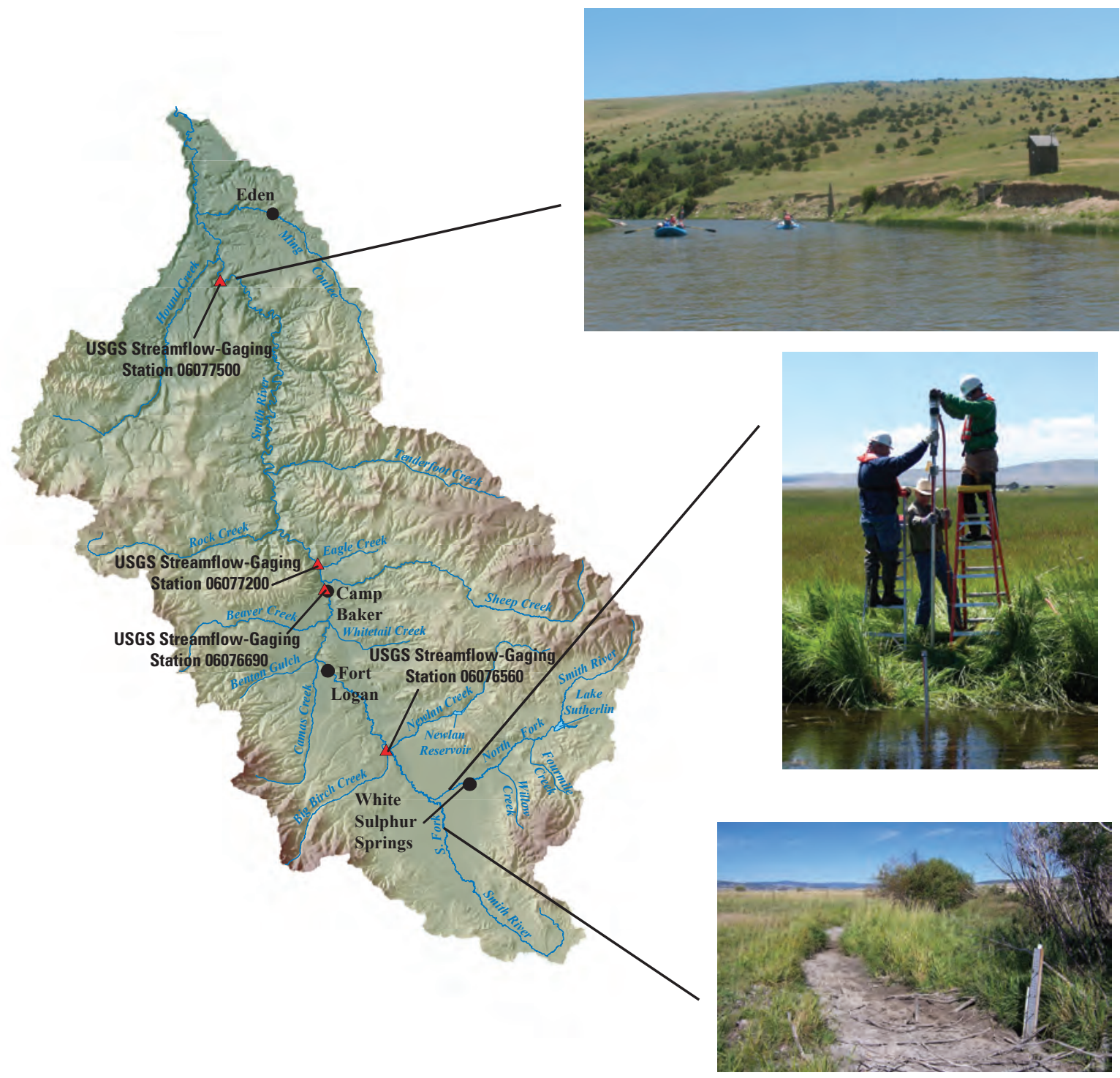

Scientific Investigations Report 2013-5051 


\section{Front cover.}

Upper right: USGS streamflow-gaging station at the Smith River near Eden, Mont., July 4, 2012. Photo taken by Abigail L. Caldwell.

Center right: Installation of monitoring well at North Fork Smith River near mouth near White Sulphur Springs, Mont., July 13, 2006. Photo taken by James Constantz, U.S. Geological Survey.

Lower right: Monitoring well and temporary streamflow-gaging station at the South Fork Smith River, 4.8 miles below Cottonwood Creek, near White Sulphur Springs, Mont. August 29, 2008. Photo taken by Rodney R. Caldwell, U.S. Geological Survey.

\section{Back cover.}

Upper: Survey of monitoring wells and temporary streamflow-gaging station at the Smith River below North Fork Smith River, near White Sulphur Springs, Mont. July 31, 2007. Photo taken by Rodney R. Caldwell, U.S. Geological Survey.

Lower: Aerial photo looking east with the Smith River and the USGS streamflow-gaging station at the Smith River below Newlan Creek near White Sulpur Springs, Mont. in the foreground and the mouths of Newlan Creek and Big Birch Creek near the center of the picture, August 26, 2006. Photo taken by Rodney R. Caldwell, U.S. Geological Survey. 


\section{Groundwater and Surface-Water Interaction within the Upper Smith River Watershed, Montana, 2006-2010}

By Rodney R. Caldwell and Cheryl A. Eddy-Miller

Prepared in cooperation with Meagher County Conservation District

Scientific Investigations Report 2013-5051 


\title{
U.S. Department of the Interior \\ SALLY JEWELL, Secretary
}

\author{
U.S. Geological Survey \\ Suzette M. Kimball, Acting Director
}

U.S. Geological Survey, Reston, Virginia: 2013

For more information on the USGS - the Federal source for science about the Earth, its natural and living resources, natural hazards, and the environment, visit http://www.usgs.gov or call 1-888-ASK-USGS.

For an overview of USGS information products, including maps, imagery, and publications, visit http://www.usgs.gov/pubprod

To order this and other USGS information products, visit http://store.usgs.gov

Any use of trade, firm, or product names is for descriptive purposes only and does not imply endorsement by the U.S. Government.

Although this information product, for the most part, is in the public domain, it also may contain copyrighted materials as noted in the text. Permission to reproduce copyrighted items must be secured from the copyright owner.

Suggested citation:

Caldwell, R.R., and Eddy-Miller, C.A., 2013, Groundwater and surface-water interaction within the upper Smith River Watershed, Montana 2006-2010: U.S. Geological Survey Scientific Investigations Report 2013-5051, 88 p.,

http://dx.doi.org/10.3133/sir20135051.

ISSN 2328-031X (print) ISSN 2328-0328 (online) ISBN 978-1 4113 3721-3 


\section{Acknowledgments}

We gratefully acknowledge the landowners who gave access to their property for the acquisition of data. We also thank members of the Meagher County Conservation District that have supported this project. Special thanks to Otto Olson for his local knowledge and contribution of groundwater levels and Newlan Creek Reservoir data. Kathy Hochstrat provided streamflow and diversion information for the North Fork Smith River. Several scientists with the Montana Department of Natural Resources and Conservation including Larry Dolan, Russell Levens, Mike Roberts, and Bill Uthman provided background information including access to hydrologic data collected in the area.

This work was completed through the combined effort and expertise of several USGS colleagues during the collection, compilation, and analysis of hydrologic data including streamflow measurements, surveys, well installation, and groundwater levels. These colleagues included Fred Bailey, Craig Bowers, Tom Cleasby, Phil Karper, Sean Lawlor, Steve Lynn, Peter McCarthy, Steve Nichols, David Nimick, Kevin Sattler, Todd Schmidt, William Stotts, Andy Skerda, and Andrea Stanley. DeAnn Dutton provided field time and was the primary Geographic Information System specialist for this project. Hannah Nilges provided field time and a thorough review and compilation of the data collected for this study. Michael Cannon was involved in the early phases of study design, field work, and data interpretation. A special thanks to Ron Shields (USGS, retired) who graciously volunteered several days in the field, verified data, and provided guidance on many aspects of this study. Jim Constantz (USGS, National Research Program) provided detailed guidance throughout the project from the initial groundwater and surface-water interaction monitoring network design, implementation in the field, and assistance with the analysis of the data collected. 


\section{Contents}

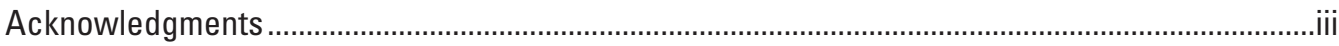

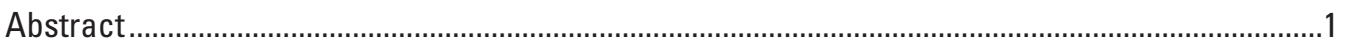

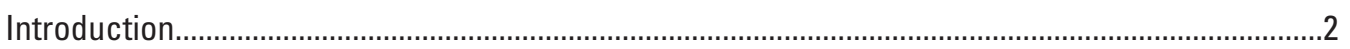

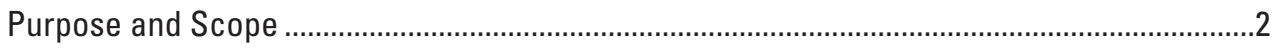

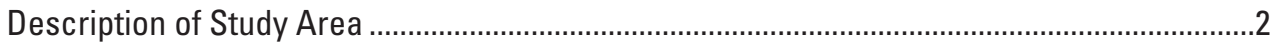

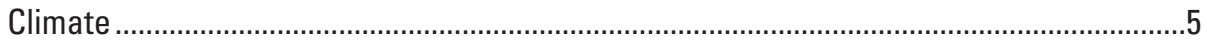

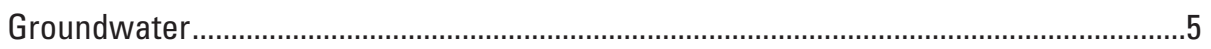

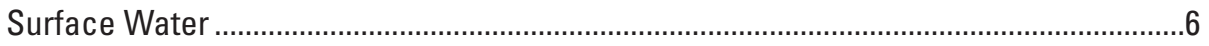

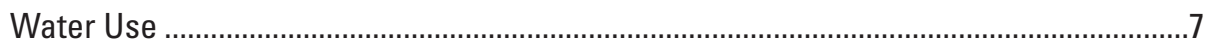

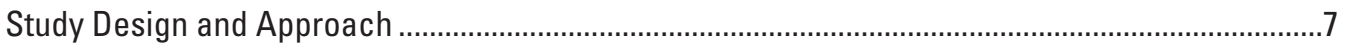

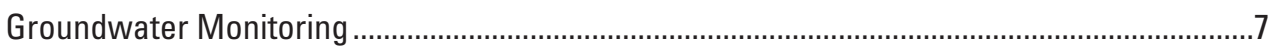

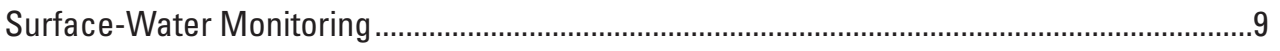

Synoptic Streamflow Measurements.........................................................................

Groundwater and Surface-Water Interaction Monitoring Networks ....................................15

Monitoring and Modeling of Heat Transport....................................................................15

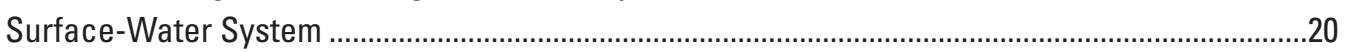

Streamflow at Long-Term USGS Streamflow-Gaging Stations.............................................20

Streamflow at Temporary USGS Streamflow-Gaging Stations ...............................................23

Groundwater and Surface-Water Interaction within the Upper Smith River Watershed ...............23

Generalized Groundwater Flow Direction and Streamflow Gains and Losses ......................23

Period of Limited Irrigation (October to April) ...............................................................23

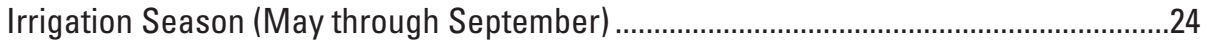

Estimated Groundwater Discharge and the Effects of Irrigation Practices on

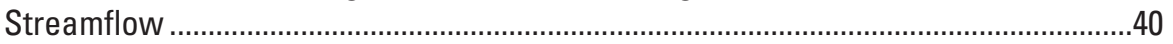

Qualitative Interpretation of Temperature and Water-Level Data ...........................................42

South Fork Smith River at Birky Road (Groundwater and Surface-Water Monitoring Site 1) ..........................................................................................

South Fork Smith River 4.8 Miles below Cottonwood Creek (Groundwater and Surface-Water Monitoring Site 2) ......................................................................4

South Fork Smith River near Mouth (Groundwater and Surface-Water Monitoring Site 3) ............................................................................................

North Fork Smith River near Mouth (Groundwater and Surface-Water Monitoring Site 4) ..........................................................................................52

Smith River below North Fork Smith River (Groundwater and Surface-Water

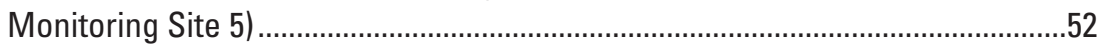

Smith River at Birch Creek Road and Smith River below Woods Gulch (Groundwater and Surface-Water Monitoring Sites 6 and 7).............................53

Smith River above Mud Springs Creek (Groundwater and Surface-Water Monitoring Site 8) ...........................................................................................58

Smith River below Newlan Creek (Groundwater and Surface-Water Monitoring Site 9)

Smith River above Rock Springs Creek (Groundwater and Surface-Water Monitoring Site 10) 
Simulated Water Fluxes between Groundwater and Surface Water .....................................65

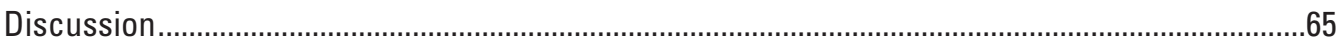

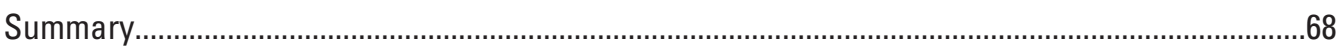

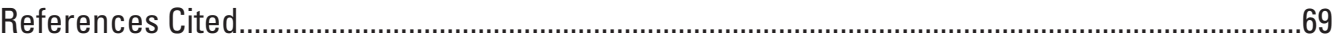

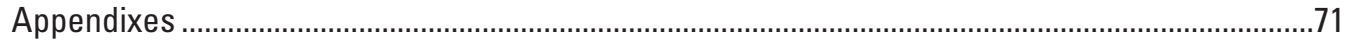

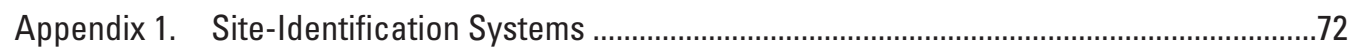

Appendix 2. Cross-Sectional Model Descriptions and Results ...................................................73

South Fork Smith River near Mouth................................................................................

North Fork Smith River near Mouth ............................................................................

Smith River above Mud Springs Creek ..........................................................................76

Appendix 3. Water Flux Calculations of Cross-Section Models................................................80

South Fork Smith River near Mouth.........................................................................8

North Fork Smith River near Mouth ..........................................................................80

Smith River above Mud Springs Creek .....................................................................80

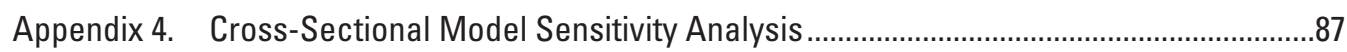

\section{Figures}

1. Location of Smith River watershed, Montana …….............................................................

2. Generalized geology of the Smith River watershed, Montana ..........................................4

3. Monthly mean precipitation at White Sulphur Springs and at Deadman Creek in the Little Belt Mountains north of White Sulphur Springs, Montana, 2006-2010. Data from National Weather Service station White Sulphur Springs 2 and the Natural Resources Conservation Service Deadman Creek Snowpack Telemetry (SNOTEL) site.

4. Location of wells used in the study of the upper Smith River watershed, Montana

5. Location of U.S. Geological Survey streamflow-gaging stations in the upper Smith River watershed, Montana

6. Location of synoptic streamflow measurement sites in the upper Smith River watershed, Montana

7. Daily mean streamflow at the Smith River below Newlan Creek near White Sulphur Springs, Montana U.S. Geological Survey streamflow-gaging station (station 06076560) and corresponding synoptic streamflow measurement dates, water years 2007 and 2008

8. Location of groundwater and surface-water interaction monitoring sites in the upper Smith River watershed, Montana

9. Channel geometry, monitoring well network, and thermistor and/or pressure transducer locations at the Smith River below North Fork Smith River monitoring site (station 06075810). Groundwater altitudes and stream stage for May 24, 2007

10. Streambed flow and heat transport in a gaining and a losing stream. $A$, Gaining reach. $B$, Losing reach. (Schematics modified from Constantz and Stonestrom, 2003)

11. Computed daily streamflow at U.S. Geological Survey Smith River streamflowgaging stations on the Smith River for water years 2006 through 2010. 
12. Generalized potentiometric surface, groundwater-flow direction, and delineation of gaining and losing stream reaches during periods of limited diversions, upper Smith River watershed, Montana, 2007-2008. (Based on synoptic measurements during March 2007, October 2007, and April 2008)..

13. Instantaneous streamflow and cumulative tributary inflow of the $A$, South Fork Smith River; $B$, North Fork Smith River; and $C$, upper Smith River, Montana, March 22, 2007

14. Generalized potentiometric surface, groundwater-flow direction, and delineation of gaining and losing stream reaches during irrigation season conditions, upper Smith River watershed, Montana, August 2007.

15. Instantaneous streamflow and cumulative tributary inflow of the $A$, South Fork Smith River; $B$, North Fork Smith River; and $C$, upper Smith River, Montana, August 1, 2007

16. Streamflow at the Smith River below Newlan Creek streamflow-gaging station (station 06076560) and the combined streamflow of major tributaries in the upper Smith River watershed, Montana, April 2010 through September 2010.

17. Water temperature at South Fork Smith River temporary streamflow-gaging stations and local air temperature, upper Smith River watershed, Montana, May 2007 through October 2007 and May 2008 through November 2008.

18. Data collected at the South Fork Smith River at Birky Road monitoring site (station 06075775). A, Altitude of stream stage and groundwater at well SF0606B; $B$, Difference in head between the groundwater at well SF0606B and stream; $C$, Hourly temperature of stream at station and in monitoring well SF0606B at depths of 1.39 feet and 2.89 feet below the streambed; and $D$, Diel temperature variation in monitoring well SF0606B at depths of 1.39 feet and 2.89 feet below the streambed, May 2007 through November 2007 and March 2008 through December 2008.

19. Data collected at the South Fork Smith River monitoring site (station 06075780) 4.8 mi below Cottonwood Creek. $A$, Altitude of stream stage and groundwater at well SF0605; $B$, Difference in hydraulic head between groundwater and stream; $C$, Hourly temperature measurements of air at station 06075785 , in stream at the South Fork Smith River (station 06075780), and in monitoring well SF0605 at depths of $1.48 \mathrm{ft}$ and $2.98 \mathrm{ft}$ below the streambed; and $D$, Diel temperature variation in monitoring well SF0605 at depths of $1.48 \mathrm{ft}$ and $2.98 \mathrm{ft}$ below the streambed, March 2007 through November 2007 and April 2008 through December 2008.

20. Channel geometry, monitoring well network, and thermistor and/or pressure transducer locations at South Fork Smith River near mouth monitoring site (station 06075785). Groundwater altitudes and stream stage for May 11, 2007.

21. Data collected at the South Fork Smith River near mouth monitoring site (station 06075785). A, Altitude of stream stage and groundwater at well SF0603; $B$, Difference in hydraulic head between the groundwater at well SF0603 and stream; $C$, Hourly temperature measurements of air at station 06075785, stream at station 06075785, in monitoring well SF0603 at depths of $1.65 \mathrm{ft}$ and $3.15 \mathrm{ft}$ below the streambed; and $D$, Diel temperature variation in monitoring well SF0603 at depths of $1.65 \mathrm{ft}$ and $3.15 \mathrm{ft}$ below the streambed, March 2007 through December 2007 and March 2008 through December 2008.

22. Channel geometry, monitoring well network, and thermistor and/or pressure transducer locations at North Fork Smith River near mouth monitoring site (station 06075700). Groundwater altitudes and stream stage for May 11, 2007. 
23. Data collected at the North Fork Smith River near mouth monitoring site (station 06075700). A, Altitude of stream stage and groundwater at well NF0602; $B$, Difference in hydraulic head between the groundwater at well NF0602 and stream; $C$, Hourly temperature measurements of air at station 06075785 , stream at station 06075700, and in monitoring well NF0602 at depths of $1.42 \mathrm{ft}$ and $2.92 \mathrm{ft}$ below the streambed; and $D$, Diel temperature variation in monitoring well NF0602 at depths of $1.42 \mathrm{ft}$ and $2.92 \mathrm{ft}$ below the streambed, March 2007 through December 2007 and March 2008 through December 2008.

24. Data collected at the Smith River below North Fork Smith River monitoring site (station 06075810). A, Altitude of stream stage and groundwater at well SR0616; $B$, Difference in hydraulic head between groundwater at well SR0616 and stream; $C$, Hourly temperature measurements of air at station 06075785 , in stream at station 06075810, and in monitoring well SR0616 at depths of $1.72 \mathrm{ft}$ and $3.22 \mathrm{ft}$ below the streambed; and $D$, Diel temperature variation in monitoring well SR0616 at depths of $1.72 \mathrm{ft}$ and $3.22 \mathrm{ft}$ below the streambed, March 2007 through November 2007 and March 2008 through December 2008.

25. Channel geometry, monitoring well network, and thermistor and/or pressure transducer locations at Smith River above Mud Springs Creek monitoring site (station 06075850). Groundwater altitudes and stream stage for April 30, 2008.

26. Data collected at the Smith River above Mud Springs Creek monitoring site (station 06075850). A, Altitude of stream stage and groundwater at well SR0609; $B$, Difference in hydraulic head between groundwater at well SR0609 and stream; $C$, Hourly temperature measurements of air at station 06075785 , in stream at station 06075850, and in monitoring well SR0609 at depths of $1.4 \mathrm{ft}$ and $2.9 \mathrm{ft}$ below the streambed; and $D$, Diel temperature variation in monitoring well SR0609 at depths of $1.4 \mathrm{ft}$ and $2.9 \mathrm{ft}$ below the streambed, March 2007 through December 2007 and March 2008 through December 2008.

27. Channel geometry, monitoring well network, and thermistor and/or pressure transducer locations at Smith River above Rock Springs Creek monitoring site (station 06076580). Groundwater altitudes and stream stage for May 9, 2007.

28. Data collected at the Smith River above Rock Springs Creek monitoring site (station 06076580). A, Altitude of stream stage and groundwater at well SR0605; $B$, Difference in hydraulic head between groundwater at wells SR0605 and SR0606B and stream; $C$, Hourly temperature measurements of air at station 06075785, in stream at station 06076580, and in monitoring well SR0605 at depths of $1.6 \mathrm{ft}$ and $3.1 \mathrm{ft}$ below the streambed; and $D$, Diel temperature variation in monitoring well SR0605 at depths of $1.6 \mathrm{ft}$ and $3.1 \mathrm{ft}$ below the streambed, March 2007 through November 2007 and March 2008 through December, 2008

\section{Appendix Figures}

1-1. Location-numbering system for wells.

2-1. Boundary conditions and observation points for the VS2DH model, South Fork

Smith River near mouth (station 06075785) monitoring site cross section...

2-2. Observed and simulated temperature for the South Fork Smith River near mouth monitoring site (station 06075785), 2007 and 2008. (Horizontal and vertical hydraulic conductivities were set at $3 \times 10^{-6}$ feet per second.)

2-3. Boundary conditions and observation points for the VS2DH model, North Fork Smith River near mouth (station 06075700) monitoring site cross section. 
2-4. Observed and simulated temperature for the North Fork Smith River near mouth monitoring site (station 06075700), 2007 and 2008. (Horizontal and vertical hydraulic conductivities were set at $3 \times 10^{-6}$ feet per second)

2-5. Boundary conditions and observation points for the VS2DH model, Smith River above Mud Springs Creek (station 06075850) monitoring site cross section .78

2-6. Observed and simulated temperatures for the Smith River above Mud Springs Creek monitoring site (station 06075850), 2008. (Horizontal and vertical hydraulic conductivities were set at $4 \times 10^{-5}$ feet per second.)

3-1. Water-flux information, in cubic feet per day $\left(\mathrm{ft}^{3} / \mathrm{d}\right)$, for the South Fork Smith River near mouth (station 06075785) modeled cross section. $A$, Location of model boundaries; $B$, Daily flux across model boundaries, 2007; $C$, Daily flux across model boundaries, 2008; and $D$, Simulated temperature distributions inside the model domain on three selected dates (arrows indicate direction and magnitude of water flux). Flux estimates for the streambed boundary (blue lines) are shown as positive when water is moving from the groundwater system to the stream and negative when moving from the stream to the groundwater system. Flux estimates from the bottom and side boundaries (black, red, and purple lines) are positive when the water flux is into the surrounding groundwater system and negative when the water flux past the boundary is into the stream.

3-2. Water-flux information, in cubic feet per day $\left(\mathrm{ft}^{3} / \mathrm{d}\right)$, for the North Fork Smith River near mouth (station 06075700) modeled cross section. $A$, Location of model boundaries; $B$, Daily flux across model boundaries, 2007; $C$, Daily flux across model boundaries, 2008; and $D$, Simulated temperature distributions inside the model domain on three selected dates (arrows indicate direction of water flux). Flux estimates for the streambed boundary (blue lines) are shown as positive when water is moving from the groundwater system to the stream and negative when moving from the stream to the groundwater system. Flux estimates for the bottom and side boundaries (black, red, and purple lines) are positive when the water flux is into the surrounding groundwater system and negative when the water flux past the boundary is into the stream

3-3. Water-flux information, in cubic feet per day $\left(\mathrm{ft}^{3} / \mathrm{d}\right)$, for the Smith River above Mud Springs Creek (station 06075850) modeled cross section. $A$, Location of model boundaries; $B$, Daily flux across model boundaries, 2008; and $C$, Simulated temperature distributions inside the model domain on three selected dates (arrows indicate direction of water flux). Flux estimates for the streambed boundary (blue lines) are shown as positive when water is moving from the groundwater system to the stream and negative when moving from the stream to the groundwater system. Flux estimates for the bottom and side boundaries (black, red, and purple lines) are positive when the water flux is into the surrounding groundwater system and negative when the water flux past the boundary is into the stream

4-1. Observed and simulated temperatures with varied hydraulic conductivity values and ratios of vertical (Kv) to horizontal (Kh) hydraulic conductivity of the VS2DH 2-dimensional model of the Smith River above Mud Springs Creek monitoring site (station 06075850), 2008. 


\section{Tables}

1. U.S. Geological Survey streamflow-gaging stations in the Smith River watershed,

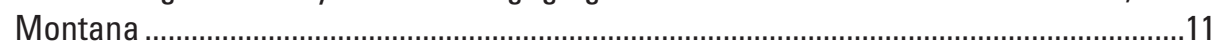

2. Site descriptions and locations for synoptic streamflow measurements in the upper Smith River watershed, Montana...

3. Groundwater and surface-water interaction monitoring sites in the upper Smith River watershed, Montana

4. Summary of gains and losses calculated from synoptic streamflow measurements during periods of limited diversions, upper Smith River watershed, Montana, 2007-08

5. Estimated streamflow gains and losses, upper Smith River watershed, Montana, March 22, 2007 ....

6. Estimated streamflow gains and losses, upper Smith River watershed, October 16, 2007

7. Estimated streamflow gains and losses, upper Smith River watershed, April 10, 2008

8. Estimated streamflow gains and losses, upper Smith River watershed, Montana, August 1, 2007.

9. Summary of hydraulic parameters used in final calibrated VS2DH simulations of selected modeled cross sections in the upper Smith River watershed, Montana..........66

10. Summary of estimated water flow across streambed boundaries of the South Fork Smith River, North Fork Smith River, and Smith River modeled cross sections ......66 


\section{Conversion Factors, Datum, and Acronyms}

\begin{tabular}{|c|c|c|}
\hline Multiply & By & To obtain \\
\hline \multicolumn{3}{|c|}{ Length } \\
\hline inch (in.) & 2.54 & centimeter $(\mathrm{cm})$ \\
\hline inch (in.) & 25.4 & millimeter (mm) \\
\hline foot (ft) & 0.3048 & meter $(\mathrm{m})$ \\
\hline mile (mi) & 1.609 & kilometer $(\mathrm{km})$ \\
\hline \multicolumn{3}{|c|}{ Area } \\
\hline acre & 4,047 & square meter $\left(\mathrm{m}^{2}\right)$ \\
\hline square mile $\left(\mathrm{mi}^{2}\right)$ & 2.590 & square kilometer $\left(\mathrm{km}^{2}\right)$ \\
\hline \multicolumn{3}{|c|}{ Volume } \\
\hline gallon (gal) & 3.785 & liter $(\mathrm{L})$ \\
\hline gallon (gal) & 0.003785 & cubic meter $\left(\mathrm{m}^{3}\right)$ \\
\hline cubic foot $\left(\mathrm{ft}^{3}\right)$ & 0.02832 & cubic meter $\left(\mathrm{m}^{3}\right)$ \\
\hline acre-foot (acre-ft) & 1,233 & cubic meter $\left(\mathrm{m}^{3}\right)$ \\
\hline \multicolumn{3}{|c|}{ Flow rate } \\
\hline acre-foot per year (acre-ft/yr) & 1,233 & cubic meter per year $\left(\mathrm{m}^{3} / \mathrm{yr}\right)$ \\
\hline foot per second (ft/s) & 0.3048 & meter per second $(\mathrm{m} / \mathrm{s})$ \\
\hline foot per day (ft/d) & 0.3048 & meter per day $(\mathrm{m} / \mathrm{d})$ \\
\hline foot per year (ft/yr) & 0.3048 & meter per year (m/yr) \\
\hline cubic foot per second $\left(\mathrm{ft}^{3} / \mathrm{s}\right)$ & 0.02832 & cubic meter per second $\left(\mathrm{m}^{3} / \mathrm{s}\right)$ \\
\hline cubic foot per day $\left(\mathrm{ft}^{3} / \mathrm{d}\right)$ & 28.31685 & liters per day $(\mathrm{L} / \mathrm{d})$ \\
\hline cubic foot per month ( $\mathrm{ft}^{3} /$ month) & 0.02832 & liter per second $(\mathrm{L} / \mathrm{s})$ \\
\hline gallon per day (gal/d) & 0.003785 & cubic meter per day $\left(\mathrm{m}^{3} / \mathrm{d}\right)$ \\
\hline million gallons per day (Mgal/d) & 0.04381 & cubic meter per second $\left(\mathrm{m}^{3} / \mathrm{s}\right)$ \\
\hline \multicolumn{3}{|c|}{ Mass } \\
\hline ounce (oz) & 28.35 & gram $(\mathrm{g})$ \\
\hline pound (lb) & 0.4536 & kilogram $(\mathrm{kg})$ \\
\hline
\end{tabular}

Temperature in degrees Celsius $\left({ }^{\circ} \mathrm{C}\right)$ may be converted to degrees Fahrenheit $\left({ }^{\circ} \mathrm{F}\right)$ as follows:

${ }^{\circ} \mathrm{F}=\left(1.8 x^{\circ} \mathrm{C}\right)+32$

Temperature in degrees Fahrenheit $\left({ }^{\circ} \mathrm{F}\right)$ may be converted to degrees Celsius $\left({ }^{\circ} \mathrm{C}\right)$ as follows:

${ }^{\circ} \mathrm{C}=\left({ }^{\circ} \mathrm{F}-32\right) / 1.8$

Vertical coordinate information is referenced to the North American Vertical Datum of 1988 (NAVD 88).

Horizontal coordinate information is referenced to the North American Datum of 1983 (NAD 83)

Altitude, as used in this report, refers to distance above specified vertical datum.

\section{Water-year definition:}

Water year is the 12-month period from October 1 through September 30 of the following calendar year. The water year is designated by the calendar year in which it ends. For example, water year 2007 is the period from October 1, 2006 through September 30, 2007. 


\section{Acronyms and abbreviations used in this report:}

$\begin{array}{ll}\text { E } & \text { east } \\ \text { ET } & \text { evapotranspiration } \\ \text { GIS } & \text { Geographic Information System } \\ \text { GPS } & \text { Global Positioning System } \\ \text { GWIC } & \text { Groundwater Information Center } \\ \text { Isd } & \text { land surface datum } \\ \text { MBMG } & \text { Montana Bureau of Mines and Geology } \\ \text { MCCD } & \text { Meagher County Conservation District } \\ \text { MDNRC } & \text { Montana Department of Resources and Conservation } \\ \text { N } & \text { north } \\ \text { NRCS } & \text { Natural Resources Conservation Service } \\ \text { NWIS } & \text { National Water Information System } \\ \text { RTK } & \text { Real-Time Kinematic } \\ \text { USGS } & \text { U.S. Geological Survey } \\ \text { 2-D } & \text { two-dimensional }\end{array}$




\title{
Ground water and Surface-Water Interaction within the Upper Smith River Watershed, Montana, 2006-2010
}

\author{
By Rodney R. Caldwell and Cheryl A. Eddy-Miller
}

\section{Abstract}

The 125-mile long Smith River, a tributary of the Missouri River, is highly valued as an agricultural resource and for its many recreational uses. During a drought starting in about 1999, streamflow was insufficient to meet all of the irrigation demands, much less maintain streamflow needed for boating and viable fish habitat. In 2006, the U.S. Geological Survey, in cooperation with the Meagher County Conservation District, initiated a multi-year hydrologic investigation of the Smith River watershed. This investigation was designed to increase understanding of the water resources of the upper Smith River watershed and develop a detailed description of groundwater and surface-water interactions. A combination of methods, including miscellaneous and continuous groundwater-level, stream-stage, water-temperature, and streamflow monitoring was used to assess the hydrologic system and the spatial and temporal variability of groundwater and surfacewater interactions. Collectively, data are in agreement and show: (1) the hydraulic connectedness of groundwater and surface water, (2) the presence of both losing and gaining stream reaches, (3) dynamic changes in direction and magnitude of water flow between the stream and groundwater with time, (4) the effects of local flood irrigation on groundwater levels and gradients in the watershed, and (5) evidence and timing of irrigation return flows to area streams.

Groundwater flow within the alluvium and older (Tertiary) basin-fill sediments generally followed land-surface topography from the uplands to the axis of alluvial valleys of the Smith River and its tributaries. Groundwater levels were typically highest in the monitoring wells located within and adjacent to streams in late spring or early summer, likely affected by recharge from snowmelt and local precipitation, leakage from losing streams and canals, and recharge from local flood irrigation. The effects of flood irrigation resulted in increased hydraulic gradients (increased groundwater levels relative to stream stage) or even reversed gradient direction at several monitoring sites coincident with the onset of nearby flood irrigation. Groundwater-level declines in mid-summer were due to groundwater withdrawals and reduced recharge from decreased precipitation, increased evapotranspiration, and reduced leakage in some area streams during periods of low flow. Groundwater levels typically rebounded in late summer, a result of decreased evapotranspiration, decreased groundwater use for irrigation, increased flow in losing streams, and the onset of late-season flood irrigation at some sites.

The effect of groundwater and surface-water interactions is most apparent along the North and South Forks of the Smith River where the magnitude of streamflow losses and gains can be greater than the magnitude of flow within the stream. Net gains consistently occurred over the lower 15 miles of the South Fork Smith River. A monitoring site near the mouth of the South Fork Smith River gained (flow from the groundwater to the stream) during all seasons, with head gradients towards the stream. Two upstream sites on the South Fork Smith River exhibited variable conditions that ranged from gaining during the spring, losing (flowing from the stream to the groundwater) during most of the summer as groundwater levels declined, and then approached or returned to gaining conditions in late summer. Parts of the South Fork Smith River became dry during periods of losing conditions, thus classifying this tributary as intermittent. The North Fork Smith River is highly managed at times through reservoir releases. The North Fork Smith River was perennial throughout the study period although irrigation diversions removed a large percentage of streamflow at times and losing conditions persisted along a lower reach. The lowermost reach of the North Fork Smith River near its mouth transitioned from a losing reach to a gaining reach throughout the study period.

Groundwater and surface-water interactions occur downstream from the confluence of the North and South Fork Smith Rivers, but are less discernible compared to the overall magnitude of the main-stem streamflow. The Smith River was perennial throughout the study. Monitoring sites along the Smith River generally displayed small head gradients between the stream and the groundwater, while one site consistently showed strongly gaining conditions. Synoptic streamflow measurements during periods of limited irrigation diversion in 2007 and 2008 consistently showed gains over the upper 41.4 river miles of the main stem Smith River where net gains ranged from 13.0 to 28.9 cubic feet per second. Continuous streamflow data indicated net groundwater discharge and small-scale tributary inflow contributions of around 25 cubic feet per second along the upper 10-mile reach of the Smith River for most of the 2010 record. A period of intense irrigation withdrawal during the last two weeks in 
May was followed by a period (early June 2010 to mid-July 2010) with the largest net increase (an average of 71.1 cubic feet per second) in streamflow along this reach of the Smith River. This observation is likely due to increased groundwater discharge to the Smith River resulting from irrigation return flow. By late July, the apparent effects of return flows receded, and the net increase in streamflow returned to about 25 cubic feet per second.

Two-dimensional heat and solute transport VS2DH models representing selected stream cross sections were used to constrain the hydraulic properties of the Quaternary alluvium and estimate temporal water-flux values through model boundaries. Hydraulic conductivity of the Quaternary alluvium of the modeled sections ranged from $3 \times 10^{-6}$ to $4 \times 10^{-5}$ feet per second. The models showed reasonable approximations of the streambed and shallow aquifer environment, and the dynamic changes in water flux between the stream and the groundwater through different model boundaries.

\section{Introduction}

The Smith River watershed is an important agricultural and recreational area in Meagher and Cascade Counties in west-central Montana (fig. 1). Nearly 35,000 acres of the Smith River watershed are irrigated, primarily with water directly withdrawn from the Smith River and its tributaries (Cannon and Johnson, 2004). Downstream (northward), the agricultural fields are replaced by a scenic canyon that draws thousands of recreationists each year. During a recent drought, which started in about 1999, streamflow was insufficient to meet all of the irrigation demands, much less maintain streamflow needed for boating and viable fish habitat (Montana Department of Natural Resources and Conservation, 2003). Largely in response to the lack of available surface water for irrigation, some irrigators have already switched, or are proposing to switch, from flood irrigation to sprinkler irrigation (Montana Department of Natural Resources and Conservation, 2003). Additionally, some irrigators have considered using groundwater instead of surface water as a source of irrigation water. The effects of these changes in irrigation practices on the Smith River watershed are unknown.

In April 2006, the U.S. Geological Survey (USGS), in cooperation with the Meagher County Conservation District (MCCD), began a study of the hydrogeology of the Smith River Watershed. The project was supported through the combined resources of the Montana Department of Natural Resources and Conservation's (MDNRC) Reclamation and Development Grants Program and the USGS Cooperative Water Program. The study was designed to improve understanding of the groundwater system with an emphasis on groundwater and surface-water interactions through a systematic program of data collection, research, and analysis. The findings of this study can assist water managers with the development of a comprehensive management program for the use and protection of water resources in the Smith River watershed.

This report is the second in a series of reports describing the water resources of the Smith River watershed. The first report (Nilges and Caldwell, 2012) is a USGS Open-File report that summarizes the hydrologic data collected and compiled for the hydrogeologic study of Smith River watershed through water year 2010. This report describes the general hydrology and groundwater and surface-water interactions within the upper watershed based on collected data.

\section{Purpose and Scope}

The purpose of this report is to describe the spatial and temporal interactions of groundwater and surface water in the upper Smith River watershed. The description of groundwater and surface-water interactions includes: (1) generalized groundwater-flow direction, (2) the delineation of gaining (flow from the groundwater to the stream) and losing (flow from the stream to the groundwater) reaches of the upper Smith River and selected tributaries, (3) quantification of gains and losses under different hydrologic conditions, (4) the relation between groundwater levels and stream stage, (5) hydraulic properties of the Quaternary alluvium, and (6) estimated water fluxes between groundwater and surface water at selected stream cross sections.

\section{Description of Study Area}

The Smith River is a tributary to the Missouri River with a watershed encompassing approximately 2,000 square miles $\left(\mathrm{mi}^{2}\right)$ or nearly 1.3 million acres in Meagher and Cascade Counties of west-central Montana. Study efforts were focused primarily on the approximately $1,200 \mathrm{mi}^{2}$ in the upper watershed above the Tenderfoot Creek drainage (fig. 1).

The Smith River watershed lies within the structurally complex Northern Rocky Mountains Physiographic Division described by Fenneman and Johnson (1946), is characterized by somewhat rugged mountains, and relatively flat to incised river valleys. Elevations range from about 9,500 feet (ft) in the Big Belt Mountains to about 3,320 ft at the mouth of the Smith River near Ulm, Montana. Sedimentary, igneous, and metamorphic rocks ranging in age from Precambrian to Quaternary are present (fig. 2); the entire sequence of sedimentary rocks, including sandstone, siltstone, shale, limestone, and dolomite, totals approximately $26,000 \mathrm{ft}$ in thickness (Groff, 1965). Runkel (1986) estimated Tertiary-age (65 to 2 million years ago) basin-fill sedimentary deposits may be $1,500 \mathrm{ft}$ thick near White Sulphur Springs. Quaternary alluvium (Qal), which includes gravel, sand, and silt deposits, occurs along the Smith River and its tributaries. Igneous rocks crop out at various locations including an igneous sill located below the mouths of Big Birch and Newlan Creeks incised by the Smith River. 


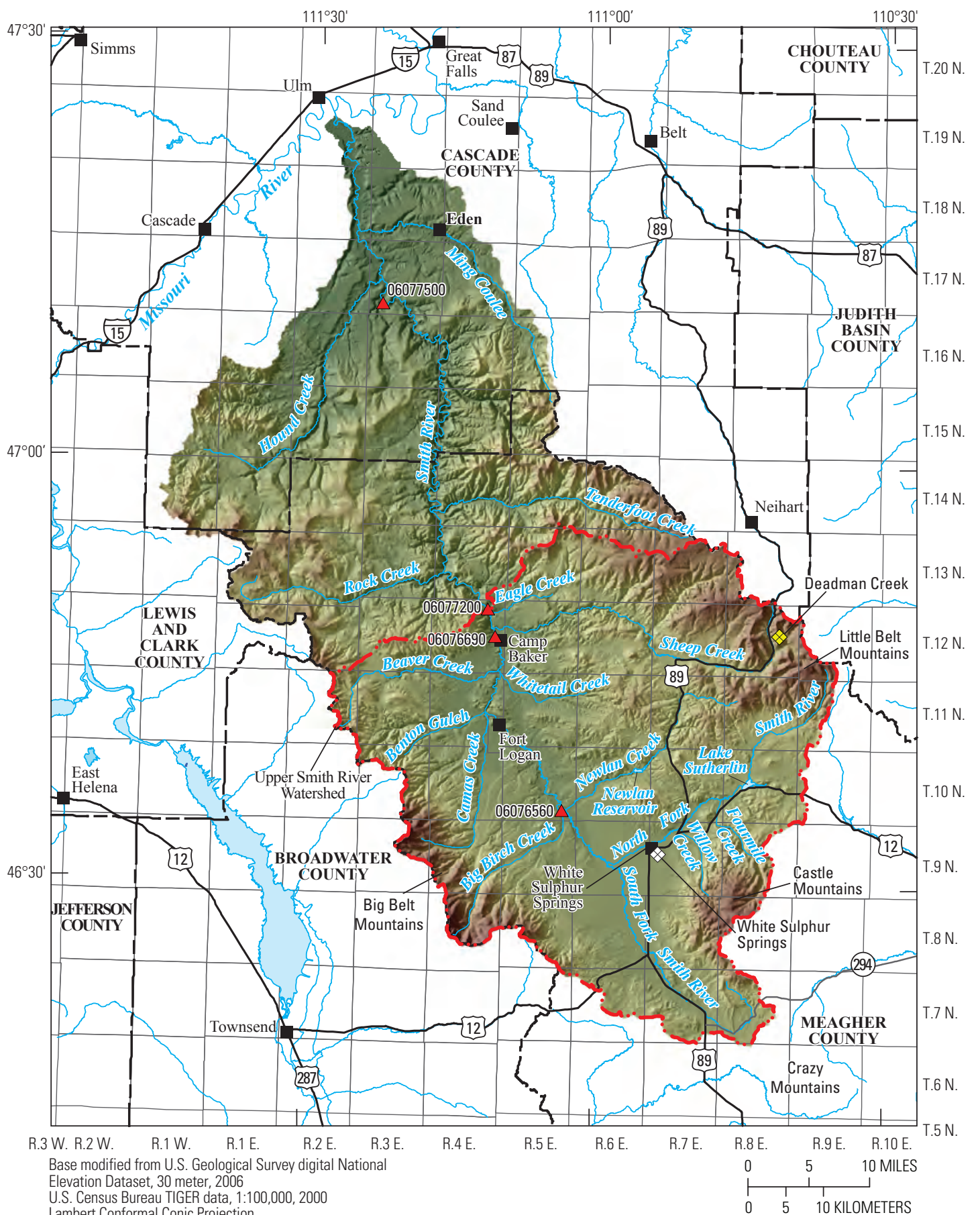

U.S. Census Bureau TIGER data, 1:100,000, 2000

Lambert Conformal Conic Projection

Standard parallels $45^{\circ}$ and $49^{\circ}$, central meridian -109 $30^{\circ}$ North American Datum of 1983 (NAD83)

EXPLANATION
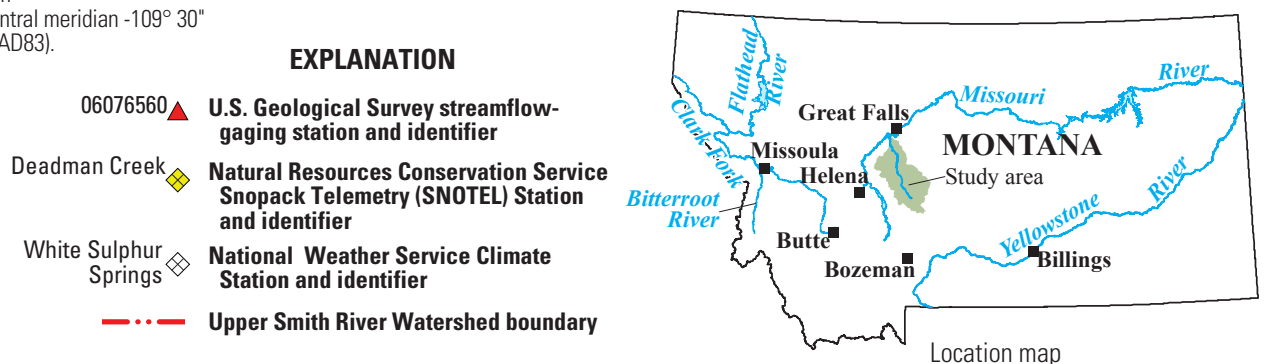

Figure 1. Location of Smith River watershed, Montana. 


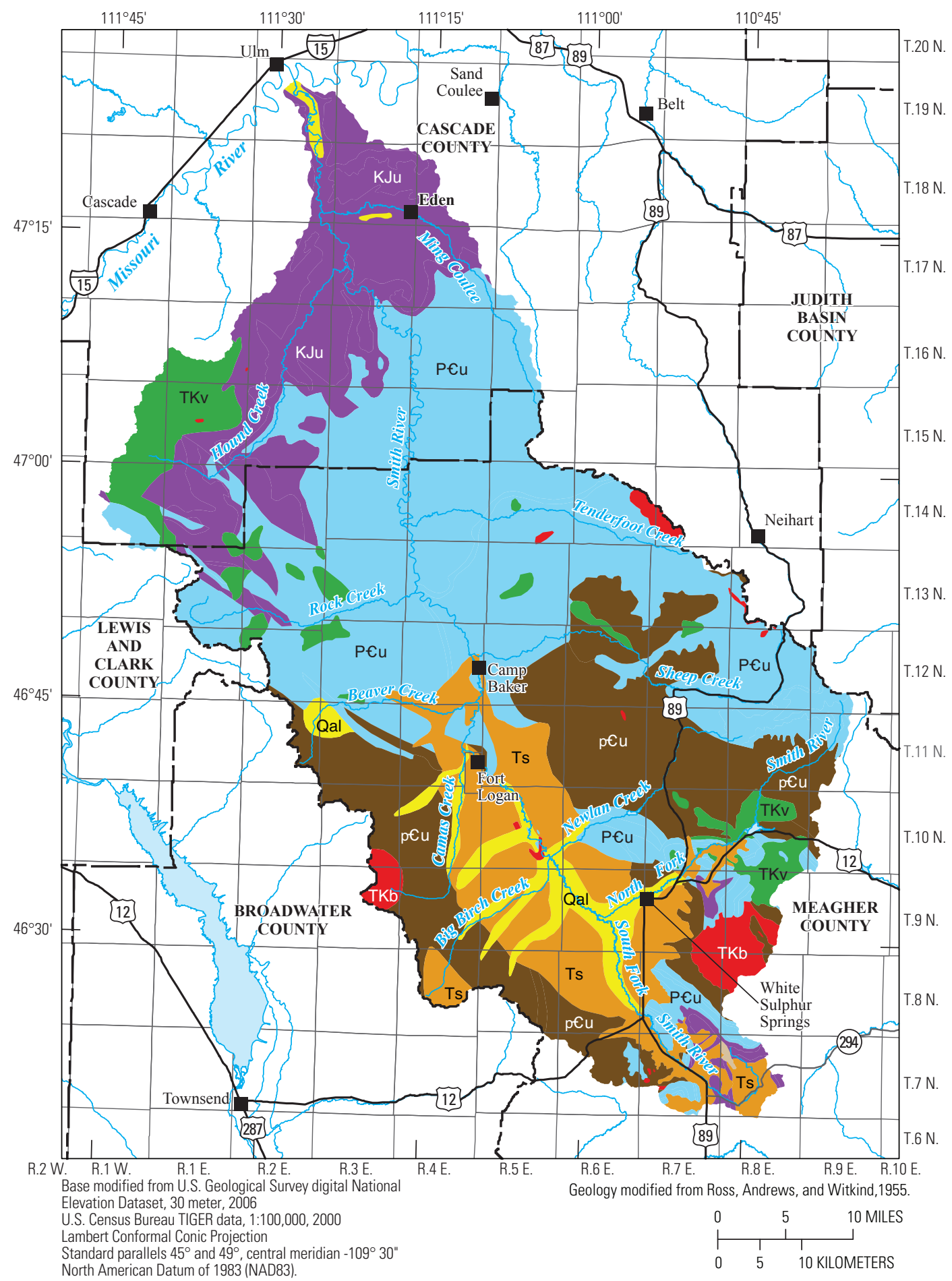

North American Datum of 1983 (NAD83).

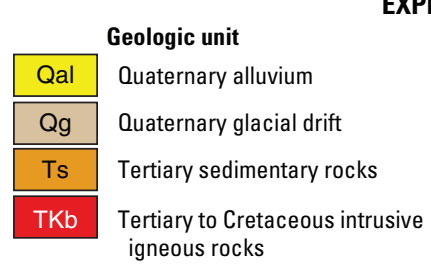

\begin{tabular}{|c|c}
\hline TKv & Tertiary to Cretaceous volcanics \\
\hline KJu & Cretaceous to Jurassic rocks \\
\hline \hline P€u & Permian to Cambrian rocks \\
\hline \hline p€u & Precambrian rocks \\
\hline
\end{tabular}

Figure 2. Generalized geology of the Smith River watershed, Montana. 
Grass and mixed rangeland accounts for the majority (about 55 percent) of the land cover in the watershed (U.S. Geological Survey, 2000). Conifer forests are located at the higher elevations and account for 39 percent of the total area. Pasture and crop lands account for most of the remaining land cover. The more arid lower elevations are dominated by grasslands with riparian vegetation near the streams. The study area contains a low-density rural population of approximately 2,437 people, with 925 of those in the largest community, White Sulphur Springs (U.S. Census Bureau, 2000). Principal industries within the region are dependent upon the natural resources, and include agriculture, forestry, mining, and tourism.

\section{Climate}

Climate in the Smith River watershed is semi-arid with some semi-humid areas in the upper mountains. Summer temperatures are mild in the valleys with cooler temperatures in the higher elevations of the mountains. Monthly mean temperatures during the period of study (2006-2010) near White Sulphur Springs ranged from $14.9^{\circ} \mathrm{F}\left(-9.5^{\circ} \mathrm{C}\right)$ in January 1998 to $72.4^{\circ} \mathrm{F}\left(22.4^{\circ} \mathrm{C}\right)$ in July 2007 (National Climatic Data Center, 2011).

Precipitation varies both spatially and temporally in the Smith River watershed and is highly influenced by orography. Average annual precipitation (1971-2000) ranged from less than 12 inches per year (in/yr) in the lowland to the west and northwest of White Sulphur Springs to over $40 \mathrm{in} / \mathrm{yr}$ in the mountains (Oregon State University PRISM Group, 2006; Farnes, 2007). Monthly mean precipitation during the period of study (calendar years 2006-2010) near White Sulphur Springs (National Weather Service station White Sulphur Springs 2) ranged from 0.01 inch in February 2006 to 3.3 inches in July 2009, whereas monthly mean precipitation at the Deadman Creek Natural Resources Conservation Service (NRCS) Snowpack Telemetry (SNOTEL) site ranged from about 0.7 inches in July 2007 and September 2008 to 6.9 inches in April 2010 (fig. 3). Higher elevations accumulate more precipitation as snowpack and retain it longer into the summer than the lower elevations. The period of snowpack melting in the upper elevations is an important element of the seasonal water budgets.

\section{Groundwater}

Subsurface deposits and geologic formations that are capable of yielding useable quantities of water to wells or springs are classified as aquifers, whereas lower permeability deposits or geologic formations that restrict groundwater movement are classified as confining units (Heath, 1983). Unconfined or "water-table" aquifers occur where the saturated zone of the aquifer can equilibrate to atmospheric pressure and is free to rise and decline (Heath, 1983). Confined aquifers contain groundwater that is confined under pressure between layers of relatively impermeable or significantly less permeable material (Lohman, 1979). The confining unit prevents water in a confined aquifer from equilibrating with atmospheric pressure. The water level in a properly sealed well drilled into a confined aquifer will rise above the top of the aquifer (Heath, 1983). Semi-confined or leaky aquifers are partially confined by layers of low permeability through which water can still flow, but equilibration with atmospheric pressure is impeded (Freeze and Cherry, 1979). The potentiometric surface, which is the hydraulic head (the height above a datum, such as sea level), is an imaginary surface connecting points to which water would rise in tightly cased wells from a given point in an aquifer (Lohman, 1979). The potentiometric surface, like the water table in an unconfined aquifer, rises and falls in response to recharge and discharge of the aquifer.

Unconfined, confined, and semi-confined aquifers occur within the basin-fill deposits (Quaternary alluvium and Tertiary sedimentary deposits) in the Smith River watershed (Montana Department of Natural Resources and Conservation, 2003). The confined and semi-confined units are created by layers of low-permeability material of variable thickness and extent (such as clay layers). Most shallow wells in the study area (generally less than $30 \mathrm{ft}$ deep) completed in Quaternary alluvium appear to be in unconfined aquifers. However, wells completed in Tertiary sediment and deeper wells in Quaternary alluvium may be in unconfined, semi-confined, or confined aquifers, depending on the presence or absence of confining layers. Often, drillers' logs lack sufficient detail to determine if confining layers exist. Therefore, discussions and maps representing groundwater levels within this report are a composite of water levels in confined, semi-confined, and unconfined aquifers and these water levels collectively are herein referred to as the potentiometric surface.

The most productive and developed aquifers in the Smith River watershed are the Quaternary alluvium and the generally weakly consolidated Tertiary sediments of the valley lowlands and tributary drainages (Montana Department of Natural Resources and Conservation, 2003). The Quaternary alluvial aquifers are generally composed of sand and gravel with some clay layers. Most high-yielding wells are completed in the Quaternary alluvium. The Tertiary sedimentary aquifers generally have lower permeability due to the composition of fine-grained sediments. A few high-yielding wells have been completed in the Tertiary sediments, including an exploration well recently drilled for the USGS (Nilges and Caldwell, 2012). A review of documented wells completed in the older sedimentary and igneous rocks included in the Groundwater Information Center (GWIC) database (Montana Bureau of Mines and Geology (MBMG), 2011) indicated that they typically have low yields and are only utilized for domestic and stock purposes.

Recharge to the Quaternary alluvium and Tertiary sediments of the valley lowlands and tributary drainages occur as infiltration from precipitation, leakage from streams and canals, and as leakage from underlying rocks. Discharge from the groundwater system occurs by withdrawal from wells, 


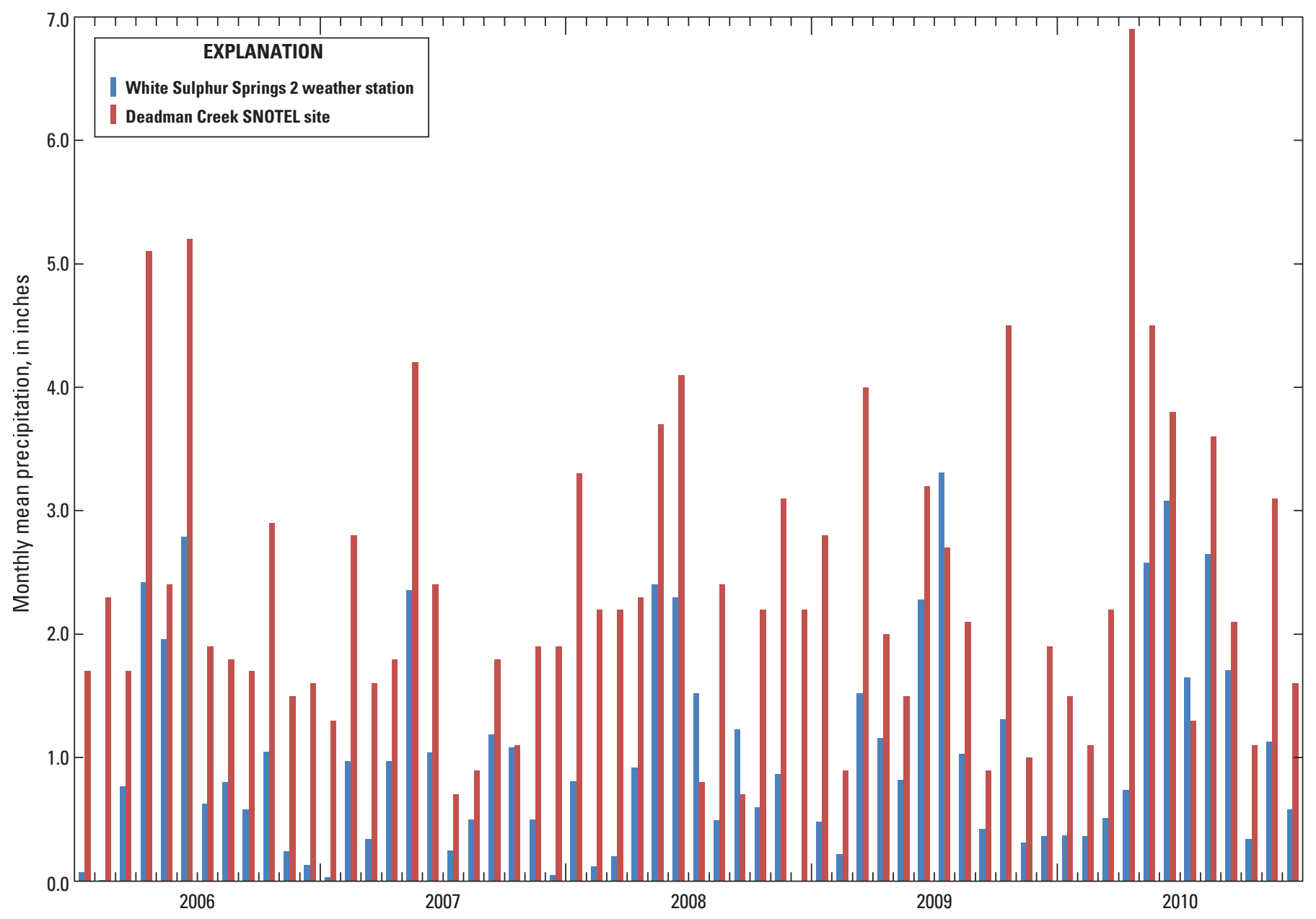

Figure 3. Monthly mean precipitation at White Sulphur Springs and at Deadman Creek in the Little Belt Mountains north of White Sulphur Springs, Montana, 2006-2010. Data from National Weather Service station White Sulphur Springs 2 and the Natural Resources Conservation Service Deadman Creek Snowpack Telemetry (SNOTEL) site.

seepage to streams and drains, and evapotranspiration (ET). ET occurs in the lowlands where the water table is close to land surface in riparian areas with common phreatophytes (such as willows), in flood-irrigated agricultural lands, and in grasslands and pastures.

\section{Surface Water}

Perennial streamflow consists of surface runoff from precipitation and snowmelt and contributions from groundwater, termed base flow. Base flow changes spatially and temporally and is a function of groundwater recharge, ET, aquifer characteristics, groundwater-flow direction, and groundwater withdrawals. Streamflow is also affected by reservoir operation and diversions in the upper watershed. Reservoir and diversion operations may result in augmentation of low flows by releases from storage reservoirs, and dampening of high flows by reservoir storage.
The Smith River originates about $3 \mathrm{mi}$ southwest of White Sulphur Springs at the confluence of the North and South Forks of the Smith River. The North Fork Smith River begins in the Little Belt Mountains to the northwest of White Sulphur Springs and flows for nearly $40 \mathrm{mi}$ to the southwest as it gains flow from tributaries originating in both the Little Belt and the Castle Mountains before joining the South Fork Smith River. The South Fork Smith River begins in the Castle Mountains and flows to the west and northwest for about $38 \mathrm{mi}$. The South Fork Smith River gains flow from tributaries originating from both the Castle and Big Belt Mountains and from an unsealed artesian well near its headwaters. The Smith River flows roughly northwest for about $125 \mathrm{mi}$ until it ultimately joins the Missouri River near Ulm. The upper Smith River meanders extensively, particularly for the first $12 \mathrm{mi}$ above Newlan Creek, where it flows through shallow, entrenched lowlands in gently rolling prairies, agricultural land, and small canyons. Beginning near the mouth of Eagle Creek, about 45 mi downstream from its origin, the Smith River flows 
through steep-sided canyons for nearly $60 \mathrm{mi}$. Major tributaries include Big Birch Creek, Camas Creek, Rock Creek, and Hound Creek from the Big Belt Mountains and Newlan Creek, Sheep Creek, Eagle Creek, and Tenderfoot Creek from the Little Belt Mountains.

Several reservoirs are located in the upper watershed. Most of the reservoirs are small (less than 500 acre-ft), privately owned impoundments (Montana Natural Resource Information System, 2010). The largest reservoirs are Lake Sutherlin (North Fork Smith River Reservoir) and Newlan Creek Reservoir. Lake Sutherlin (14,200 acre-ft capacity) is located about 9 mi northeast of White Sulphur Springs in the upper North Fork Smith River drainage (Montana Natural Resource Information System, 2010). Newlan Creek Reservoir $(15,600$ acre-ft capacity) is located about 6 mi northwest of White Sulphur Springs and collects inflow from upper Newlan Creek including water diverted from Sheep Creek into Newlan Creek (Montana Natural Resource Information System, 2010).

Numerous canals and irrigation ditches traverse the upper watershed, some established in the 1870s. Canals used to transport irrigation and stock water range from short diversions from tributaries to longer systems such as the $15.5 \mathrm{mi}$-long South Side Canal diversion from the North Fork Smith River. A high-resolution hydrography data set (U.S. Geological Survey, 2010) includes approximately $170 \mathrm{mi}$ of canals and ditches in the Smith River watershed, with most (about $96 \mathrm{mi}$ ) located in the upper watershed. Drainage ditches, typically in the valley flats, were constructed to lower the water table to increase arable land for agricultural use. Several of these drainage ditches were observed to flow all year, every year, during the course of this study.

\section{Water Use}

Estimated surface-water and groundwater withdrawals in the Smith River watershed for the year 2000 were approximately 224.54 million gallons per day (Mgal/day) $(252,200$ acre-feet per year (acre-ft/yr); Cannon and Johnson, 2004). Surface water sources supplied most (221.3 Mgal/day) of the water withdrawn. Nearly 99 percent of the water withdrawn was used for the irrigation of 34,650 acres of cropland and pasture (Cannon and Johnson, 2004). Of the water used for irrigation, which is withdrawn intermittently during the growing season from May through September, surface water sources supplied about $220 \mathrm{Mgal} /$ day and groundwater sources supplied the remaining $2.7 \mathrm{Mgal} /$ day.

About 94 percent of the irrigated land in the Smith River watershed is located in the upper part of the watershed, above the Tenderfoot Creek drainage (Montana Department of Natural Resources and Conservation, 2003). About two-thirds of this land is flood irrigated, and the remaining third is irrigated using sprinklers (Montana Department of Natural Resources and Conservation, 2003). The majority of flood irrigation typically occurs during late spring to early summer. Some fields are flood irrigated again in late summer to early fall if water is available. Depending on the crop type, sprinkler irrigation can occur intermittently throughout the growing season (late-spring through summer). Alfalfa is typically irrigated throughout the summer, but suspended for a short period during mid-summer to allow for the first cutting. Approximately 89 percent of irrigated land is used to produce hay (grass and alfalfa) and grain, with the remaining irrigated land used for pasture (Cannon and Johnston, 2004).

\section{Study Design and Approach}

Methods used to study the hydrologic system in the study area and quantify groundwater interaction with surface water included periodic and continuous groundwater-level, streamstage, streamflow, and water-temperature measurement, and two-dimensional heat and solute transport modeling. Measurements were collected from a hydrologic monitoring network that included shallow monitoring wells, existing water-supply wells, deeper exploration wells, long-term USGS streamflowgaging stations, and temporary USGS streamflow-gaging stations. These monitoring sites are uniquely identified according to standard USGS procedures (see appendix 1). Data collected for this study are published in Nilges and Caldwell (2012) along with a detailed description of data collection methods.

Many groundwater and surface-water interaction investigations examine the surface runoff and base-flow components of perennial streamflow. Base flow is commonly determined using hydrograph separation, which differentiates the surfacerunoff component from the groundwater discharge component of streamflow. Direct base-flow estimates are difficult to determine for streams in which the flow is regulated by dams or diversions, which disrupt normal hydrograph recession curves. Base flow estimates were not calculated for the upper Smith River watershed, as flows were likely augmented by releases from storage reservoirs and dampened by reservoir storage.

\section{Groundwater Monitoring}

There are approximately 900 documented water wells in the Smith River watershed as shown in the GWIC database (Montana Bureau of Mines and Geology (MBMG), 2011). The wells are unevenly distributed, with the majority located in the more populated area near White Sulphur Springs and the valley flats, and few if any wells in the foothills and mountains. Throughout 2006, 139 wells were field inventoried for this study (fig. 4). These wells were selected on the basis of spatial distribution, availability of well log records, landowner permission, access, and proximity to the Smith River and its tributaries. The geographic positions of the wells were measured with a handheld global positioning system or with survey-grade Global Positioning System (GPS) survey equipment and Real-Time Kinematic (RTK) positioning. Altitudes of wellheads were also surveyed using survey-grade GPS survey equipment and RTK positioning with estimated accuracy of $+/-0.1 \mathrm{ft}$ or less. 


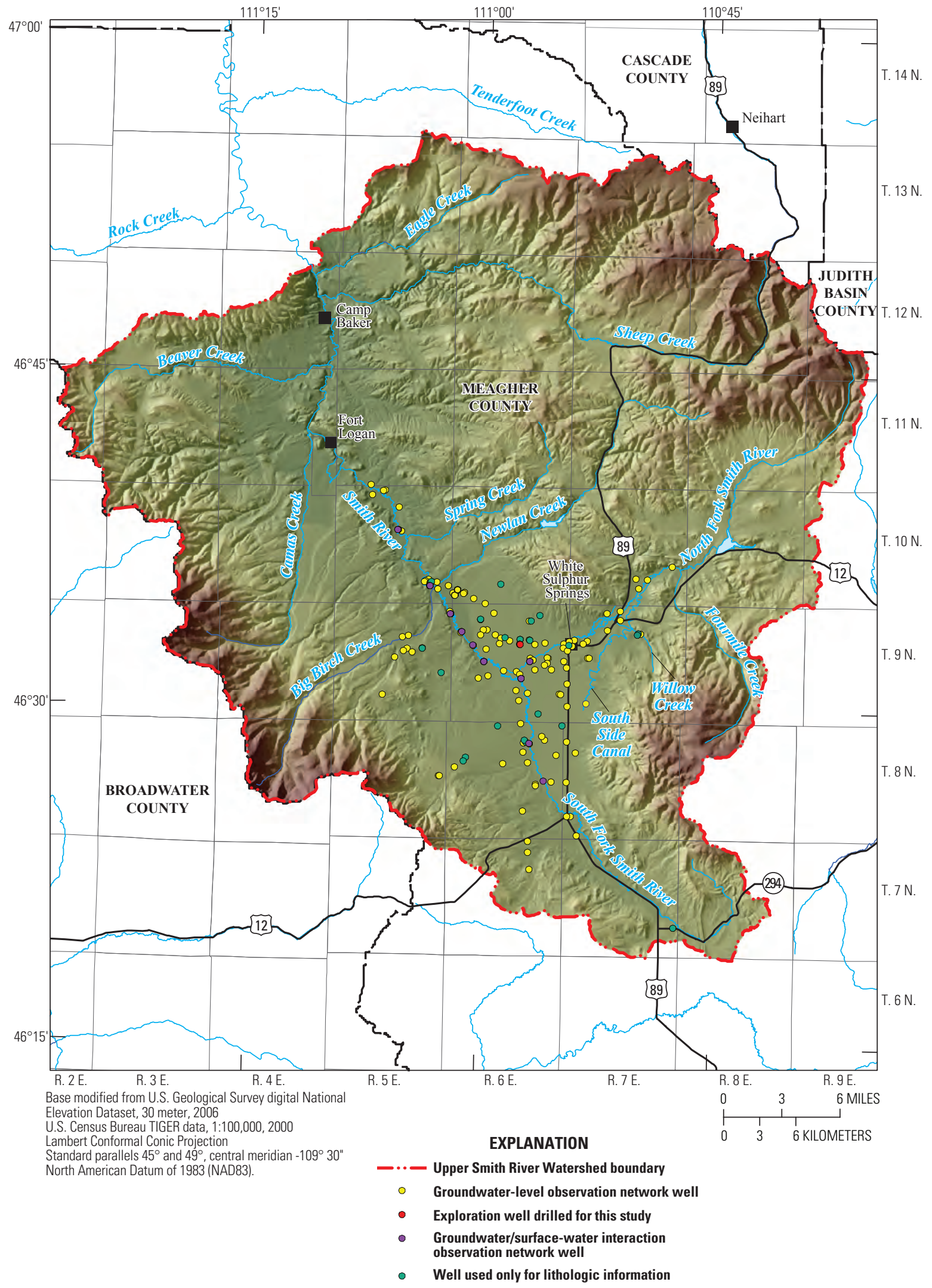

Figure 4. Location of wells used in the study of the upper Smith River watershed, Montana. 
Groundwater-level monitoring provides information on groundwater-level trends and seasonal fluctuations in response to climate, water use, and canal operation. Available groundwater-level data collected by the USGS, MCCD, MDNRC, and the MBMG were utilized during this study (Nilges and Caldwell, 2012). Groundwater-level data include: (1) one-time water levels collected during well inventories, (2) water levels measured in approximately 80 wells on a semi-monthly basis by the USGS and other agencies over various time periods between the early 1990s and 2010, (3) water levels measured continuously by using pressure transducers (see Groundwater and Surface-Water Interaction Monitoring Networks section), and (4) water levels measured synoptically by the USGS in approximately 50 wells in March 2007, August 2007, October 2007, March 2008, and March 2010. The synoptic and semimonthly water-level measurements resulted in a robust data set that was used to create synoptic potentiometric-surface maps. All groundwater-level data utilized for this study are published in Nilges and Caldwell (2012) along with a more detailed description of data-collection methods.

\section{Surface-Water Monitoring}

Streamflow data ranging from miscellaneous measurements to continuous data were measured at 65 sites during this study. All streamflow measurements were made using standard USGS protocols (Rantz and others, 1982; Nolan and Shields, 2000; Turnipseed and Sauer, 2010). Streamflow data for sites within the Smith River watershed are available online through the USGS National Water Information System (NWIS) at http://waterdata.usgs.gov/mt/nwis/.

The USGS operated four long-term streamflow-gaging stations (fig. 1, fig. 5, and table 1) and 13 temporary streamflow-gaging stations (fig. 5 and table 1) during this study. The long-term streamflow gaging stations were operated 4 years or more and were ongoing, newly established, or reestablished during the course of the study. The long-term streamflowgaging stations include the following; (1) Smith River below Newlan Creek near White Sulphur Springs (station number 06076560) at river mile 112.1, (2) Smith River near Fort Logan (station number 06076690) at river mile 83.6, (3) Smith River below Eagle Creek near Fort Logan (station number 06077200) at river mile 80.8, and (4) Smith River near Eden, Montana (station number 06077500) at river mile 27.0 (fig. 1), which is downstream from the upper Smith River watershed.

Temporary streamflow-gaging stations are defined herein as short-term, study-specific staff gages, instrumented with pressure transducers over various time periods. Stage was recorded hourly from April through November during 2007 and 2008 at five of the stations as part of the groundwater and surface-water interaction monitoring network (see Groundwater and Surface-Water Interaction Monitoring Networks section). Six additional temporary, study-specific streamflowgaging stations were installed in 2010 in an effort to estimate tributary inflow in the upper watershed. Stage was recorded hourly at 10 temporary stations during 2010 .

Streamflow was measured periodically at the streamflowgaging stations to create rating curves of streamflow versus stage. Staff gages were surveyed using survey-grade GPS equipment and RTK positioning with estimated accuracy of $+/-0.1 \mathrm{ft}$ or less. Standard differential leveling surveys were conducted annually from 2006 through 2008 and in 2010 in order to examine the magnitude of changes in elevation due to frost heaving.

\section{Synoptic Streamflow Measurements}

Four large-scale synoptic streamflow measurements (seepage runs) were conducted within the upper Smith River watershed (fig. 6, table 2). Streamflow, temperature, and specific conductance measurements were made at up to 45 sites along the Smith River and its tributaries during each of the synoptic streamflow measurements over a short period (less than 8 hours). The timing of the synoptic events was determined by monitoring weather forecasts and real-time streamflow data from USGS gaging stations in an attempt to minimize precipitation and snowmelt effects on streamflow. Rapidly changing streamflow conditions and storm events were avoided.

Synoptic streamflow measurement sites were selected based on aerial photographs, maps, ease of access, and the results of an April 2006 longitudinal survey of the Smith River from the confluence of North and South Forks of the Smith River to just above the mouth of Sheep Creek near Fort Logan (USGS gaging station 06076690). The longitudinal survey included the continuous logging of location from a watercraft using a handheld global positioning system. Temperature and specific conductance measurements of the stream water were simultaneously measured using a self-contained multi-parameter water-quality data logger (an In-situ Inc. multi-parameter TROLL 9500). Locations of observed tributaries and diversions as well as possible groundwater inflow indicated by observed changes in specific conductance and temperature were noted. An effort was made to quantify tributary and groundwater inflows at each of these locations by either measuring streamflow of tributaries at their mouths or by calculating tributary or groundwater inflows by measuring the streamflow in the main stem above and below the tributaries or suspected groundwater inflow.

Three of the synoptic streamflow measurements, on March 22, 2007, October 16, 2007, and April 10, 2008, were selected as periods of nearly stable streamflow with limited irrigation diversions and were used to determine net gains or losses (fig. 7). A fourth measurement, on August 1, 2007, occurred during a period of intense local irrigation and was designed to examine altered flow conditions during an irrigation season. Numerous individual diversions were not measured during the August 1 event; therefore, that synoptic 


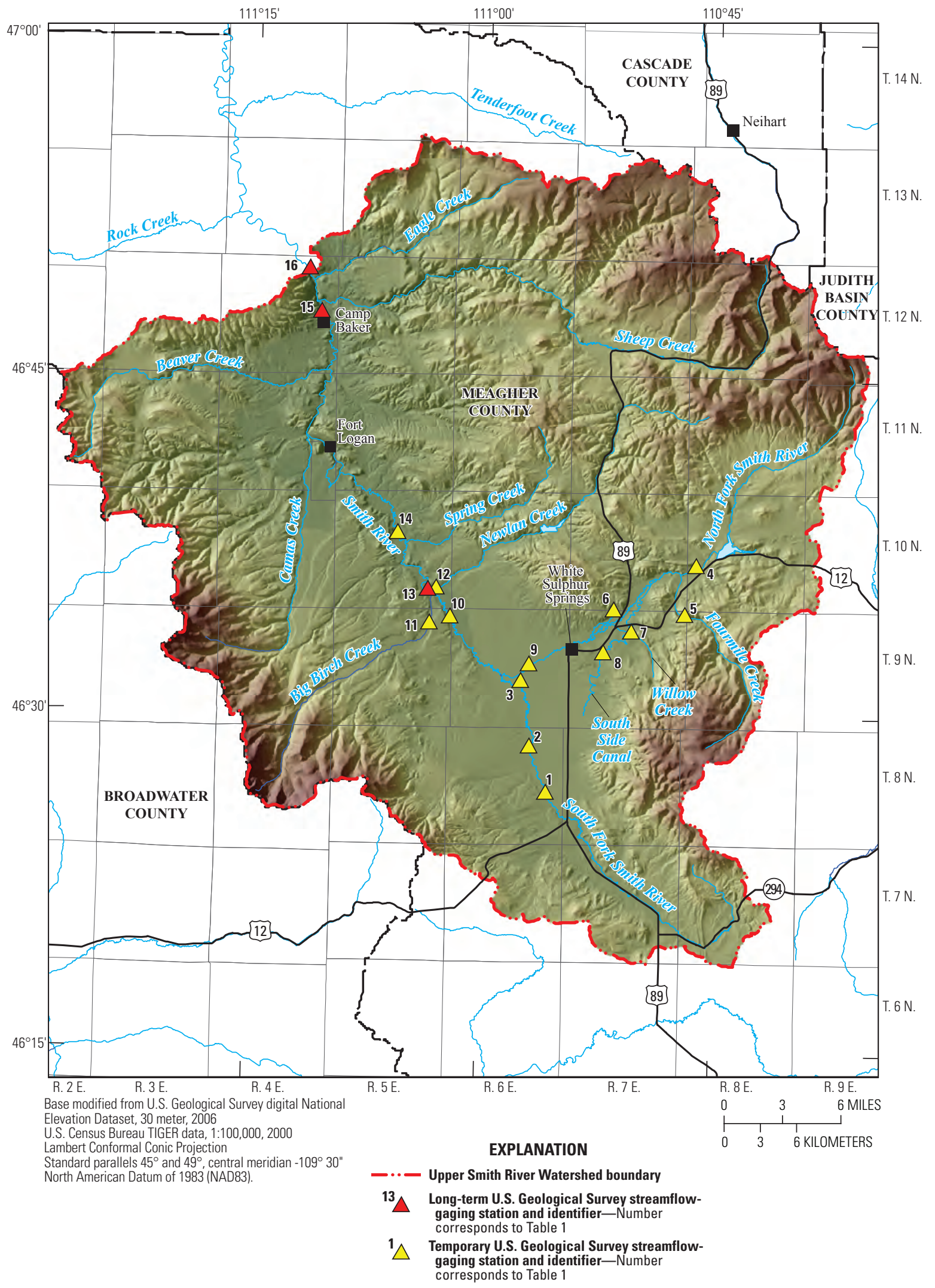

Figure 5. Location of U. S. Geological Survey streamflow-gaging stations in the upper Smith River watershed, Montana. 
Table 1. U.S. Geological Survey streamflow-gaging stations in the Smith River watershed, Montana.

[Map number, used for cross reference for locations plotted on figure 5; Station identification number, see "Site-Identification Systems" section for explanation; Latitude and longitude reported in degrees, minutes, and seconds relative to North American Datum of 1983]

\begin{tabular}{|c|c|c|c|c|c|c|c|c|}
\hline $\begin{array}{c}\text { Map } \\
\text { number } \\
\text { (fig. 5) }\end{array}$ & $\begin{array}{c}\text { Station } \\
\text { identification } \\
\text { number }\end{array}$ & Location description & Latitude & Longitude & $\begin{array}{l}\text { Begin } \\
\text { date }\end{array}$ & End date & $\begin{array}{l}\text { Streamflow } \\
\text { measurement } \\
\text { count }\end{array}$ & 'Station type \\
\hline 1 & 06075775 & $\begin{array}{l}\text { South Fork Smith River at } \\
\text { Birky Road } 1.6 \text { miles below } \\
\text { Cottonwood Creek }\end{array}$ & $46^{\circ} 26^{\prime} 48^{\prime \prime}$ & $110^{\circ} 55^{\prime} 49^{\prime \prime}$ & $3 / 22 / 2007$ & $9 / 24 / 2010$ & 18 & Temporary \\
\hline 2 & 06075780 & $\begin{array}{l}\text { South Fork Smith River } 4.8 \\
\text { miles below Cottonwood } \\
\text { Creek }\end{array}$ & $46^{\circ} 28^{\prime} 30^{\prime \prime}$ & $110^{\circ} 56^{\prime} 47^{\prime \prime}$ & $3 / 22 / 2007$ & $10 / 22 / 2008$ & 9 & Temporary \\
\hline 4 & 463638110460501 & $\begin{array}{l}\text { North Fork Smith River at } \\
\text { Studhorse Road near White } \\
\text { Sulphur Springs, Montana }\end{array}$ & $46^{\circ} 36^{\prime} 38^{\prime \prime}$ & $110^{\circ} 46^{\prime} 08^{\prime \prime}$ & $3 / 19 / 2010$ & $9 / 24 / 2010$ & 11 & Temporary \\
\hline 7 & 463340110501401 & $\begin{array}{l}\text { Willow Creek at South Side } \\
\text { Canal near White Sulphur } \\
\text { Springs, Montana }\end{array}$ & $46^{\circ} 33^{\prime} 40^{\prime \prime}$ & $110^{\circ} 50^{\prime} 17^{\prime \prime}$ & $3 / 23 / 2010$ & $10 / 8 / 2010$ & 14 & Temporary \\
\hline 8 & 463242110520101 & $\begin{array}{l}\text { South Side Canal at Willow } \\
\text { Creek near White Sulphur } \\
\text { Springs, Montana }\end{array}$ & $46^{\circ} 32^{\prime} 42^{\prime \prime}$ & $110^{\circ} 52^{\prime} 04^{\prime \prime}$ & $6 / 29 / 2010$ & $10 / 8 / 2010$ & 5 & Temporary \\
\hline 9 & 06075700 & $\begin{array}{l}\text { North Fork Smith River near } \\
\text { mouth near White Sulphur } \\
\text { Springs, Montana }\end{array}$ & $46^{\circ} 32^{\prime} 09^{\prime \prime}$ & $110^{\circ} 56^{\prime} 52^{\prime \prime}$ & $1 / 13 / 1993$ & $7 / 30 / 2010$ & 50 & Temporary \\
\hline 10 & 06075850 & $\begin{array}{l}\text { Smith River above Mud Springs } \\
\text { Creek }\end{array}$ & $46^{\circ} 34^{\prime} 14^{\prime \prime}$ & $111^{\circ} 02^{\prime} 02^{\prime \prime}$ & $3 / 22 / 2007$ & $10 / 22 / 2008$ & 8 & Temporary \\
\hline 13 & 06076560 & $\begin{array}{l}\text { Smith River below Newlan } \\
\text { Creek near White Sulphur } \\
\text { Springs, Montana }\end{array}$ & $46^{\circ} 35^{\prime} 27^{\prime \prime}$ & $111^{\circ} 03^{\prime} 29^{\prime \prime}$ & $9 / 23 / 2004$ & $12 / 16 / 2010$ & 71 & Long term \\
\hline 14 & 06076580 & $\begin{array}{l}\text { Smith River above Rock } \\
\text { Springs Creek }\end{array}$ & $46^{\circ} 37^{\prime} 57^{\prime \prime}$ & $111^{\circ} 05^{\prime} 30^{\prime \prime}$ & $9 / 14 / 2006$ & $10 / 23 / 2008$ & 9 & Temporary \\
\hline 15 & 06076690 & $\begin{array}{l}\text { Smith River near Fort Logan, } \\
\text { Montana }\end{array}$ & $46^{\circ} 47^{\prime} 45^{\prime \prime}$ & $111^{\circ} 10^{\prime} 44^{\prime \prime}$ & 9/23/1977 & $10 / 28 / 2010$ & 275 & Long term \\
\hline 16 & 06077200 & $\begin{array}{l}\text { Smith River below Eagle Creek } \\
\text { near Fort Logan, Montana }\end{array}$ & $46^{\circ} 49^{\prime} 41^{\prime \prime}$ & $111^{\circ} 11^{\prime} 32^{\prime \prime}$ & 8/1/1996 & $12 / 16 / 2010$ & 145 & Long term \\
\hline $\begin{array}{l}\text { See } \\
\quad \text { fig.1. }\end{array}$ & 06077500 & $\begin{array}{l}\text { Smith River near Eden, } \\
\text { Montana }\end{array}$ & $47^{\circ} 11^{\prime} 21^{\prime \prime}$ & $111^{\circ} 23^{\prime} 11^{\prime \prime}$ & $8 / 4 / 1988$ & $12 / 9 / 2010$ & 53 & Long term \\
\hline
\end{tabular}

${ }^{1}$ Temporary, streamflow-gaging station operated less than 4 years over various time periods; long term, streamflow-gaging station operated 4 years or more. 


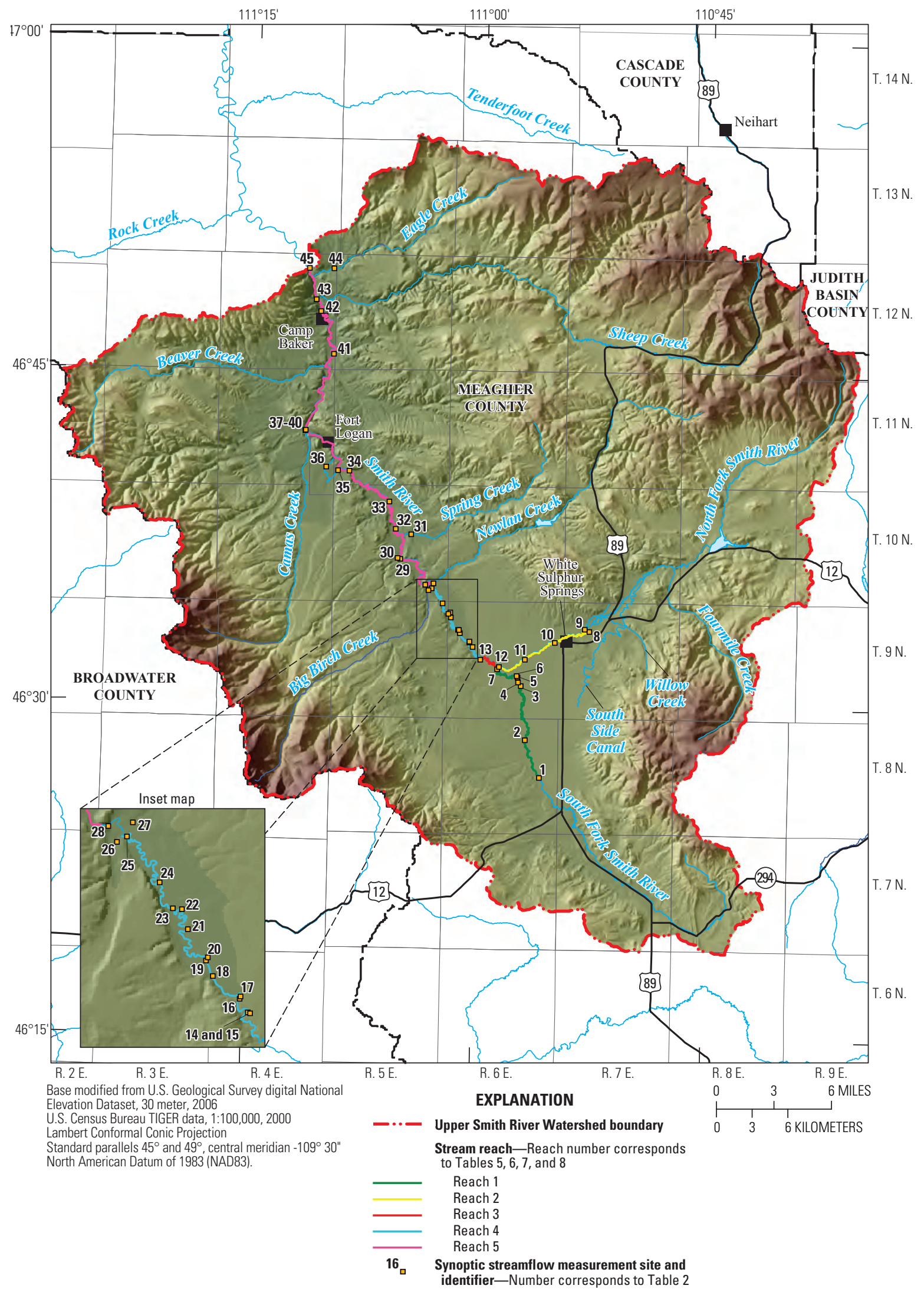

Figure 6. Location of synoptic streamflow measurement sites in the upper Smith River watershed, Montana. 
Table 2. Site descriptions and locations for synoptic streamflow measurements in the upper Smith River watershed, Montana.

[Map number, used for cross reference for locations plotted on figure 6; Station identification number, see "Site-Identification Systems" section for explanation; River mile, distance above mouth; Latitude and longitude reported in degrees, minutes, and seconds referenced to North American Datum of 1983; main stem South Fork Smith River, North Fork Smith River, and Smith River stations in bold type]

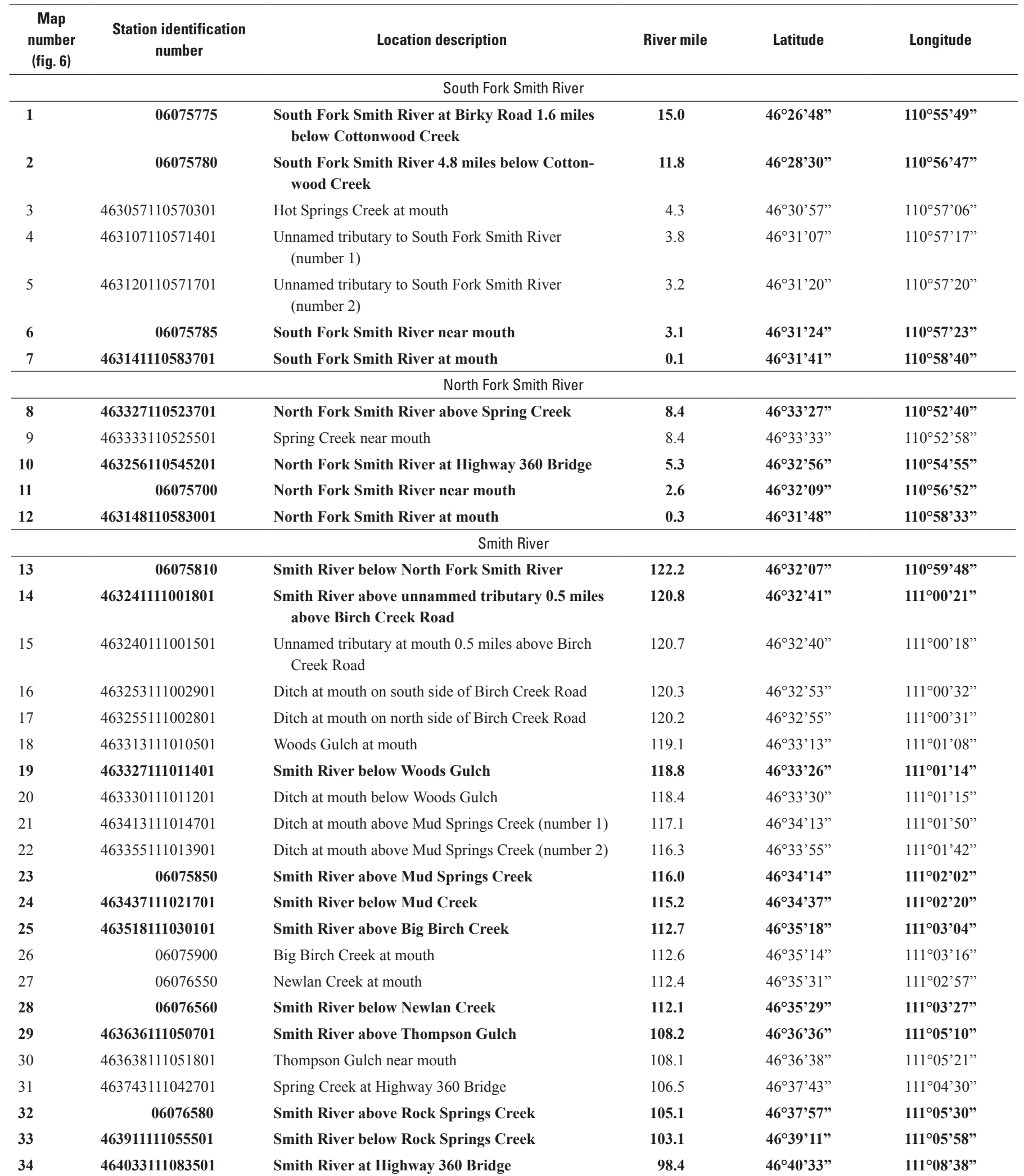


Table 2. Site descriptions and locations for synoptic streamflow measurements in the upper Smith River watershed, Montana.Continued

[Map number, used for cross reference for locations plotted on figure 6; Station identification number, see "Site-Identification Systems" section for explanation; River mile, distance above mouth; Latitude and longitude reported in degrees, minutes, and seconds referenced to North American Datum of 1983; main stem South Fork Smith River, North Fork Smith River, and Smith River stations in bold type]

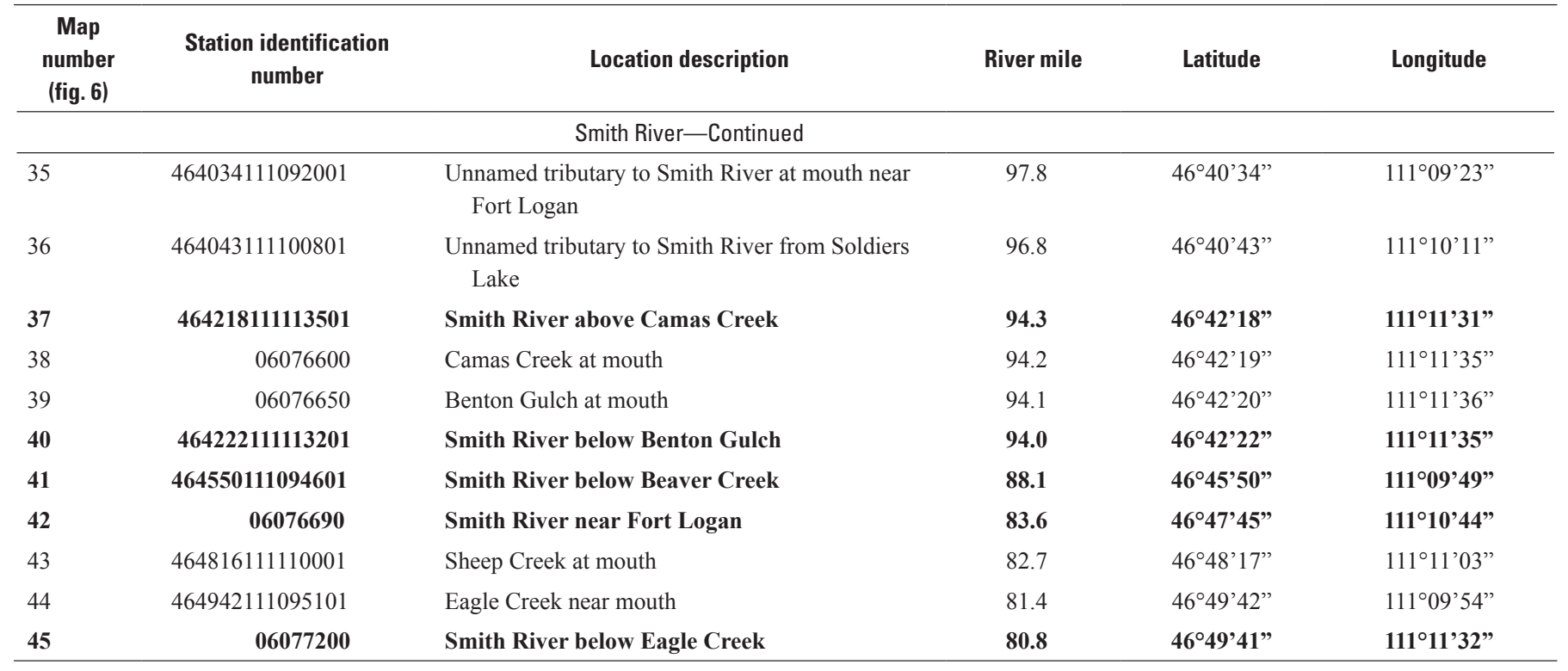

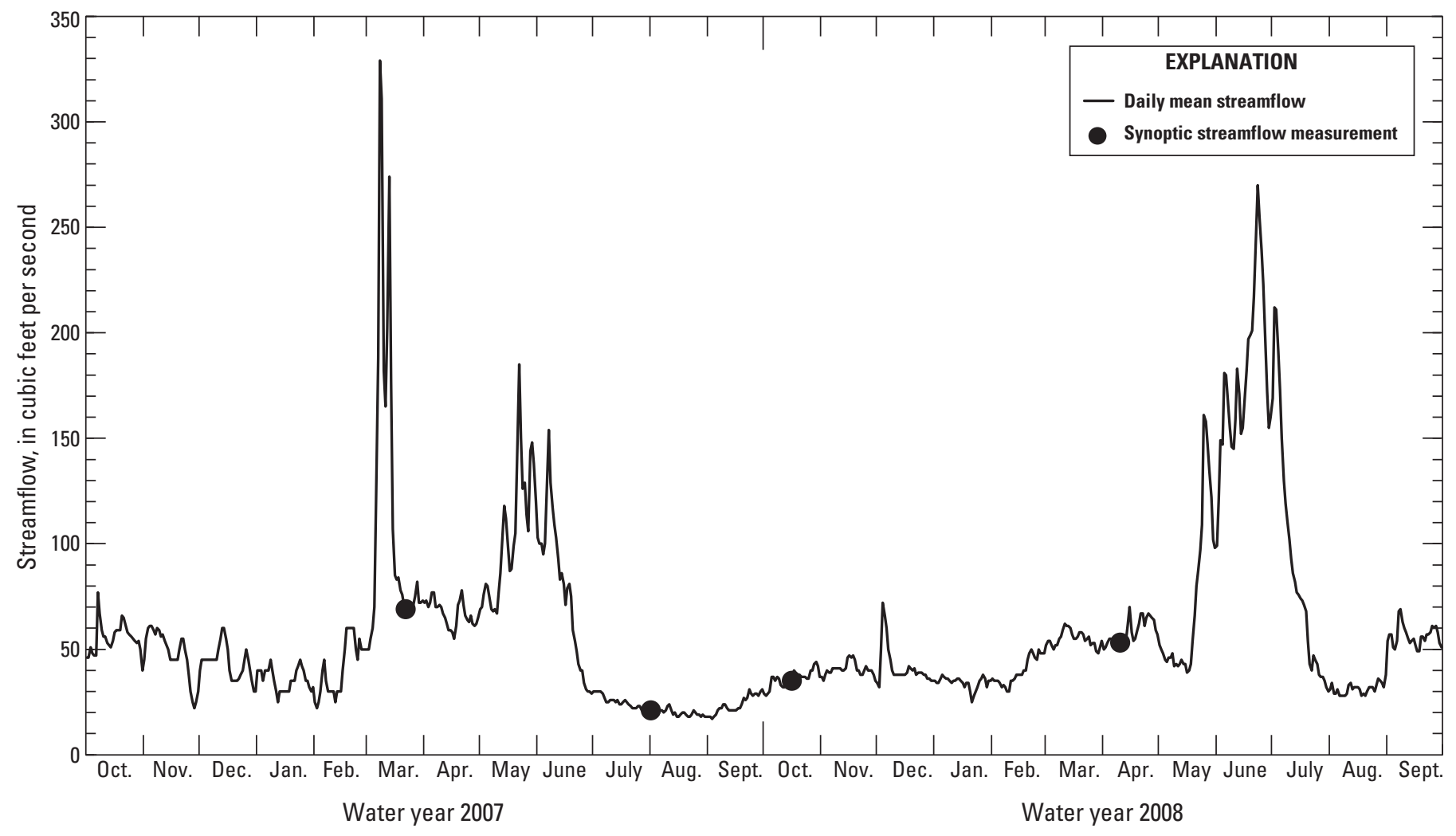

Month

Figure 7. Daily mean streamflow at the Smith River below Newlan Creek near White Sulphur Springs, Montana U.S. Geological Survey streamflow-gaging station (station 06076560) and corresponding synoptic streamflow measurement dates, water years 2007 and 2008. 
measurement cannot be used with confidence for gain/loss estimates.

The resulting gain or loss computed between measuring points during a synoptic streamflow measurement is an estimate of the net rate of water exchange between the surface water and the groundwater, averaged over the length of a specified reach. The volume of water gained or lost by the stream during each synoptic measurement was calculated as follows:

Net seepage gain or loss $=Q d-T-Q u+D$

Where

$$
\begin{aligned}
Q d= & \text { streamflow at the downstream end of a reach, } \\
& \text { in cubic feet per second } \\
T= & \text { sum of all tributary inflows within a reach, in } \\
& \text { cubic feet per second } \\
Q u= & \text { streamflow at the upstream end of a reach, } \\
& \text { in cubic feet per second } \\
D= & \text { sum of all diversion outflows within a reach, in } \\
& \text { cubic feet per second }
\end{aligned}
$$

The calculated value of each gain or loss has a level of uncertainty that is associated with each streamflow measurement. This uncertainty in streamflow measurements, also known as measurement error, standard error, or indeterminate error, results from inherent inaccuracies associated with the equipment and techniques used during each streamflow measurement. Sources of these uncertainties in USGS streamflow measurements have been analyzed and a rating system has been developed to estimate this measurement error for individual streamflow measurements (Sauer and Meyer, 1992). The rating system used in this investigation to estimate measurement error for each streamflow measurement is as follows: good with measured streamflow within 5 percent of actual streamflow ( 5 percent used in calculations); fair with measured streamflow within 5 to 8 percent of actual streamflow ( 8 percent used in calculations); and poor with measured streamflow 8 percent or greater of the actual streamflow (10 percent used in calculations). Estimated error associated with each calculated gain or loss value was determined by using the flowing propagation of error formula:

$$
s=\sqrt{( \pm \mathrm{a})^{2}+( \pm \mathrm{b})^{2}+( \pm \mathrm{n})^{2}}
$$

Where

$s \quad$ is the error propagated from all estimated individual measurement errors and $\mathrm{a}, \mathrm{b}, \mathrm{n}$ are the estimated errors for the streamflow measurement at each site.

\section{Groundwater and Surface-Water Interaction Monitoring Networks}

The groundwater and surface-water interaction monitoring networks, each with one to five monitoring wells (31 total), were installed during 2006 and 2007 at 10 sites along the North and South Forks of the Smith River and the Smith River. Sites corresponded either with staff gages installed for this study or an existing streamflow-gaging station (table 3 , fig. 8). Since all of the groundwater and surface-water network sites were located in low-lying areas adjacent to streams, nearly all sites were in areas with nearby flood irrigation. Five sites with 1 to 3 wells were designed to determine the general groundwater and surface-water flow direction, whereas five sites with 4 or 5 wells were designed to also estimate the hydraulic characteristics of the near-stream Quaternary alluvium and water flux (amount of water flowing between the groundwater and stream, see Monitoring and Modeling of Heat Transport section). Wells at each site were installed along a cross section perpendicular to the stream. Sites with one to three wells typically had wells installed within the stream approximately $2.5 \mathrm{ft}$ from the stream bank. A typical cross section at sites with four to five wells had wells installed on both stream banks approximately $2.5 \mathrm{ft}$ from the water's edge, and wells installed within the stream approximately $2.5 \mathrm{ft}$ from each stream bank (fig. 9). Deeper wells were installed within the stream at three sites to examine the relation of head (water level) to depth. In some cases, data from nearby existing monitoring wells or water-supply wells were also available. The area representing the stream banks, which is typically unsaturated, was generalized and designated as soil for this study. All data collected at the groundwater and surface-water interaction monitoring networks used for this study are published in Nilges and Caldwell (2012) along with a more detailed description of data collection methods.

\section{Monitoring and Modeling of Heat Transport}

The use of heat as a tracer in conjunction with stage and groundwater-level measurements has proven to be an effective method for estimating groundwater and surfacewater exchange at the streambed interface (Constantz and Stonestrom, 2003; Constantz, 2008; Essaid and others, 2008; Eddy-Miller and others, 2009). Water temperatures in area streams typically range from 0 to about $25^{\circ} \mathrm{C}$ annually and can vary several degrees on a daily basis due to variations in air temperature (Nilges and Caldwell, 2012). Typically, groundwater is insulated from the daily air-temperature variation and groundwater temperature therefore remains fairly constant. Heat is transported continuously between the stream, 


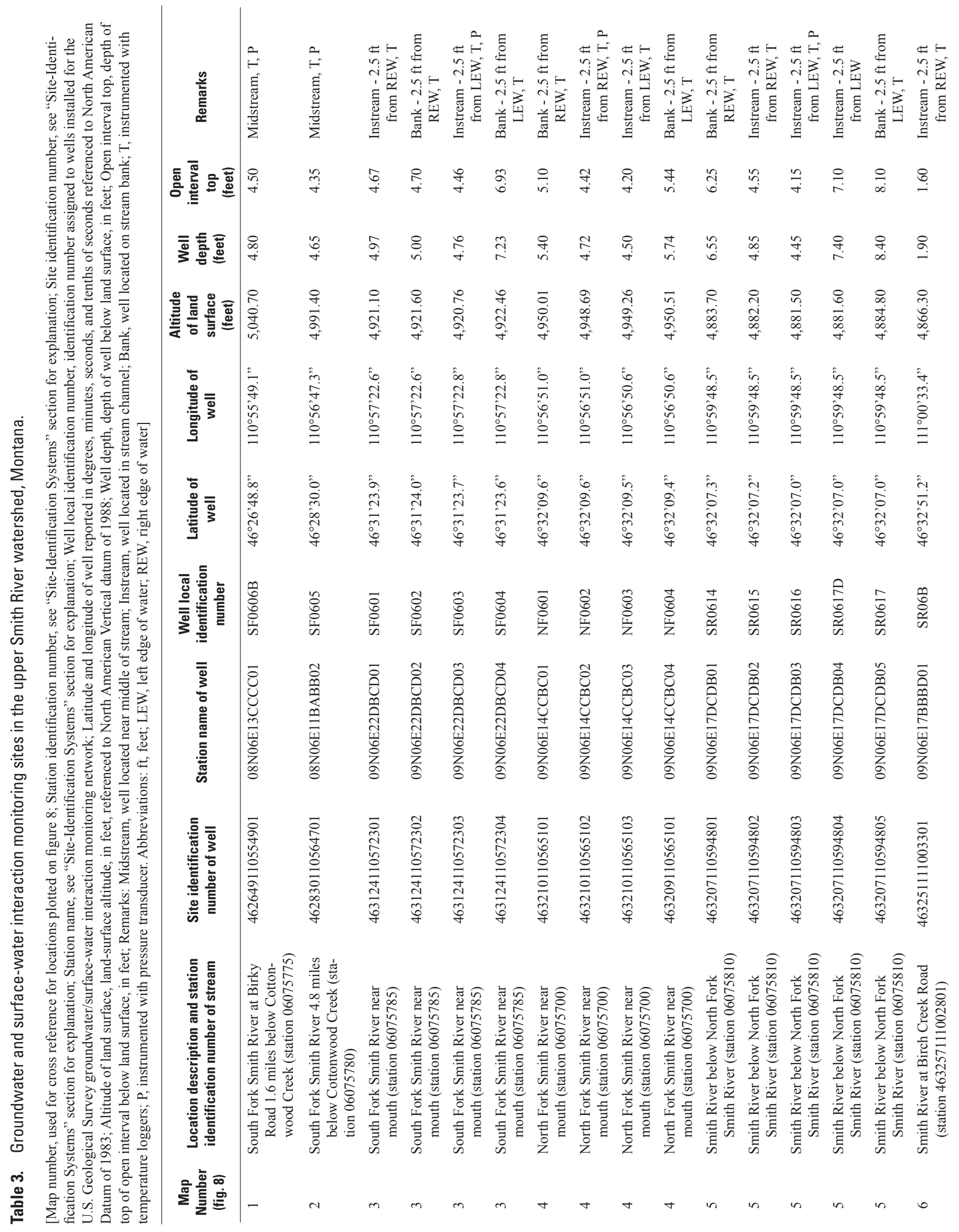




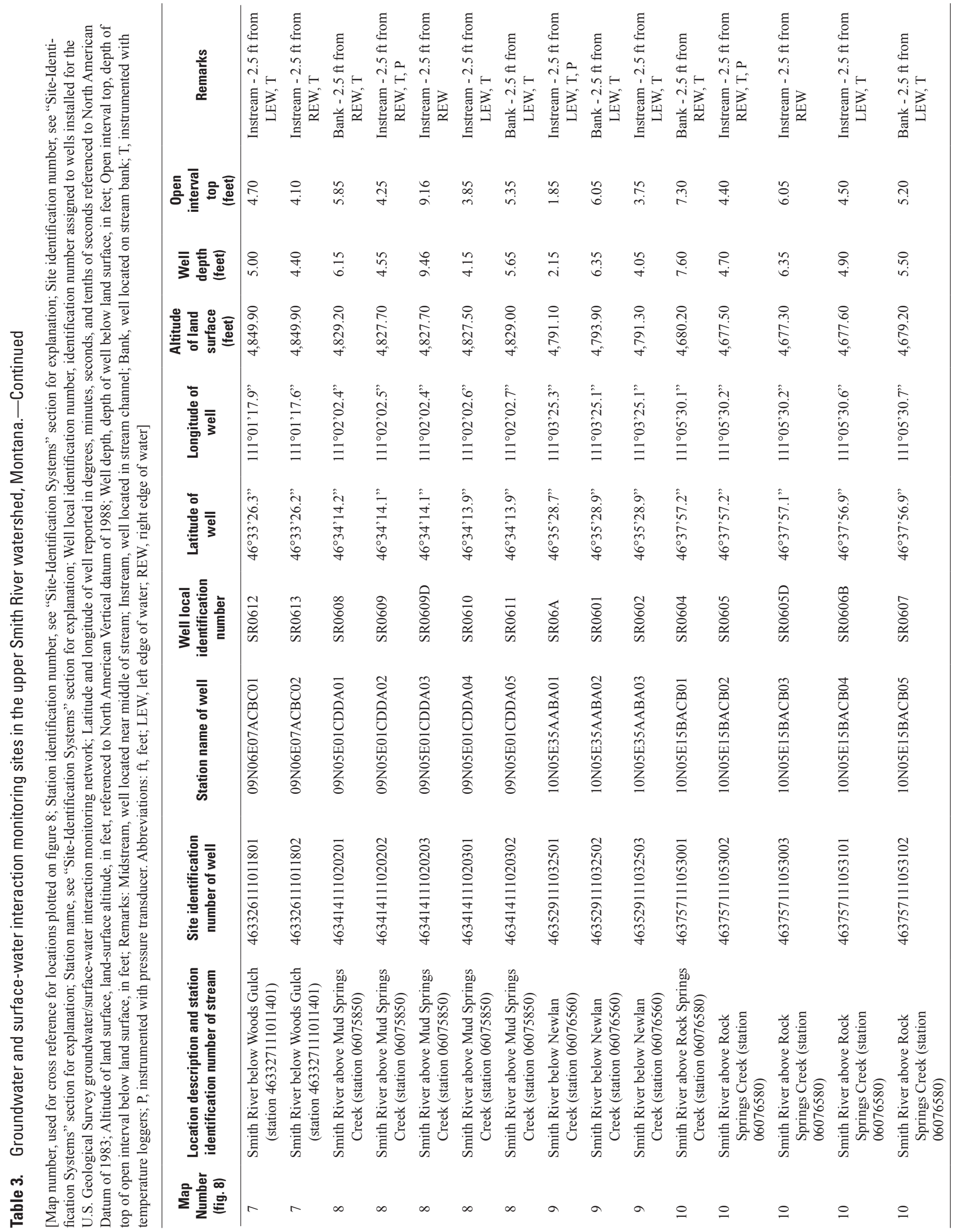




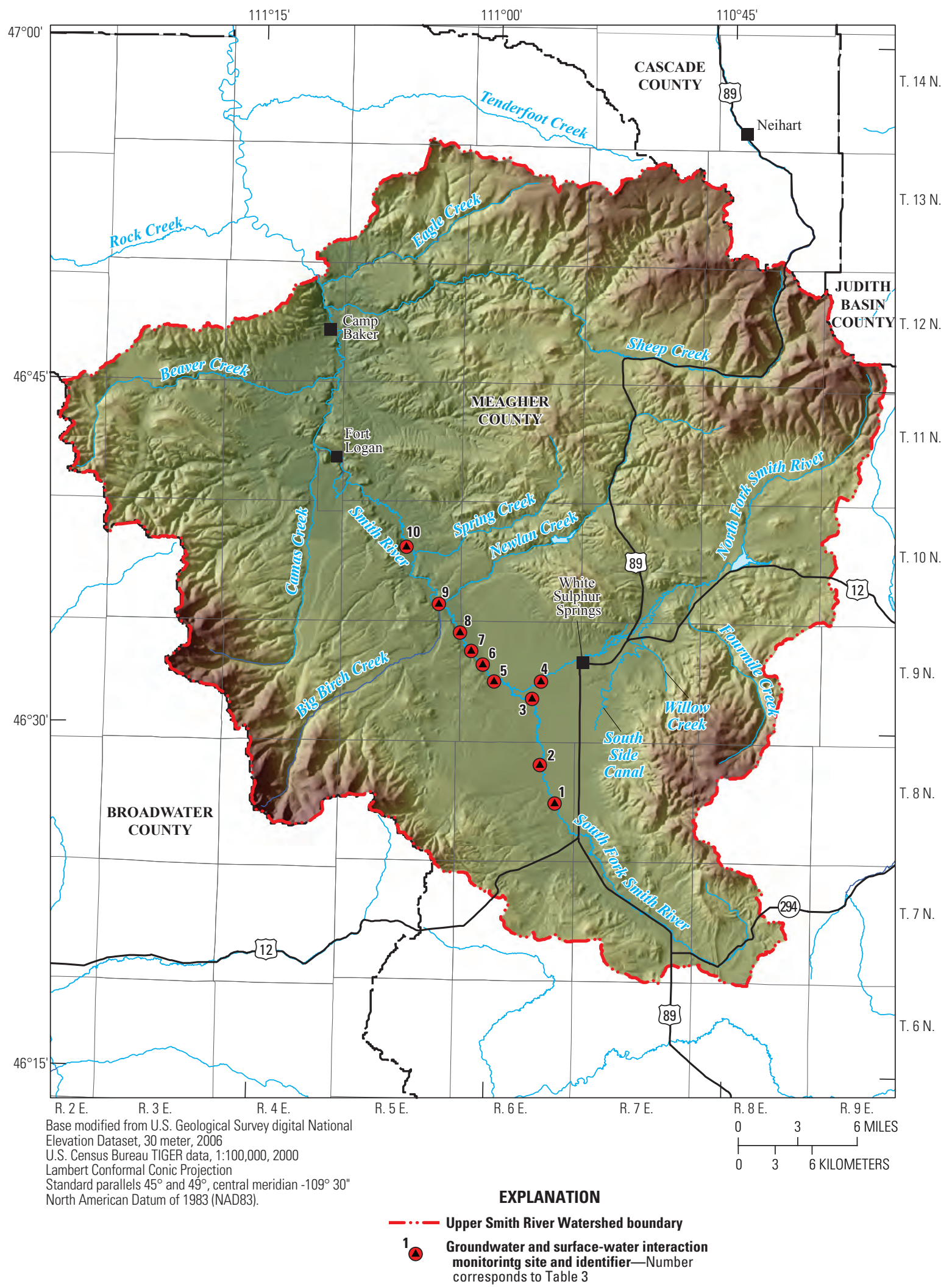

Figure 8. Location of groundwater and surface-water interaction monitoring sites in the upper Smith River watershed, Montana. 


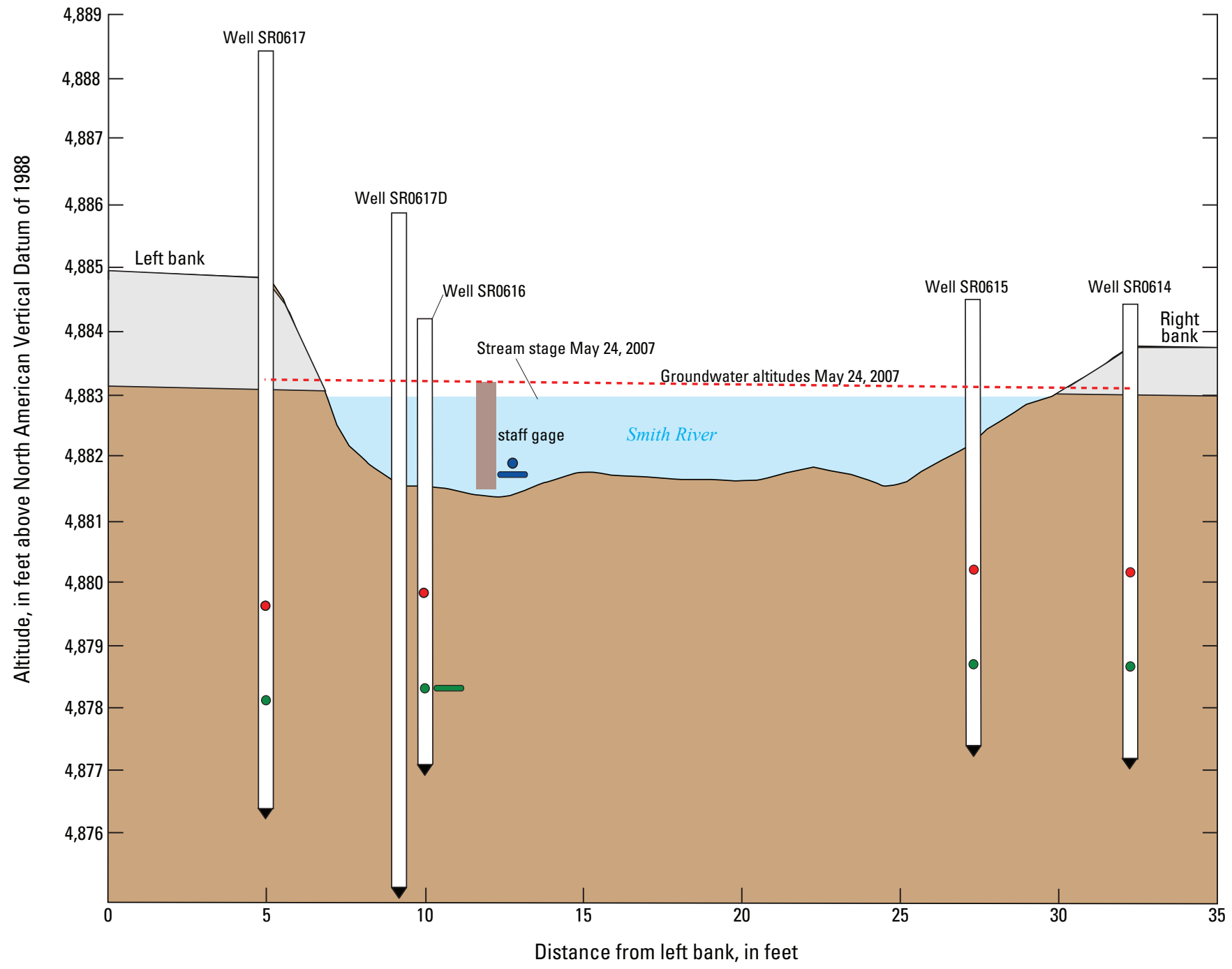

EXPLANATION

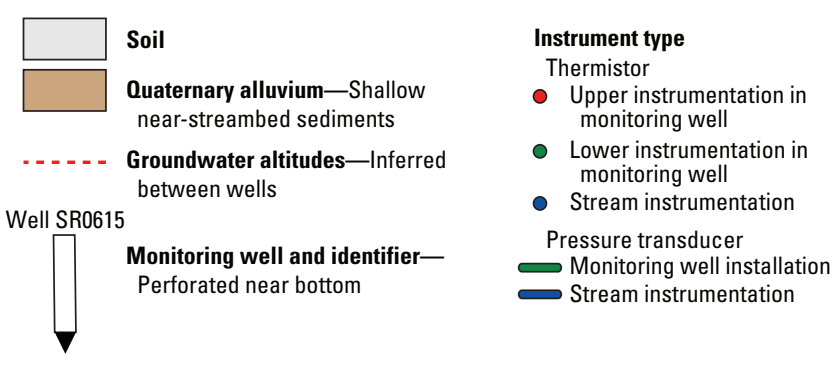

Figure 9. Channel geometry, monitoring well network, and thermistor and/or pressure transducer locations at the Smith River below North Fork Smith River monitoring site (station 06075810). Groundwater altitudes and stream stage for May 24, 2007. 
underlying sediments, and adjacent groundwater (Constantz, 2008). Whenever a difference in temperature exists between two points along a groundwater flow path, heat will be predominantly transported along with the moving groundwater (advective heat flow) and to a lesser extent by the conduction of heat (conductive heat flow) through the underlying streambed and aquifer material and water trapped between the fine sediment (Constantz and Stonestrom, 2003). In the case of a gaining stream reach (where groundwater is discharged to the stream through the streambed), the upward advection of heat due to the higher head in the groundwater is coupled with the downward conduction of heat via the streambed sediments (fig.10A). This combination of heat transport dampens the diurnal and seasonal temperature cycle seen in the stream water and attenuates the timing of the peaks and valleys of the thermal signal. In a losing stream reach (where surface water is discharged to the aquifer through the streambed), heat is transported downward by both conduction and advection. These two mechanisms of heat transport together create a thermal signal in the groundwater that shows more diel fluctuation (fig. 10B) than observed in the groundwater adjacent to a gaining stream reach (fig. 10A).

The method requires continuous stream temperature, stream stage, groundwater temperature at multiple depths below the streambed, and groundwater levels at the modeled streambed cross sections (Eddy-Miller and others, 2009). At modeled sites, data loggers recorded continuous (hourly) stream stage, groundwater levels in a single well, and temperature in the stream and at two depths in four monitoring wells (approximately $1.5 \mathrm{ft}$ and $3.0 \mathrm{ft}$ below the streambed) representing the sediment below the stream. Daily mean groundwater levels at each well within a modeled cross section, derived from hourly water levels, were required for model input. In order to construct a data set of hourly groundwater levels for the wells lacking continuous data, linear regressions were developed between the manual groundwater-level measurements of the well with hourly data and each of the other wells. These linear relations were used to estimate hourly groundwater levels for the three wells lacking continuous data. The hourly groundwater-level, stream-stage, and temperature data were then averaged to determine daily mean values.

The hydraulic conductivity of the Quaternary alluvium and water flux (flow or exchange) were quantitatively estimated using the two-dimensional groundwater heat and solute transport model VS2DH (Healy and Ronan, 1996; Healy, 2008) and the graphical user interface VS2DI (Hsieh and others, 2000). The VS2DH model simulates the (advective and conductive) flow of heat through sediments to determine the hydraulic conductivity. The general modeling approach was similar to Eddy-Miller and others (2009). Models were developed for three stream cross sections on the basis of field surveys of channel geometry, stream stage, groundwater level, and temperature data. Detailed descriptions of the selected cross-section models constructed for this study are included in appendix 2 .
The computer-model simulations were conducted using a range of vertical and horizontal conductivity values of the Quaternary alluvium, hydraulic conductivity of the unsaturated soil on the stream bank, typical values of porosity, dispersivity, heat capacity of the Quaternary alluvium, and heat capacity of water based on published values (Freeze and Cherry, 1979; Niswonger and Prudic, 2003). When available, the cross-section models were developed using data collected in a single field season (2007 or 2008). The developed model was then run using data from a second season to determine if the same parameters would yield output of simulated versus observed data within acceptable errors. The results of each model simulation were reviewed by comparing observed (measured) temperature data with the model results (simulated temperature at that location within the model). Hydraulic properties were adjusted until the simulated temperature values reasonably matched observed values (the best-fit model).

The flow of water (water flux) across the streambed, bottom, and side boundaries of the cross-section models was calculated using results of the calibrated 2-D water heat and solute transport VS2DH models (app. 3). Water flux calculated for each boundary represents the amount of water that flowed across the entire length of each boundary over a unit (1-ft) width. Modeled results of water-flux output were compared with the synoptic streamflow data and records from stagestreamflow relations at several locations.

\section{Surface-Water System}

Continuous streamflow monitoring on the Smith River and major tributaries allowed for a better understanding of the combined influence of tributary contributions, reservoir operation, diversions, return flow, and groundwater interaction through different parts of the watershed. This study marked the first time (water years 2006 through 2010) that four concurrent long-term streamflow-gaging stations were in operation on the Smith River (table 1). In addition, manual streamflow measurements and computed daily streamflow data were available for 13 temporary streamflow-gaging stations on the Smith River and selected tributaries (table 1) which allowed for further spatial definition of the surface-water system.

\section{Streamflow at Long-Term USGS Streamflow- Gaging Stations}

A review of computed daily streamflow at the four longterm USGS streamflow-gaging stations on the Smith River showed similar trends with high flows typically occurring in the spring to early summer and more stable, moderate to low flows occurring from mid-summer through early spring. Streamflow typically increased in a downstream direction, primarily due to additional tributary contribution and net groundwater inflow (fig. 11). The most upstream streamflow-gaging station on the Smith River, the Smith River below Newlan 


\section{A. Gaining reach of stream}

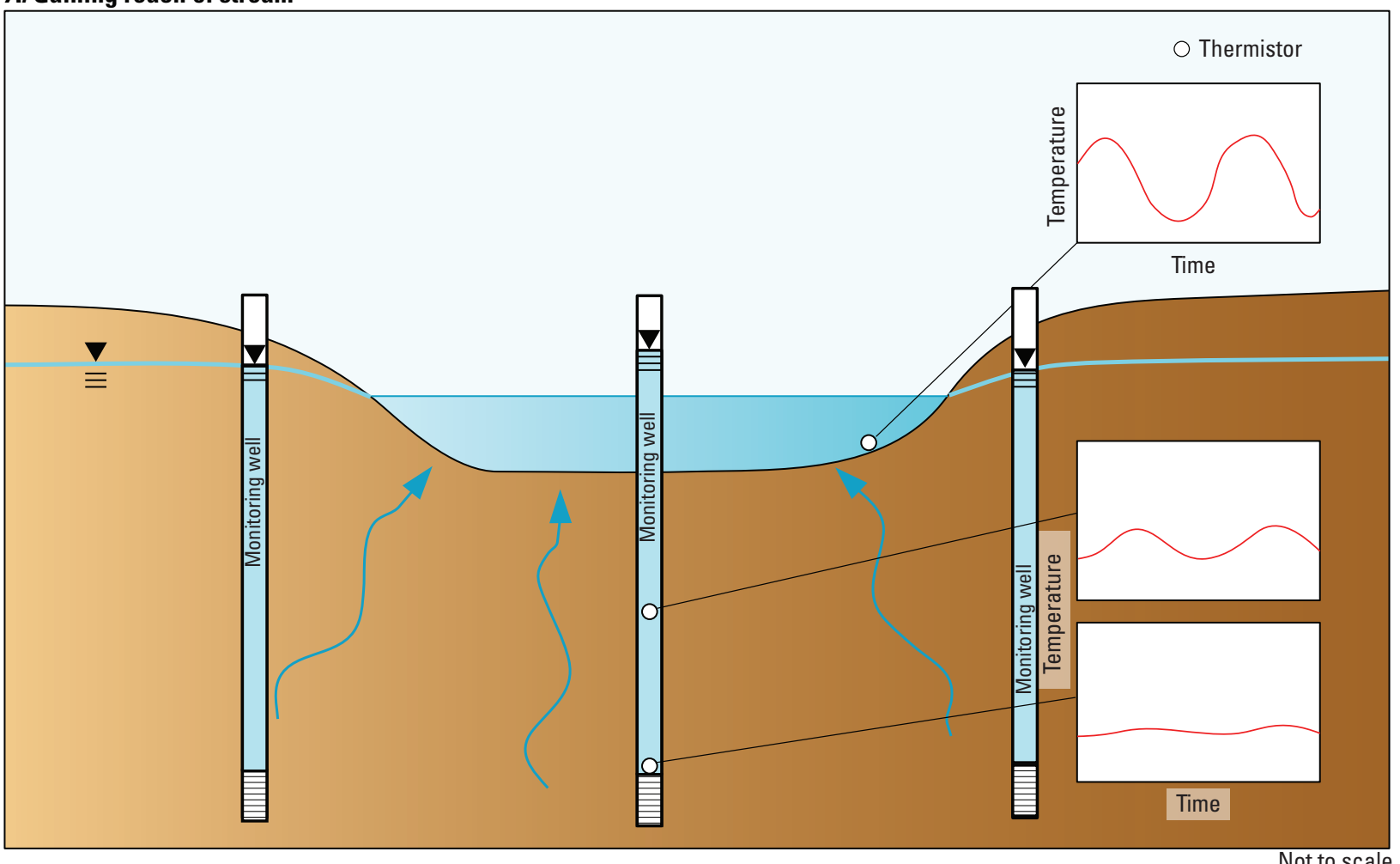

\section{B. Losing reach of stream}

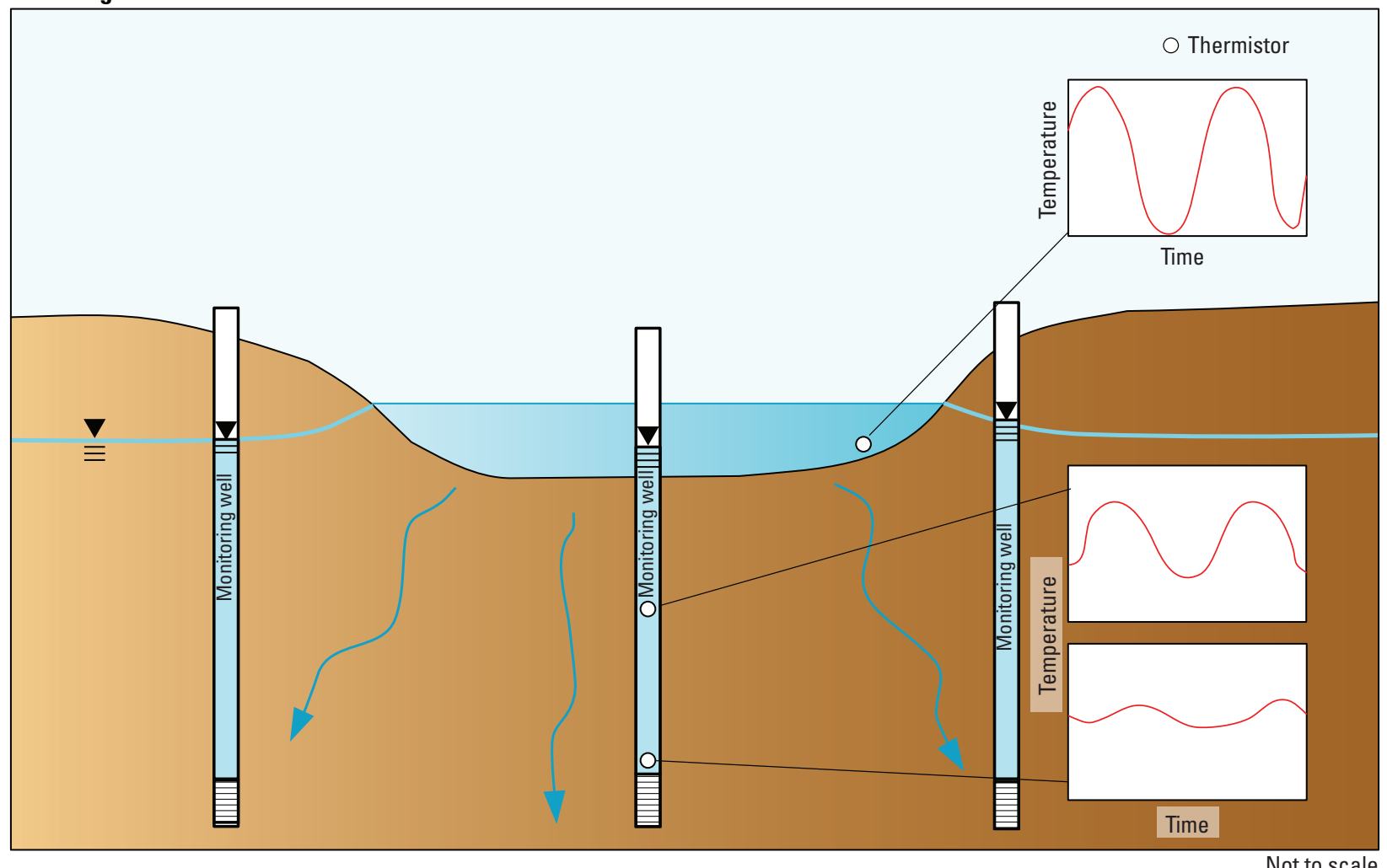

Figure 10. Streambed flow and heat transport in a gaining and a losing stream; $A$, Gaining reach. $B$, Losing reach. (Schematics modified from Constantz and Stonestrom, 2003). 


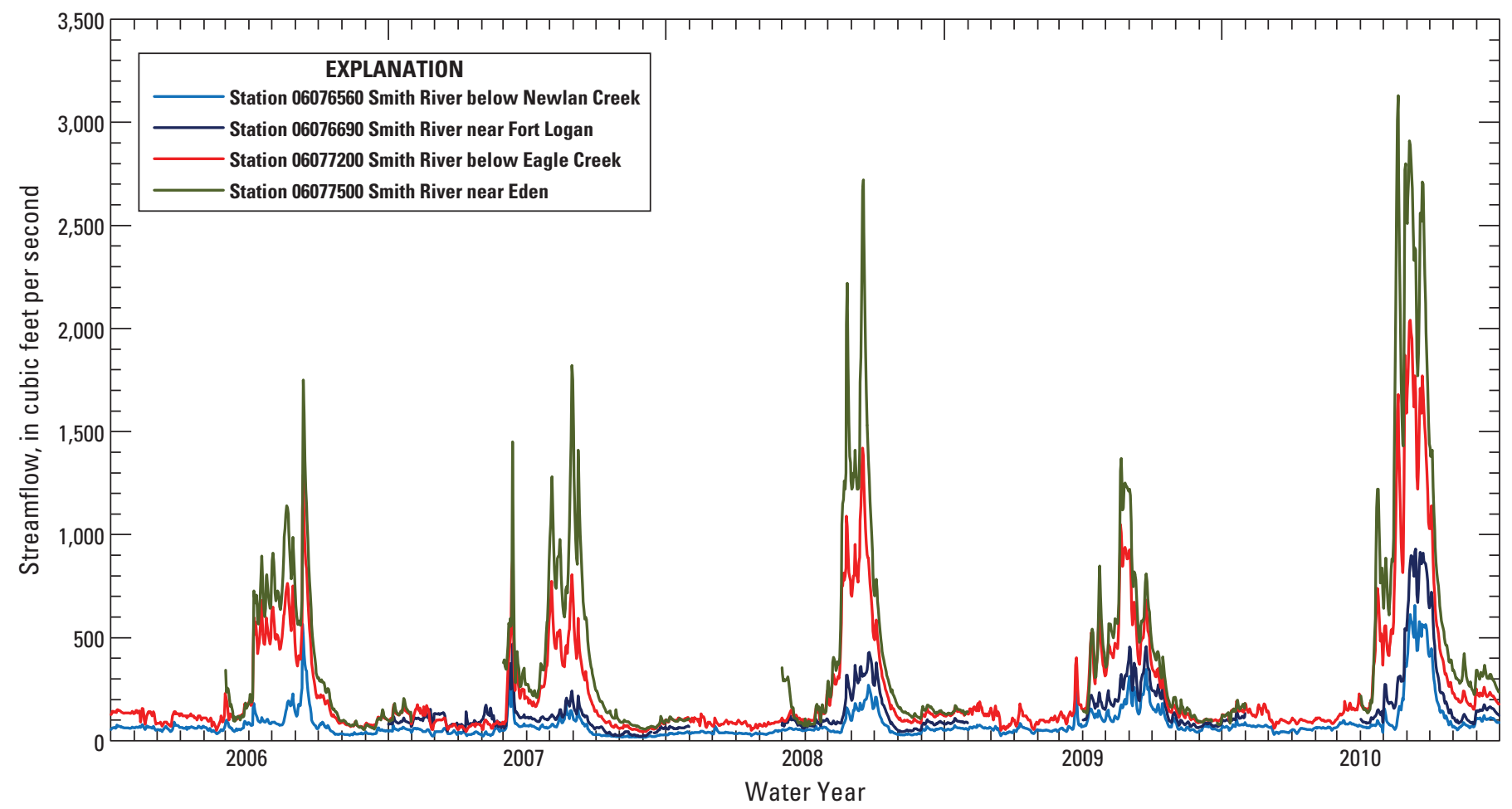

Figure 11. Computed daily streamflow at U.S. Geological Survey Smith River streamflow-gaging stations on the Smith River for water years 2006 through 2010.

Creek gage (station number 06076560), includes contributions from upstream tributaries including the North Fork Smith River, South Fork Smith River, Birch Creek, and Newlan Creek and is partly regulated by Lake Sutherlin and by Newlan Creek Reservoir. The average annual streamflow for water years 2005-2010 was 80.9 cubic feet per second $\left(\mathrm{ft}^{3} / \mathrm{s}\right)$ with daily streamflow ranging from $17 \mathrm{ft}^{3} / \mathrm{s}$ (September 3 , 2007) to $656 \mathrm{ft}^{3} / \mathrm{s}$ (June 11, 2010). Another streamflowgaging station with continuous record for water years 20052010, the Smith River below Eagle Creek near Fort Logan gage (station number 06077200), is located about $31 \mathrm{mi}$ downstream from the Smith River below Newlan Creek gage and includes contributions from Camas Creek, Benton Gulch, Beaver Creek, Whitetail Creek, Sheep Creek, and Eagle Creek. Average annual streamflow was $244 \mathrm{ft}^{3} / \mathrm{s}$ (water years 2005-10) with daily streamflow ranging from $43 \mathrm{ft}^{3} / \mathrm{s}$ (August 31,2007 ) to $2,040 \mathrm{ft}^{3} / \mathrm{s}$ (June 5, 2010).

A review of streamflow statistics indicated that streamflow conditions during this study (2006-2010) were typical of the range of streamflow conditions expected long term. The average annual streamflow at Smith River below Eagle Creek streamflow-gaging station (station number 06077200), the longest continuously operating active streamflow-gaging station on the Smith River, was $224 \mathrm{ft}^{3} / \mathrm{s}$ for the period of record (1997-2010). Annual average streamflow was lower than the overall average annual streamflow in $2007\left(178 \mathrm{ft}^{3} / \mathrm{s}\right)$, was near the average in 2006, 2008, and 2009 (217 to $\left.230 \mathrm{ft}^{3} / \mathrm{s}\right)$, and was the second highest for the period of record in $2010\left(373 \mathrm{ft}^{3} / \mathrm{s}\right)$.
Full-year records (October 1, 2004 through September $30,2010)$ from the uppermost streamflow-gaging station, Smith River below Newlan Creek (station 06076560), and the streamflow-gaging station below Eagle Creek (station 06077200), show a mean annual streamflow increase of $163 \mathrm{ft}^{3} / \mathrm{s}$ along this reach (Nilges and Caldwell, 2012). Therefore, the drainage area between the streamflow gaging stations, Smith River below Newlan Creek (station 06076560) and Smith River below Eagle Creek (station 06077200) contributed about 67 percent of the total streamflow observed at the Smith River below Eagle Creek.

Streamflow data collected seasonally at Smith River near Fort Logan provide a higher spatial resolution of streamflow gains between Smith River below Newlan Creek (station 06076560) and the streamflow-gaging station below Eagle Creek (station 06077200). A median streamflow increase of $36 \mathrm{ft}^{3} / \mathrm{s}$ between the upper two streamflow-gaging stations, Smith River below Newlan Creek $\left(80.9 \mathrm{ft}^{3} / \mathrm{s}\right)$ and Smith River near Fort Logan $\left(117 \mathrm{ft}^{3} / \mathrm{s}\right)$, was observed when comparing data while both streamflow-gaging stations were in operation (intermittent periods between October 1, 2006 through October 31, 2010). Camas Creek is the most significant contributor of tributary inflow along this reach. A median streamflow increase of nearly $76 \mathrm{ft}^{3} / \mathrm{s}$ between the Smith River near Fort Logan $\left(117 \mathrm{ft}^{3} / \mathrm{s}\right)$ and the Smith River below Eagle Creek $\left(193 \mathrm{ft}^{3} / \mathrm{s}\right)$ was observed when both streamflow-gaging stations were in operation (seasonally, 2006 through 2010). Tributary inflow from Sheep Creek was responsible for most of the increase along this reach. 
Data from the two lower streamflow-gaging stations, Smith River below Eagle Creek (station 06077200, continuous operation) and the Smith River near Eden (station 06077500, seasonal operation), indicated a median streamflow increase of $58 \mathrm{ft}^{3} / \mathrm{s}$ (23 percent) by comparing data collected while both streamflow-gaging stations were in operation between March, 2006 and October, 2010. Although there are several tributaries along this 53.8-mi reach of the Smith River, there were periods when streamflow remained nearly identical or even decreased between the two stations. These observations could be affected by travel times, but are also likely affected by gains and losses along this section of the Smith River as it travels through the steep-sided limestone canyon.

\section{Streamflow at Temporary USGS Streamflow- Gaging Stations}

Temporary, study-specific, streamflow-gaging stations on the Smith River and selected tributaries were operated at various times and measurement frequencies (table 1) (fig. 11 and table 1 in Nilges and Caldwell, 2012). The most complete data set was collected during the 2010 water year and allowed for a detailed evaluation of computed daily streamflow of the Smith River and major tributary inflows in the upper Smith River watershed. Although ungaged tributary inflow is likely variable and irrigation diversions during parts of the record were not measured, the net change in Smith River streamflow between the confluence of the North and South Forks of the Smith Rivers and about 10 mi downstream at the Smith River below Newlan Creek streamflow-gaging station (station 06076560) can be generalized for the 2010 record.

\section{Groundwater and Surface-Water Interaction within the Upper Smith River Watershed}

Similar water table and stream stage elevations combined with the significant diversion and application of main stem and tributary waters for irrigation supports a complex set of groundwater and surface-water interactions within the upper Smith River watershed. The interaction between surface water and near-stream groundwater can be qualitatively described as the direction and relative magnitude of flow based on measured groundwater levels, stage, and temperature. Groundwater and surface-water monitoring networks (for example, in- and nearstream monitoring wells and staff gages) provided temporal information to assess seasonal variations at specific locations.

Interactions are quantitatively described as gains and losses during single-day streamflow measurement events along several reaches and as simulated water fluxes between surface water and groundwater based on flow and heat transport modeling. Modeling of the movement of water and heat using temperature and water-level data collected from groundwater and surface-water monitoring networks increased the understanding of the hydraulic properties of the Quaternary alluvium (streambed and underlying aquifer material) and the varying rates of groundwater and surface-water exchange at several locations.

\section{Generalized Groundwater Flow Direction and Streamflow Gains and Losses}

Four large-scale synoptic groundwater-level and streamflow measurements allowed for the evaluation of groundwaterflow directions as well as the location of gaining and losing reaches of measured streams and the magnitude of the fluxes. Potentiometric-surface maps were constructed with water levels measured in approximately 130 wells within 2 weeks of each of the synoptic streamflow measurements. Generalized groundwater-flow directions are perpendicular to the potentiometric-surface contours from areas of recharge to areas of discharge. An understanding of the general direction of groundwater flow in the upper watershed at approximately the same time as the streamflow measurements (seepage runs) was achieved.

Groundwater gains/losses and associated error estimates were calculated along five reaches (fig. 6) for each of the synoptic events. An attempt was made to quantify all major tributary inflows and diversions. However, some small-scale tributaries or drains may have inadvertently been omitted. Therefore, calculated net gains or losses include groundwater inflow and leakage through the streambed, but may also include some small, unmeasured tributaries or diversions. This investigation only addressed gains and losses to the main stem Smith River and the North and South Forks of the Smith River.

\section{Period of Limited Irrigation (October to April)}

Calculated gains and losses from the seepage runs conducted on March 22, 2007; October 16, 2007; and April 10, 2008 , during periods of very limited diversions for irrigation or stock use, differed in magnitude, but the direction (gaining or losing) of flow between the groundwater and the stream a long individual reaches remained the same (table 4). The groundwater levels at individual wells measured during these seepage runs typically varied less than $5 \mathrm{ft}$. Three potentiometric-surface maps constructed for these synoptic events are similar to one another, with only small differences detected at the map scale. A generalized potentiometric-surface map that represents groundwater levels measured during these spring and fall conditions is shown on figure 12. Groundwater generally followed land-surface topography from the uplands to the axis of alluvial valleys of the Smith River and its tributaries. Flow to and from the streams was apparent, especially at the lower ends of the North and South Forks of the Smith River, as well as the upper reach of the main stem Smith River. 
Table 4. Summary of gains and losses calculated from synoptic streamflow measurements during periods of limited diversions, upper Smith River watershed, Montana, 2007-2008.

[Abbreviations: $\mathrm{ft}^{3} / \mathrm{s}$, cubic feet per second.]

\begin{tabular}{|c|c|c|c|c|c|}
\hline Measurement Date & ${ }^{1}$ Reach 1 net gain $\left(\mathrm{ft}^{3} / \mathrm{s}\right)$ & ${ }^{1}$ Reach 2 net loss ( $\mathrm{ft}^{3} / \mathrm{s}$ ) & ${ }^{1}$ Reach 3 net gain $\left(\mathrm{ft}^{3} / \mathrm{s}\right)$ & ${ }^{1}$ Reach 4 net gain $\left(\mathrm{ft}^{3} / \mathrm{s}\right)$ & ${ }^{1}$ Reach 5 net gain $\left(f^{3} / s\right)$ \\
\hline $3 / 22 / 2007$ & $9.33 \pm 0.85$ & $-2.23 \pm 0.92$ & $2.90 \pm 1.98$ & ${ }^{2} 5.69 \pm 7.92$ & $23.2 \pm 19.0$ \\
\hline $10 / 16 / 2007$ & $2.44 \pm 0.43$ & $-8.49 \pm 0.62$ & $4.09 \pm 0.94$ & ${ }^{2} 0.67 \pm 3.55$ & $15.3 \pm 8.56$ \\
\hline
\end{tabular}

${ }^{1}$ River reach shown in figure 6.

${ }^{2}$ Calculated gain is less than associated error.

Groundwater gradients ranged from approximately 10 to $50 \mathrm{ft} /$ mi in the upper Smith River valley.

Summaries of the synoptic streamflow measurements taken on March 22, 2007, October 16, 2007, and April 10, 2008 during periods of limited diversions, and their calculated gains/losses are included in tables 5-7. The South Fork Smith River had net gains ranging from $2.44-9.33 \mathrm{ft}^{3} / \mathrm{s}$ over the lower 14.9-mi reach (reach 1). The lower end of the North Fork Smith River had net losses ranging from $2.23-8.49 \mathrm{ft}^{3} / \mathrm{s}$ over the lower 8.1-mi reach (reach 2). Although tributary inflows accounted for most of the net gains of streamflow over the upper $41.4 \mathrm{mi}$ (reaches 4 and 5) of the main stem Smith River from below the North Fork Smith River to below Eagle Creek, groundwater or undocumented tributaries accounted for 13.0 to $28.9 \mathrm{ft}^{3} / \mathrm{s}$ or 17 to 19 percent of the gains over that section of the stream.

Streamflow profiles constructed for periods of limited irrigation illustrate the spatial distribution of main-stem streamflow due to tributary inflow, inflow from groundwater discharge, and losses due to leakage to groundwater. The streamflow profiles representing synoptic measurements on March 22, 2007, October 16, 2007, and April 10, 2008 were generally similar to one another, although magnitudes of exchanges between groundwater and surface water differed. Instantaneous streamflow measurements on March 22, 2007, along the South Fork Smith River, North Fork Smith River, and the main stem Smith River are illustrated in figure 13. Also shown in figure 13 is the cumulative tributary inflow which includes all visible surficial tributary inflow measured or calculated along these reaches. Cumulative tributary inflow was calculated using the uppermost main-stem streamflow value and adding all tributary inflow in the downstream direction. Theoretically, if no gains or losses to or from the groundwater system occur, the main stem and cumulative tributary inflow would be equal. When the main stem streamflow profile is greater than the cumulative tributary inflow profile, a gain in streamflow from a groundwater source is indicated. When the cumulative tributary inflow is greater than the main-stem streamflow, loss to the groundwater system is indicated.

The streamflow profile of the South Fork Smith River illustrates the initial net loss in streamflow due to leakage to groundwater, followed by downstream increases in streamflow greater than that accounted for by tributary inflow over the next 12 miles with a net gain of nearly $10 \mathrm{ft}^{3} / \mathrm{s}$ (fig. 13A). The profile of the North Fork Smith River illustrates a net loss up to $3.6 \mathrm{ft}^{3} / \mathrm{s}$ from below Spring Creek (river mile 8.4 ) to river mile 2.6 as main-stem streamflow falls below the cumulative tributary inflow (fig. 13B). The North Fork Smith River gained $1.4 \mathrm{ft}^{3} / \mathrm{s}$ as it traveled downstream between river miles 2.6 and 0.3 . The streamflow profile of the Smith River starting at the confluence of the North Fork and South Fork Smith Rivers and continuing downstream to the streamflow gaging station below Eagle Creek showed the most dramatic increases in streamflow from tributary inflow, namely Sheep Creek. Only a gradual increase in streamflow attributed to groundwater inflow is apparent along this reach on March 22, 2007 (fig. 13C).

\section{Irrigation Season (May through September)}

The August 1, 2007 synoptic measurements represent an example of streamflow conditions during the irrigation season when snowmelt conditions have long passed and evapotranspiration (Bureau of Reclamation, 2007) is near its peak (table 8 , and fig. 14). Changes in streamflow represent not only tributary inflow and gains and losses to and from the groundwater system, but also the effects of reservoir operations and numerous irrigation diversions that were not measured. Inflows from several tributaries were estimated using upstream and downstream main-stem measurements during this exercise. Because of these data limitations, discussions in this section are in terms of net increase or decrease of streamflow rather than gains or losses through the streambed. Fewer sites were measured during this synoptic event in comparison to the three measurements during periods of limited diversion. Therefore, the stream reaches varied slightly (note: lower extents of North and South Forks of the Smith River reaches were adjusted slightly upstream).

The August 1, 2007 synoptic measurements generally resulted in larger net decreases and smaller net increases in streamflow in comparison to the similar reaches measured before and after the irrigation season. The South Fork Smith River had a net increase in streamflow that was less than the estimated errors over the 11.9-mi reach (reach 1). The South Fork Smith River was almost dry in the upper section (between river miles 15.0 and 11.8) and then transitioned to a gaining stream along the lower section. Losses in the upper 


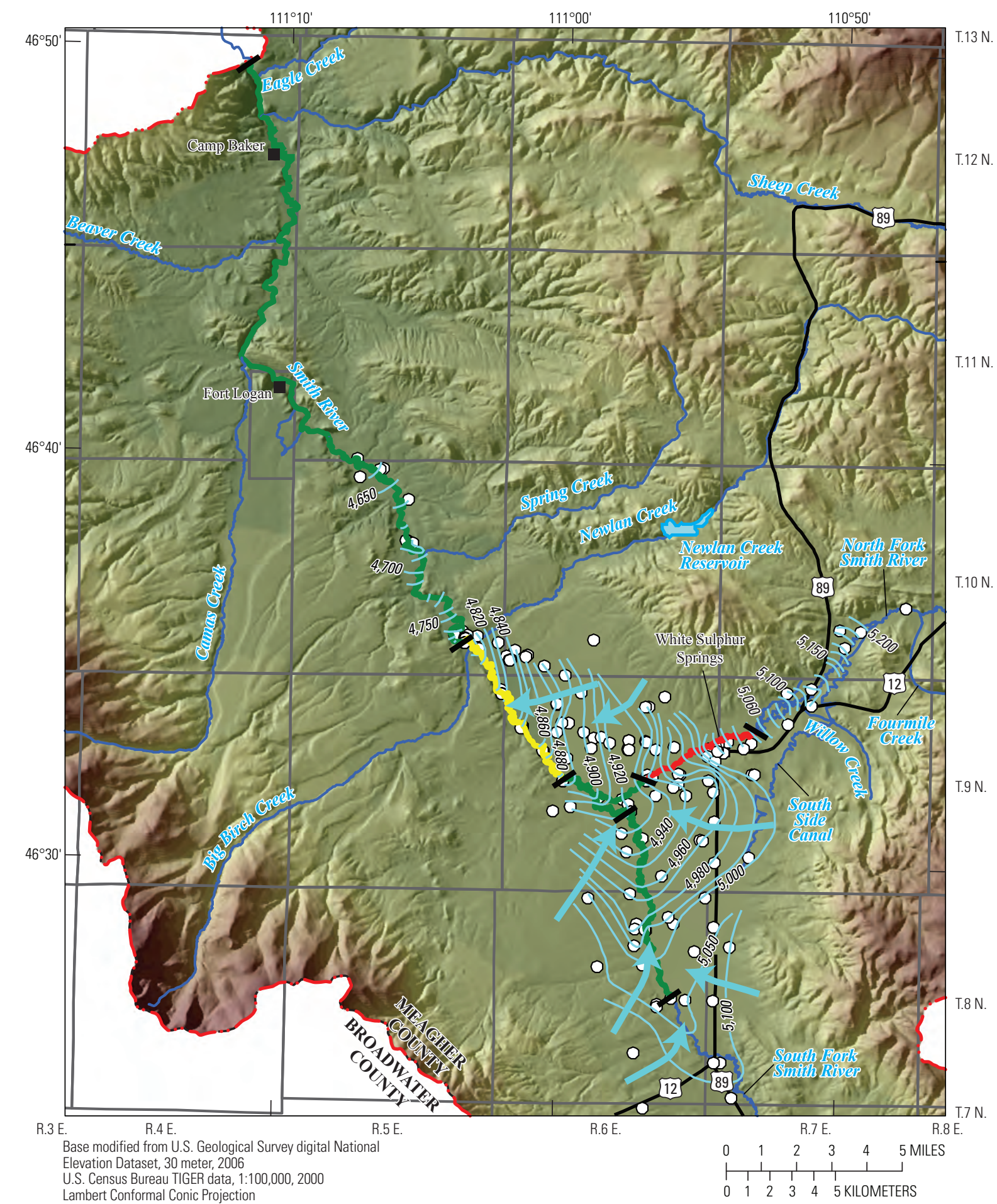

ambert Conforma Conic Projection

Standard parallels $45^{\circ}$ and $49^{\circ}$, central meridian $-109^{\circ} 30^{\prime \prime}$ North American Datum of 1983 (NAD83).

\section{EXPLANATION}

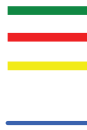

Gaining Reach

Losing Reach

Neutral Reach-Errors large than calculated gain or loss

Unmeasured Reach

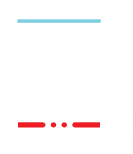

Potentiometric contour-Shows altitude at which water would have stood in tightly cased wells generalized from March 2007, October 2007, and April 2008 measurements. Contour intervals 10 and 50 feet. Datum is North American Vertical Datum of 1988 Upper Smith River Watershed boundary
General groundwater-flow direction

\section{Study well}

Extent of stream reach

Figure 12. Generalized potentiometric surface, groundwater-flow direction, and delineation of gaining and losing stream reaches during periods of limited diversions, upper Smith River watershed, Montana, 2007-2008. (Based on synoptic measurements during March 2007, October 2007, and April 2008). 
Table 5. Estimated streamflow gains and losses, upper Smith River Watershed, Montana, March 22, 2007.

[Station identification number, see "Site-Identification Systems" section for explanation; River mile, distance above mouth; Temperature, water temperature in degrees Celsius; Streamflow measurement rating: (G) good (less than 5 percent measurement error), (F) fair ( 5 to 8 percent measurement error), (P) poor (greater than 8 percent measurement error). Abbreviations: ${ }^{\circ} \mathrm{C}$, degrees Celsius; $\mu \mathrm{S} / \mathrm{cm}$, microsiemens per centimeter at 25 degrees Celsius; $\mathrm{ft}^{3} / \mathrm{s}$, cubic feet per second. Symbols: --, not applicable or not measured. Note: main-stem values in bold type

\begin{tabular}{|c|c|c|c|c|c|c|c|c|c|c|}
\hline Location description & $\begin{array}{c}\text { Station } \\
\text { identification } \\
\text { number }\end{array}$ & Time & $\begin{array}{c}\text { River } \\
\text { mile }\end{array}$ & $\begin{array}{l}\text { Temp- } \\
\text { era- } \\
\text { ture } \\
\left({ }^{\circ} \mathrm{C}\right)\end{array}$ & $\begin{array}{c}\text { Specific } \\
\text { conduc- } \\
\text { tance } \\
(\mu \mathrm{S} / \mathrm{cm})\end{array}$ & $\begin{array}{c}\text { Main- } \\
\text { stem } \\
\text { stream- } \\
\text { flow } \\
\left(\mathrm{ft}^{3} / \mathrm{s}\right)\end{array}$ & $\begin{array}{l}\text { Tributary } \\
\text { stream- } \\
\text { flow } \\
\left(\mathrm{ft}^{3} / \mathrm{s}\right)\end{array}$ & $\begin{array}{c}\text { Streamflow } \\
\text { measure- } \\
\text { ment rating }\end{array}$ & $\begin{array}{c}\text { Estimated } \\
\text { measurement } \\
\text { error }\left(\mathrm{ft}^{3} / \mathrm{s}\right)\end{array}$ & $\begin{array}{l}\text { Estimated streamflow gain } \\
(+) \text { or loss }(-) \text { and associated } \\
\text { measurement error }\left(\mathrm{ft}^{3} / \mathrm{s}\right)\end{array}$ \\
\hline \multicolumn{11}{|c|}{ Reach 1 (fig. 6) - South Fork Smith River } \\
\hline $\begin{array}{l}\text { South Fork Smith River at Birky Road } 1.6 \text { miles } \\
\text { below Cottonwood Creek }\end{array}$ & 06075775 & 9:00 & 15.0 & 2.5 & 860 & 5.28 & -- & G & 0.26 & - \\
\hline $\begin{array}{l}\text { South Fork Smith River } 4.8 \text { miles below Cotton- } \\
\text { wood Creek }\end{array}$ & 06075780 & $8: 42$ & 11.8 & 1.7 & 814 & 4.94 & -- & G & 0.25 & $-0.34 \pm 0.36$ \\
\hline Hot Springs Creek at mouth & 463057110570301 & $9: 55$ & 4.3 & 3.0 & 954 & -- & 0.88 & $\mathrm{~F}$ & 0.07 & -- \\
\hline $\begin{array}{l}\text { Unnamed tributary to South Fork Smith River } \\
\text { (number 1) }\end{array}$ & 463107110571401 & 10:15 & 3.8 & 4.2 & 611 & -- & 0.43 & $\mathrm{P}$ & 0.04 & -- \\
\hline $\begin{array}{l}\text { Unnamed tributary to South Fork Smith River } \\
\text { (number 2) }\end{array}$ & 463120110571701 & 10:50 & 3.2 & 3.8 & 801 & -- & 0.18 & $\mathrm{P}$ & 0.02 & -- \\
\hline South Fork Smith River near mouth & 06075785 & 11:05 & 3.1 & 3.4 & 747 & 11.6 & -- & G & 0.58 & $5.17 \pm 0.64$ \\
\hline South Fork Smith River at mouth & 463141110583701 & $13: 30$ & 0.1 & 6.3 & 701 & 16.1 & -- & G & 0.81 & $4.50 \pm 0.99$ \\
\hline Total (14.9 river miles) & & & & & & & & & Net gain & $9.33 \pm 0.85$ \\
\hline \multicolumn{11}{|c|}{ Reach 2 (fig. 6) - North Fork Smith River } \\
\hline North Fork Smith River above Spring Creek & 463327110523701 & 9:17 & 8.4 & 1.3 & 337 & 7.06 & -- & G & 0.35 & -- \\
\hline Spring Creek near mouth & 463333110525501 & $9: 50$ & 8.4 & 4.8 & 290 & -- & 9.37 & G & 0.47 & -- \\
\hline North Fork Smith River at Highway 360 bridge & 463256110545201 & 11:00 & 5.3 & 3.3 & 330 & 15.2 & -- & G & 0.76 & $-1.23 \pm 0.96$ \\
\hline North Fork Smith River near mouth & 06075700 & 12:00 & 2.6 & 4.3 & 341 & 12.8 & -- & $\mathbf{F}$ & 1.02 & $-2.40 \pm 1.28$ \\
\hline North Fork Smith River at mouth & 463148110583001 & $12: 55$ & 0.3 & 5.5 & 337 & 14.2 & -- & G & 0.71 & $1.40 \pm 1.25$ \\
\hline Total (8.1 river miles) & & & & & & & & & Net Loss & $-2.23 \pm 0.92$ \\
\hline \multicolumn{11}{|c|}{ Reach 3 (fig. 6) - Upper Smith River below confluence of North and South Forks of Smith River } \\
\hline South Fork Smith River at mouth & 463141110583701 & $13: 30$ & 124.8 & 6.3 & 701 & 16.1 & -- & $\mathbf{G}$ & 0.81 & -- \\
\hline North Fork Smith River at mouth & 463148110583001 & $12: 55$ & 124.7 & 5.5 & 337 & 14.2 & -- & $\mathbf{G}$ & 0.71 & -- \\
\hline Smith River below North Fork Smith River & 06075810 & $14: 40$ & 122.2 & 6.4 & 549 & 33.2 & -- & G & 1.66 & -- \\
\hline Total (2.6 river miles) & & & & & & & & & Net gain & $2.90 \pm 1.98$ \\
\hline
\end{tabular}


Table 5. Estimated streamflow gains and losses, upper Smith River Watershed, Montana, March 22, 2007.—Continued

[Station identification number, see "Site-Identification Systems" section for explanation; River mile, distance above mouth; Temperature, water temperature in degrees Celsius; Streamflow measurement rating: (G) good (less than 5 percent measurement error), (F) fair $\left(5\right.$ to 8 percent measurement error), (P) poor (greater than 8 percent measurement error). Abbreviations: ${ }^{\circ} \mathrm{C}$, degrees Celsius; $\mu \mathrm{S} / \mathrm{cm}$, microsiemens per centimeter at 25 degrees Celsius; $\mathrm{ft}^{3} / \mathrm{s}$, cubic feet per second. Symbols: --, not applicable or not measured. Note: main-stem values in bold type]

\begin{tabular}{|c|c|c|c|c|c|c|c|c|c|c|}
\hline Location description & $\begin{array}{c}\text { Station } \\
\text { identification } \\
\text { number }\end{array}$ & Time & $\begin{array}{c}\text { River } \\
\text { mile }\end{array}$ & $\begin{array}{l}\text { Temp- } \\
\text { erature } \\
\left({ }^{\circ} \mathrm{C}\right)\end{array}$ & $\begin{array}{c}\text { Specific } \\
\text { conduc- } \\
\text { tance } \\
(\mu \mathrm{S} / \mathrm{cm})\end{array}$ & $\begin{array}{c}\text { Main- } \\
\text { stem } \\
\text { stream- } \\
\text { flow } \\
\left(\mathrm{ft}^{3} / \mathbf{s}\right)\end{array}$ & $\begin{array}{l}\text { Tributary } \\
\text { stream- } \\
\text { flow } \\
\left(\mathrm{ft}^{3} / \mathrm{s}\right)\end{array}$ & $\begin{array}{l}\text { Streamflow } \\
\text { measure- } \\
\text { ment rating }\end{array}$ & $\begin{array}{c}\text { Estimated } \\
\text { measurement } \\
\text { error }\left(\mathrm{ft}^{3} / \mathrm{s}\right)\end{array}$ & $\begin{array}{l}\text { Estimated streamflow gain } \\
(+) \text { or loss }(-) \text { and associated } \\
\text { measurement error }\left(\mathrm{ft}^{3} / \mathrm{s}\right)\end{array}$ \\
\hline \multicolumn{11}{|c|}{ Reach 4 (fig. 6) - Smith River between below North Fork Smith River and the USGS Gage 06076560 below Newlan Creek } \\
\hline Smith River below North Fork Smith River & 06075810 & $14: 40$ & 122.2 & 6.4 & 549 & 33.2 & -- & G & 1.66 & -- \\
\hline Smith River above unnammed tributary & 463241111001801 & 9:40 & 120.8 & 2.6 & 559 & 35.2 & -- & $\mathbf{F}$ & 2.82 & $2.00 \pm 3.27$ \\
\hline $\begin{array}{l}\text { Unnamed tributary at mouth } 0.5 \text { miles above Birch } \\
\text { Creek Road }\end{array}$ & 463240111001501 & $9: 45$ & 120.7 & 4.2 & 471 & -- & 1.25 & $\mathrm{~F}$ & 0.10 & -- \\
\hline Ditch at mouth on south side of Birch Creek Road & 463253111002901 & $9: 45$ & 120.3 & 1.3 & 470 & -- & 0.75 & $\mathrm{~F}$ & 0.06 & -- \\
\hline Ditch at mouth on north side of Birch Creek Road & 463255111002801 & $9: 58$ & 120.2 & 2.8 & 439 & -- & .68 & $\mathrm{~F}$ & 0.05 & -- \\
\hline Woods Gulch at mouth & 463313111010501 & $11: 15$ & 119.1 & 4.2 & 503 & -- & 1.61 & $\mathrm{~F}$ & 0.13 & -- \\
\hline Ditch at mouth below Woods Gulch & 463330111011201 & $12: 50$ & 118.4 & 6.1 & 480 & -- & 3.33 & $\mathrm{~F}$ & 0.27 & -- \\
\hline Ditch at mouth above Mud Springs Creek (number 1) & 463413111014701 & $14: 20$ & 117.1 & 6.3 & 515 & -- & 1.91 & $\mathrm{~F}$ & 0.15 & -- \\
\hline Ditch at mouth above Mud Springs Creek (number 2) & 463355111013901 & $14: 55$ & 116.3 & 7.2 & 495 & -- & 1.25 & $\mathrm{~F}$ & 0.10 & -- \\
\hline Smith River above Mud Springs Creek & 06075850 & $14: 00$ & 116.0 & 5.2 & 541 & 46.7 & -- & $\mathbf{F}$ & 3.74 & $0.72 \pm 4.69$ \\
\hline${ }^{1}$ Mud Springs Creek (calculated) & -- & -- & 115.3 & -- & -- & -- & 2.10 & -- & 5.40 & -- \\
\hline Smith River below Mud Springs Creek & 463437111021701 & $15: 50$ & 115.2 & 6.6 & 536 & 48.8 & -- & $\mathbf{F}$ & 3.90 & -- \\
\hline Smith River above Big Birch Creek & 463518111030101 & $9: 20$ & 112.7 & 2.9 & 542 & 51.6 & -- & $\mathbf{F}$ & 4.13 & $2.80 \pm 5.68$ \\
\hline Big Birch Creek at mouth & 06075900 & $10: 20$ & 112.6 & 1.9 & 238 & -- & 11.1 & G & 0.56 & -- \\
\hline Newlan Creek at mouth & 06076550 & $11: 15$ & 112.4 & 2.5 & 481 & -- & 5.93 & G & 0.30 & -- \\
\hline Smith River below Newlan Creek & 06076560 & $13: 40$ & 112.1 & 4.1 & 490 & 68.8 & -- & $\mathbf{F}$ & 5.50 & $0.17 \pm 6.91$ \\
\hline Total (10.1 river miles) & & & & & & & & & ${ }^{2}$ Net gain & $5.69 \pm 7.92$ \\
\hline \multicolumn{11}{|c|}{ Reach 5 (fig. 6) - Smith River below Newlan Creek to Smith River below Eagle Creek } \\
\hline Smith River below Newlan Creek & 06076560 & $13: 40$ & 112.1 & 4.1 & 490 & 68.8 & -- & $\mathbf{F}$ & 5.50 & -- \\
\hline Smith River above Thompson Gulch & 463636111050701 & $15: 35$ & 108.2 & 6.1 & 487 & 68.0 & -- & G & 3.40 & $-0.80 \pm 6.47$ \\
\hline Thompson Gulch near mouth & 463638111051801 & $11: 05$ & 108.1 & 5.5 & 345 & -- & 1.35 & $\mathrm{~F}$ & 0.11 & -- \\
\hline Spring Creek at Highway 360 bridge & 463743111042701 & $12: 10$ & 106.5 & 5.1 & 476 & -- & 0.65 & $\mathrm{~F}$ & 0.05 & -- \\
\hline Smith River above Rock Springs Creek & 06076580 & $12: 35$ & 105.1 & 4.7 & 473 & 71.3 & -- & G & 3.57 & $1.30 \pm 4.93$ \\
\hline Smith River below Rock Springs Creek & 463911111055501 & $13: 36$ & 103.1 & 4.8 & 473 & 73.8 & -- & G & 3.69 & $2.50 \pm 5.13$ \\
\hline Smith River at Highway 360 bridge & 464033111083501 & $11: 00$ & 98.4 & 3.3 & 461 & 76.9 & -- & $\mathbf{F}$ & 6.15 & $3.10 \pm 7.17$ \\
\hline
\end{tabular}




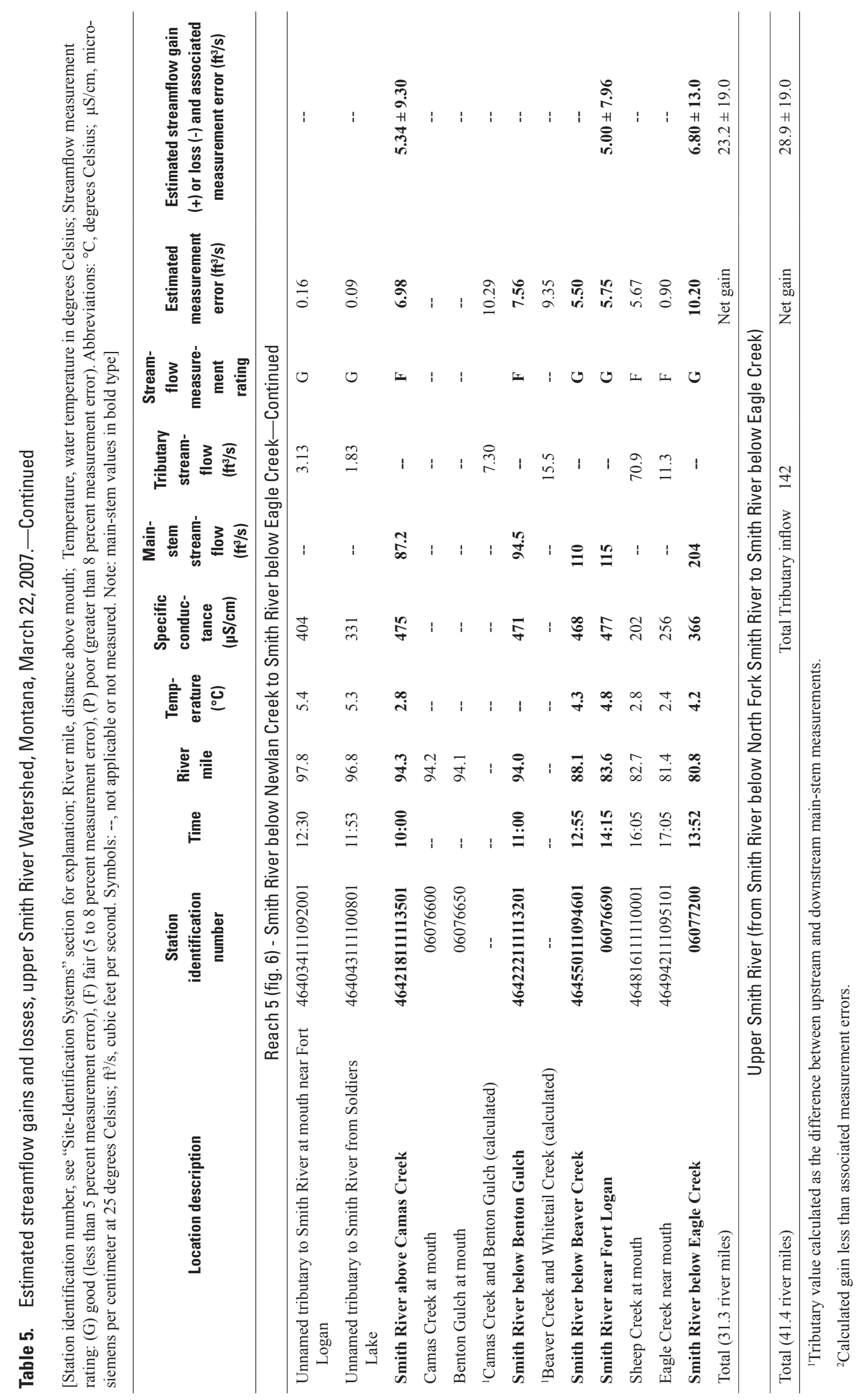




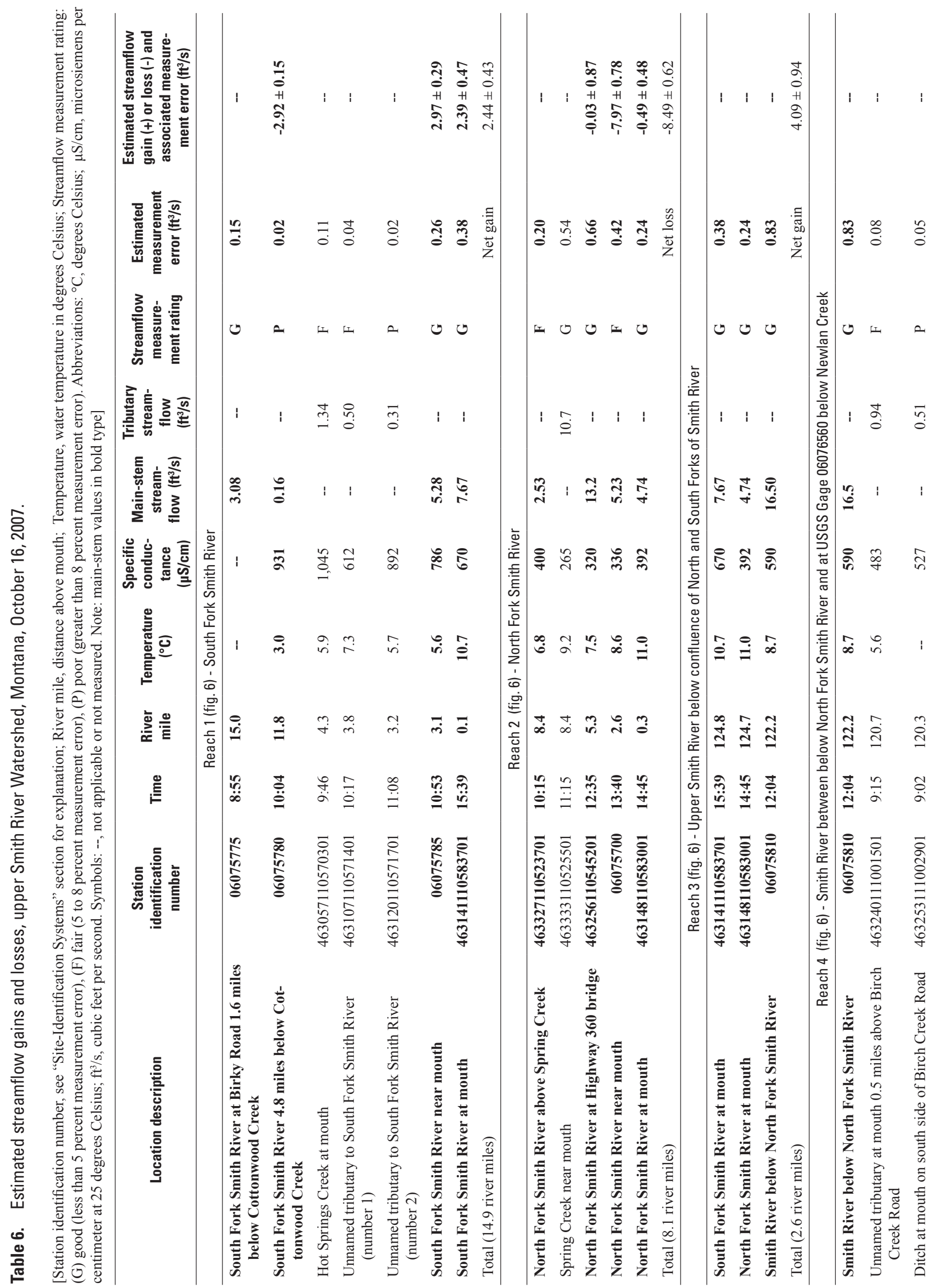




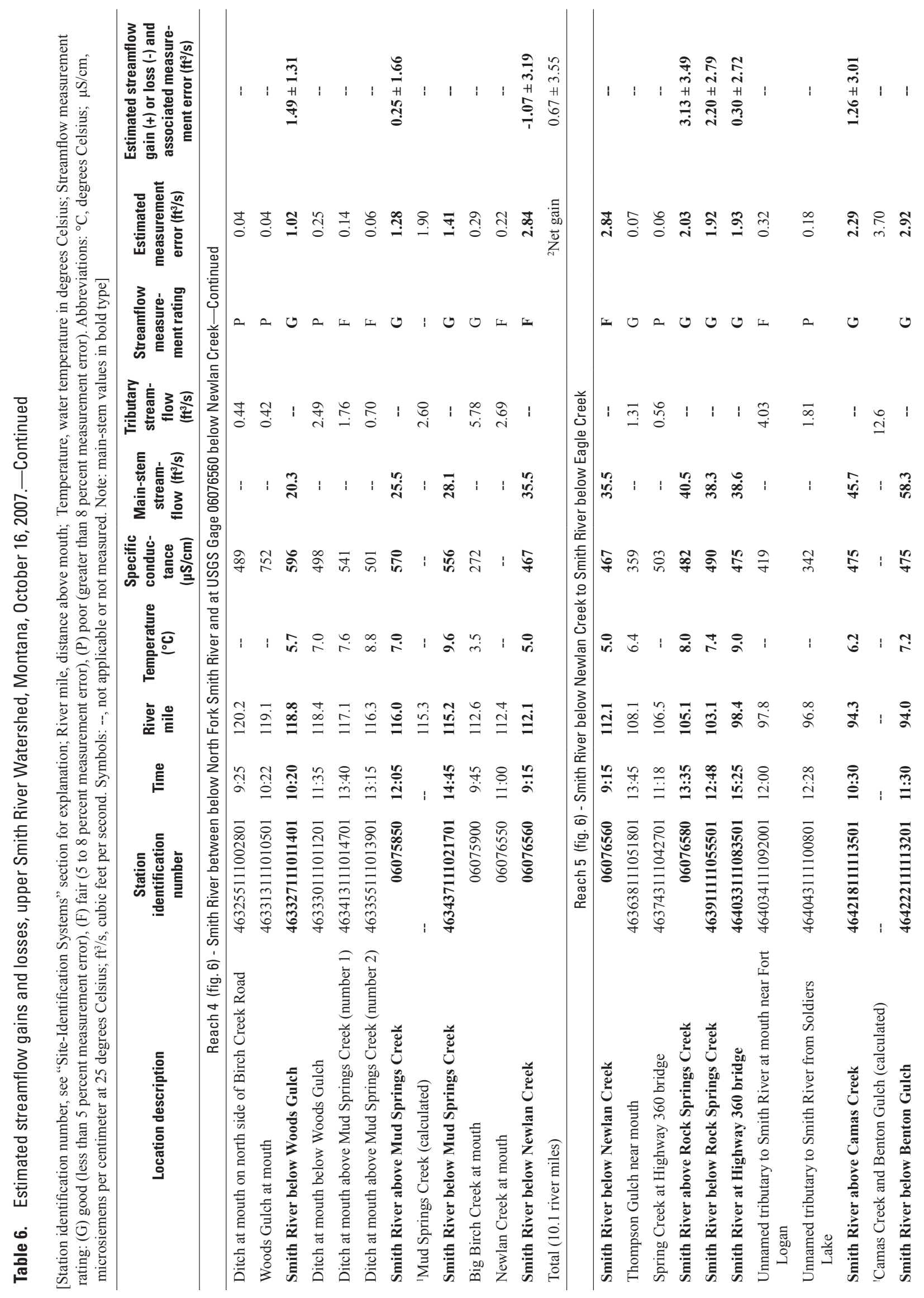




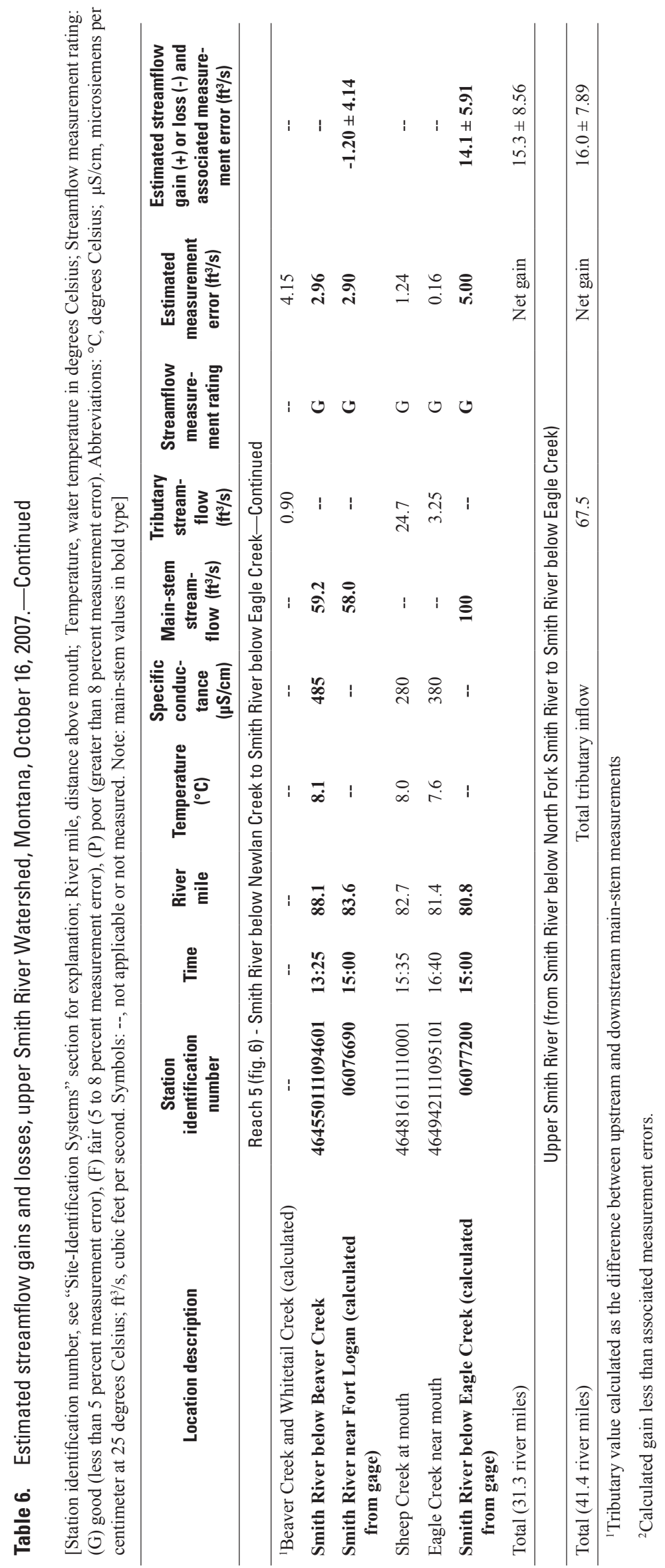




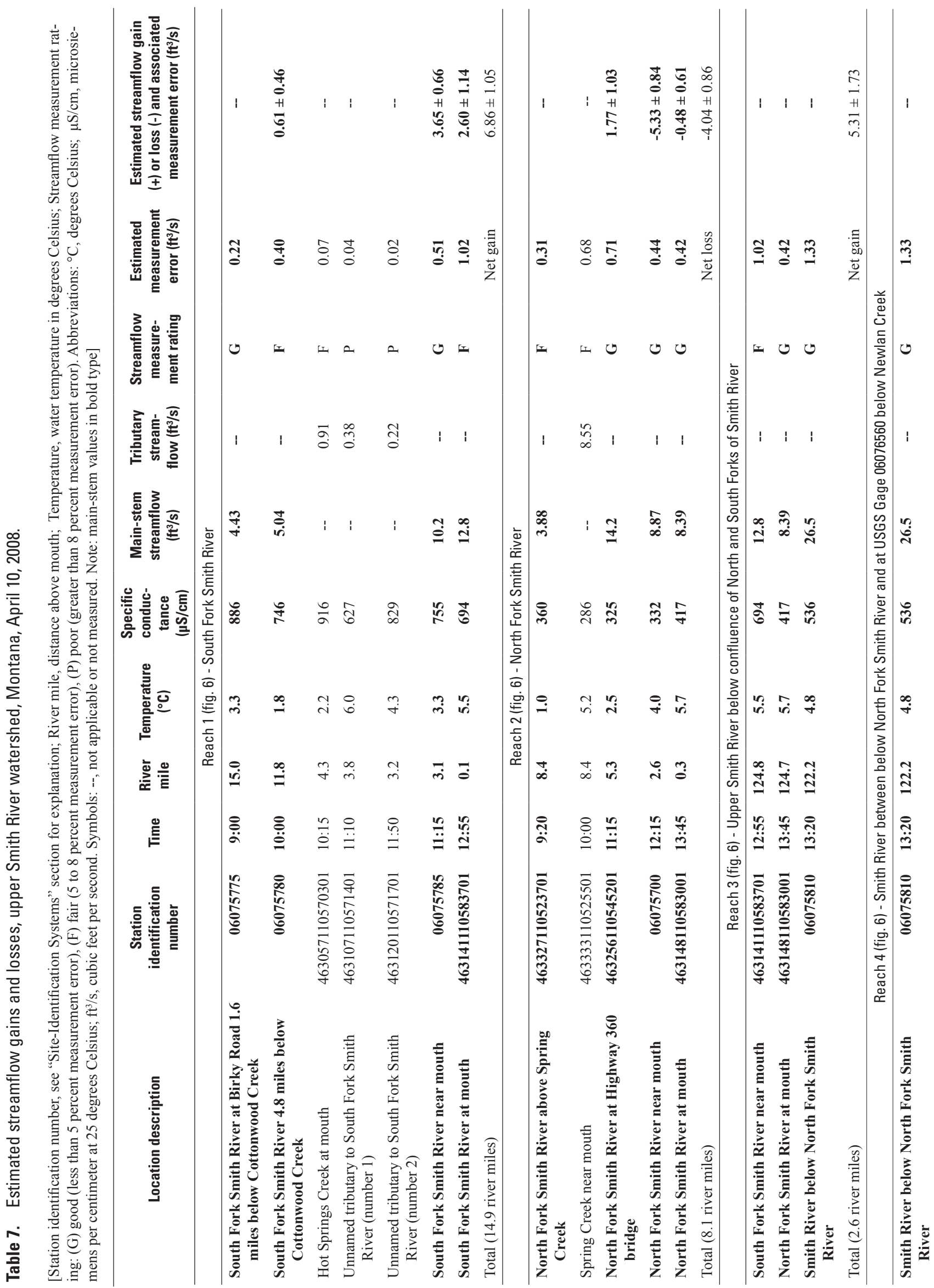




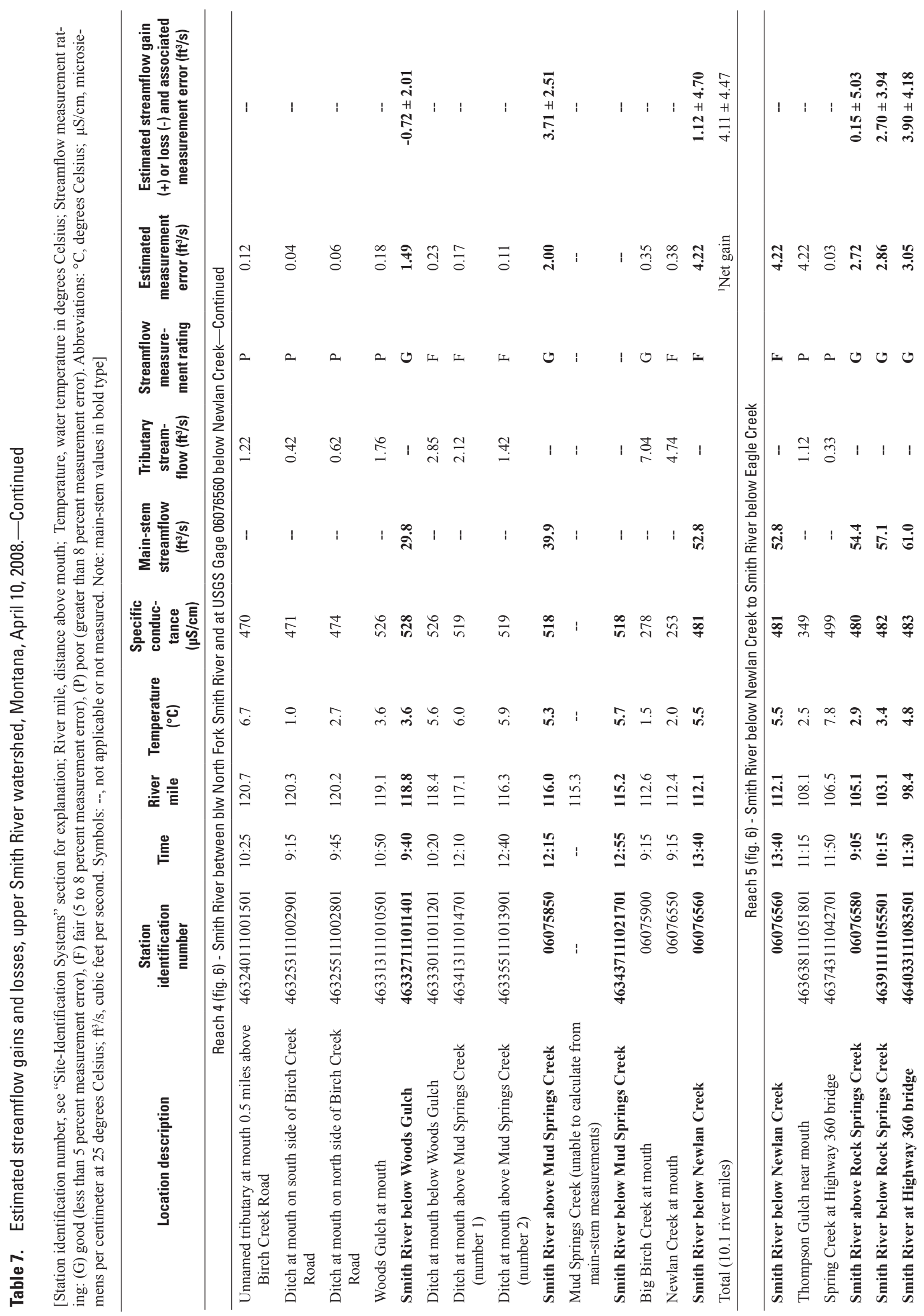




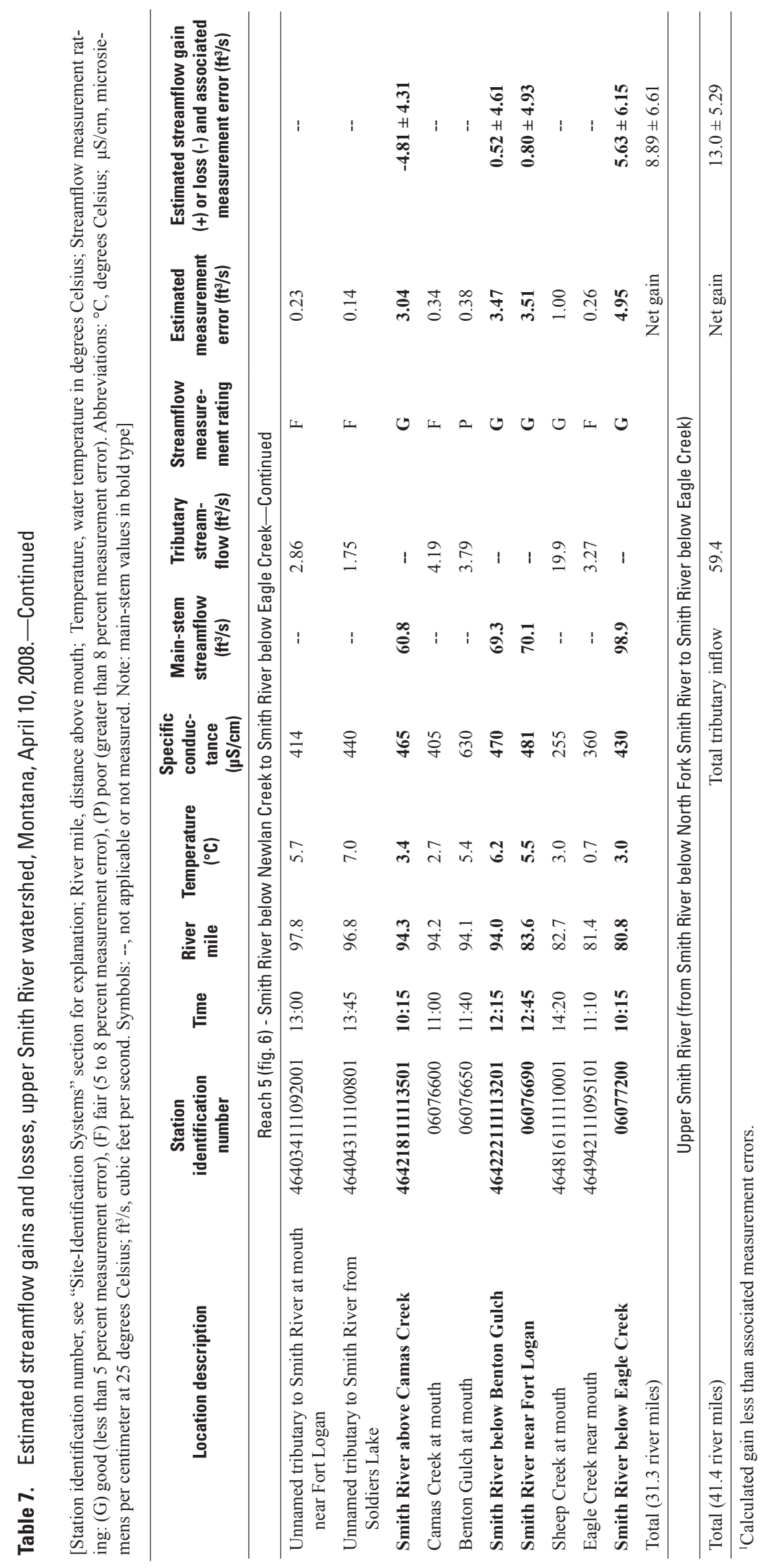



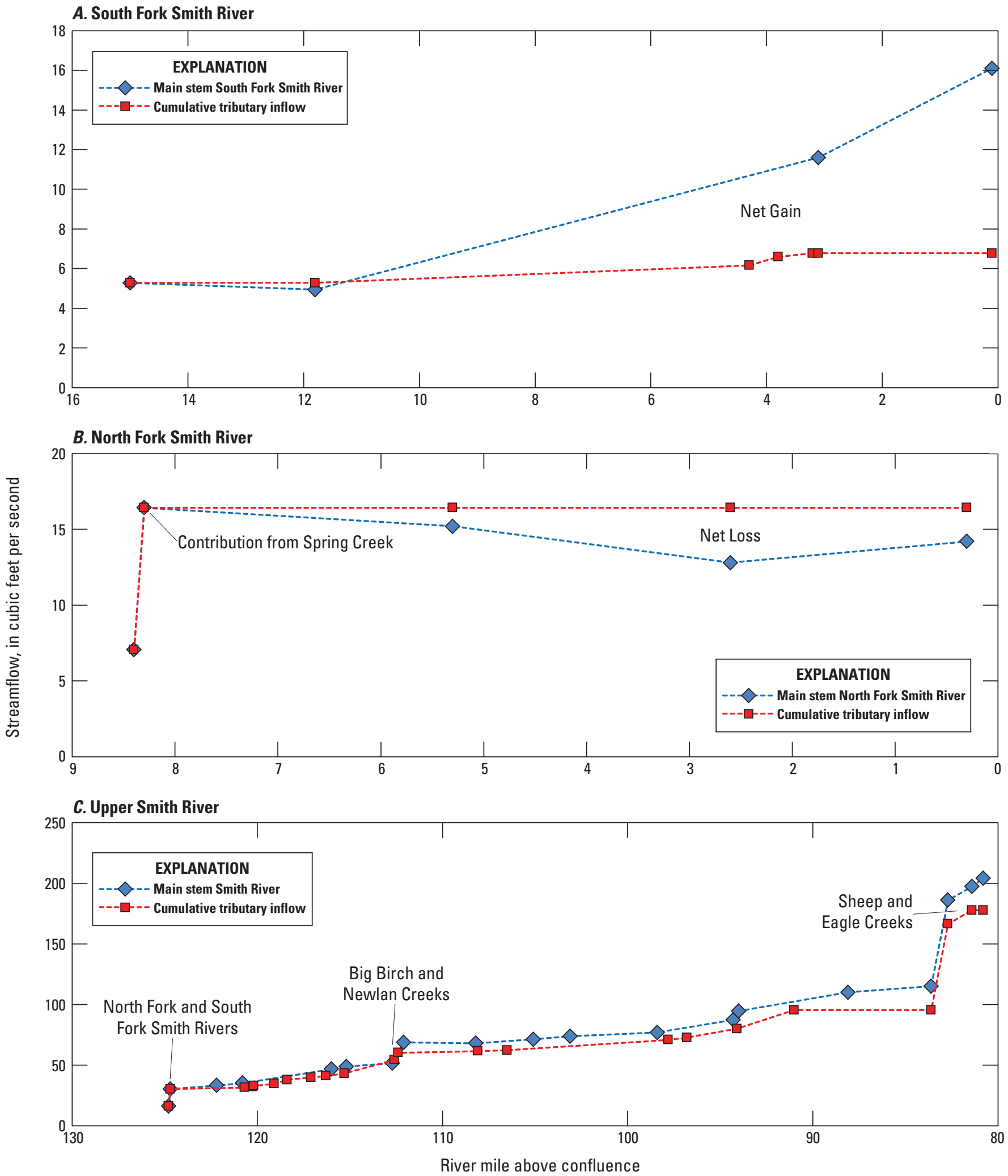

Figure 13. Instantaneous streamflow and cumulative tributary inflow of the $A$, South Fork Smith River; $B$, North Fork Smith River; and C, upper Smith River, Montana, March 22, 2007. 


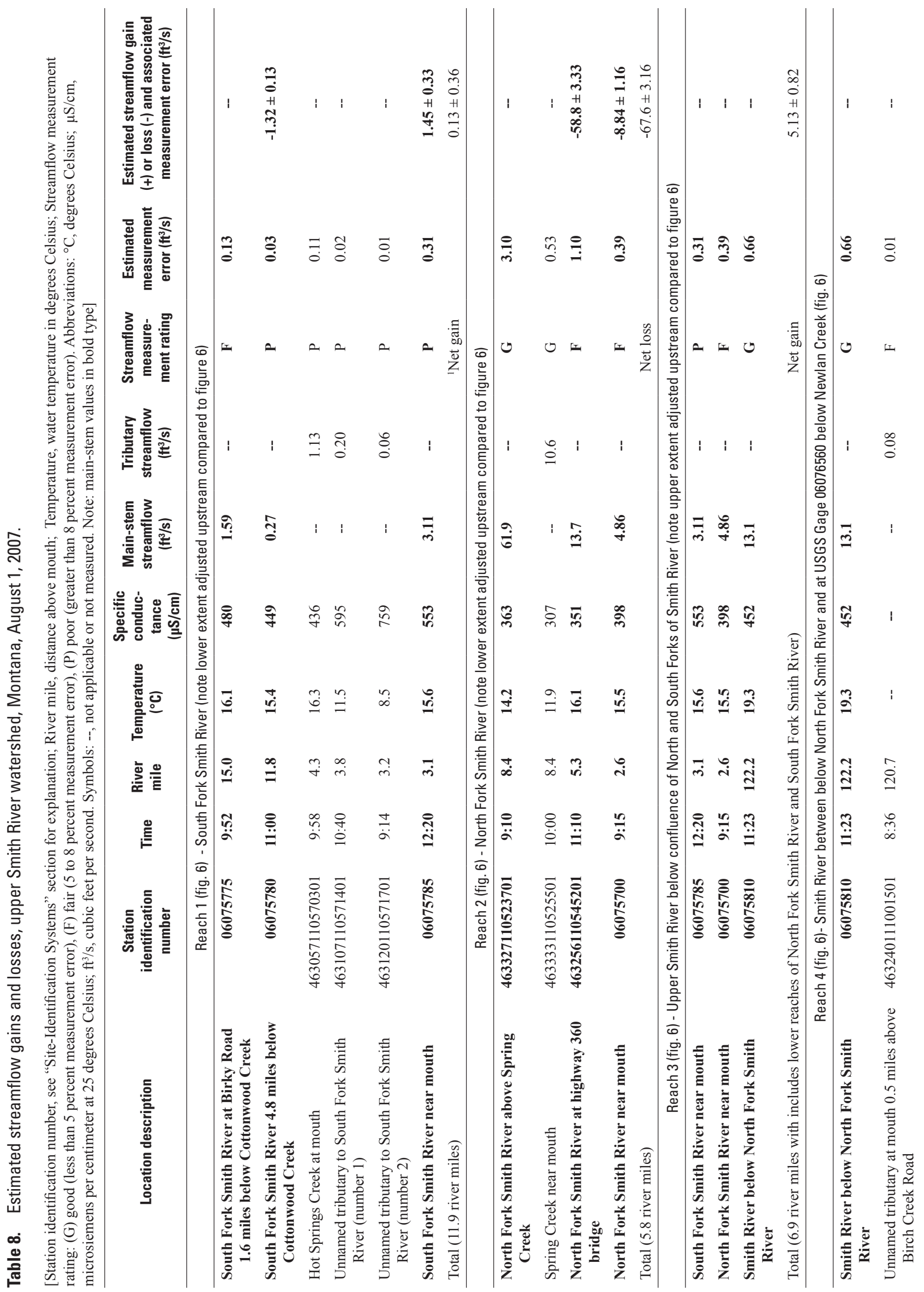




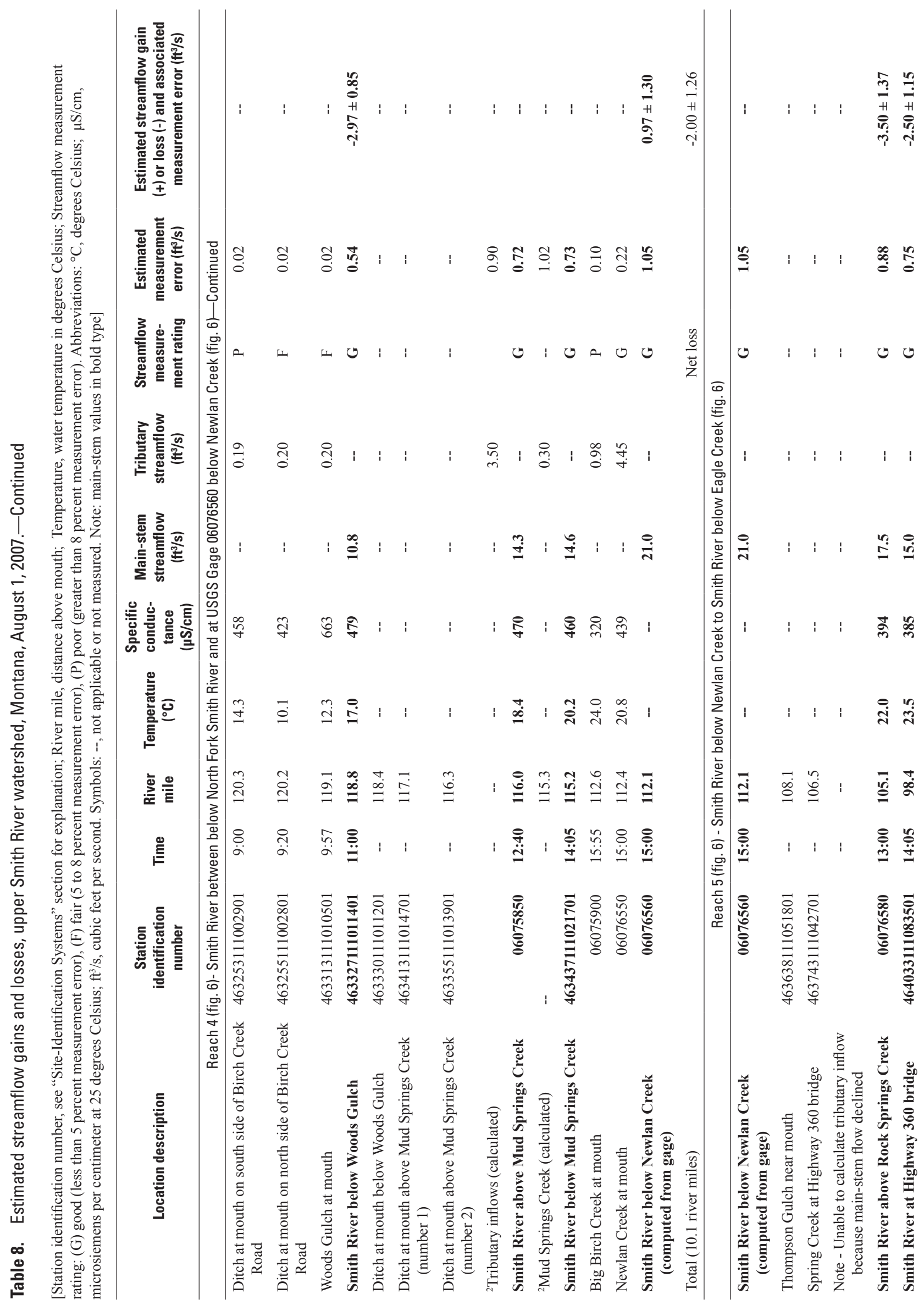




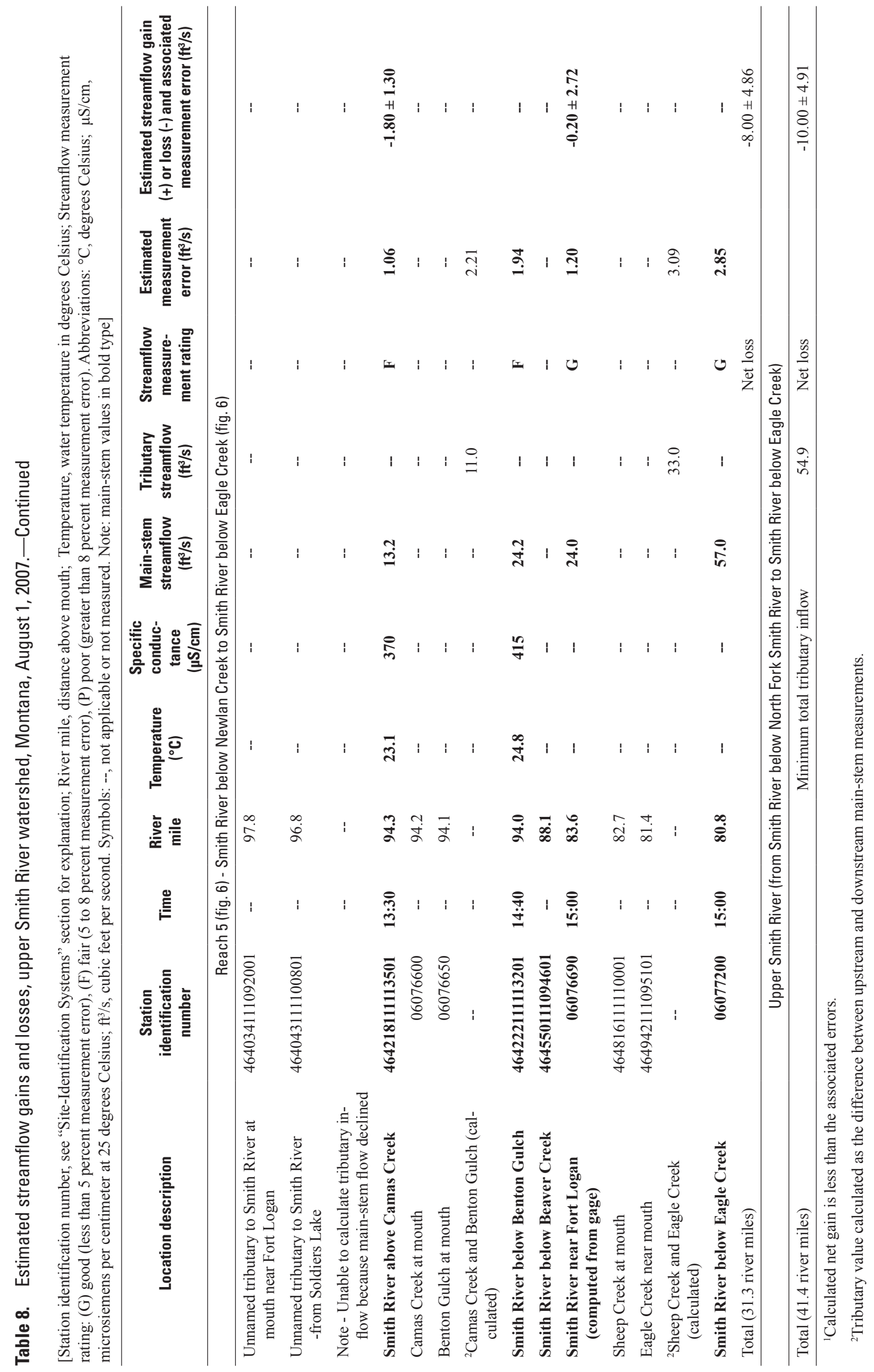




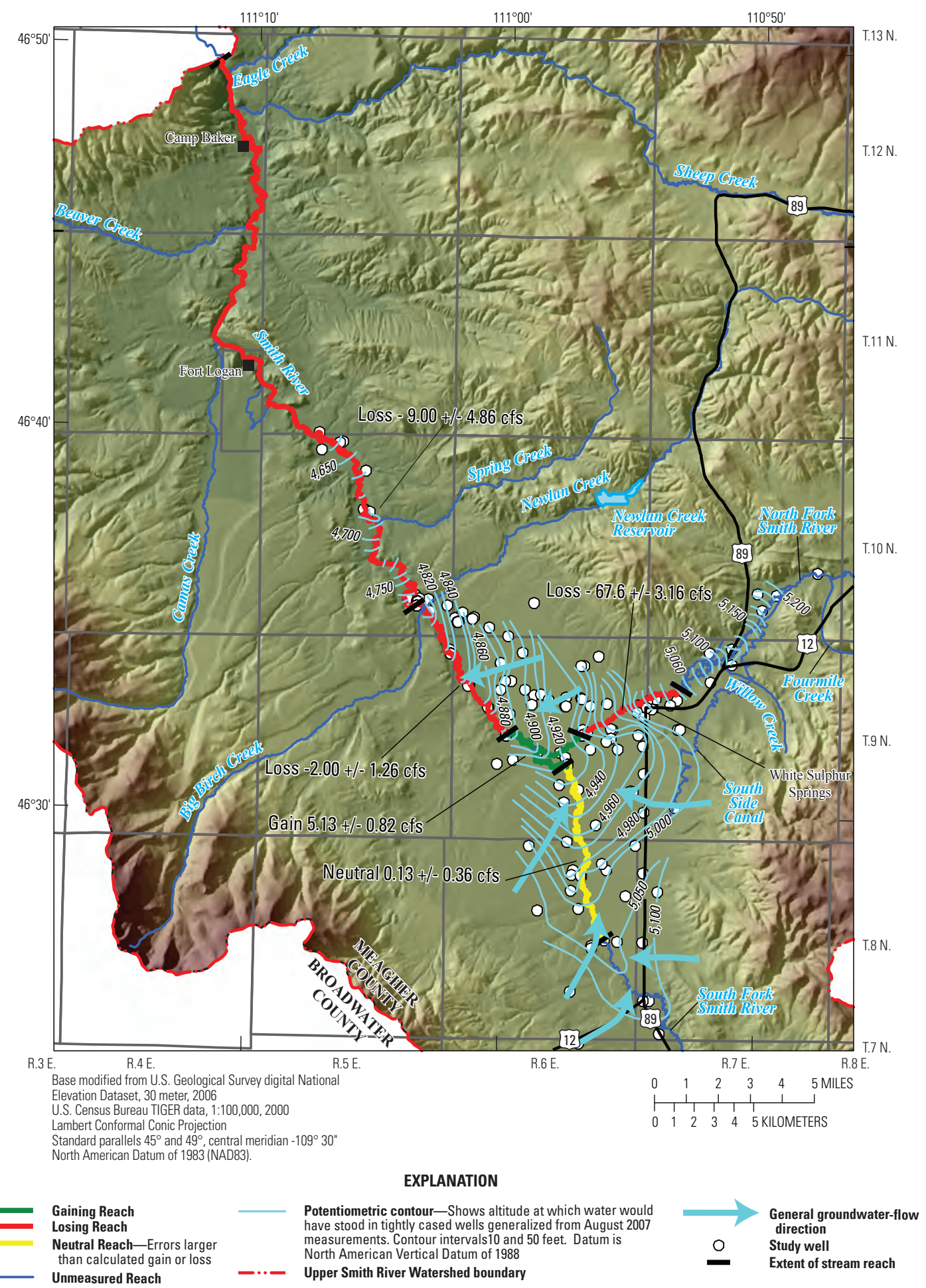

Figure 14. Generalized potentiometric surface, groundwater-flow direction, and delineation of gaining and losing stream reaches during irrigation season conditions, upper Smith River watershed, Montana, August 2007. 
sections are due to a combination of diversions and groundwater levels that are lower than the stream stage supporting losing conditions. As you travel downstream near the mouth, groundwater levels are higher than the stream stage supporting streamflow gains. The North Fork Smith River had a net streamflow decrease of $67.6 \mathrm{ft}^{3} / \mathrm{s}$ over the lower 5.8-mi reach (reach 2) which is likely due to the effects of several irrigation diversions active during that measurement. A net 5.13 $\mathrm{ft}^{3} / \mathrm{s}$ gain was calculated for the area including the confluence of the North and South Forks of the Smith River. There were no observed diversions occurring within this area and the calculated net gain is similar to gains calculated from the non-irrigation season synoptic measurements. Available data from the upper $41.4 \mathrm{mi}$ (reaches 4 and 5) of the main stem Smith River indicated a net streamflow decrease (either from loss to groundwater or diversions) of $11.0 \mathrm{ft}^{3} / \mathrm{s}$, which likely underestimates the actual decrease since tributary inflow was underrepresented.

Streamflow profiles constructed from data collected August 1, 2007 illustrates conditions during a period of irrigation with large-scale diversions in combination with effects due to tributary inflow, inflow from groundwater discharge, and losses due to leakage to groundwater (fig. 15). In several cases, main-stem streamflow declined downstream even with the addition of tributary inflow. The streamflow profile of the upper section of the South Fork Smith River illustrates the overall net loss in streamflow to a point where the stream nearly went dry due to leakage to groundwater and diversions (fig. 15A). At some point downstream from river mile 11 , groundwater discharge caused streamflow to increase. An overall net gain in streamflow was measured by the end of the reach (fig. 15A). The profile of the North Fork Smith River illustrates a $67.6 \mathrm{ft}^{3} / \mathrm{s}$ net loss from below Spring Creek (river mile 8.4) to river mile 2.6 as main-stem streamflow was less than the cumulative tributary inflow (fig. 15B). These net losses were primarily due to irrigation diversions and to a smaller extent, losses to groundwater. In several cases, net losses occurred along reaches even though tributary inflow was occurring. The streamflow profile of the Smith River representing the 44-mi reach starting above the confluence of the North Fork and South Fork Smith Rivers and continuing downstream to the streamflow gaging station below Eagle Creek shows only slight net gains or losses followed by the most dramatic changes in streamflow due to tributary inflow from Sheep Creek (fig. 15C).

\section{Estimated Groundwater Discharge and the Effects of Irrigation Practices on Streamflow}

Streamflow data from several streamflow-gaging stations operated continuously from April 1 through September 30, 2010 were used to estimate the amount of groundwater that discharged to the Smith River and the effects of irrigation practices on streamflow in the upper watershed. The computed daily streamflow of the Smith River below Newlan
Creek streamflow-gaging station (station 06076560) and the combined (summed) daily streamflow of the major tributaries above this gage including the North and South Forks of the Smith River, Big Birch Creek, and Newlan Creek are shown in figure 16. The several small-scale tributaries, drains, and springs within this area that were ungaged in 2010 were measured during the synoptic events in March and October 2007, and April 2008, and accounted for an average inflow of $11.0 \mathrm{ft}^{3} / \mathrm{s}$ (see Generalized Groundwater Flow Direction and Streamflow Gains and Losses section). The average daily streamflow at the Smith River below Newlan Creek streamflow-gaging station was $27.5 \mathrm{ft}^{3} / \mathrm{s}$ greater than the sum of the upstream gaged tributaries in 2010. Assuming an average of $11 \mathrm{ft}^{3} / \mathrm{s}$ of inflow from ungaged tributaries, groundwater inflow to the Smith River along this reach may account for an average of about $16 \mathrm{ft}^{3} / \mathrm{s}$ or about $1.6 \mathrm{ft}^{3} / \mathrm{s}$ per river mile increase in streamflow during the 2010 period of record.

The continuous 2010 streamflow record illustrates the effects of irrigation withdrawals on streamflow in the upper watershed. Most of the available 2010 continuous record (April 1 through May 15 and from July 15 through September 30) indicated a net difference of about $25 \mathrm{ft}^{3} / \mathrm{s}$ between the main-stem outflow measured below Newlan Creek and the combined inflow of the upstream tributaries (fig. 16). These periods represent conditions prior to and after widespread flood irrigation withdrawals. Periods of substantial irrigation withdrawals were readily apparent in the streamflow record (fig.16), especially during a few days near the end of April and again during the last two weeks in May; consistent with typical periods of irrigation withdrawals for intensive flood and sprinkler irrigation. For example, a short-term period of intense irrigation withdrawals was observed on 4/30/2010 when $60 \mathrm{ft}^{3} / \mathrm{s}$ more tributary inflow was entering the upper watershed than was leaving it at the Smith River streamflowgaging station below Newlan Creek.

The continuous data not only represents the withdrawals from the Smith River during the irrigation season, but also the timing and magnitude of net irrigation return flows (irrigation and conveyance water that is not evaporated or consumed by plants that eventually returns to an aquifer or surface water). A period of intense irrigation withdrawal during the last two weeks in May was followed by a period (early June 2010 to mid-July 2010) with the largest net increase (an average of $71.1 \mathrm{ft}^{3} / \mathrm{s}$ ) in streamflow at the Smith River streamflow-gaging station below Newlan Creek relative to tributary inflow (fig. 16). This observation is likely due to increased groundwater discharge to the Smith River resulting from irrigation return flow. By late July, the apparent effects of return flows receded, and the net increase in streamflow measured below Newlan Creek returned to about $25 \mathrm{ft}^{3} / \mathrm{s}$. 

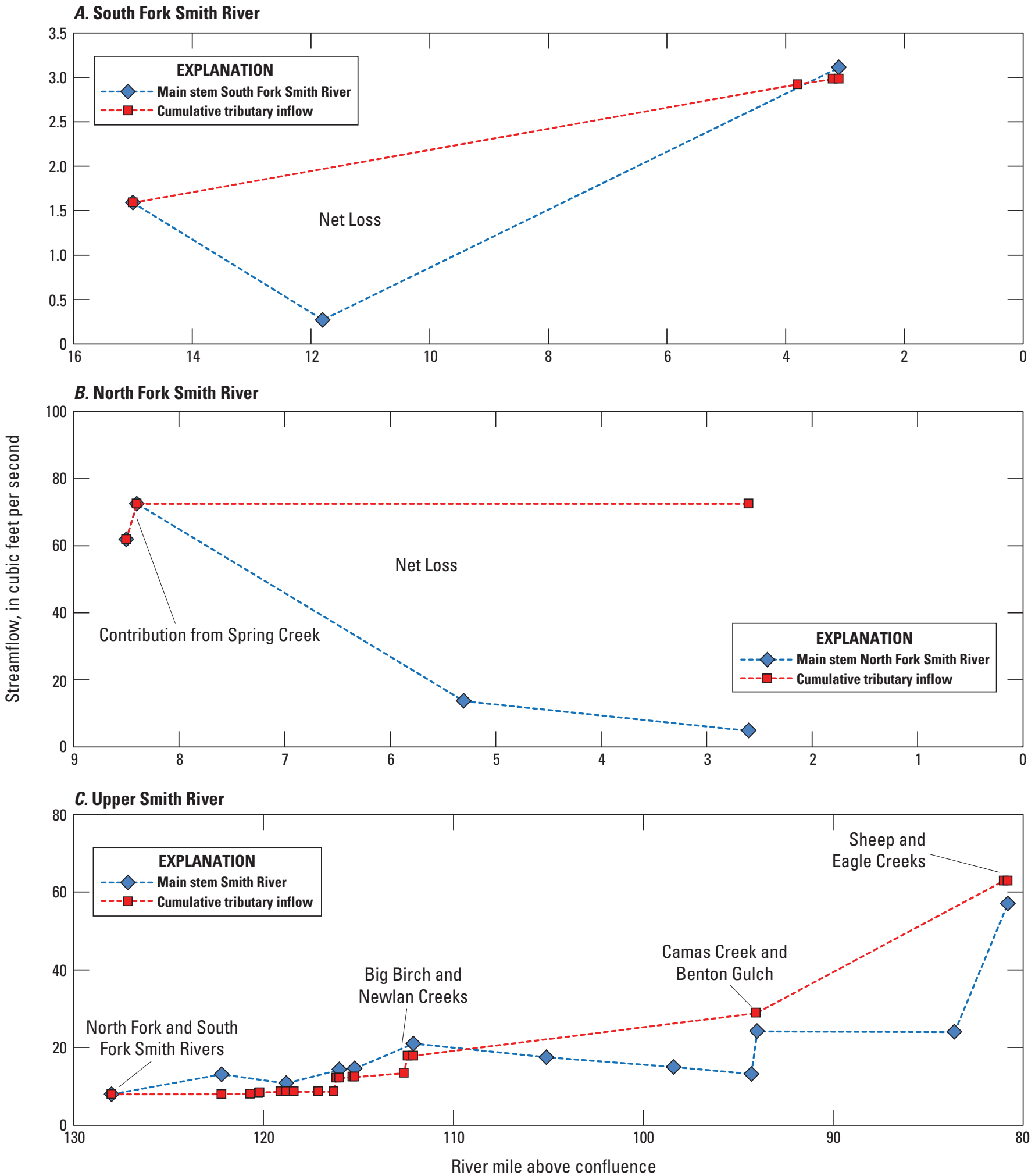

Figure 15. Instantaneous streamflow and cumulative tributary inflow of the $A$, South Fork Smith River; $B$, North Fork Smith River; and C, upper Smith River, Montana, August 1, 2007. 


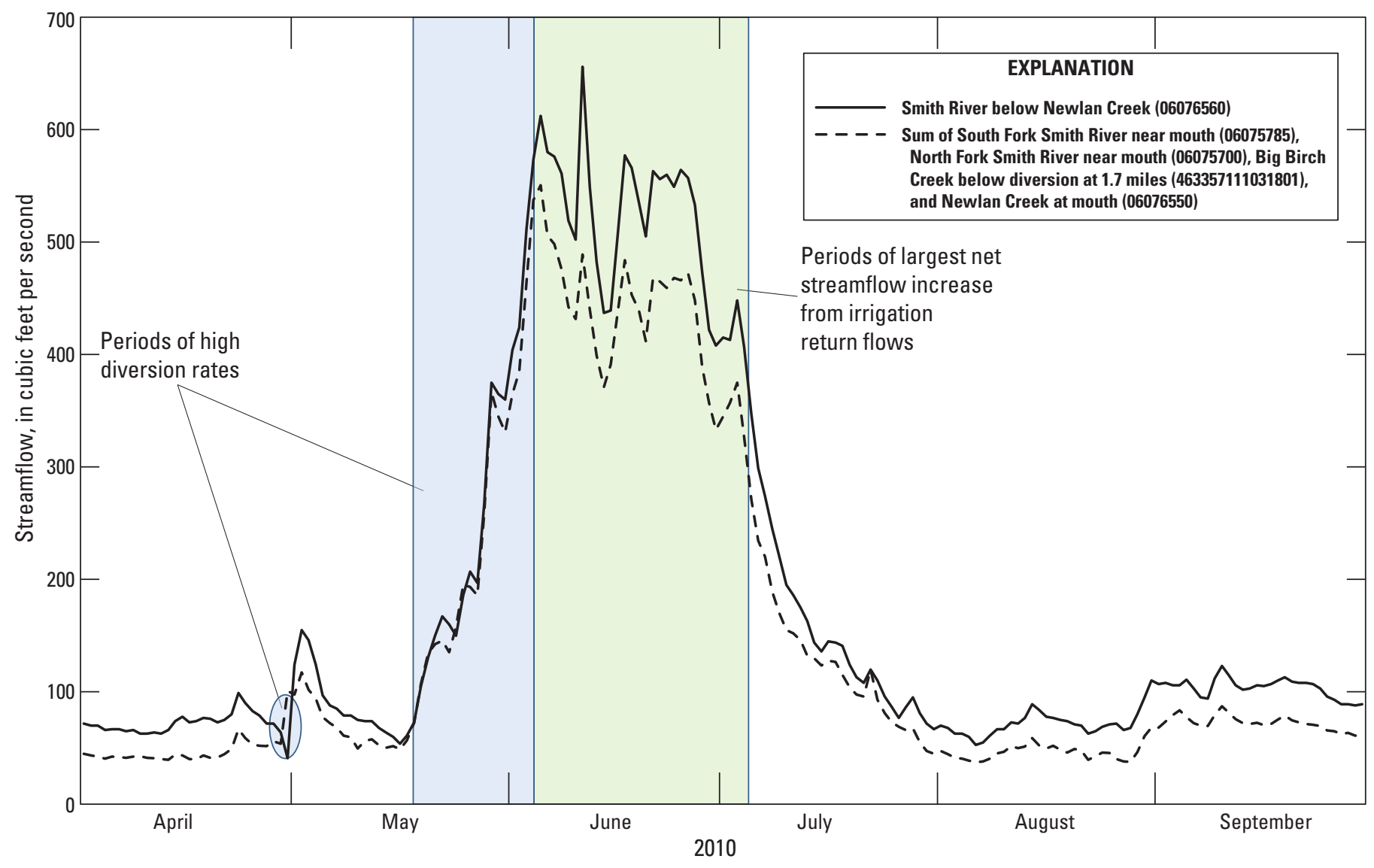

Figure 16. Streamflow at the Smith River below Newlan Creek streamflow-gaging station (station 06076560) and the combined streamflow of major tributaries in the upper Smith River watershed, Montana, April 2010 through September 2010.

\section{Qualitative Interpretation of Temperature and Water-Level Data}

Water-level and temperature data collected at the 10 groundwater and surface-water monitoring sites of the North and South Forks of the Smith River and the Smith River (fig. 8) were qualitative indicators of flow direction and magnitude. The observed data typically collected from late March to early November in 2007 and late March to early December 2008 indicated the presence of both losing and gaining stream reaches and dynamic changes in direction and magnitude with time.

Water temperatures in area streams typically ranged from 0 to over 25 degrees Celsius $\left({ }^{\circ} \mathrm{C}\right)$ annually primarily due to variations in air temperature. Daily temperatures in stream water temperatures varied more than $10^{\circ} \mathrm{C}$ during 24 -hour periods at some locations, apparently caused by diel changes in air temperature. Although groundwater is generally insulated from the daily air-temperature variation, temperatures in some shallow monitoring wells varied more than $5^{\circ} \mathrm{C}$ in a 24-hour period and some varied more than $15^{\circ} \mathrm{C}$ during the study period.
Depending on relative temperatures and volumes of exchanged water, the effects of groundwater inflow can be measureable in the stream temperature record. In the case of a gaining stream, groundwater inflow can measurably dampen and attenuate the diel temperature cycles in a stream. This condition is most apparent at the farthest downstream South Fork Smith River groundwater/surface-water monitoring site (station 06075785) with comparably dampened stream temperatures throughout the record and typically cooler temperatures than the upstream stations during the summer months (fig. 17). Stream temperatures at this site are cooler than the air temperature and the temperature measured in the shallow monitoring wells at the site, suggesting inflow of cooler, more regional groundwater at that location or upstream. Substantial groundwater inflows were not apparent in a review of continuous stream temperature data collected at other groundwater and surface-water monitoring sites (fig.8) as the stream temperature records followed similar trends to dampened air temperature (Nilges and Caldwell, 2012).

The altitudes of the stream stage and the groundwater levels at the 10 groundwater and surface-water monitoring sites were generally higher in 2008 than in 2007, coincident 


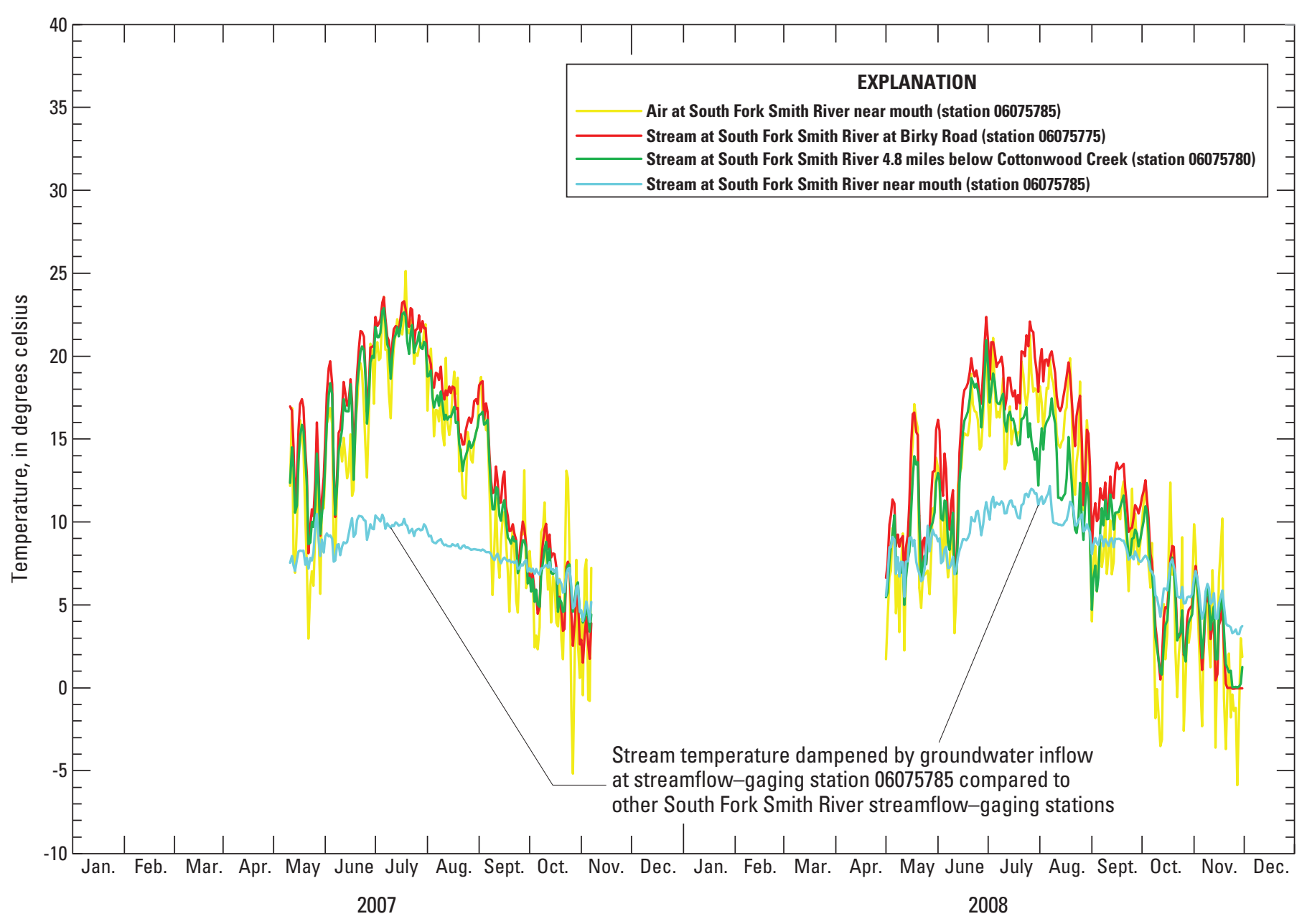

Figure 17. Water temperature at South Fork Smith River temporary streamflow-gaging stations and local air temperature, upper Smith River watershed, Montana, May 2007 through October 2007 and May 2008 through November 2008.

with higher precipitation values in 2008. Groundwater levels (Nilges and Caldwell, 2012) at the network sites typically were the highest in the late spring to early summer (late May through early July), fell during the summer (July to early August), and then recovered during the late summer through the fall. Many area wells at greater distances from the Smith River and its tributaries also showed similar trends (Nilges and Caldwell, 2012).

Increased recharge from snowmelt, local precipitation, high streamflow, and local flood irrigation at some locations likely caused the higher groundwater levels in the late spring or early summer. Summer declines in groundwater levels can be associated with reduced precipitation, local and regional effects of groundwater withdrawals, evapotranspiration (ET), and reduced streamflow and subsequent leakage in some area streams. Summer groundwater level declines ended during mid-August to mid-September at most sites, likely as a result of decreased groundwater use (irrigation), increased flow in losing streams, decreased ET, and the onset of local, latesummer flood irrigation which was noted at or near some sites. Of note, rising groundwater levels in late summer to early fall in near-stream wells corresponded with a decrease in nighttime air temperatures, which likely caused freezing of leaves on phreatophytes in the area (a killing frost), and reduced the consumption of groundwater by the plants.

Although differences in water levels (groundwater versus surface water) were small ( $0.03 \mathrm{ft}$ or less) and approached measurement uncertainty in some instances, most differences in groundwater levels and stream stage exceeded measurement uncertainty. Gradients between the stream and groundwater changed direction during the course of the study at six of the groundwater/surface-water monitoring sites. Hydraulic gradients between the groundwater and the stream indicated periods of potential streamflow gains (groundwater level higher than stream stage) and losses (groundwater level lower than stream stage). Groundwater levels in some wells installed in the streams were as much as $2 \mathrm{ft}$ higher or lower than stream stage.

The following sections provide descriptions and qualitative interpretation of the water-level and water-temperature data collected in 2007 and 2008 at the 10 groundwater/surface-water monitoring sites. Data from all monitoring sites are included in Nilges and Caldwell (2012). 
South Fork Smith River at Birky Road (Groundwater and Surface-Water Monitoring Site 1)

A strong and dynamic connection between groundwater and surface water was observed at the South Fork Smith River at Birky Road (1.6 mi below Cottonwood Creek) and a single monitoring well (SF0606B) installed in the center of the stream (station 06075775, site 1 on fig. 8). Stable to gaining conditions were apparent in the spring and fall of both 2007 and 2008 as groundwater levels were near or above stream stage (figs. $18 A$ and $B$ ). Losing conditions became apparent as groundwater levels fell below stream stage during the summer months of both years (figs. $18 A$ and $B$ ); groundwater levels declined to $0.54 \mathrm{ft}$ below the stream stage during mid-summer 2007 and declined to $0.37 \mathrm{ft}$ below stream stage in 2008 .

Losing conditions during the summer months were also identified by using heat as tracer (temperature measured in and below the stream). Temperatures measured below the streambed resembled dampened stream temperatures (fig. $18 C$ and $D$ ). The infiltration of stream water to a depth of at least $2.89 \mathrm{ft}$ (the depth of the deepest thermistor) was apparent as temperatures measured at that depth closely matched the trend of the stream at the shallow thermistor.

\section{South Fork Smith River 4.8 Miles below Cottonwood Creek (Groundwater and Surface- Water Monitoring Site 2)}

Dynamic changes between gaining and losing conditions were exhibited at the South Fork Smith River 4.8 mi below Cottonwood Creek and a single monitoring well (SF0605) installed in the center of the stream (station 06075780, site 2 on fig. 8). Coincident with the timing of local flood irrigation (during the spring of both 2007 and 2008), groundwater levels rose to the point where water was flowing out of the top of the well with measured groundwater altitudes of up to $0.7 \mathrm{ft}$ higher than stream stage (fig. $19 A$ and 19B). During the summer months of both years, the gradient reversed and groundwater levels dropped below stream stage and at times groundwater levels declined to $1.3 \mathrm{ft}$ below the bottom of the streambed. Periods where groundwater levels dropped below the bottom of the streambed indicate a possible disconnection (unsaturated conditions) between the stream and the water table. Streamflow was less than $1 \mathrm{ft}^{3} / \mathrm{s}$ for most of July and August, 2007. This part of the stream went dry during July and August of 2008, thus classifying this tributary as intermittent. The presence of water in the stream during periods of potentially unsaturated conditions below the stream indicates the presence of low permeability streambed sediments at this location. Once disconnected the water table and the stream stage can act independently of one another. Groundwater levels rebounded late in both summers to levels higher than stream stage in 2007 and close to stream stage (typically less than 0.3 $\mathrm{ft}$ below stream stage) in 2008 .
The thermal record at this site supports limited exchange (flow) between the stream and the underlying aquifer. Losing conditions during the summer were consistent with temperatures measured at $1.48 \mathrm{ft}$ below the streambed that followed the general trend of temperatures measured in the stream (fig. $19 C)$. The deeper thermistor $(2.98 \mathrm{ft}$ below the stream bottom) was often cooler with very little diel variation (fig. 19D). As groundwater levels fell below the streambed (possible unsaturated conditions), the diel temperature fluctuations were reduced. Therefore, although water levels point to leakage from the stream during the summer months, the limited diel variation in the thermal signal measured below the stream indicated limited connection between the stream and groundwater during losing conditions.

\section{South Fork Smith River near Mouth (Groundwater and Surface-Water Monitoring Site 3)}

Groundwater discharge to the stream was evidenced by both water-level and temperature data throughout the entire record at the South Fork Smith River near mouth (station 06075785; site 3, fig. 8). During both years (2007 and 2008), groundwater levels measured in the four monitoring wells (fig. 20) were generally $1.0 \mathrm{ft}$ higher than stream stage (Nilges and Caldwell, 2012). Groundwater levels were the highest during the late spring to early summer periods of high streamflow and flood irrigation (fig. 21A). Although stream stage remained relatively constant through the summer and early fall, groundwater levels declined during most of the summer. Groundwater levels began rising during mid-August to mid-September resulting in increased hydraulic gradients from groundwater to surface water (fig $21 A$ and $21 B$ ). This late summer rise in groundwater levels is likely the result of a combination of factors including decreased evapotranspiration (Bureau of Reclamation, 2007 and 2008), local recharge from late season flood irrigation in the area, and/or reduction in groundwater withdrawals for irrigation.

Stream temperatures were dramatically influenced by groundwater discharge at this site. Temperature variations measured in and below the stream were reduced compared to other monitored locations (Nilges and Caldwell, 2012). Stream temperatures tracked closely with the temperatures measured below the streambed and were dampened compared to air temperature (fig. $21 C$ and $21 D$ ). This suggests that discharge of groundwater of relatively stable temperature (cooler in the summer), and possibly following a more regional flow path, affected the stream temperature at this station. Temperatures also indicate the relative contribution of groundwater inflow in relation to the overall streamflow at this location. The largest diel variation in stream water temperature, probably most affected by air temperature, occurred during periods of relatively high streamflow in the spring to early summer in both 2007 and 2008. The diel variation was noticeably reduced during the remaining record. Groundwater inflow likely influences temperatures to a greater degree during these periods of 

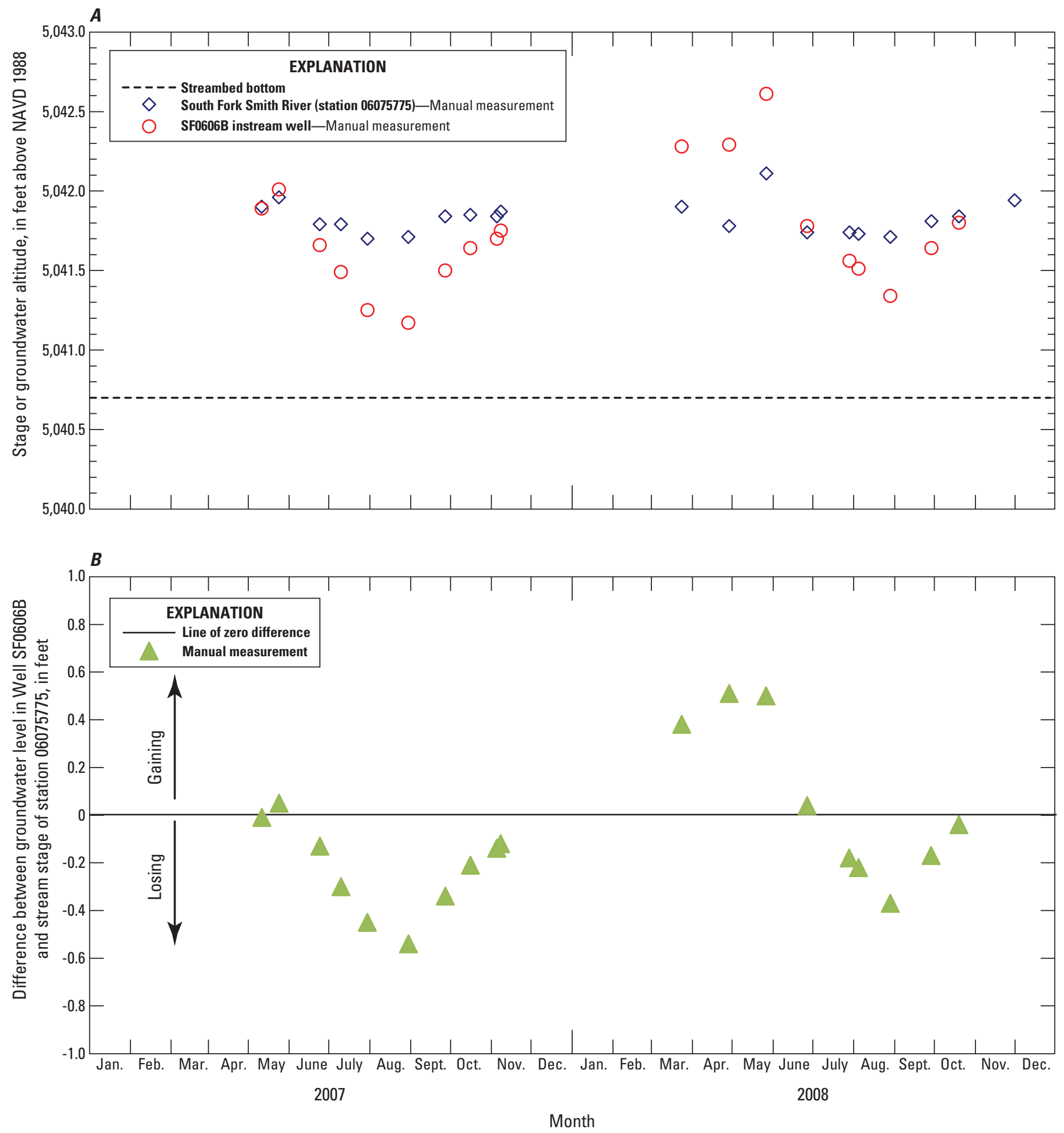

Figure 18. Data collected at the South Fork Smith River at Birky Road monitoring site (station 06075775). A, Altitude of stream stage and groundwater at well SF0606B; $B$, Difference in head between the groundwater at well SF0606B and stream; $C$, Hourly temperature of stream at station and in monitoring well SF0606B at depths of 1.39 feet and 2.89 feet below the streambed; and $D$, Diel temperature variation in monitoring well SF0606B at depths of 1.39 feet and 2.89 feet below the streambed, May 2007 through November 2007 and March 2008 through December 2008. 

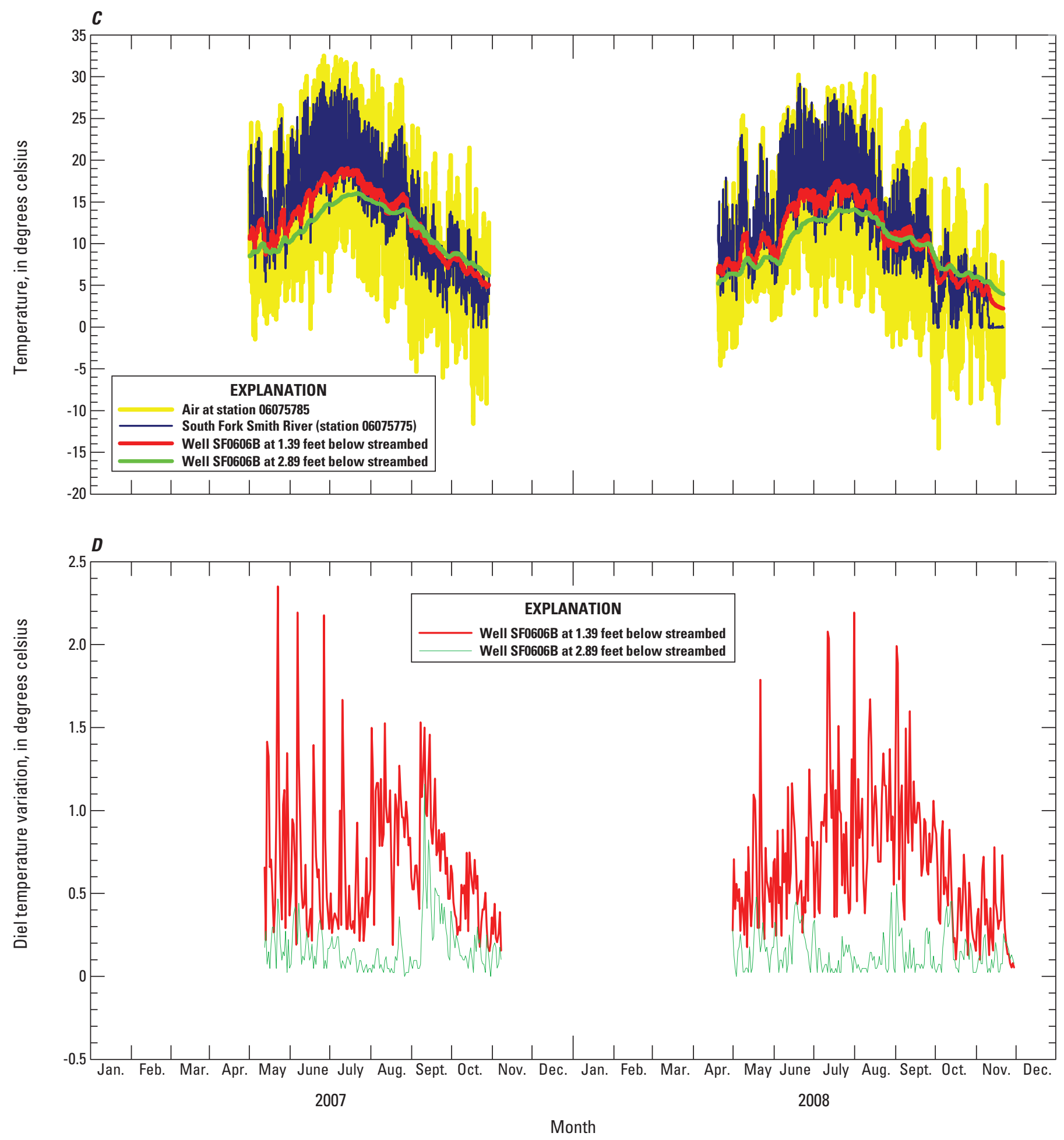

Figure 18. Data collected at the South Fork Smith River at Birky Road monitoring site (station 06075775). A, Altitude of stream stage and groundwater at well SF0606B; $B$, Difference in head between the groundwater at well SF0606B and stream; $C$, Hourly temperature of stream at station and in monitoring well SF0606B at depths of 1.39 feet and 2.89 feet below the streambed; and $D$, Diel temperature variation in monitoring well SF0606B at depths of 1.39 feet and 2.89 feet below the streambed, May 2007 through November 2007 and March 2008 through December 2008.-Continued. 

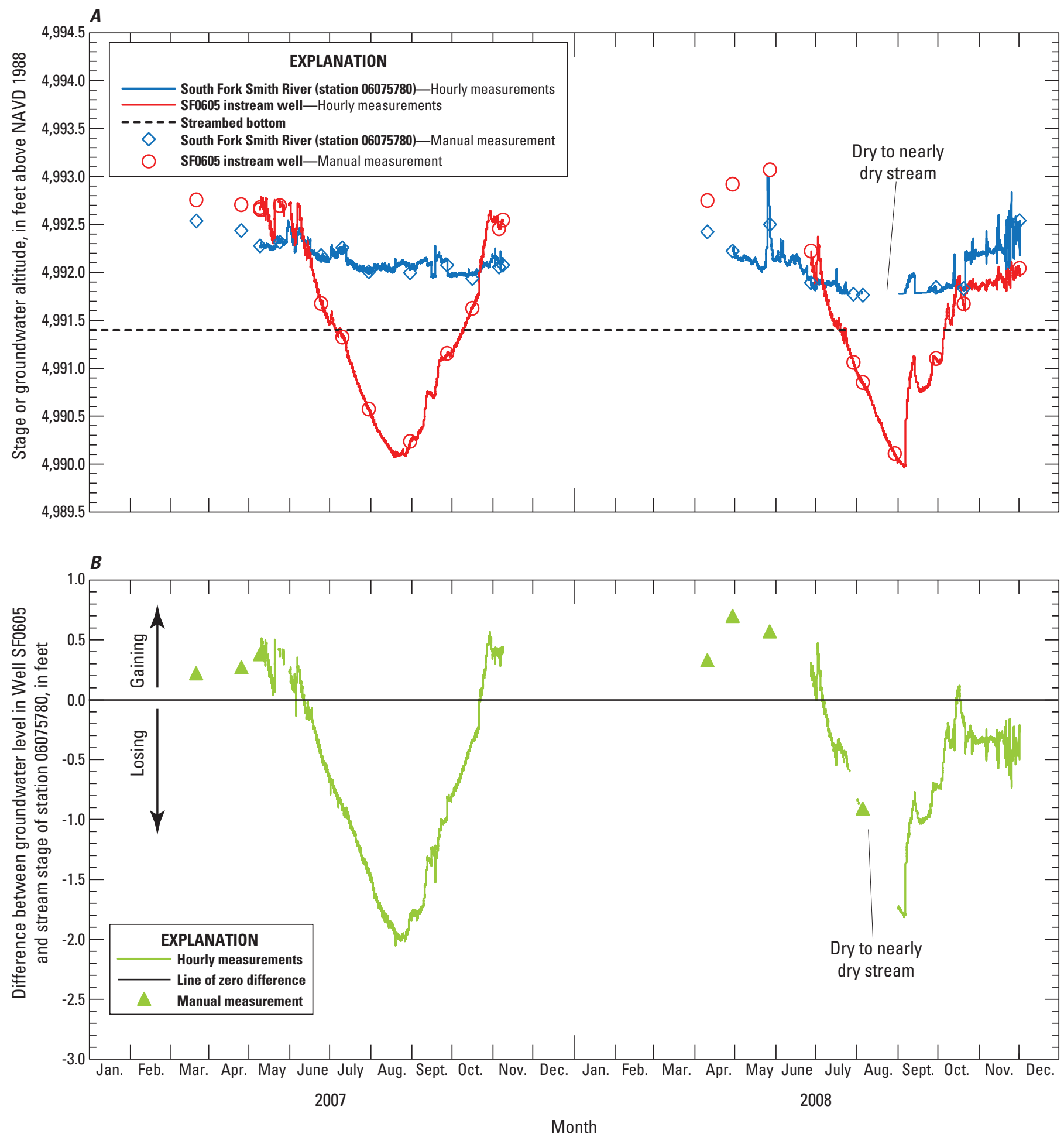

Figure 19. Data collected at the South Fork Smith River monitoring site (station 06075780) 4.8 mi below Cottonwood Creek. $A$, Altitude of stream stage and groundwater at well SF0605; $B$, Difference in hydraulic head between groundwater and stream; $C$, Hourly temperature measurements of air at station 06075785, in stream at the South Fork Smith River (station 06075780), and in monitoring well SF0605 at depths of $1.48 \mathrm{ft}$ and $2.98 \mathrm{ft}$ below the streambed; and D, Diel temperature variation in monitoring well SF0605 at depths of $1.48 \mathrm{ft}$ and 2.98 ft below the streambed, March 2007 through November 2007 and April 2008 through December 2008. 

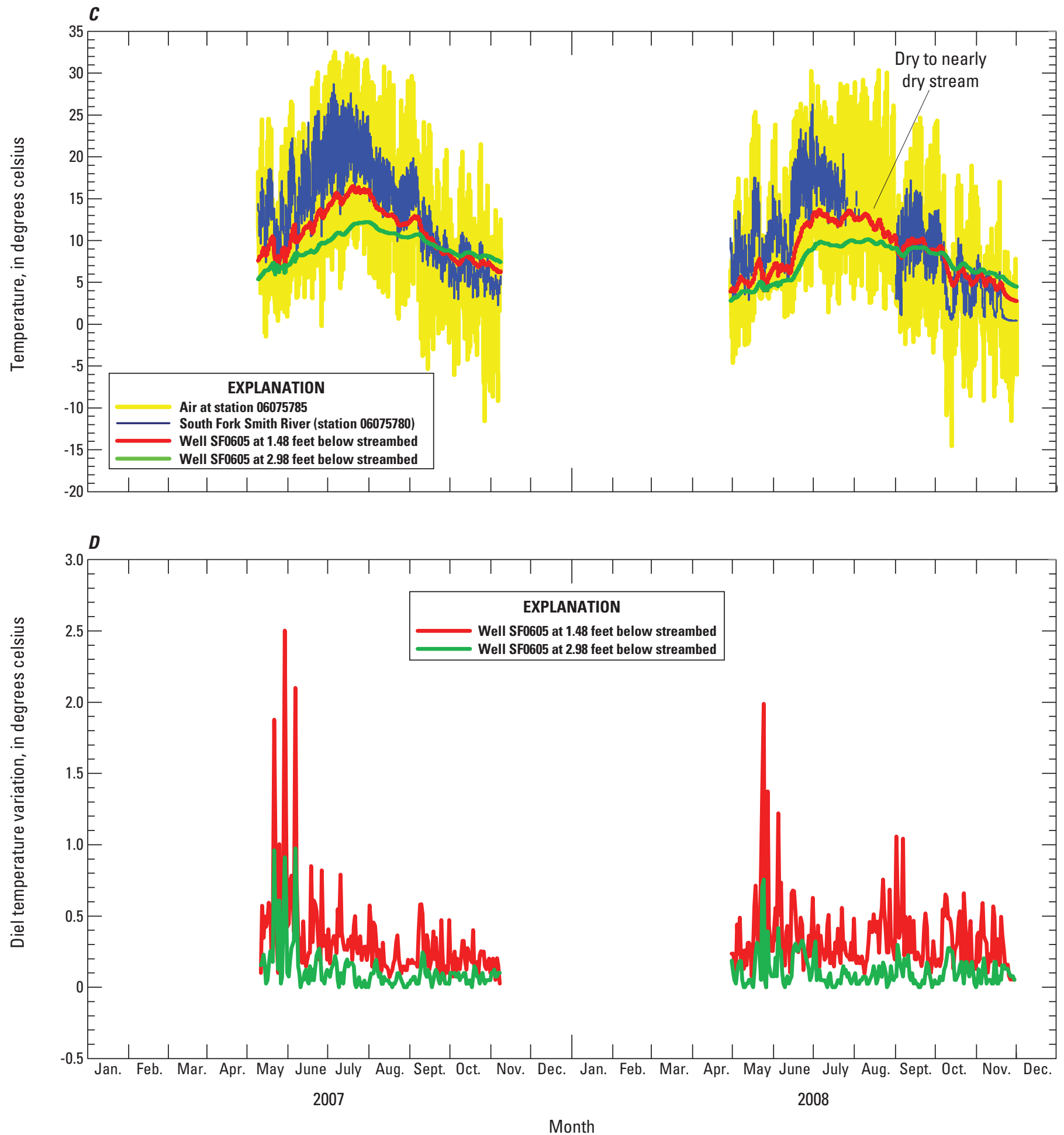

Figure 19. Data collected at the South Fork Smith River monitoring site (station 06075780) 4.8 mi below Cottonwood Creek. $A$, Altitude of stream stage and groundwater at well SF0605; $B$, Difference in hydraulic head between groundwater and stream; $C$, Hourly temperature measurements of air at station 06075785, in stream at the South Fork Smith River (station 06075780), and in monitoring well SF0605 at depths of $1.48 \mathrm{ft}$ and $2.98 \mathrm{ft}$ below the streambed; and D, Diel temperature variation in monitoring well SF0605 at depths of $1.48 \mathrm{ft}$ and 2.98 $\mathrm{ft}$ below the streambed, March 2007 through November 2007 and April 2008 through December 2008.—Continued 


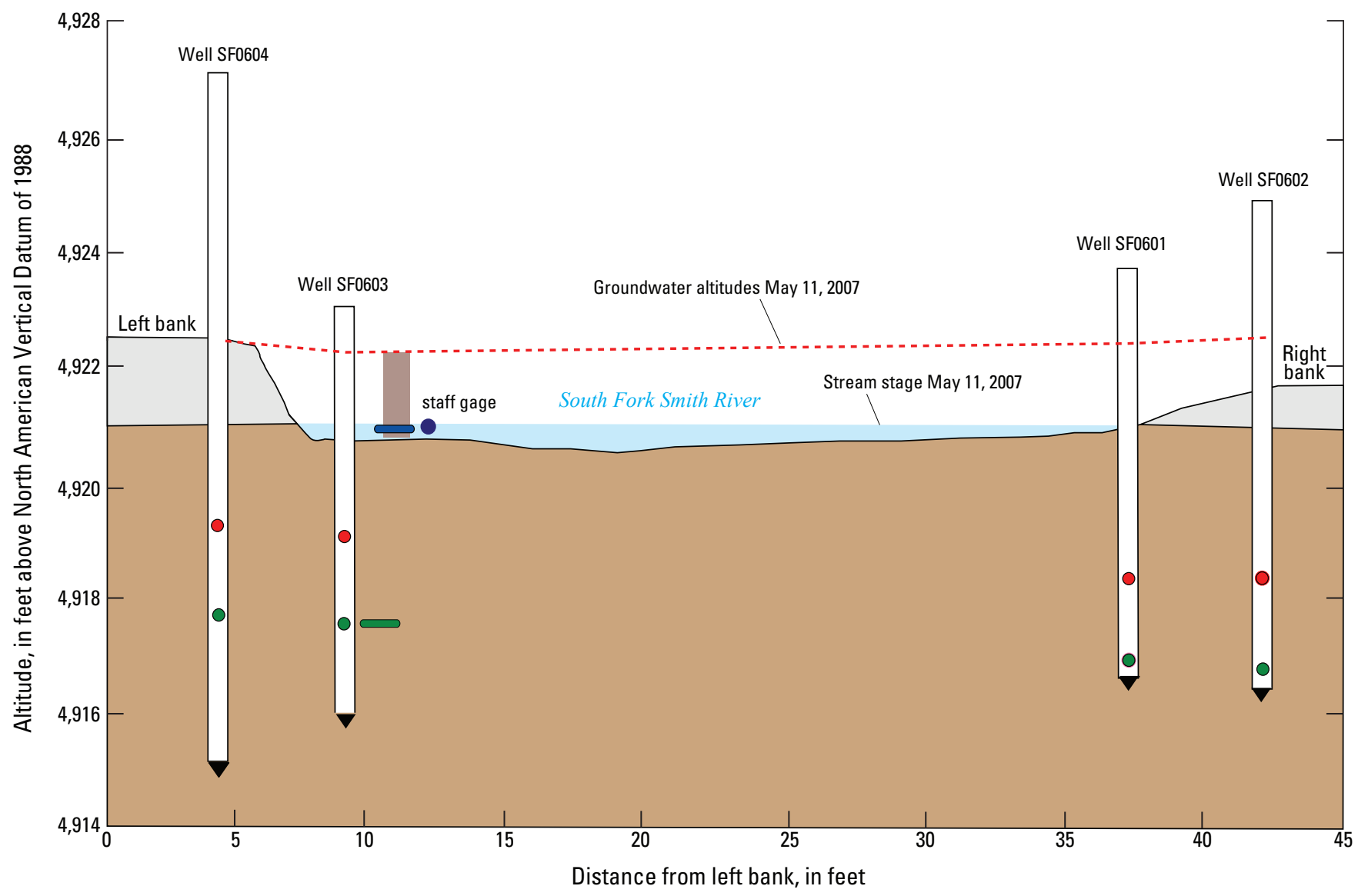

EXPLANATION

\begin{tabular}{|c|c|c|}
\hline & Soil & Instrument type \\
\hline & $\begin{array}{l}\text { Quaternary alluvium-Shallow } \\
\text { near-streambed sediments }\end{array}$ & $\begin{array}{l}\text { Thermistor } \\
\text { Upper instrumentation in } \\
\text { monitoring well }\end{array}$ \\
\hline Well SFO601 & $\begin{array}{l}\text { Groundwater altitudes-Inferred } \\
\text { between wells }\end{array}$ & $\begin{array}{l}\text { - Lower instrumentation in } \\
\text { monitoring well } \\
\text { - Stream instrumentation }\end{array}$ \\
\hline ו & $\begin{array}{l}\text { Monitoring well and identifier- } \\
\text { Perforated near bottom }\end{array}$ & $\begin{aligned} & \text { Pressure transducer } \\
& \text { Monitoring well installation } \\
& \text { Stream instrumentation }\end{aligned}$ \\
\hline
\end{tabular}

Figure 20. Channel geometry, monitoring well network, and thermistor and/or pressure transducer locations at South Fork Smith River near mouth monitoring site (station 06075785). Groundwater altitudes and stream stage for May 11, 2007. 

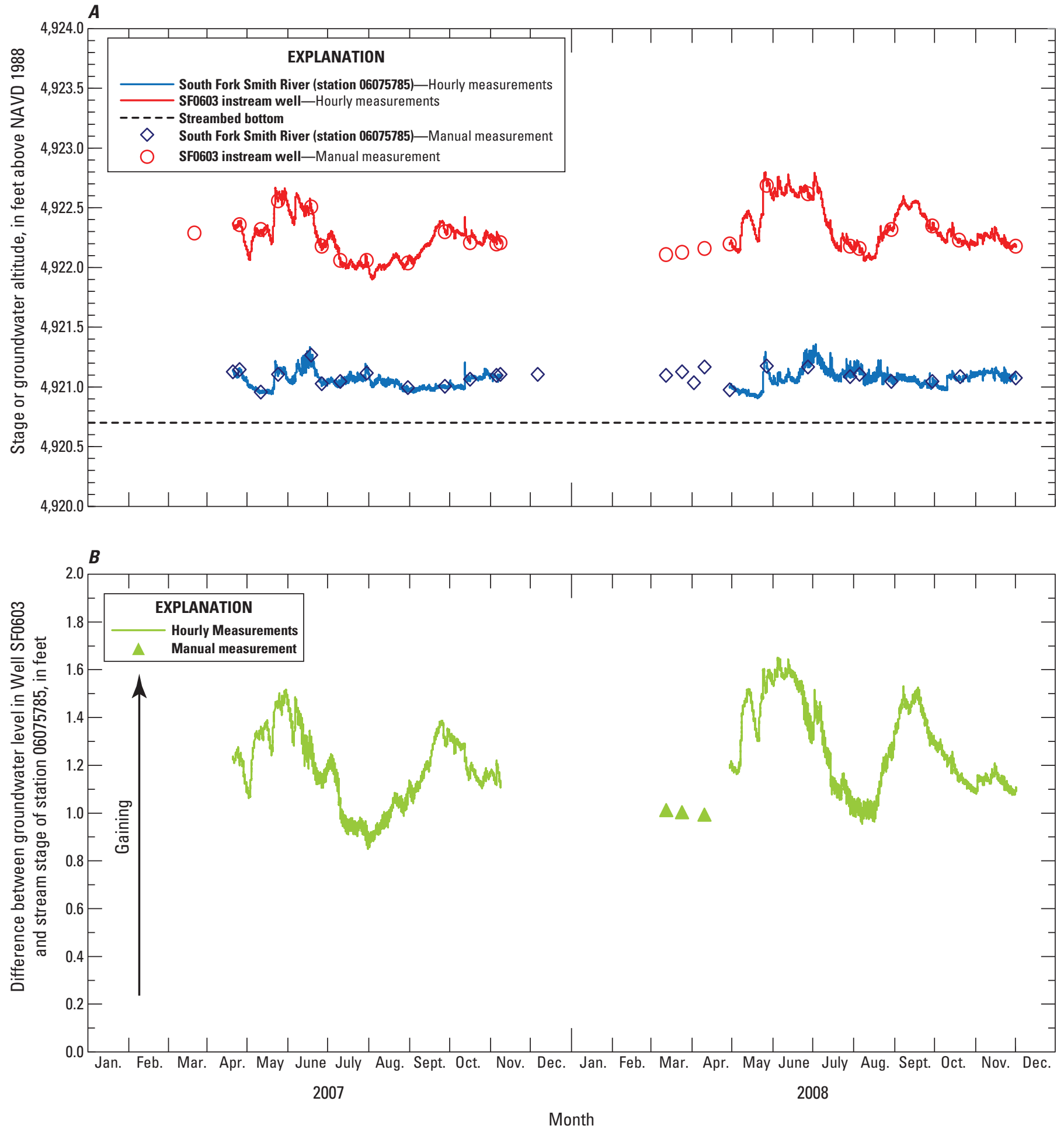

Figure 21. Data collected at the South Fork Smith River near mouth monitoring site (station 06075785). $A$, Altitude of stream stage and groundwater at well SF0603; $B$, Difference in hydraulic head between the groundwater at well SF0603 and stream; $C$, Hourly temperature measurements of air at station 06075785, stream at station 06075785, in monitoring well SF0603 at depths of $1.65 \mathrm{ft}$ and $3.15 \mathrm{ft}$ below the streambed; and D, Diel temperature variation in monitoring well SF0603 at depths of $1.65 \mathrm{ft}$ and $3.15 \mathrm{ft}$ below the streambed, March 2007 through December 2007 and March 2008 through December 2008. 

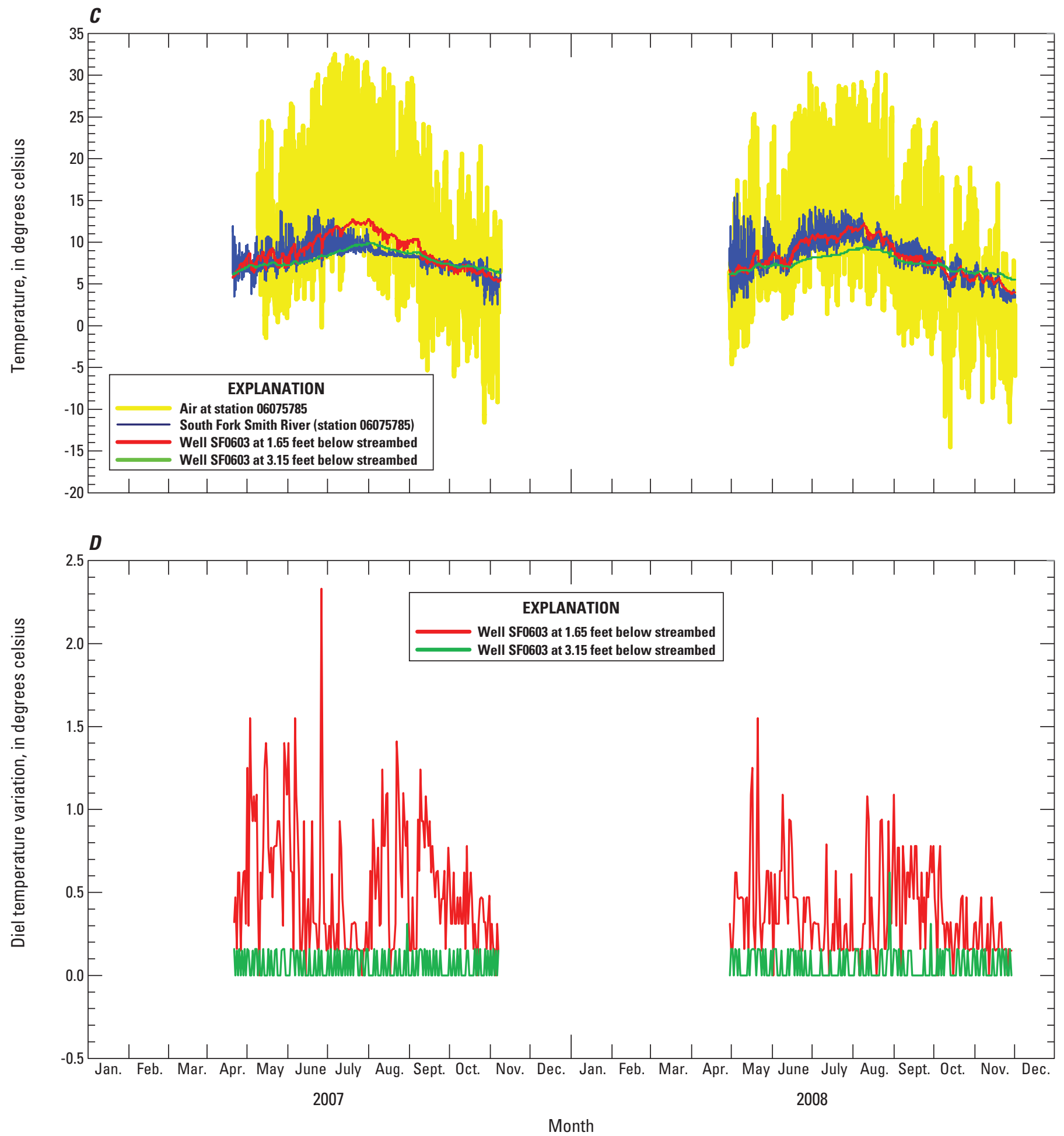

Figure 21. Data collected at the South Fork Smith River near mouth monitoring site (station 06075785). $A$, Altitude of stream stage and groundwater at well SF0603; B, Difference in hydraulic head between the groundwater at well SF0603 and stream; $C$, Hourly temperature measurements of air at station 06075785, stream at station 06075785, in monitoring well SF0603 at depths of $1.65 \mathrm{ft}$ and $3.15 \mathrm{ft}$ below the streambed; and $D$, Diel temperature variation in monitoring well SF0603 at depths of $1.65 \mathrm{ft}$ and $3.15 \mathrm{ft}$ below the streambed, March 2007 through December 2007 and March 2008 through December 2008.—Continued. 
reduced streamflow because groundwater is responsible for a larger percentage of total streamflow. This is especially apparent in the mid-summer 2007 for temperatures measured at $3.15 \mathrm{ft}$ below the stream bottom in well SF0603, which tracks very closely with the measured stream temperature (fig. 21C).

\section{North Fork Smith River near Mouth (Groundwater and Surface-Water Monitoring Site 4)}

Losing conditions were predominant at the North Fork Smith River near the mouth (station 06075700 , site 4 on fig. 8). During the majority of both years, groundwater levels measured in the four monitoring wells (fig. 22) were below stream stage (Nilges and Caldwell, 2012). During the late spring to early summer periods of high streamflow and local flood irrigation, groundwater altitudes nearly equaled the stream stage (fig. 23A and 23B) (hydraulic gradients approached zero). Unsaturated conditions occurred as groundwater levels declined to $1.0 \mathrm{ft}$ or more below the streambed during the summer months. However, groundwater levels were measured at or near the stream banks, and the hydraulic connection between the stream and the groundwater in the middle of the cross section was unmeasured. The hydraulic gradient from the stream to the groundwater increased during the summer months as the groundwater levels declined with relatively little variation in stream stage. Although decreased stream leakage may contribute to the declining groundwater levels during this period, the relatively stable stream stage indicates that other factors such as reduced recharge from discontinued local flood irrigation, increased groundwater withdrawal through wells, and increased ET contributed to the declining groundwater levels during the summer. Groundwater levels began rising during mid-August to mid-September and approached or exceeded stream-stage during the fall of both years. Again, stream stage remained relatively constant, an indication that other contributing factors in addition to stream leakage such as reduced rates of ET and groundwater use affected the groundwater levels.

Rapid changes in the water levels illustrated the dynamic interaction of groundwater and surface water at this site, particularly evident during the late fall of both 2007 and 2008 (fig. 23A). The North Fork Smith River was temporarily diverted upstream from the gage and the stream nearly went dry during construction of a downstream bridge in October 2007 causing groundwater levels to drop $0.3 \mathrm{ft}$ (well NF0602) in 13 hours. Groundwater levels rebounded when flow in the North Fork Smith River returned. During October 2008, debris on a downstream culvert caused backwater and the stream stage to increase by $1.6 \mathrm{ft}$, followed by a sudden release that resulted in a rapid $2.0 \mathrm{ft}$ decline in stream stage. Although groundwater level altitudes increased with the increasing stream stage, the sudden decline in stream stage after the debris was removed caused a dramatic gradient reversal (from a losing reach to a gaining reach) as the stream stage dropped faster than the groundwater level (fig. $23 A$ and 23B).
Losing conditions were also supported by using heat as a tracer as temperatures below the stream (fig. 23C) followed a slightly dampened seasonal and diel trend observed in the stream (indicative of advective flow of heat from the stream to the groundwater). Temperatures measured below the streambed may also be affected by unsaturated conditions at times. The infiltration of stream water was apparent, as temperatures measured at depths of nearly $3.0 \mathrm{ft}$ below the streambed resembled those of the stream (example; well NF0602, fig. 23C). Temperatures in the monitoring wells at or near the right bank (NF0601 and NF0602) during the late April to late August were more dynamic and values resemble the surface water more than the left bank wells (NF0603 and NF0604) (Nilges and Caldwell, 2012). This greater similarity of the right bank monitoring wells to the stream potentially indicates (1) a greater quantity of water moving from the stream to the right bank side than to the left bank side or (2) reduced thermal conductance near the left bank because of unsaturated conditions.

\section{Smith River below North Fork Smith River (Groundwater and Surface-Water Monitoring Site 5)}

Slightly gaining conditions and the occurrence of local recharge from flood irrigation were apparent at the Smith River below North Fork Smith River (station 06075810; site 5 on fig. 8). Groundwater levels from all five wells at this site (fig. 9) followed the general trend of the stream stage, but were higher than stream stage in nearly all instances (Nilges and Caldwell, 2012). Groundwater levels in well SR0616 ranged from 0.06 to $0.28 \mathrm{ft}$ higher than stream stage with a median of $0.11 \mathrm{ft}$ in (fig. $24 A$ and $24 B$ ). Groundwater altitudes were the highest during the late spring-early summer periods of high streamflow and in the early fall. The largest measured gradient from groundwater to the stream at well SR0616 occurred May 24, 2007 (0.25 ft) and June 27, 2008 (0.28 ft). Both of these events occurred during periods of local flood irrigation, which likely caused a rise in local groundwater levels due to increased groundwater recharge.

Consistent with a gaining reach, temperatures measured beneath the stream in the four instrumented wells were typically cooler than the stream and showed limited diel fluctuation for most of the record (Nilges and Caldwell, 2012). Beginning in August of both years, temperatures beneath the streambed tracked more closely to stream temperatures and showed more diel fluctuation (fig. $24 C$ and $24 D$ ), although observed hydraulic head gradients continued to indicate flow from the groundwater to the stream. Late season temperatures may indicate (1) a period of reduced groundwater discharge with temperatures below the streambed becoming more affected by the conduction of heat from the stream through the streambed or (2) a period of increased groundwater discharge of a localized flow system rather than groundwater of a moreregional flow system. Shallow groundwater of a localized flow 


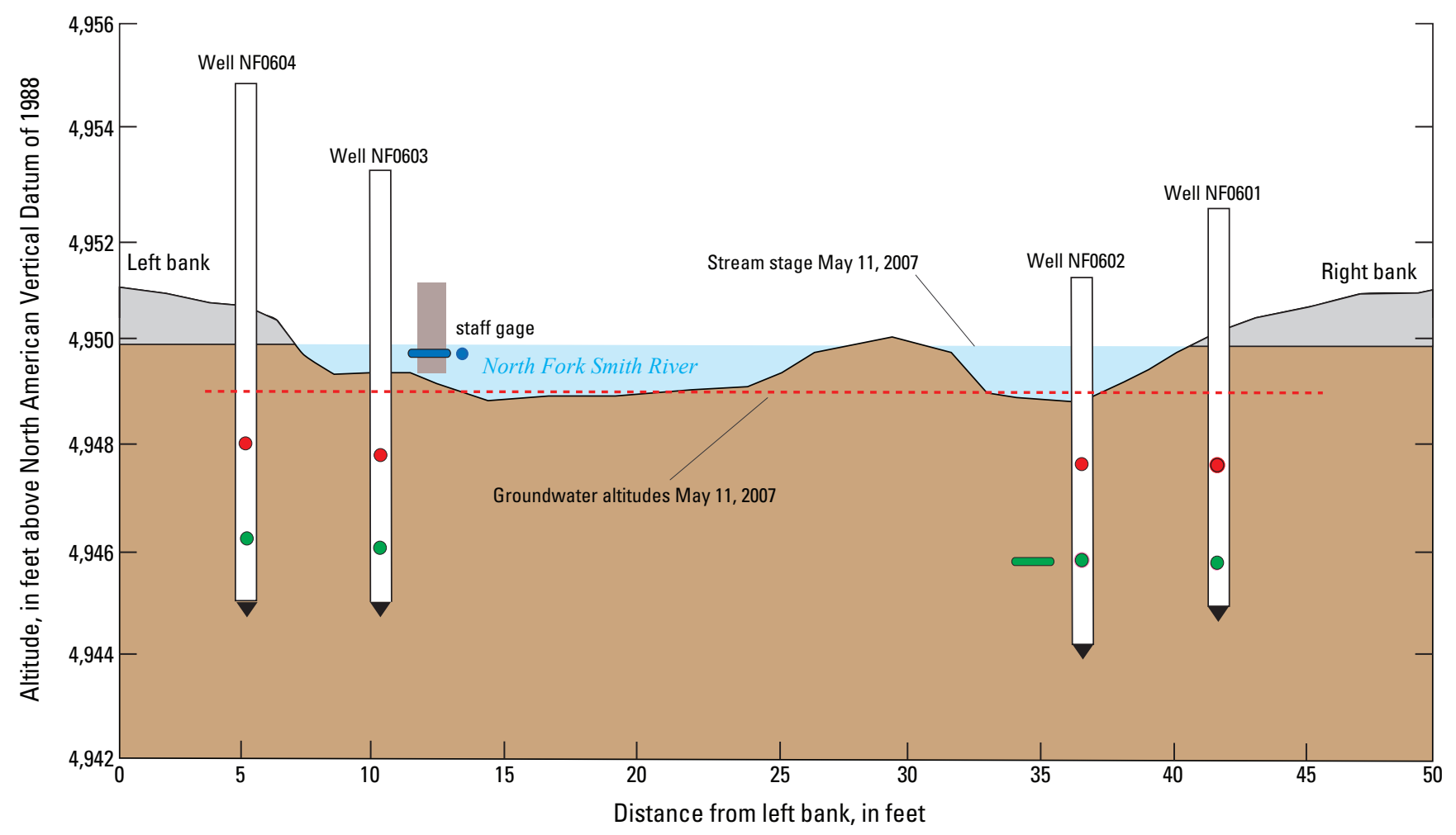

EXPLANATION

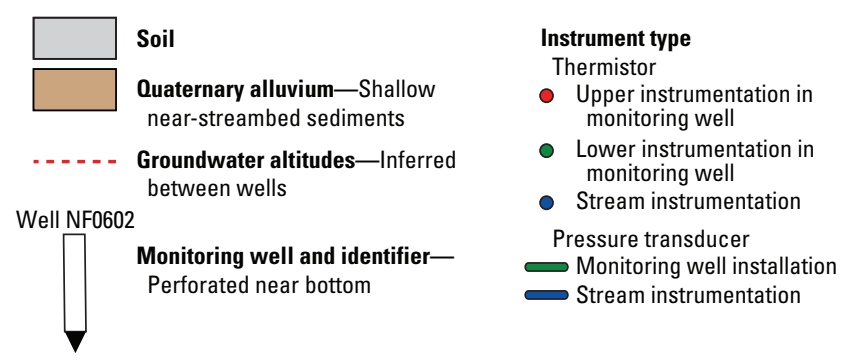

Figure 22. Channel geometry, monitoring well network, and thermistor and/or pressure transducer locations at North Fork Smith River near mouth monitoring site (station 06075700). Groundwater altitudes and stream stage for May 11, 2007.

system (for example, groundwater recharged during local, lateseason flood irrigation) would likely have more temperature fluctuation than groundwater of a more regional system.

\section{Smith River at Birch Creek Road and Smith River below Woods Gulch (Groundwater and Surface- Water Monitoring Sites 6 and 7)}

Dominant flow to or from the stream was not apparent at the single instream well (SR06B) at Smith River at Birch Creek Road (site 6 on fig. 8) and two instream wells (SR0612 and SR0613) at the Smith River below Woods Gulch (site 7 on fig. 8). Data from the Smith River at Birch Creek Road (station 463257111002801) (Nilges and Caldwell, 2012) indicated that the site was neither strongly gaining nor losing during the period of record as the measured hydraulic gradient was oftentimes within measurement uncertainty. Temperatures from the single monitoring well tracked very closely to that of the stream and showed diel variation consistent with a losing reach or conductive heat flow in a slightly gaining reach.

Data from the Smith River below Woods Gulch (station 463270111011401) (Nilges and Caldwell, 2012) indicated that the site was slightly losing during most of the period of record. The measured hydraulic gradient consistently showed a slight loss with groundwater levels typically less than $0.1 \mathrm{ft}$ below the stream stage. Temperature measured in the monitoring wells below the streambed tracked very closely with the stream temperature and showed diel variation consistent with a losing reach. 

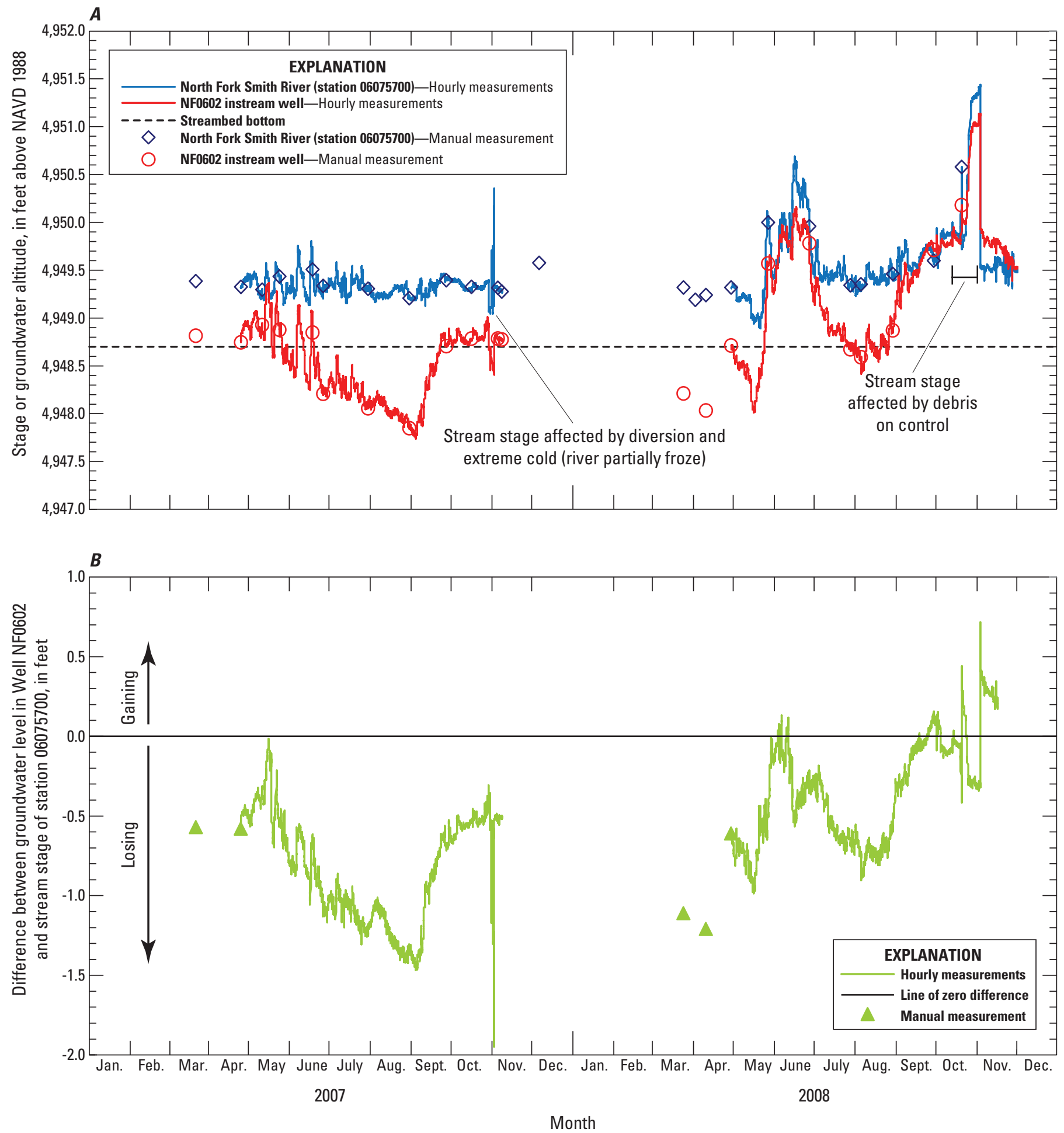

Figure 23. Data collected at the North Fork Smith River near mouth monitoring site (station 06075700). A, Altitude of stream stage and groundwater at well NF0602; $B$, Difference in hydraulic head between the groundwater at well NF0602 and stream; $C$, Hourly temperature measurements of air at station 06075785, stream at station 06075700, and in monitoring well NF0602 at depths of $1.42 \mathrm{ft}$ and $2.92 \mathrm{ft}$ below the streambed; and D, Diel temperature variation in monitoring well NF0602 at depths of $1.42 \mathrm{ft}$ and $2.92 \mathrm{ft}$ below the streambed, March 2007 through December 2007 and March 2008 through December 2008. 

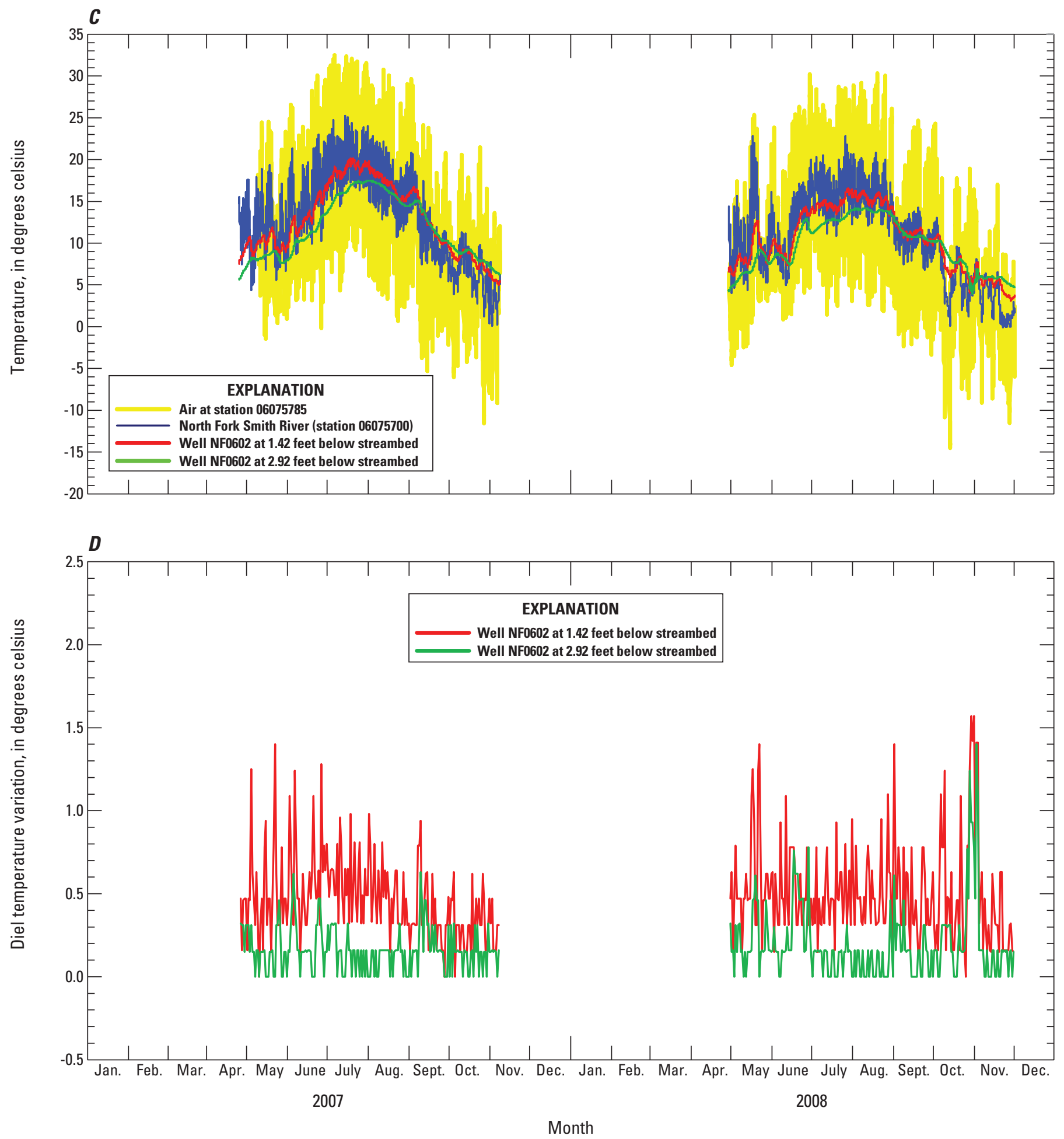

Figure 23. Data collected at the North Fork Smith River near mouth monitoring site (station 06075700). $A$, Altitude of stream stage and groundwater at well NF0602; $B$, Difference in hydraulic head between the groundwater at well NF0602 and stream; $C$, Hourly temperature measurements of air at station 06075785, stream at station 06075700, and in monitoring well NF0602 at depths of $1.42 \mathrm{ft}$ and $2.92 \mathrm{ft}$ below the streambed; and $D$, Diel temperature variation in monitoring well NF0602 at depths of $1.42 \mathrm{ft}$ and $2.92 \mathrm{ft}$ below the streambed, March 2007 through December 2007 and March 2008 through December 2008.—Continued 

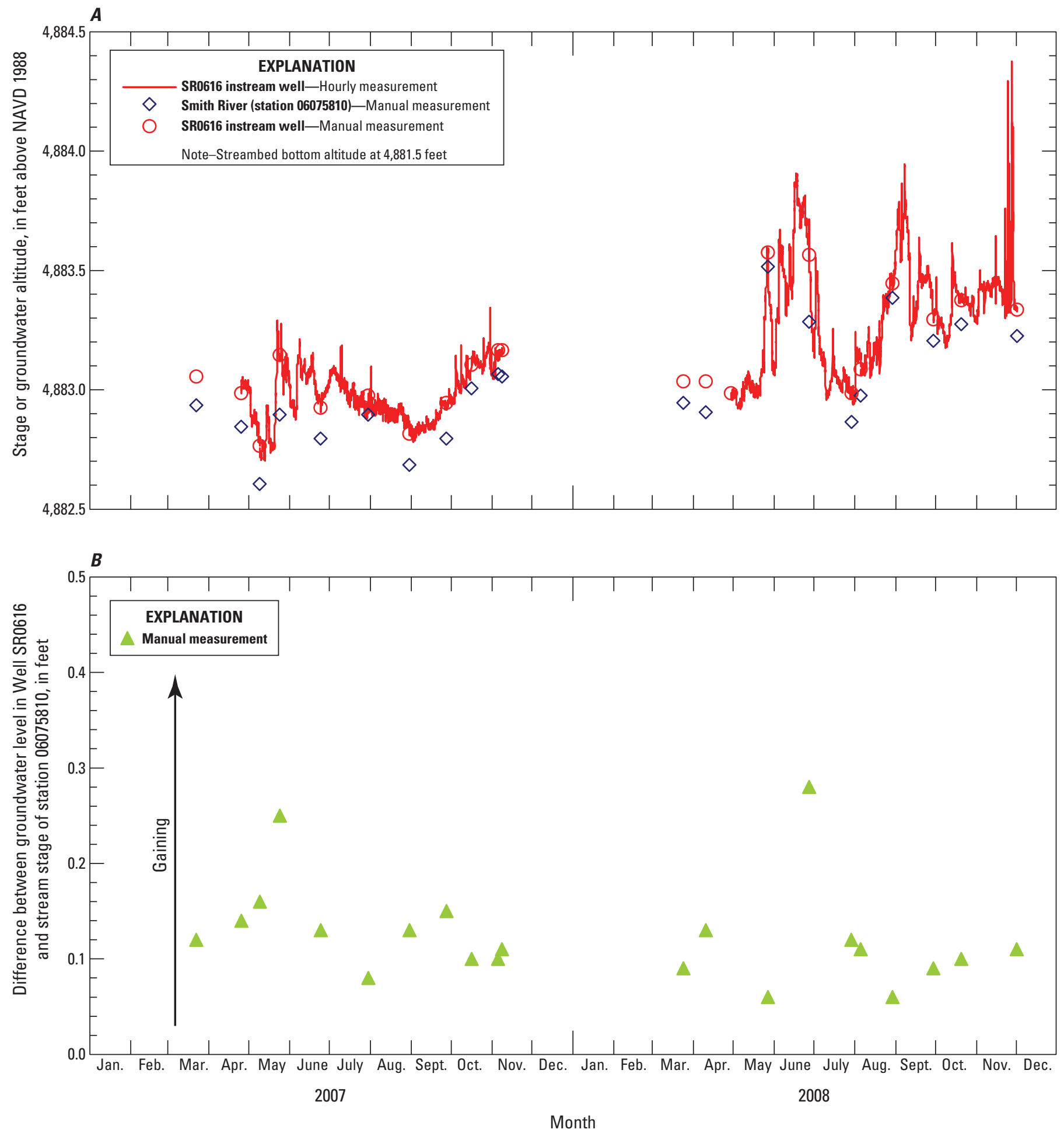

Figure 24. Data collected at the Smith River below North Fork Smith River monitoring site (station 06075810). A, Altitude of stream stage and groundwater at well SR0616; $B$, Difference in hydraulic head between groundwater at well SR0616 and stream; $C$, Hourly temperature measurements of air at station 06075785, in stream at station 06075810, and in monitoring well SR0616 at depths of $1.72 \mathrm{ft}$ and $3.22 \mathrm{ft}$ below the streambed; and $D$, Diel temperature variation in monitoring well SR0616 at depths of $1.72 \mathrm{ft}$ and $3.22 \mathrm{ft}$ below the streambed, March 2007 through November 2007 and March 2008 through December 2008. 

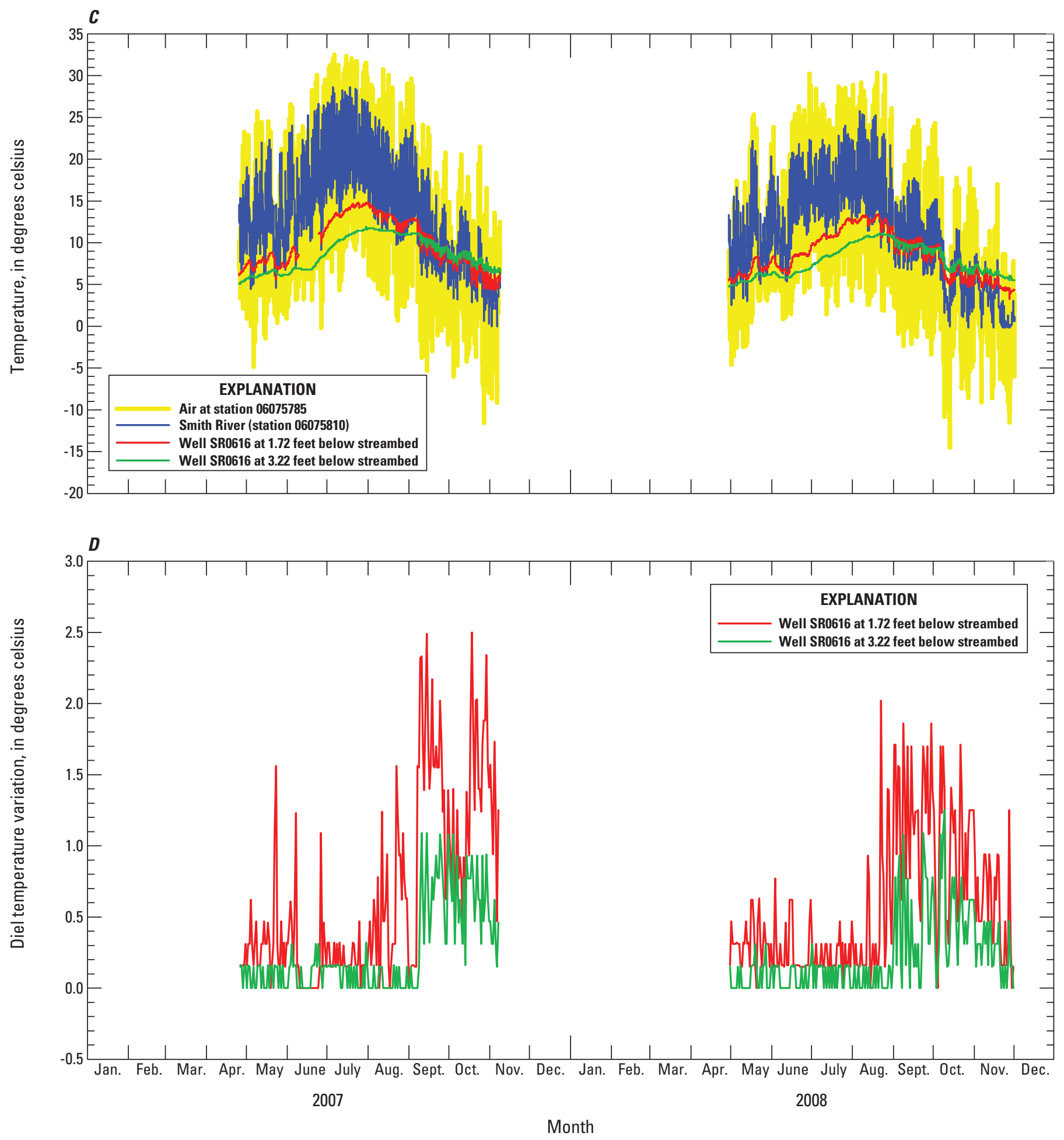

Figure 24. Data collected at the Smith River below North Fork Smith River monitoring site (station 06075810). A, Altitude of stream stage and groundwater at well SR0616; $B$, Difference in hydraulic head between groundwater at well SR0616 and stream; $C$, Hourly temperature measurements of air at station 06075785, in stream at station 06075810, and in monitoring well SR0616 at depths of $1.72 \mathrm{ft}$ and $3.22 \mathrm{ft}$ below the streambed; and D, Diel temperature variation in monitoring well SR0616 at depths of $1.72 \mathrm{ft}$ and $3.22 \mathrm{ft}$ below the streambed, March 2007 through November 2007 and March 2008 through December 2008. - Continued 


\section{Smith River above Mud Springs Creek (Groundwater and Surface-Water Monitoring Site 8)}

The effect of local flood irrigation on near-stream hydrology is apparent at the Smith River above Mud Springs Creek monitoring site (station 06075850, site 8 on fig. 8). Groundwater levels in all five wells (fig. 25) followed the general trend of the stream stage (Nilges and Caldwell, 2012), but was lower than stream stage (losing conditions) from March through late May of both 2007 and 2008. Starting in late May (most apparent in the 2008 hourly record of well SR0609, fig. 26A and $26 B$ ), groundwater levels rose abruptly and became higher than stream stage (gaining conditions). Specifically in well SR0609 (fig. 26A and 26B), gradients went from having groundwater levels approximately $0.1 \mathrm{ft}$ below the stream stage to a reversal of groundwater levels up to $0.55 \mathrm{ft}$ above stream stage within 5 days in May 2008. Groundwater levels declined to below stream stage (losing conditions) in late July to early August in both years. These periods of reversed gradients from losing to gaining conditions are coincident with periods of flood irrigation. Observations suggest flood irrigation contributed to increased local groundwater recharge, resulting in the rapid rise in groundwater levels and groundwater discharge to the stream.

The dynamic interaction of groundwater and surface water was observed in the temperatures at this site (Nilges and Caldwell, 2012). Temperatures measured below the streambed (example well SR0609 at 1.4 and $2.9 \mathrm{ft}$ below the streambed, fig. 26C) followed the general trend of the stream through late May of both 2007 and 2008 suggesting an infiltration of stream water to a depth of at least $2.9 \mathrm{ft}$ below the streambed. Starting in late May, temperatures below the streambed deviated from the stream and were distinctively cooler (fig. 26C) and relatively dampened (fig. 26D) coincident with the gradient shift from slightly losing to strongly gaining conditions (figs. 26A and 26B). Temperatures measured below the streambed again followed that of the stream in late July to early August in both years, indicative of a return to losing conditions supported by the water level data.

\section{Smith River below Newlan Creek (Groundwater and Surface-Water Monitoring Site 9)}

Interpretation of data collected at three wells just upstream from the Smith River gaging station below Newlan Creek (station 06076560; site 9 on fig. 8) ranged from somewhat inconclusive to an indication of strongly gaining conditions. Instream well SR06A consistently indicated gaining conditions with groundwater levels that ranged up to approximately $0.6 \mathrm{ft}$ above stream stage (Nilges and Caldwell, 2012). Indicative of gaining conditions, temperatures in the instream well SR06A at a depth of $2.05 \mathrm{ft}$ below the streambed and well SR0601 installed in the left bank generally followed the trend of the stream, but were typically cooler than the stream and showed little diel variation during the summer (Nilges and Caldwell, 2012). The other instream well (SR0602) had water levels very near that of the stream and were probably within measurement uncertainty. A poor seal may have existed around the casing of instream well SR0602 as water level and temperature data did not indicate strongly gaining conditions.

\section{Smith River above Rock Springs Creek (Groundwater and Surface-Water Monitoring Site 10)}

Variable hydrologic characteristics and effects of local flood irrigation and ditch operation are apparent at the Smith River above Rock Springs Creek monitoring site (station 06076580; site 10 on fig. 8). Groundwater levels in all five monitoring wells (fig. 27) followed the general trend of the stream stage (Nilges and Caldwell, 2012). However, conditions changed from gaining to losing several times during the record and interaction between groundwater and surface water appeared to vary between the left and right stream bank. Local flood irrigation on the right bank side of the stream at this location typically occurred two times per season (generally in the last half of June and then again in about early August). These irrigation periods are generally consistent with the period when groundwater levels rose above stream stage. Flood irrigation also occurs in places on the left side of the stream, but the timing was not reported.

Groundwater levels in well SR0605 (fig. 28A) (instream well near right bank) exhibited alternating gradients to and from the stream that were typically less than $0.2 \mathrm{ft}$ in either direction and at times within measurement uncertainty (fig. $28 B$ ). In comparison, water level data from well SR0606B (instream well near the left bank) exhibited gradients that sometimes differed in magnitude and direction from well SR0605 (fig. 28B). Most noticeably, measured gradients in well SR0606B were near neutral during 2008, whereas SR0605 had measured gradients of up to $0.20 \mathrm{ft}$ during the same time period.

Temperature data at well SR0605 supports variable gaining and losing conditions. Temperatures below the streambed were typically cooler than the stream (fig. 28C) and showed little diel variation from June through August (indicative of a gaining reach) (fig. 28D), but more closely followed the stream trend and exhibited diel variations at other times (fig. $28 D$ ). Temperature measured in the instream well near the left bank (SR0606B) followed the diel trend of the stream very closely (especially in 2008) throughout the record; the greater diel temperature variation and near-neutral hydraulic gradients (Nilges and Caldwell, 2012) indicates reduced or no groundwater flow to the stream at the left-bank side of the cross section. 


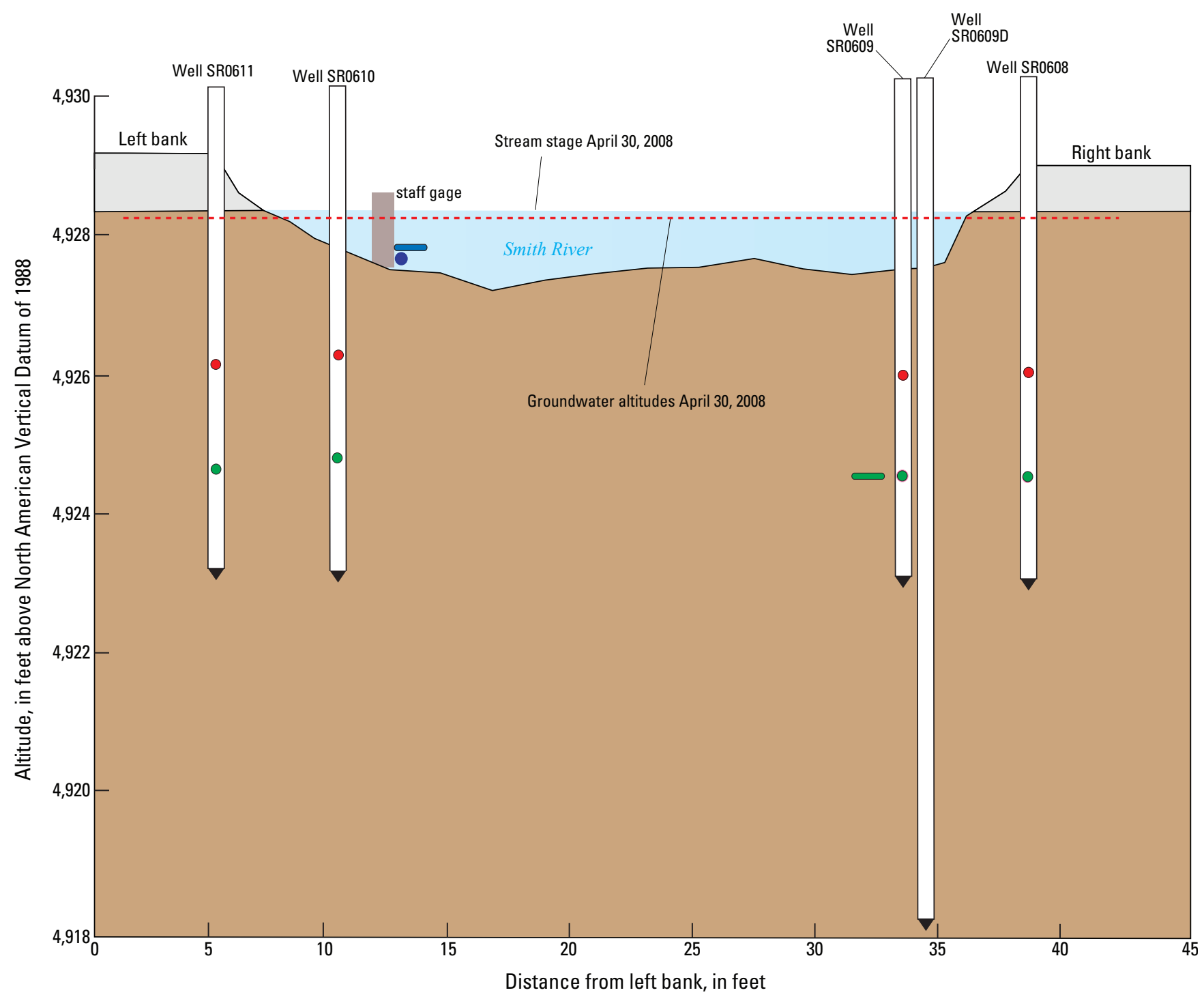

EXPLANATION

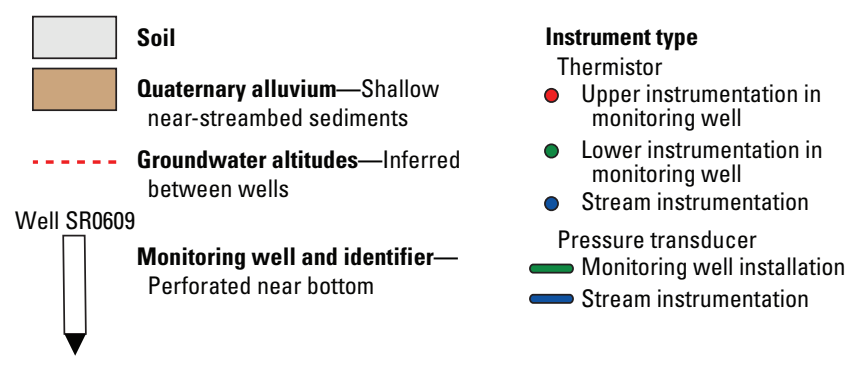

Figure 25. Channel geometry, monitoring well network, and thermistor and/or pressure transducer locations at Smith River above Mud Springs Creek monitoring site (station 06075850). Groundwater altitudes and stream stage for April 30, 2008. 

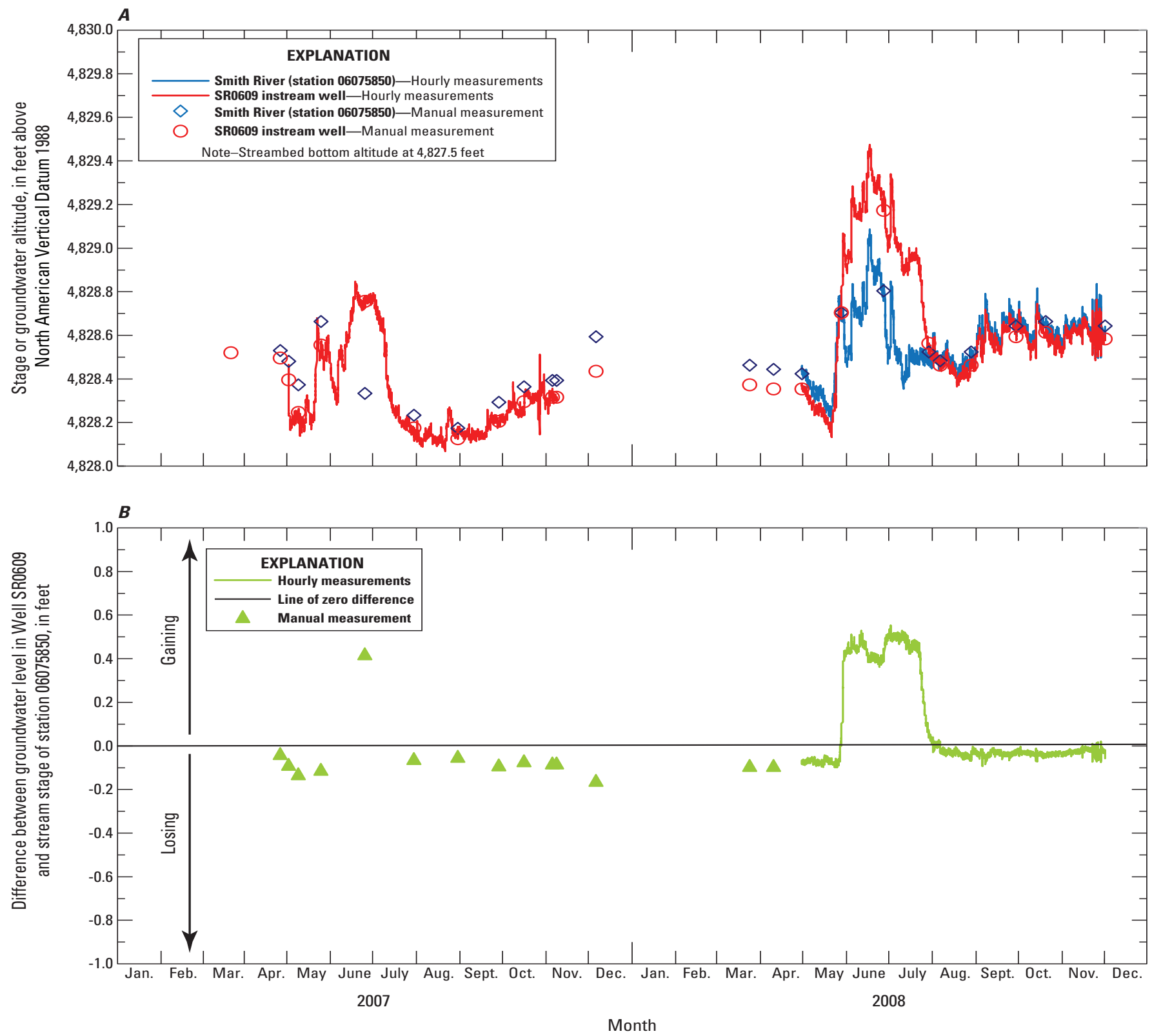

Figure 26. Data collected at the Smith River above Mud Springs Creek monitoring site (station 06075850). A, Altitude of stream stage and groundwater at well SR0609; $B$, Difference in hydraulic head between groundwater at well SR0609 and stream; $C$, Hourly temperature measurements of air at station 06075785, in stream at station 06075850, and in monitoring well SR0609 at depths of $1.4 \mathrm{ft}$ and $2.9 \mathrm{ft}$ below the streambed; and $D$, Diel temperature variation in monitoring well SR0609 at depths of $1.4 \mathrm{ft}$ and $2.9 \mathrm{ft}$ below the streambed, March 2007 through December 2007 and March 2008 through December 2008. 

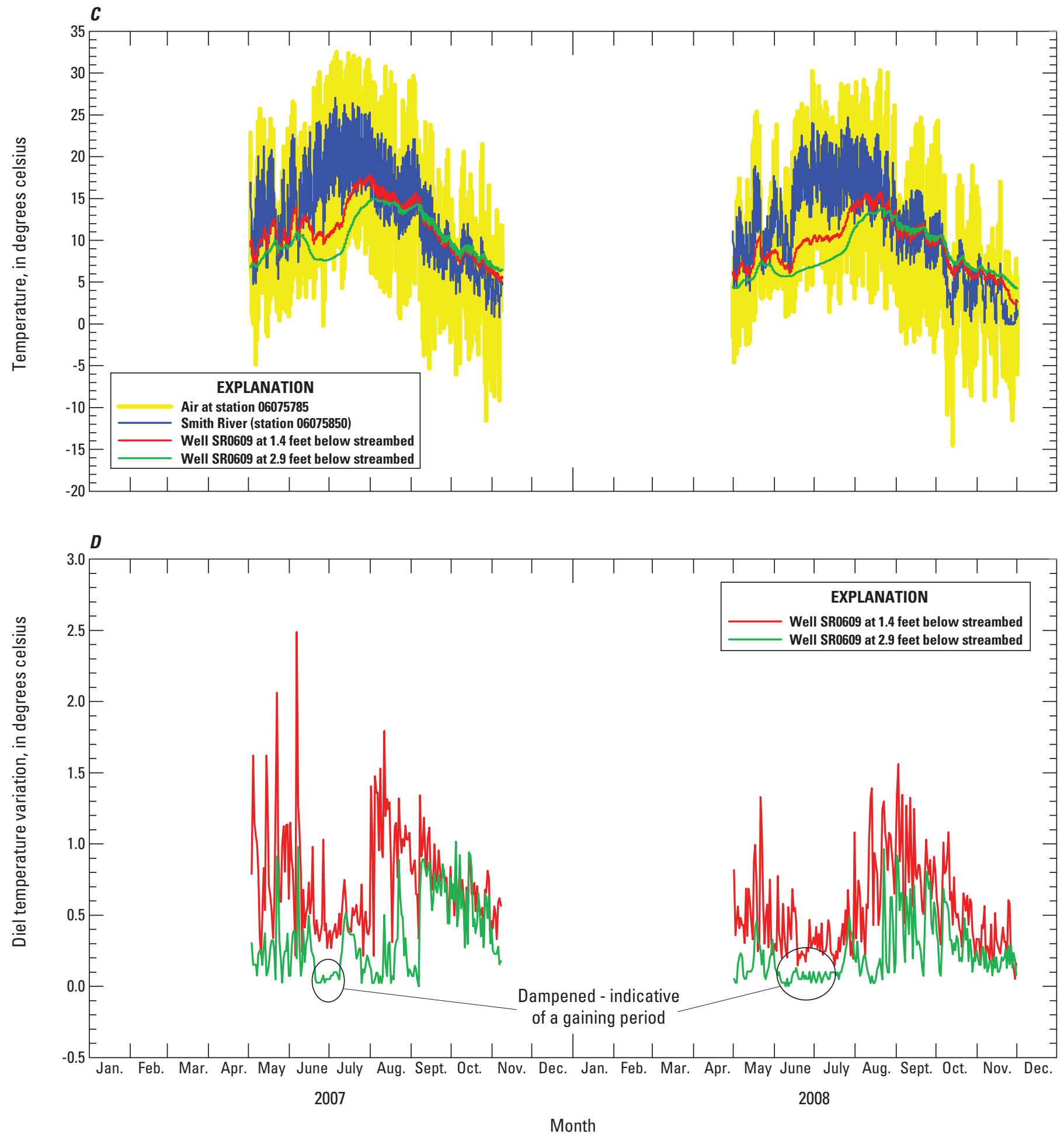

Figure 26. Data collected at the Smith River above Mud Springs Creek monitoring site (station 06075850). A, Altitude of stream stage and groundwater at well SR0609; $B$, Difference in hydraulic head between groundwater at well SR0609 and stream; $C$, Hourly temperature measurements of air at station 06075785, in stream at station 06075850, and in monitoring well SR0609 at depths of $1.4 \mathrm{ft}$ and $2.9 \mathrm{ft}$ below the streambed; and $D$, Diel temperature variation in monitoring well SR0609 at depths of $1.4 \mathrm{ft}$ and $2.9 \mathrm{ft}$ below the streambed, March 2007 through December 2007 and March 2008 through December 2008.—Continued 


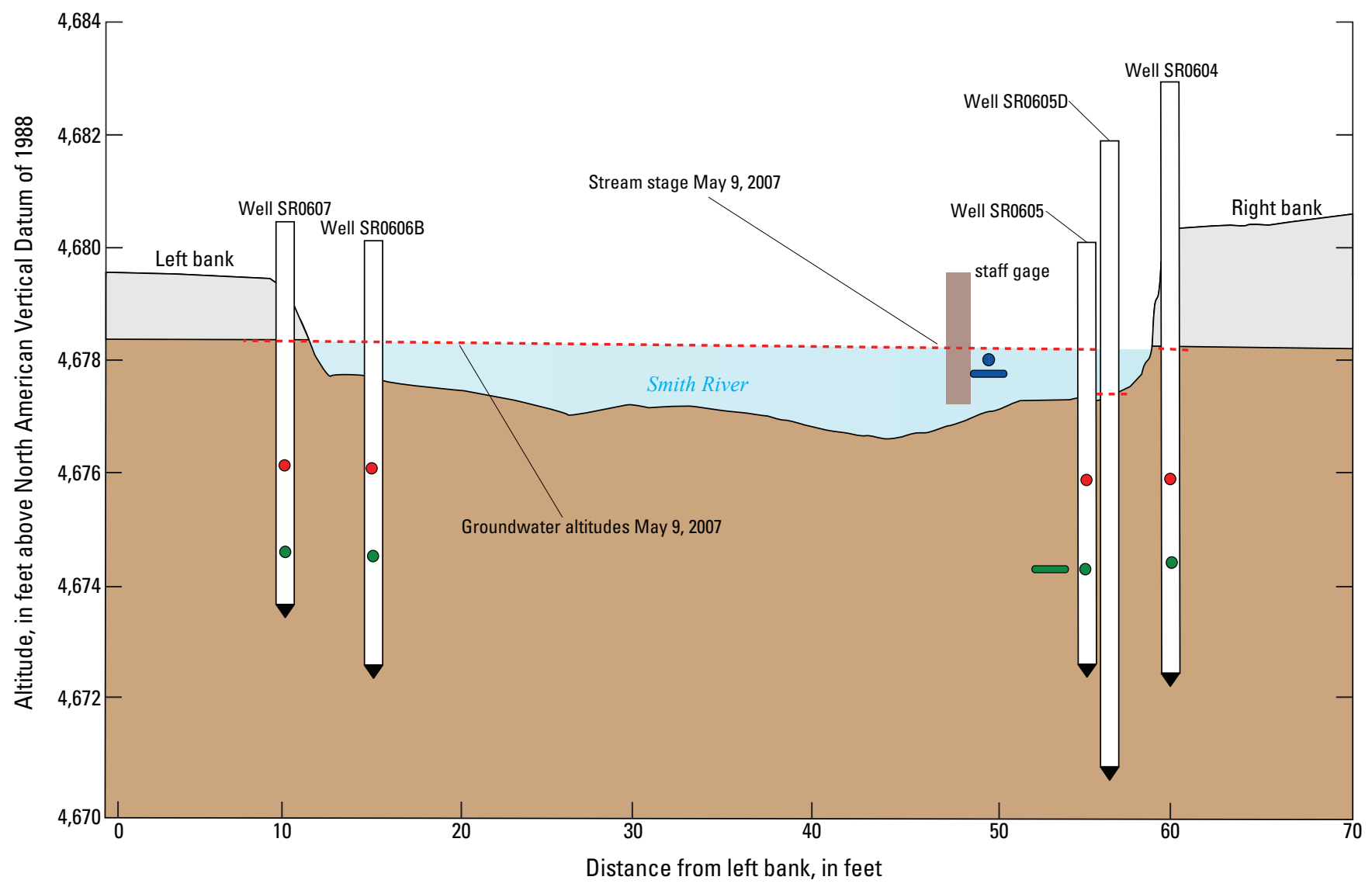

EXPLANATION

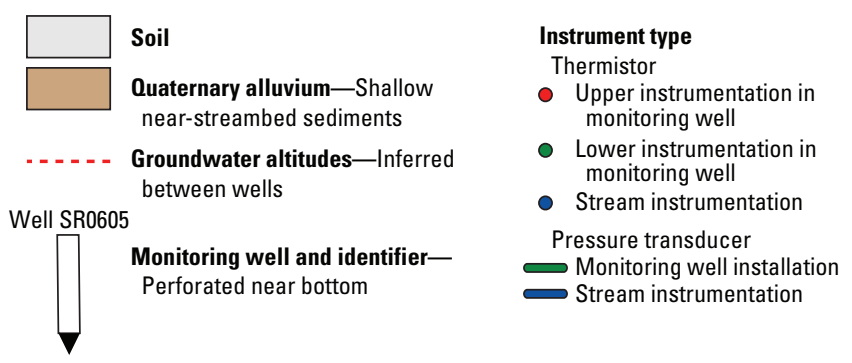

Figure 27. Channel geometry, monitoring well network, and thermistor and/or pressure transducer locations at Smith River above Rock Springs Creek monitoring site (station 06076580). Groundwater altitudes and stream stage for May 9, 2007. 

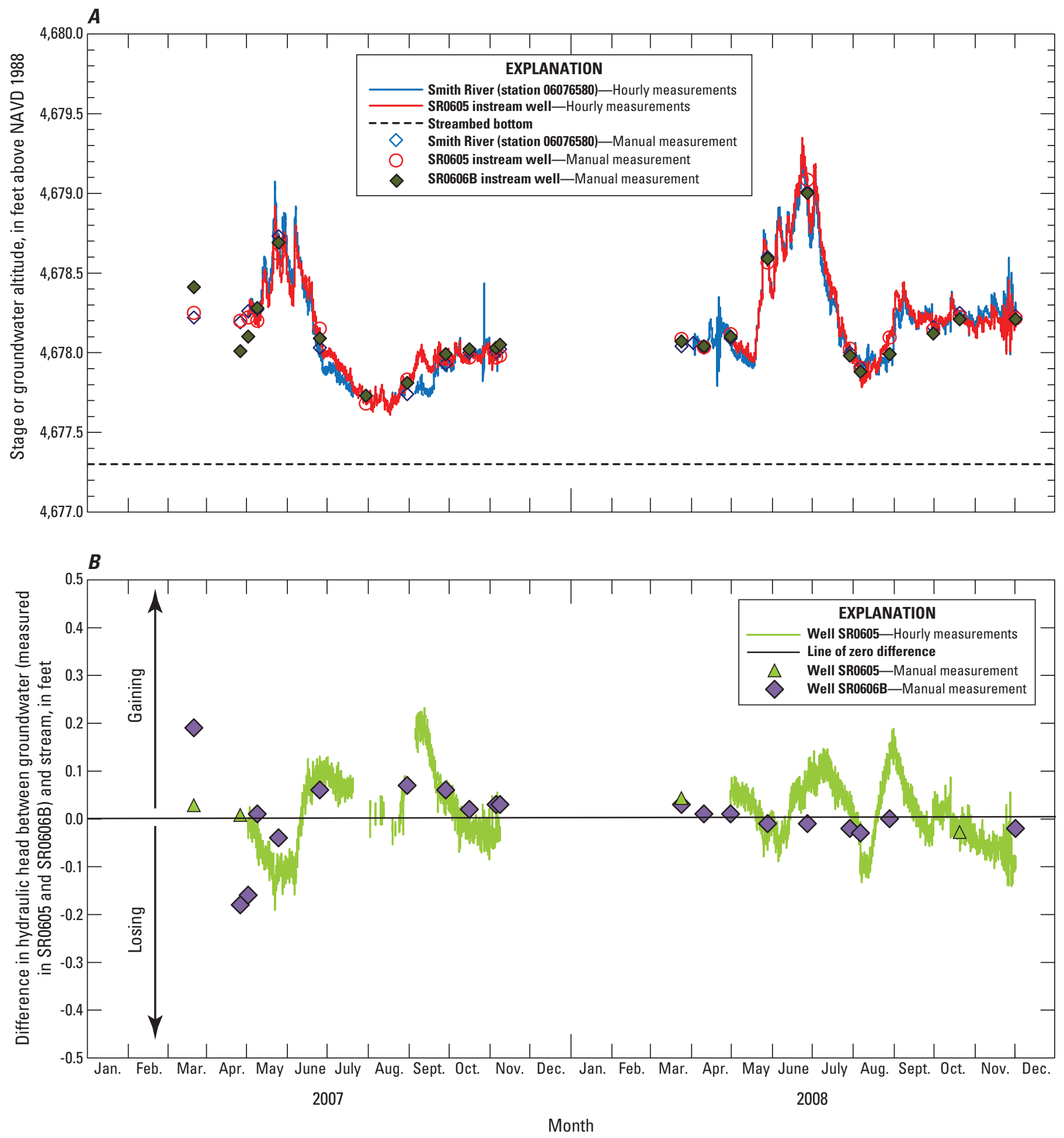

Figure 28. Data collected at the Smith River above Rock Springs Creek monitoring site (station 06076580). $A$, Altitude of stream stage and groundwater at well SR0605; B, Difference in hydraulic head between groundwater at wells SR0605 and SR0606B and stream; $C$, Hourly temperature measurements of air at station 06075785, in stream at station 06076580, and in monitoring well SR0605 at depths of $1.6 \mathrm{ft}$ and $3.1 \mathrm{ft}$ below the streambed; and $D$, Diel temperature variation in monitoring well SR0605 at depths of $1.6 \mathrm{ft}$ and $3.1 \mathrm{ft}$ below the streambed, March 2007 through November 2007 and March 2008 through December, 2008. 

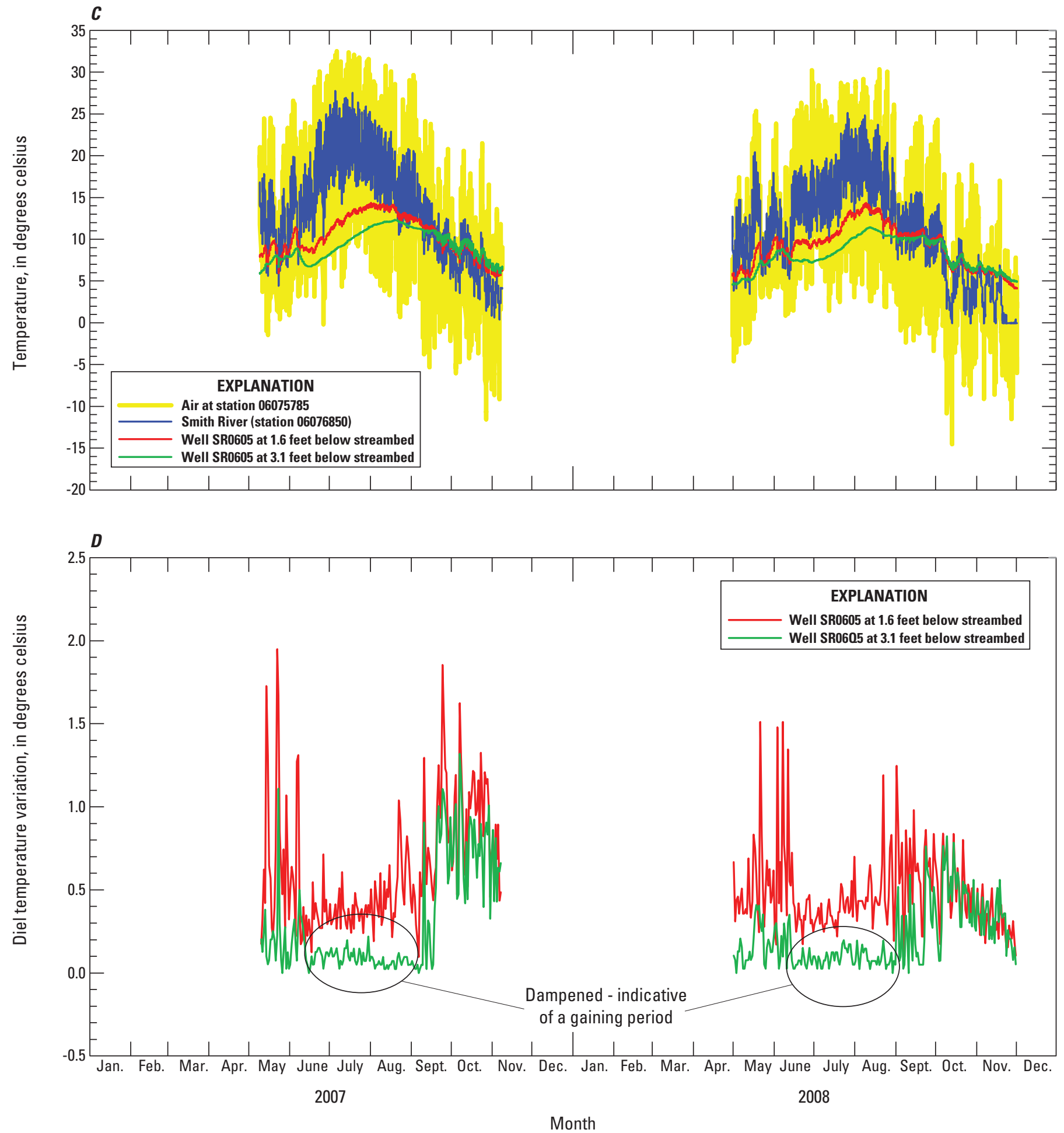

Figure 28. Data collected at the Smith River above Rock Springs Creek monitoring site (station 06076580). A, Altitude of stream stage and groundwater at well SR0605; $B$, Difference in hydraulic head between groundwater at wells SR0605 and SR0606B and stream; $C$, Hourly temperature measurements of air at station 06075785 , in stream at station 06076580 , and in monitoring well SR0605 at depths of $1.6 \mathrm{ft}$ and $3.1 \mathrm{ft}$ below the streambed; and $D$, Diel temperature variation in monitoring well SR0605 at depths of $1.6 \mathrm{ft}$ and $3.1 \mathrm{ft}$ below the streambed, March 2007 through November 2007 and March 2008 through December, 2008._Continued 


\section{Simulation of Water and Heat Transport}

Two-dimensional (2-D) fluid flow and energy (heat) transport VS2DH models (Healy, 2008; Healy and Ronan, 1996; Hsieh and others, 2000) were developed for three stream cross sections on the basis of field surveys of channel geometry, stream stage, groundwater level, and temperature data in an effort to constrain hydraulic properties of the Quaternary alluvium. Detailed descriptions of the selected cross-section models constructed for this study, including boundary conditions and results, are included in appendix 2.

Hydraulic properties selected for the final "best-fit" numerical models that most favorably matched observed conditions did show some variability among the cross sections and are summarized in table 9 . While several parameters were held constant among the models (hydraulic conductivity of soil, dispersivity, and heat capacity), the vertical and horizontal hydraulic conductivity of the Quaternary alluvium ranged from $3 \times 10^{-6}$ to $4 \times 10^{-5} \mathrm{ft} / \mathrm{s}$ and porosity ranged from 0.30 to 0.36 . Although several ratios of horizontal to vertical hydraulic conductivity were evaluated for each model, it appears that a 1 to 1 ratio adequately represented the modeled systems, and varying ratios did not appreciably improve simulated results (see appendix 4). Three-dimensional groundwater-flow models and further refinement of the subsurface hydraulic characteristics would strengthen the understanding of these modeled sections.

\section{Simulated Water Fluxes between Groundwater and Surface Water}

The flow of water (water flux) across the streambed, bottom, and side boundaries of the cross-section models was calculated using results of the calibrated 2-D water heat and solute transport VS2DH models (appendix 3). Water flux calculated for each boundary represents the amount of water that flowed across the entire length of each boundary over a unit (1-ft) width.

The monthly mean flux across the streambed boundary for each cross-section was calculated by averaging all daily flux values for each day of a given month (table 10). The cumulative monthly flux in cubic feet per month $\left(\mathrm{ft}^{3} / \mathrm{month}\right)$ was calculated by summing each daily flux value in a given month across the entire streambed cross section. Positive flux values indicate groundwater flow to the stream, whereas negative flux values indicate flow from the stream to groundwater. When compared to seepage run data collected as part of the study (see discussion below), the numerical models showed reasonable approximations of the streambed and shallow aquifer environment near the stream cross sections, and dynamic changes in flux between the stream and the groundwater through different model boundaries.

Net gains calculated from the synoptic streamflow data at the South Fork Smith River near mouth (station 06075785) during periods of limited diversions (tables 5 through 7) ranged from 2.97 to $5.17 \mathrm{ft}^{3} / \mathrm{s}\left(0.34\right.$ to $0.59 \mathrm{ft}^{3} / \mathrm{s}$ per river mile) over the 8.7-mi length of the South Fork of the Smith River (river mile 11.8 to 3.1 ) that ends at the modeled cross section. Simulated flux values of 2.0 to 3.4 cubic feet per day $\left(\mathrm{ft}^{3} / \mathrm{d}\right)$ can be extrapolated to net gains of 0.12 to $0.21 \mathrm{ft}^{3} / \mathrm{s}$ per river mile, assuming uniform stream width. Although water fluxes calculated at the modeled cross section were less than the average flux calculated from the synoptic measurements, estimates from these two methods are in general agreement, especially when taking into account that varying hydraulic characteristics, head gradients, and stream width are likely.

The simulated water flux at the North Fork Smith River near mouth (station 06075700; table 10) matched the direction of flow (losing) but failed to closely match fluxes calculated from the synoptic streamflow events (tables 5 through 7) during periods of limited diversion. Net losses calculated from synoptic streamflow data ranged from 2.40 to $7.97 \mathrm{ft}^{3} / \mathrm{s}(0.89$ to $2.95 \mathrm{ft}^{3} / \mathrm{s}$ per river mile) over the 2.7 -mi length of the North Fork of the Smith River (Highway 360 bridge to near mouth) that ends at the modeled cross section. Simulated flux values ranging from near 0 to about $1.7 \mathrm{ft}^{3} / \mathrm{d}$ (appendix 3, fig. 3-2) can be extrapolated to net losses of from near 0 to about 0.10 $\mathrm{ft}^{3} / \mathrm{s}$ per river mile, assuming a uniform stream width. This difference suggests that losses are not uniform and that point scale measurements can vary greatly along the reach attributed to varying hydraulic characteristics and head gradients.

A direct comparison of the simulated water flux with the synoptic streamflow events (tables 5 through 7) during periods of limited irrigation diversion was not possible at the Smith River above Mud Springs Creek cross section (station 06075850; table 10) since modeled dates were not coincident with the synoptic streamflow measurements. Synoptic streamflow measurements indicated minimal net gains or gains that were less than measurement errors along the stream reach that ended at this cross section. Qualitatively, this differs from the simulated water flux during the spring and fall of 2008 and the corresponding temperature and head data, which indicated slightly losing conditions at this location. This difference suggests that water exchange direction and rate are not uniform along this reach of the Smith River.

\section{Discussion}

Groundwater and surface-water interactions between the Smith River, its tributaries, and the underlying aquifers exist throughout the entire Smith River watershed varying considerably with season and location. Collectively, data show the following: (1) the hydraulic connectedness of groundwater and surface water, (2) the presence of both losing and gaining stream reaches, (3) dynamic changes in direction and magnitude of water flow between the stream and groundwater with time, (4) the effects of flow alteration and irrigation on groundwater levels and gradients in the watershed, and (5) evidence and timing of irrigation return flows to area streams. 
Table 9. Summary of hydraulic parameters used in final calibrated VS2DH simulations of selected modeled cross sections in the upper Smith River watershed, Montana

$\left[\mathrm{ft} / \mathrm{s}\right.$, feet per second; $\mathrm{ft}$, feet; ${ }^{\circ} \mathrm{C}$, degrees Celsius; $\mathrm{W} / \mathrm{ft}{ }^{\circ} \mathrm{C}$, Watts per foot degrees Celsius; $\mathrm{J} / \mathrm{ft}^{3}{ }^{\circ} \mathrm{C}$, Joules per cubic foot degrees Celsius]

\begin{tabular}{lccc}
\hline \multicolumn{1}{c}{ Hydraulic parameter } & $\begin{array}{c}\text { South Fork Smith } \\
\text { River near mouth } \\
\text { (station 06075785) }\end{array}$ & $\begin{array}{c}\text { North Fork Smith } \\
\text { River near mouth } \\
\text { (station 06075700) }\end{array}$ & $\begin{array}{c}\text { Smith River above } \\
\text { Mud Springs Creek } \\
\text { (station 06075850) }\end{array}$ \\
\hline Porosity & 0.36 & ${ }^{1} 0.3$ & ${ }^{1} 0.3$ \\
$\begin{array}{l}\text { Hydraulic conductivity of near-streambed sedi- } \\
\text { ments, horizontal direction (ft/s) }\end{array}$ & $3 \times 10^{-6}$ & $3 \times 10^{-6}$ & $4 \times 10^{-5}$ \\
$\begin{array}{l}\text { Hydraulic conductivity of near-streambed sedi- } \\
\text { ments, vertical direction (ft/s) }\end{array}$ & $3 \times 10^{-6}$ & $3 \times 10^{-6}$ & $4 \times 10^{-5}$ \\
$\begin{array}{l}\text { Hydraulic conductivity of soil, horizontal and } \\
\text { vertical directions (ft/s) }\end{array}$ & $3 \times 10^{-10}$ & $3 \times 10^{-10}$ & $3 \times 10^{-10}$ \\
$\begin{array}{l}\text { Dispersivity (ft) } \\
\text { Heat capacity of saturated sediments }\left(\mathrm{W} / \mathrm{ft}{ }^{\circ} \mathrm{C}\right)\end{array}$ & ${ }^{2} 0.03$ & ${ }^{2} 0.03$ & 20.03 \\
Heat capacity of water at $20^{\circ} \mathrm{C}\left(\mathrm{J} / \mathrm{ft}^{3}{ }^{\circ} \mathrm{C}\right)$ & 20.6 & ${ }^{2} 0.6$ & ${ }^{2} 0.6$ \\
\hline
\end{tabular}

${ }^{1}$ Based on Freeze and Cherry, 1979.

${ }^{2}$ Based on Niswonger and Prudic, 2003.

Table 10. Summary of estimated water flow across streambed boundaries of the South Fork Smith River, North Fork Smith River, and Smith River modeled cross sections.

[Abbreviations: $\mathrm{ft}^{3} / \mathrm{d}$, cubic feet per day; $\mathrm{ft}^{3} /$ month, cubic feet per month; NM, not modeled; negative numbers indicate flow is from surface water to groundwater, positve numbers indicate flow is from groundwater to surface water. Note: flow values represent flow across a unit width (1-foot wide) of the modeled streambed]

\begin{tabular}{|c|c|c|c|c|c|c|}
\hline \multirow[b]{2}{*}{ Month } & \multicolumn{3}{|c|}{ Monthly mean flow (ft $3 / \mathrm{d})$} & \multicolumn{3}{|c|}{ Cumulative monthly flow (ft $\left.\mathrm{ft}^{3} / \mathrm{month}\right)$} \\
\hline & $\begin{array}{c}\text { South Fork } \\
\text { Smith River } \\
\text { near mouth } \\
\text { (station } \\
\text { 06075785) }\end{array}$ & $\begin{array}{l}\text { North Fork } \\
\text { Smith River near } \\
\text { mouth (station } \\
06075700 \text { ) }\end{array}$ & $\begin{array}{c}\text { Smith River above } \\
\text { Mud Springs } \\
\text { Creek (station } \\
06075850 \text { ) }\end{array}$ & $\begin{array}{c}\text { South Fork } \\
\text { Smith River } \\
\text { near mouth } \\
\text { (station } \\
\text { 06075785) }\end{array}$ & $\begin{array}{c}\text { North Fork } \\
\text { Smith River near } \\
\text { mouth (station } \\
06075700 \text { ) }\end{array}$ & $\begin{array}{c}\text { Smith River above } \\
\text { Mud Springs } \\
\text { Creek (station } \\
06075850 \text { ) }\end{array}$ \\
\hline \multicolumn{7}{|c|}{2007} \\
\hline May & 2.77 & -0.42 & NM & 85.95 & -13.32 & NM \\
\hline June & 2.74 & -0.90 & NM & 82.19 & -27.14 & NM \\
\hline July & 2.30 & -1.37 & NM & 71.15 & -42.52 & NM \\
\hline August & 2.25 & -1.51 & NM & 69.66 & -46.87 & NM \\
\hline September & 2.66 & -1.10 & NM & 79.71 & -33.11 & NM \\
\hline October & 2.54 & -0.51 & NM & 78.74 & -15.75 & NM \\
\hline November & $\mathrm{NM}$ & NM & NM & NM & NM & NM \\
\hline \multicolumn{7}{|c|}{2008} \\
\hline May & 2.82 & -0.62 & -1.23 & 87.54 & -19.29 & -38.20 \\
\hline June & 3.19 & -0.22 & 7.41 & 95.68 & -6.64 & 222.36 \\
\hline July & 2.66 & -0.61 & 7.48 & 82.35 & -18.83 & 232.01 \\
\hline August & 2.49 & -0.82 & -0.48 & 77.23 & -25.50 & -14.93 \\
\hline September & 3.03 & -0.10 & -0.60 & 91.00 & -2.93 & -17.97 \\
\hline October & 2.44 & ${ }^{1}-0.06$ & -0.54 & 75.59 & ${ }^{1}-1.82$ & -16.87 \\
\hline November & 2.23 & NM & -0.41 & 66.84 & NM & -12.24 \\
\hline
\end{tabular}

${ }^{1}$ Based on 29 days. 
The effect of groundwater and surface-water interactions is most apparent along the North and South Forks of the Smith River where the magnitude of streamflow losses and gains can be greater than the magnitude of flow within the stream. Groundwater and surface-water interactions occur downstream from the confluence of the North and South Forks, but are less discernible compared to the overall magnitude of the mainstem streamflow.

The North Fork Smith River begins in the Little Belt Mountains to the northwest of White Sulphur Springs and flows for nearly $40 \mathrm{mi}$ to the southwest as it gains flow from tributaries originating in both the Little Belt and the Castle Mountains before joining the South Fork Smith River. Streamflow in this reach is highly managed at times through regulation at Lake Sutherlin (North Fork Smith River Reservoir) in the upper North Fork Smith River drainage and by diversions that supply water for both flood irrigation and sprinkler irrigation. During non-irrigation periods, North Fork Smith River streamflow measured below Spring Creek (about 8.4 miles upstream from the confluence with the South Fork Smith River) ranged from $12.4 \mathrm{ft}^{3} / \mathrm{s}$ to $16.4 \mathrm{ft}^{3} / \mathrm{s}$. Leakage to groundwater and diversions along the 5.8-mile downstream reach ranged from $2.23 \mathrm{ft}^{3} / \mathrm{s}$ to $8.49 \mathrm{ft}^{3} / \mathrm{s}$ during the non-irrigation season. Releases from Lake Sutherlin increased during periods of irrigation. North Fork Smith River streamflow below Spring Creek was $72.5 \mathrm{ft}^{3} / \mathrm{s}$ measured during a seepage run in August 2007. Diversions and leakage to groundwater along the 5.8mile downstream reach measured during this time accounted for about $67.6 \mathrm{ft}^{3} / \mathrm{s}$ of streamflow losses.

The South Fork Smith River begins in the Castle Mountains and flows to the west and northwest for about $38 \mathrm{mi}$. The South Fork Smith River gains flow from tributaries originating from both the Castle and Big Belt Mountains and from an unsealed artesian well near its headwaters. Unlike the North Fork Smith River, the South Fork Smith River has limited reservoir capacity. Streamflow near the mouth was typically less than $10 \mathrm{ft}^{3} / \mathrm{s}$ for most of the year after the spring snowmelt. The lower 15-mile reach of the South Fork Smith River showed an overall net gain during the entire study, with measured gains in streamflow ranging from $0.13 \mathrm{ft}^{3} / \mathrm{s}$ to 9.33 $\mathrm{ft}^{3} / \mathrm{s}$. However, individual sections of the South Fork Smith River varied from gaining to losing. Streamflow approached or achieved no-flow conditions along a section of the South Fork Smith River near river mile 11.8 during the summer irrigation seasons as a result of streamflow losses to irrigation withdrawals, evapotranspiration, and infiltration. Flow returned downstream primarily due to groundwater discharge (gaining conditions) to the river.

Groundwater discharge occurred along the uppermost reach of the Smith River and the lower extents of the North Fork Smith River and South Fork Smith River throughout the study. Conditions ranged from losing to gaining below river mile 122.2 (122.2 miles upstream from the Smith River confluence with the Missouri River) until river mile 80.8 at the Smith River below Eagle Creek streamflow-gaging station (station number 06077200); however, these gains and losses were minor (less than about 15 percent) compared to tributary inflow and main-stem streamflow. The average annual streamflow measured at Smith River below Eagle Creek streamflowgaging station (station number 06077200) was $244 \mathrm{ft}^{3} / \mathrm{s}$ (2005-2010). About 33 percent (81 of $244 \mathrm{ft}^{3} / \mathrm{s}$ ) of the Smith River streamflow measured below Eagle Creek can be attributed to contributions from the drainage area upstream from the Smith River below Newlan Creek streamflow-gaging station at river mile 112.1 which includes inflow from North and South Forks of the Smith River, Birch Creek, and Newlan Creek. The drainage area between the Smith River below Newlan Creek (station 16076560) and Smith River below Eagle Creek (station 06077200) streamflow gaging stations contributed about 67 percent $\left(143 \mathrm{ft}^{3} / \mathrm{s}\right)$ of the total streamflow observed at the Smith River below Eagle Creek. Sheep Creek accounts for much of the $143 \mathrm{ft}^{3} / \mathrm{s}$ streamflow increase in the Smith River between river miles 112.1 and 80.8 .

At about river mile 80.8 (below the mouth of Eagle Creek), the Smith River flows through steep-sided canyons for nearly $60 \mathrm{mi}$. This reach is characterized by its natural setting and minimal disturbance from human development. Streamflow in this reach is supported by the main-stem inflow entering the canyon and the natural tributary inflow. The mainstem inflow is dependent upon upstream management whereas tributary inflow is predominantly unmanaged. There are minimal retention reservoirs or diversions within this part of the system. As the least managed reach, variability in streamflow within this reach is primarily dependent upon climate and weather conditions.

Data from the streamflow-gaging stations above (Smith River below Eagle Creek - station 06077200, continuous operation) and below (Smith River near Eden -station 06077500, seasonal operation) the 60-mi long canyon reach indicate a median streamflow increase of $58 \mathrm{ft}^{3} / \mathrm{s}$ (23 percent) when both streamflow-gaging stations were in operation between March, 2006 and October, 2010. Although there are several tributaries along this 53.8-mi reach of the Smith River, there were periods when streamflow remained nearly identical or even decreased between the upstream and downstream stations. Travel times affect these observations, but streamflow is affected by gains and losses along this section of the Smith River as it travels through the steep-sided limestone canyon. While there were losses from the stream to the underlying aquifers, perennial conditions were observed along the entire reach.

Short time spans occurred between the application of diverted water for flood irrigation and the resulting effects to the local hydrologic flow system. Wide-spread flood irrigation occurred in May through June, and sometimes occurred again in the late-summer to early-fall. Irrigation and conveyance water that is not evaporated or consumed by plants can return to the stream as groundwater return flows or through drainage ditches downstream from where the water was diverted. Hydraulic gradients increased or reversed direction (changed from losing to gaining) at several monitoring sites coincident with the timing of nearby flood irrigation. Some of these hydraulic gradient shifts occurred within days of 
applied irrigation with the timing dependent upon the distance between the irrigated fields and the observation wells and stream gages.

The time it takes for the actual applied water to reach the stream is dependent upon the length of the groundwater flow path, hydraulic gradients, and aquifer characteristics. In reality, the actual travel time for the applied water to reach the stream could be several days or even months. For example, the continuous streamflow record of several tributaries and the main stem Smith River at the streamflow-gaging station below Newlan Creek (06076560) during the 2010 irrigation illustrated the timing and magnitude of net irrigation return flows in the area. Tributary inflow upstream from the Smith River streamflow-gaging station below Newlan Creek nearly matched outflow at this gage during the last two weeks of May 2010, coincident with the timing of high diversion rates and extensive flood irrigation. This was followed by a month-long period (early June 2010 through early July 2010) with the largest net increase in streamflow at the Smith River streamflow-gaging station below Newlan Creek relative to tributary inflow. This observation is the result of groundwater discharge to the Smith River due to irrigation return flow. The remaining continuous record (April through September 2010) shows a nearly stable net increase of flows of about $25 \mathrm{ft}^{3} / \mathrm{s}$.

\section{Summary}

The Smith River watershed encompasses approximately 2,000 $\mathrm{mi}^{2}$ of the upper Missouri River Basin in Meagher and Cascade Counties of west-central Montana. The 125-milong Smith River, a tributary of the Missouri River, is highly valued as an important agricultural resource and for its many recreational uses. Nearly 35,000 acres of the Smith River watershed are irrigated, primarily using water directly withdrawn from the Smith River and its tributaries. During a recent drought starting in about 1999, streamflow was not sufficient to meet all of the irrigation demands much less maintaining instream flow requirements to support viable fish habitat and recreational activities. In 2006, the U.S. Geological Survey (USGS), in cooperation with the Meagher County Conservation District (MCCD), initiated a multi-year hydrologic investigation of the Smith River watershed designed to expand the knowledge of the hydrologic system through a systematic program of data compilation and collection, research, and analysis. Although study efforts included the entire watershed, the majority of data-collection efforts took place in an approximately 1,200 $\mathrm{mi}^{2}$ focus area in the upper Smith River watershed.

The objective of this component of the Smith River watershed hydrologic investigation was to provide an increased understanding of the water resources of the Smith River watershed, including a detailed description of groundwater and surface-water interactions. Specifically, the description would include the delineation of gaining and losing reaches of the Smith River and selected tributaries, quantification of gains and losses during different hydrologic conditions, and the relation between groundwater levels and stream stage.

The most productive and developed aquifers in the Smith River watershed are the alluvium and Tertiary basin-fill sediments of the valley lowlands and tributary drainages. The alluvial aquifers are generally composed of sand and gravel with varying clay layers. The basin-fill aquifers are generally fine grained with lower permeability. However, some of the most productive wells produce water from the basin-fill sediments. Wells within older sedimentary and igneous rocks in the area are typically of low yield and are utilized for domestic and stock purposes. Potentiometric surface maps were generated from water-level measurements of area wells and stream stage during March 2007, August 2007, October 2007, and April 2008. Groundwater-flow direction generally followed landsurface topography from the uplands to the axis of alluvial valleys of the Smith River and its tributaries. Flow to and from the surface water was apparent, especially at the lower ends of the North Fork Smith River and the South Fork Smith River, as well as at the upper reach of the main stem of the Smith River. Groundwater gradients ranged from approximately 10 $\mathrm{ft} / \mathrm{mi}$ to $50 \mathrm{ft} / \mathrm{mi}$ in the upper Smith River valley.

Daily streamflow at all four long-term USGS streamflowgaging stations on the Smith River showed similar trends, with high flows typically occurring in the spring to early summer and more stable, moderate to low flows occurring from midsummer through early spring. Streamflow typically increased in downstream order - primarily due to tributary and net groundwater inflow. A review of continuous daily streamflow records for water years 2005 through 2010 indicated a mean annual increase of $163 \mathrm{ft}^{3} / \mathrm{s}$ between the uppermost streamflow-gaging station below Newlan Creek (river mile 112.1, station 06076560) and the streamflow-gaging station below Eagle Creek (river mile 80.8, station 06077200). The upper $517 \mathrm{mi}^{2}$ of the watershed, represented by the USGS streamflow-gaging station at the Smith River below Newlan Creek, contributed about 33 percent of the total flow observed at the Smith River below Eagle Creek streamflow-gaging station.

Three separate single-day, synoptic streamflow measurements (seepage runs) were conducted during periods of limited irrigation diversion (March 22, 2007; October 16, 2007; and April 10, 2008) at up to 45 main stem and tributary sites within the upper Smith River watershed. The exchange of groundwater and surface water was quantitatively estimated by examining the net differences between measured sections of the main stem and accounting for tributary inflow and diversions. Net gains ranging from 2.44 to $9.33 \mathrm{ft}^{3} / \mathrm{s}$ were measured over the lower $14.9 \mathrm{mi}$ of the South Fork Smith River. The North Fork Smith River had net losses ranging from 2.23 to $8.49 \mathrm{ft}^{3} / \mathrm{s}$ over the lower 8.1 -mi reach. Overall, net gains (flow from the groundwater to the surface water) were observed over the upper 41.4 river miles of the Smith River that ranged from 13.0 to $28.9 \mathrm{ft}^{3} / \mathrm{s}$. 
Groundwater levels at 10 groundwater/surface-water monitoring sites were typically the highest in the late spring to early summer (late May through early July), fell during the summer (July to early August), and then recovered during the late summer through the fall of both 2007 and 2008. High groundwater levels in the near-stream wells in the late spring or early summer were affected by increased recharge from snowmelt, local precipitation, high stream flows, and local flood irrigation at some locations. Summer declines in groundwater levels can be associated with reduced recharge from less precipitation and local flood irrigation, local and regional effects of groundwater withdrawals, increased ET, and reduced streamflow and subsequent leakage in some area streams. Groundwater levels rebounded during mid-August to mid-September at most sites as a result of decreases in groundwater use (irrigation), increased flow in losing streams, decreased ET, and the onset of local flood irrigation at some sites. Head gradients at six of the monitored sites reversed direction at times during the course of the study. Many sites showed gradients from one stream bank to the other.

The groundwater/surface-water monitoring network sites exhibited variable gaining and losing conditions during the study. Two sites along the South Fork Smith River ranged from gaining at times to losing as groundwater levels declined during the summer months. Groundwater levels rebounded in the late summer to early fall. Groundwater levels fell below the streambed during the summer months at one South Fork Smith River site and the stream became dry for a short period in 2008. Near its mouth, the South Fork Smith River demonstrated strongly gaining conditions, with head gradients toward the stream and stream temperature dampened by the inflow of cooler groundwater during the summer. A site on the lower North Fork Smith River demonstrated losing conditions over most of the record, with groundwater levels well below stream stage and groundwater temperatures that closely matched those of the stream (indicative of advective flow of heat from the stream to the groundwater).

Hydrologic responses to local groundwater recharge from local flood irrigation occurred at several groundwater/ surface-water monitoring network sites. Groundwater levels increased at these sites coincident with the timing of local flood irrigation. Also coincident with observed local flood irrigation, water temperatures measured in the monitoring wells at depth below the streams went from closely following stream temperatures to diverging from the surface-water trend as groundwater discharge increased to the stream. Gradients at one Smith River cross section went from having groundwater levels approximately $0.1 \mathrm{ft}$ below the stream stage to a reversal of groundwater levels up to $0.6 \mathrm{ft}$ above stream stage within 5 days.

Two-dimensional heat and solute transport VS2DH models constructed for selected stream cross sections focused on sites with observed distinctions between temperature and head data in an effort to constrain hydraulic properties of the Quaternary alluvium. Hydraulic conductivity of the Quaternary alluvium of the modeled sections ranged from $3 \times 10^{-6}$ to
$4 \times 10^{-5} \mathrm{ft} / \mathrm{s}$. The models showed reasonable approximations of the streambed and shallow aquifer environment near the stream cross sections. Three-dimensional groundwater-flow models and further refinement of the subsurface hydraulic characteristics would strengthen the understanding of these modeled sections.

The use of multiple methods of investigation increased the understanding of the flow system and the interaction of groundwater and surface water within the upper Smith River watershed. Results from this study have shown the following: (1) groundwater and surface are hydraulically connected along the Smith River and its tributaries; (2) both losing and gaining stream reaches occur throughout the area; (3) dynamic changes in the direction and magnitude of water flow between the stream and groundwater with time; (4) local flood irrigation effects groundwater levels and gradients; and (5) local flood irrigation results in irrigation return flows to area streams.

\section{References Cited}

Bureau of Reclamation, 2007, AgriMet Weather Data-Great Plains cooperative agricultural weather network: Bureau of Reclamation, accessed February 8, 2013, at http://www.usbr. gov/gp/agrimet/station_wssm_whitesulphur.cfm.

Bureau of Reclamation, 2008, AgriMet Weather Data—Great Plains cooperative agricultural weather network: Bureau of Reclamation, accessed February 8, 2013, at http://www.usbr. gov/gp/agrimet/station_wssm_whitesulphur.cfm.

Cannon, M.R., and Johnson, D.R., 2004, Estimated water use in Montana in 2000: U.S. Geological Survey Scientific Investigations Report 2004-5223, 50 p.

Constantz, Jim, 2008, Heat as a tracer to determine stream water exchanges: Water Resources Research, v. 44, W00D10, doi:10.1029/2008WR006996, 20 p.

Constantz, J., and Stonestrom, D.A., 2003, Heat as a tracer of water movement near streams, p. 1-6, in Stonestrom, D.A., and Constantz, J., eds, Heat as a tool for studying the movement of ground water near streams: U.S. Geological Survey Circular 1260, $96 \mathrm{p}$.

Eddy-Miller, C.A., Wheeler, J.D., and Essaid, H. I., 2009, Characterization of interactions between surface water and near-stream groundwater along Fish Creek, Teton County, Wyoming, by using heat as a tracer: U.S. Geological Survey Scientific Investigations Report 2009-5160, 53 p.

Essaid, H.I., Zamora, C.M., McCarthy, K.A., Vogel, J.R., and Wilson, J.T., 2008, Using heat to characterize streambed water flux variability in four stream reaches: Journal of Environmental Quality, v 37, p. 1010-1023. 
Farnes, Phil, 2007, 1971-2000 Average Annual Precipitation, Meagher County, Montana: Montana State Library Natural Resource Information System, Map Request 07NRCS0020, map scale 1:250,000, 1 sheet.

Fenneman, N.M., and Johnson, D.W., 1946, Physical divisions of the United States: U.S. Geological Survey, scale $1: 7,000,000,1$ sheet.

Freeze, R.A., and Cherry, J.A., 1979, Groundwater: Englewood, N.J., Prentice Hall, Inc., 604 p.

Groff, S.L., 1965, Reconnaissance groundwater and geological studies, western Meagher County, Montana: Montana Bureau of Mines and Geology, Special Publication 35, Ground-Water Report 3, 23 p.

Healy, R.W., 2008, Simulating water, solute, and heat transport in the subsurface with the VS2DI Software Package: Vadose Zone Journal, v. 7, no. 2, p. 632-639.

Healy, R.W., and Ronan, A.D., 1996, Documentation of computer program VS2DH for simulation of energy transport variably saturated porous media-Modification of the U.S. Geological Survey's computer program VS2DT: U.S. Geological Survey Water-Resources Investigations Report 96-4230, 36 p.

Heath, R.C., 1983, Basic ground-water hydrology: U.S. Geological Survey Water-Supply Paper 2220, 84 p.

Hsieh, P.A., Wingle, W.L., and Healy, R.W., 2000, VS2DIA graphical software package for simulating fluid flow and solute or energy transport in variably saturated porous media: U.S. Geological Survey Water-Resources Investigations Report 99-4130, 16 p.

Lohman, S.W., 1979, Ground-water hydraulics: U.S. Geological Survey Professional Paper 708, 70 p.

Montana Bureau of Mines and Geology, 2011, Groundwater Information Center (GWIC) database, accessed February 15, 2011, at http://mgmggwic.mtech.edu/.

Montana Department of Natural Resources and Conservation , 2003, Smith River basin permit and change applications supplemental environmental assessment: Montana Department of Natural Resources and Conservation, Water Resources Division, Helena, MT, 78 p.

Montana Natural Resource Information System, 2010, Digital Atlas of Montana, accessed September 21, 2010, at http://maps2.nris.mt.gov/mapper/.
National Climatic Data Center, 2011, Annual Climatological Summary, accessed November 17, 2011 at http://cdo.ncdc. noaa.gov/ancsum/ACS? coban=248930.

Nilges, H.L. and Caldwell, R.R., 2012, Hydrologic data for the Smith River watershed, Montana, through water year 2010: U.S. Geological Survey Open-File Report 2012-1134, 41 p.

Niswonger, R.G., and Prudic, D.E., 2003, Modeling heat as a tracer to estimated streambed seepage and hydraulic conductivity, in Stonestrom, D.A. and Constantz, J., eds., Heat as a tool for studying movement in ground water near streams: U.S. Geological Survey Circular 1260, p. 81-89.

Nolan, K.M. and Shields, R.R., 2000, Measurement of stream discharge by wading: U.S. Geological Survey WaterResources Investigations Report 00-4036, on CD-ROM.

Oregon State University PRISM Group, 2006, United States Average or Annual Precipitation, 1971-2000: Corvallis, Oregon State University, accessed March 31, 2009 at http://www.prism.oregonstate.edu/.

Rantz, S.E., and others, 1982, Measurement and computation of streamflow: U.S. Geological Survey Water-Supply Paper 2175, 2 v. 631 p.

Ross, C.P., Andrews, D.A., and Witkind, J.A., compilers, 1955, Geologic map of Montana: U.S. Geological Survey, 2 sheets, scale 1:500,000.

Runkel, A.C., 1986, Geology and vertebrate paleontology of the Smith River basin, Montana: Unpublished Master's thesis, University of Montana, $80 \mathrm{p}$.

Sauer, V.B., and Meyer, R.W., 1992, Determination of error in individual discharge measurements: U.S. Geological Survey Open-File Report 92-144, 21 p.

Turnipseed, D.P., and Sauer, V.B., 2010, Discharge measurements of gaging stations: U.S. Geological Survey Techniques and Methods, book 3, chap. A8, 87 p.

U.S. Census Bureau, 2000, 2000 Census Block Population, accessed January 17, 2012 at http://maps2.nris.mt.gov/mapper/MapWindow.asp?Profile= 2006737\&Cmd=Build+Reports.

U.S. Geological Survey (USGS), 2000, National Land Cover Data for Montana, Vector Format, accessed 3/16/2009 at http://nris.mt.gov/nsdi/nris/nlcd/nlcdvector.asp.

U.S. Geological Survey (USGS), 2010. National Hydrography Dataset, accessed September 22, 2010 at http://nhd.usgs. gov/index.html. 
Appendixes 


\section{Appendix 1. Site-Identification Systems}

Groundwater sites (wells) are assigned a 15-digit site identification number; these numbers represent the approximate latitude and longitude of the site (first 13 digits) plus a sequence number (last 2 digits). Wells used for this study were also assigned a station name based on their geographic position within the rectangular grid system used for the subdivision of public lands (fig. 1-1). The station name consists of 14 characters. The first three characters specify the township and its position north $(\mathrm{N})$ of the baseline in Montana (for example, $09 \mathrm{~N}$ ). The next three characters specify the range and its position east (E) of the principal meridian in Montana (for example, 05E). The next two numbers represent the section number. The next four characters sequentially designate the quarter (160-acre tract), quarter-quarter (40-acre tract), quarter-quarter-quarter (10-acre tract), and the quarter-quarterquarter-quarter $\left(2 \frac{1}{2}\right.$-acre tract) of the section in which the well lies. The quarter subdivisions within a section are designated $\mathrm{A}, \mathrm{B}, \mathrm{C}$, and $\mathrm{D}$ in a counterclockwise direction, beginning in the northeast quadrant. The final two characters of the station name are a sequence number assigned to differentiate multiple wells within a single quarter-quarter-quarter-quarter section. For example, as shown in figure 1-1, 09N05E18BBAC01 was the first well inventoried in the SW1/4 of the NE1/4 of the NW1/4 of the NW1/4 of sec. 18, T. 09N., R. 05E.

Streamflow-gaging stations are typically assigned an eight-digit station identification number that represents the standard USGS numbering system for streamflow-gaging stations. Miscellaneous surface-water measurement sites are assigned a fifteen-digit station identification number similar to the site identification number of the groundwater sites. These numbers represent the approximate latitude and longitude of the site (first 13 digits), plus a sequence number (last 2 digits). Streamflow-gaging stations and miscellaneous surface-water measurement sites were also assigned a station name based on their geographic position relative to landmarks.

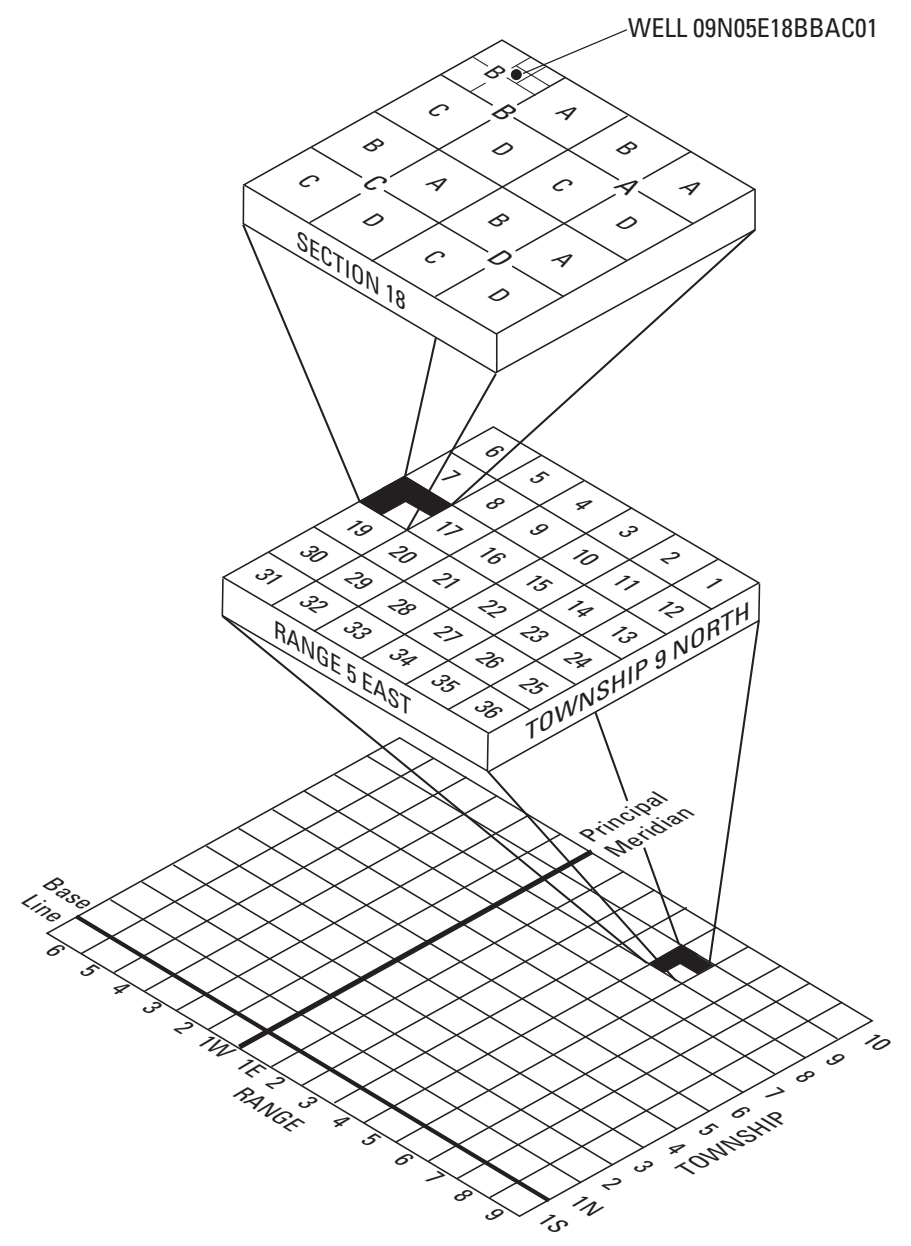

Figure 1-1. Location-numbering system for wells. 


\section{Appendix 2. Cross-Sectional Model Descriptions and Results}

Each two-dimensional fluid flow and energy (heat) transport VS2DH model for this study was constructed in a simplistic manner with consistent methodology for specifying boundary conditions. The grid system and boundary conditions representing the stream banks and stream bottom were similar among the models. All model grids were specified as uniform, 100 by 100 cell systems. Cell dimensions were $0.1 \mathrm{ft}$ vertically and 0.3 to $0.4 \mathrm{ft}$ horizontally. Average air temperature was used as the specified-temperature boundary representing the effects of soil temperature on groundwater and was applied to the area representing the stream banks (fig. 2-1) labeled soil. Streambeds were represented as specified-head and specified-temperature boundaries using measured water levels and stream temperature.
The side and bottom boundaries of each cross-sectional model are not hydrologic or flow-system boundaries. Boundaries on the left and right sides of the models were represented as specified head and specified-temperature boundaries using data from the monitoring wells located on each stream bank. Bottom boundaries were represented as specified-head and specified-temperature. The geometry of the bottom boundaries were based on a line that connected the lower-most data points (for example, the depth of the monitoring wells on each stream bank). The hydraulic properties of the Quaternary alluvium (for example, the vertical hydraulic conductivity, horizontal hydraulic conductivity, and porosity) were spatially uniform within the modeled area.

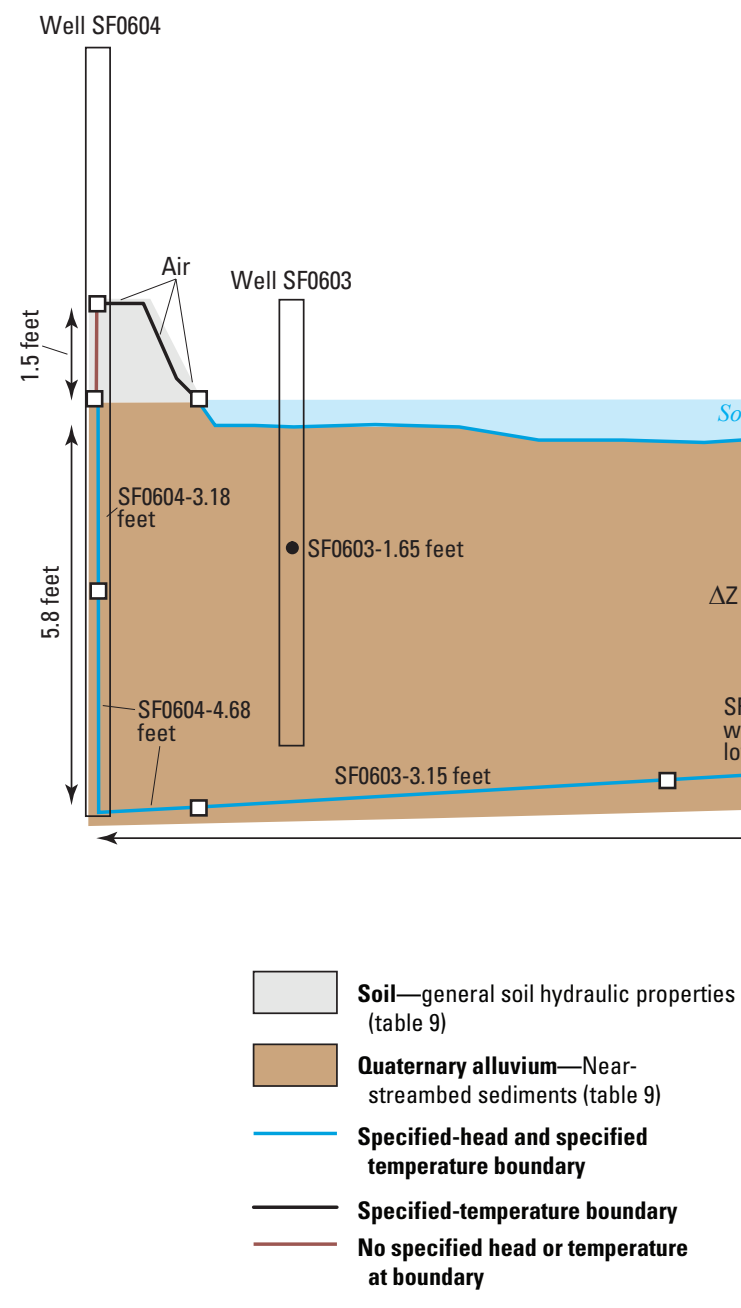

\section{EXPLANATION}

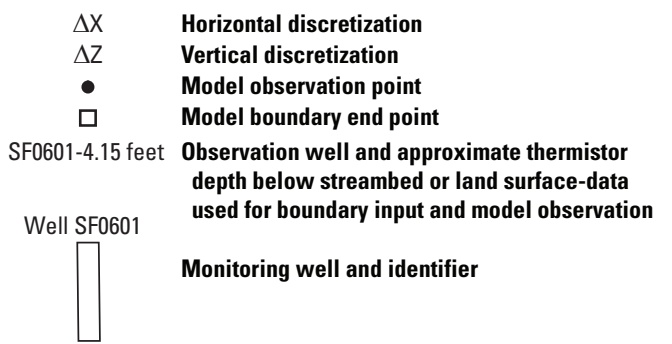

Figure 2-1. Boundary conditions and observation points for the VS2DH model, South Fork Smith River near mouth (station 06075785) monitoring site cross section. 


\section{South Fork Smith River near Mouth}

The South Fork Smith River near mouth (station 06075785) modeled cross section (site 3, fig. 8; fig. 2-1) is located on a gaining reach of the stream as apparent from the synoptic streamflow, water level, and temperature data. A 2-D model of the cross section was developed for the period of April 30 to November 30, 2008. The model configuration that most closely matched the simulated versus observed data was then run using data collected from April 21 to November 7, 2007 to determine if the selected parameters would yield acceptable data for a year with different hydrologic events.

The physical design of the VS2DH model is shown in figure 2-1. Temperature and water-level data from the stream bank wells (SF0604 and SF0602) were used for the specifiedhead and specified-temperature at the far left and right boundaries (fig. 2-1). The bottom boundary was divided into five segments. The far left and right segments (half the distance between the bank wells and the instream wells) were represented by using water level data from the left and right stream bank wells and temperature data from the deep thermistors (SF0604-4.68 ft and SF0602-4.15 ft) which were located about $3.0 \mathrm{ft}$ below the stream bottom. The remaining three segments of the bottom boundary were represented by using water level and temperature data from the instream wells near the left (SF0603-3.15 ft) and near the right (SF0602-4.15 ft) banks. The central segment was represented by using the average of the water level and temperature data from the deeper thermistors of the two instream wells. Daily temperature values from SF0602-4.15 ft were substituted for missing (September 11, 2008 through November 30, 2008) data from SF0601-4.15 ft. The SF0602-4.15 ft data appear to be a reasonable replacement for the missing SF0601-4.15 ft data since measured differences between the two sites were less than $0.4^{\circ} \mathrm{C}$ between April 30 and September 10, 2008.

Calibration of South Fork Smith River near mouth (station 06075785) cross sectional model proved difficult using a simple homogeneous characterization of the Quaternary alluvium. Of the cross sections simulated, results from this site had the poorest fit between the observed and simulated data. The best matches between the observed 2008 data and simulated values occurred with saturated hydraulic conductivity values of $3 \times 10^{-6} \mathrm{ft} / \mathrm{s}$ in both the horizontal and vertical directions (table 9, fig. 2-2).

Relatively cool 2007 summertime stream temperatures (cooler than average air temperature and streambed sediment measured in the monitoring wells) at this cross section indicated a component of the flow system that could not be represented accurately with the VS2DH model and the available data. The cool summertime stream temperatures were an indication of either the discharge of cool groundwater upstream from the cross section or an inflow of cooler groundwater that discharged into the stream through the unmonitored central part of the streambed. Temperatures near the stream banks, measured about $1.5 \mathrm{ft}$ below the streambed, were warmer than stream temperatures, whereas temperatures in the deeper thermistors (about $3.0 \mathrm{ft}$ below the streambed) at those wells were near that of the stream. Potentially, temperatures measured at the shallow near-bank thermistors (about $1.5 \mathrm{ft}$ below the streambed) indicate a component of shallow groundwater discharge to the stream (possibly local return flow from irrigation) that generally follows the trend of the local air temperature. A plausible explanation for the observed data would be that cooler groundwater at similar temperatures to the deeper thermistors (about $3.0 \mathrm{ft}$ below the streambed) was upwelling under the central part of the stream. A monitoring well under the central part of the stream would have aided in this interpretation.

\section{North Fork Smith River near Mouth}

The North Fork Smith River near the mouth (station 06075700) cross section (site 4, figs. 8 and 2-3) is on a primarily losing reach of the stream as apparent from water level, temperature, and synoptic streamflow data. A 2-D model of the cross section was developed for the period of April 26 to November 6, 2007. Groundwater levels at and near the stream banks indicated that unsaturated conditions between the streambed and the groundwater may occur at times, especially during 2007 (Nilges and Caldwell, 2012). The hydrologic conditions (saturated or unsaturated) near the center of the stream were unmeasured; therefore, it is possible that the saturated conditions did occur near the center of the stream but not along the banks. Unsaturated conditions affect the thermal conductivity of the sediment underlying the stream. The cross section was simulated as though saturated conditions existed. Differences in the observed versus simulated temperature values may be a result of the periods of unsaturated conditions (see below). The model configuration that most closely matched the simulated versus observed data was then run using data from a second season (April 30 to November 6,2008 ) to determine if the selected parameters would yield acceptable data for a year with different hydrologic events.

The physical design of the VS2DH cross-sectional model of the North Fork Smith River near mouth is shown in figure 2-3. The uppermost specified-head and specified-temperature on the far left and right boundaries used temperature and water-level data from the stream bank wells. The bottom boundary was split into three segments. The entire bottom boundary utilized temperature data from a nearby stock well at a depth $10 \mathrm{ft}$ below land surface. The bottom-boundary segments near the left and right sides were represented by the specified-head data from wells on the left (NF0604) and right (NF0601) banks. The middle third of the bottom specifiedhead boundary was set equal to the average of the stream bank wells. The temperature boundary conditions at the lower left and right boundaries (depths deeper than thermistors in the NF0601 and NF0604 wells) were calculated by averaging the temperatures of the stock well and the lower thermistors (depths of about $3 \mathrm{ft}$ below the streambed) in the bank wells (NF0601 and NF0604). 

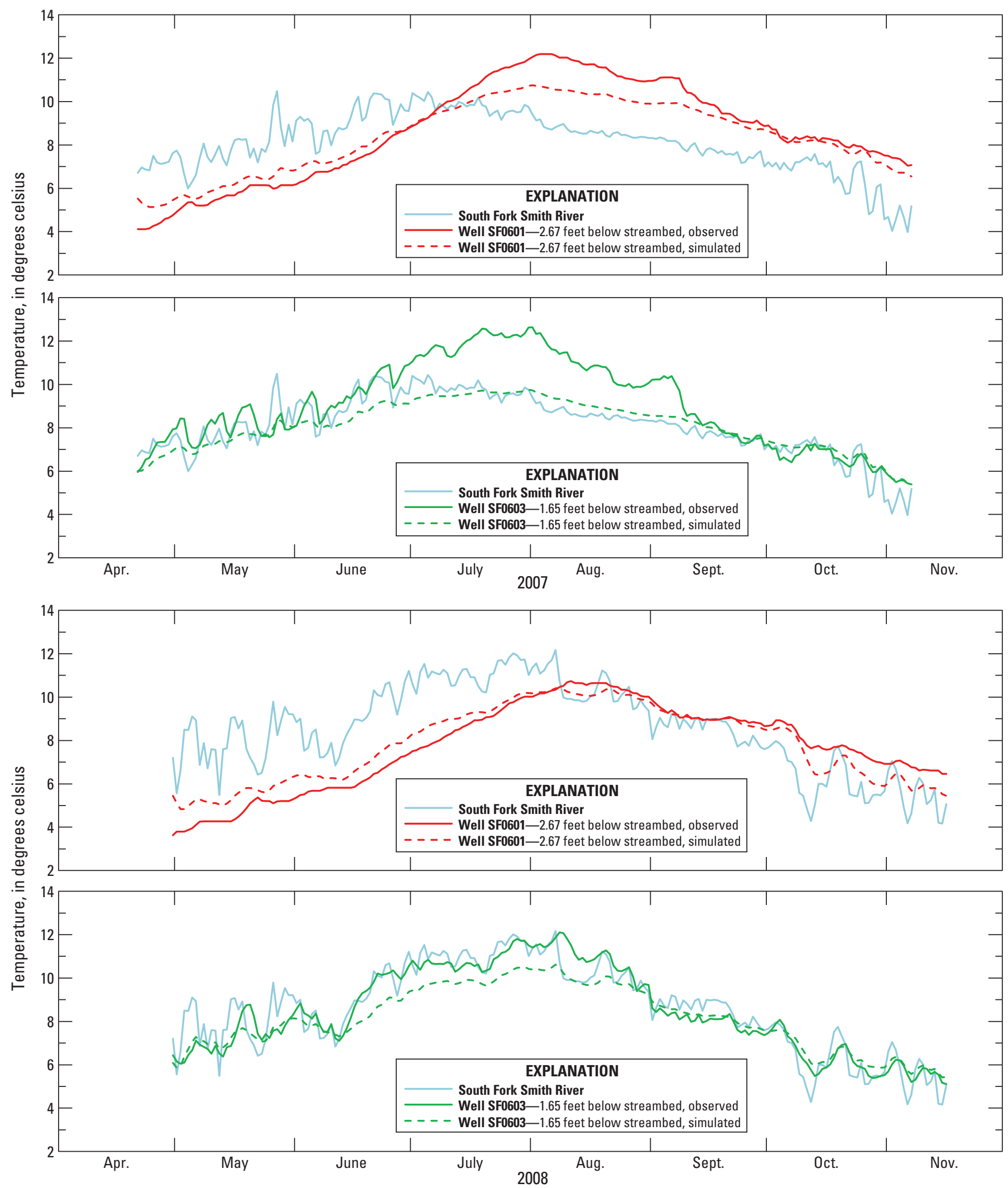

Figure 2-2. Observed and simulated temperature for the South Fork Smith River near mouth monitoring site (station 06075785), 2007 and 2008. (Horizontal and vertical hydraulic conductivities were set at $3 \times 10^{-6}$ feet per second.) 


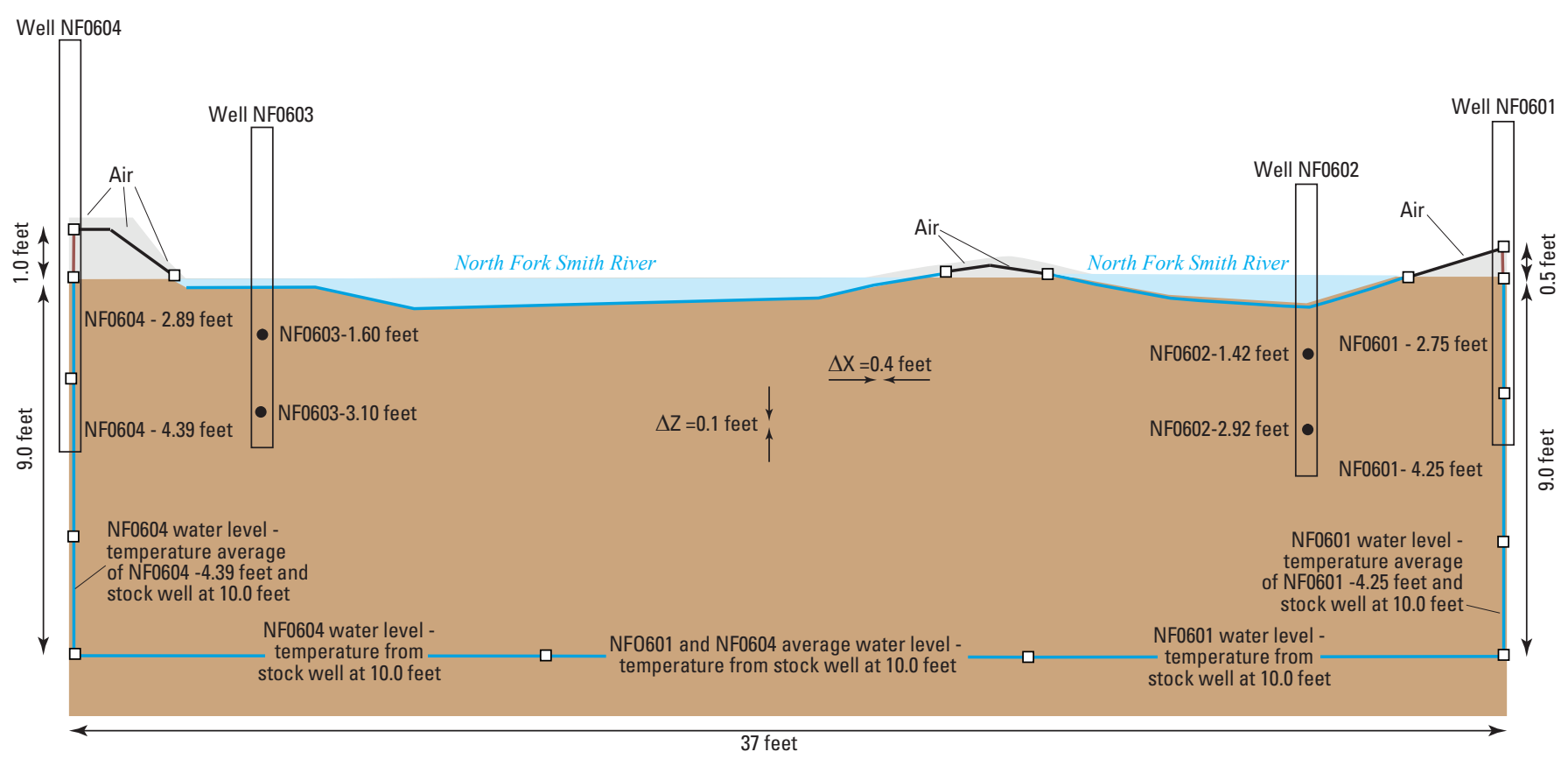

EXPLANATION
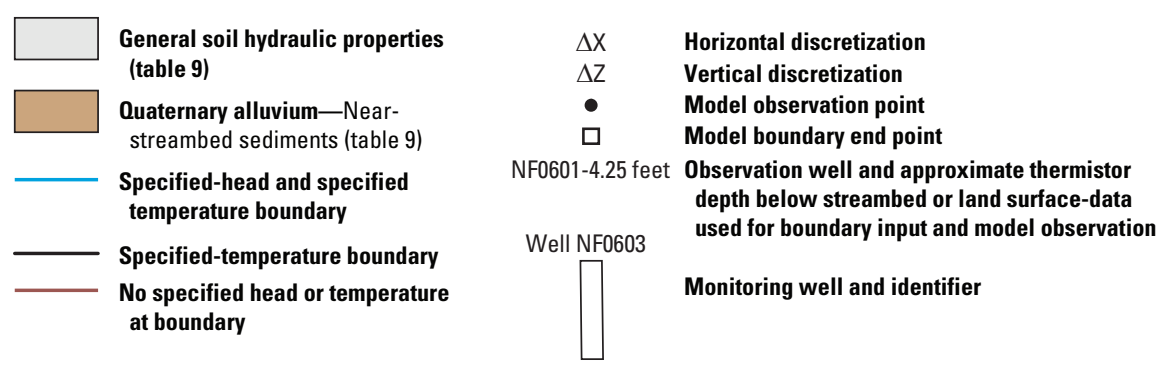

Figure 2-3. Boundary conditions and observation points for the VS2DH model, North Fork Smith River near mouth (station 06075700) monitoring site cross section.

Comparisons between the simulated and measured temperatures at the observation points for different hydraulic conductivities determined the best matches for both the 2007 and 2008 data occurred with saturated hydraulic conductivity equal to $3 \times 10^{-6} \mathrm{ft} / \mathrm{s}$ in both the horizontal and vertical direction (table 9, fig. 2-4). In most simulations, the right bank side (observation points NF0602-1.42ft and NF0602-2.92 ft) had observed temperatures closer to the simulated temperatures than on the left bank side. The greatest differences between observed and simulated temperatures occurred when groundwater levels fell below the streambed, especially for the temperature observations from the well near the left stream bank in 2007. The close match of observed and simulated temperatures on the right bank side indicates that flow from the stream to the groundwater is primarily within or parallel to the 2-D cross section and likely indicates (1) that conditions remained saturated or nearly saturated at that side, and (2) a greater quantity of water moved from the stream to the right bank side than from the stream to the left bank side. Water temperatures in the left bank well were typically cooler and the least dynamic (Nilges and Caldwell, 2012) which is likely associated with less leakage from the stream at that location.

\section{Smith River above Mud Springs Creek}

The Smith River above Mud Springs Creek (station 06075850) cross section (site 8, figs. 8 and 2-5) is on a reach of the stream that varied between losing and gaining conditions as indicated by the water level and temperature data. A 2-D model of the cross section was developed for the period of May 1 to November 30, 2008. The 2007 period was not simulated due to the lack of continuous stream stage data. The physical design of the VS2DH model is shown in figure 2-5. The specified-head and specified-temperature on the far left and right boundaries used temperature and water-level data 


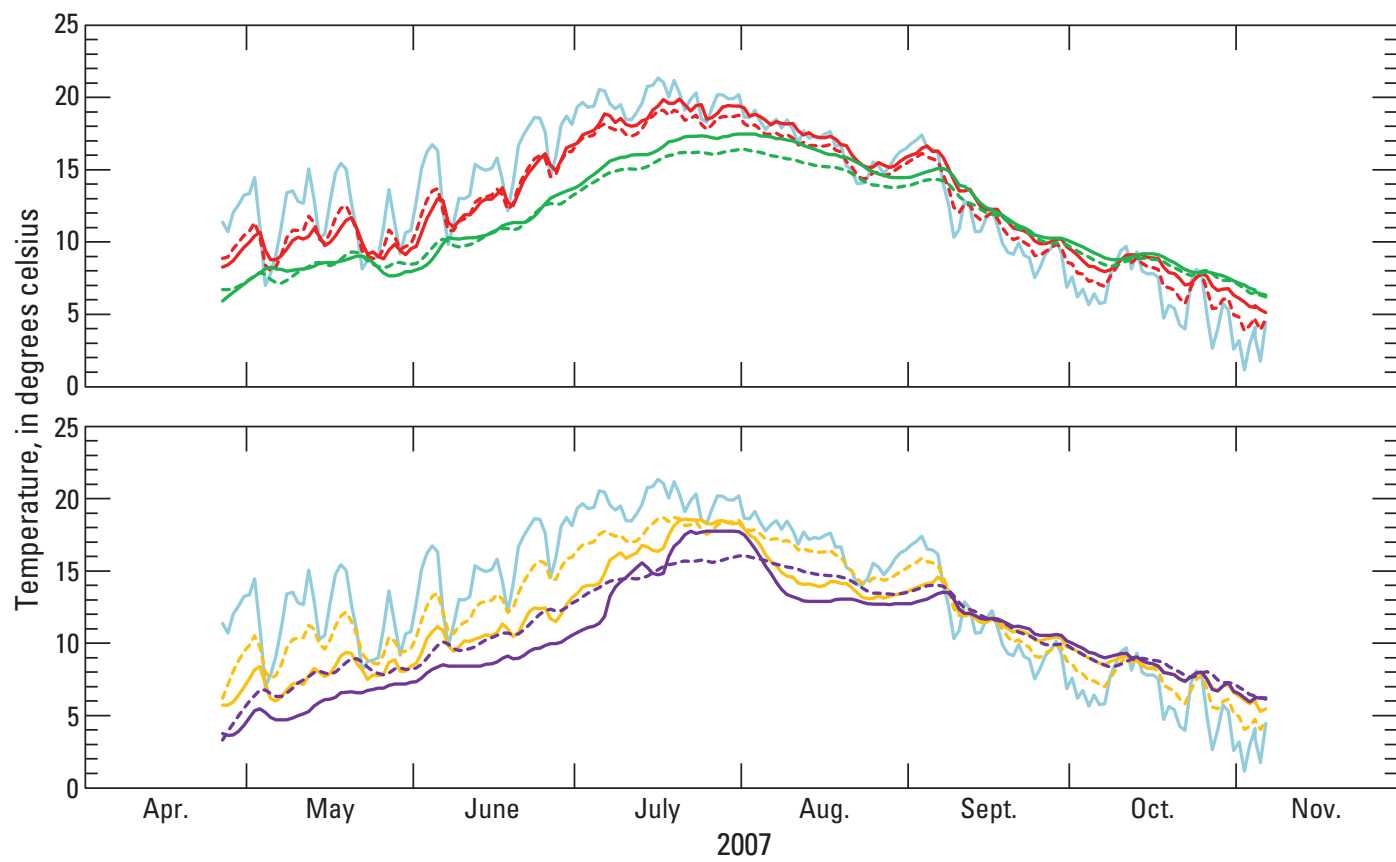

EXPLANATION

North Fork Smith River

Well NF0602-1.42 feet below streambed, observed

- Well NF0602-1.42 feet below streambed, simulated Well NF0602 - 2.92 feet below streambed, observed

- Well NF0602-2.92 feet below streambed, simulated

EXPLANATION

North Fork Smith River

Well NF0603-1.60 feet below streambed, observed

Well NF0603-1.60 feet below streambed, simulated Well NF0603-3.10 feet below streambed, observed

- Well NF0603-3.10 feet below streambed, simulated
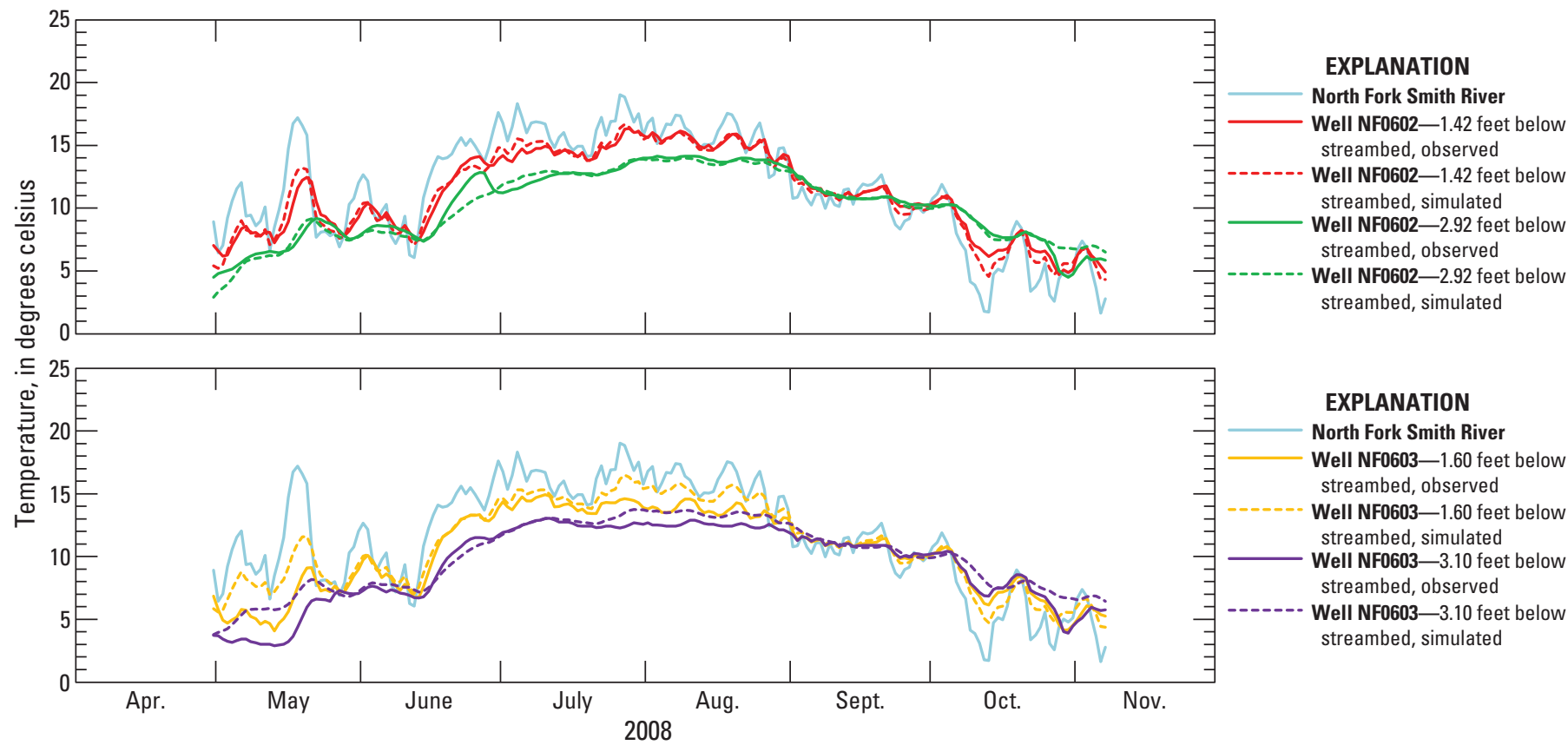

EXPLANATION

North Fork Smith River Well NF0603-1.60 feet below streambed, observed Well NF0603-1.60 feet below streambed, simulated Well NF0603-3.10 feet below streambed, observed Well NF0603-3.10 feet below streambed, simulated

Figure 2-4. Observed and simulated temperature for the North Fork Smith River near mouth monitoring site (station 06075700), 2007 and 2008. (Horizontal and vertical hydraulic conductivities were set at $3 \times 10^{-6}$ feet per second.) 


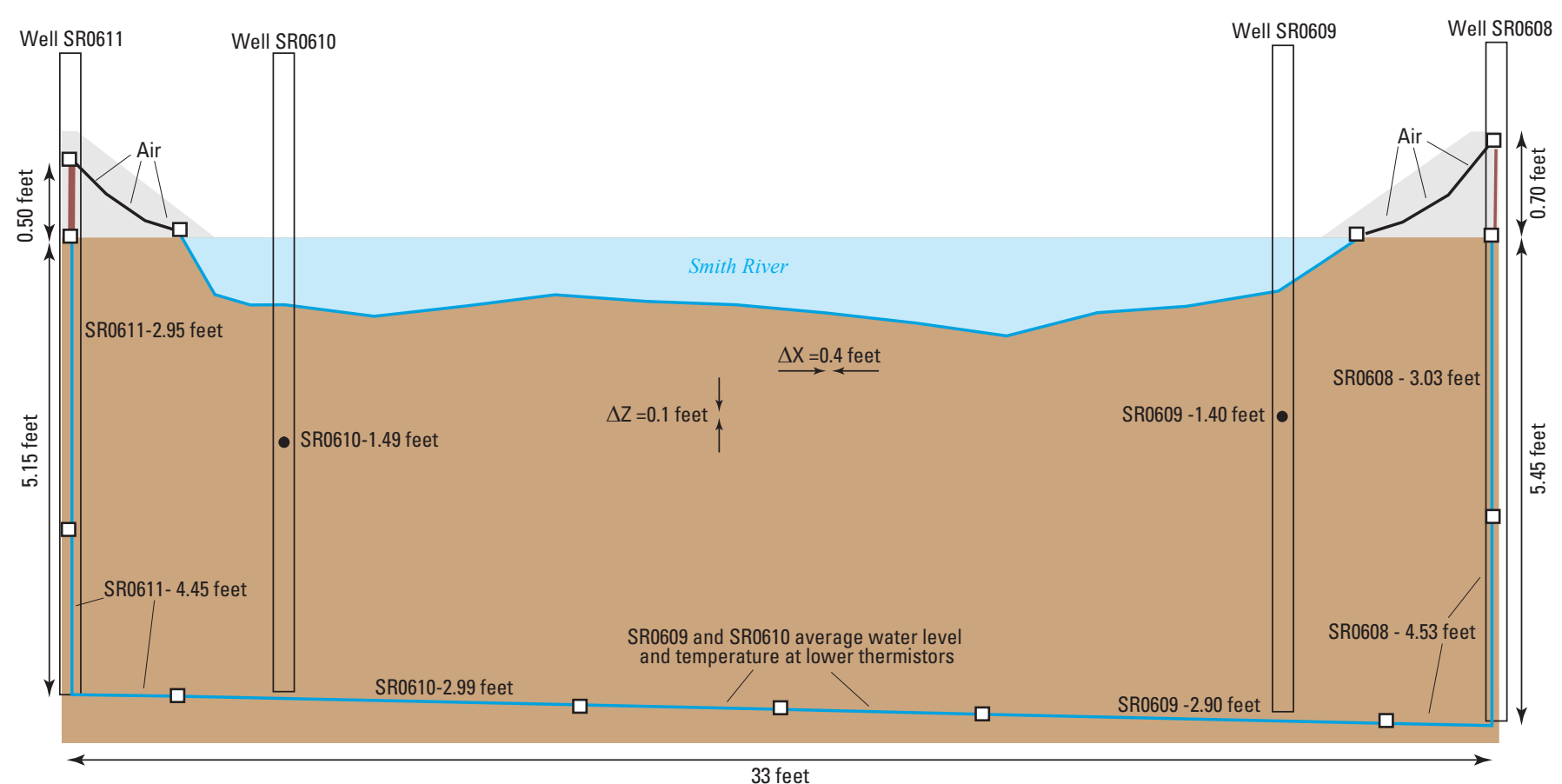

\section{EXPLANATION}
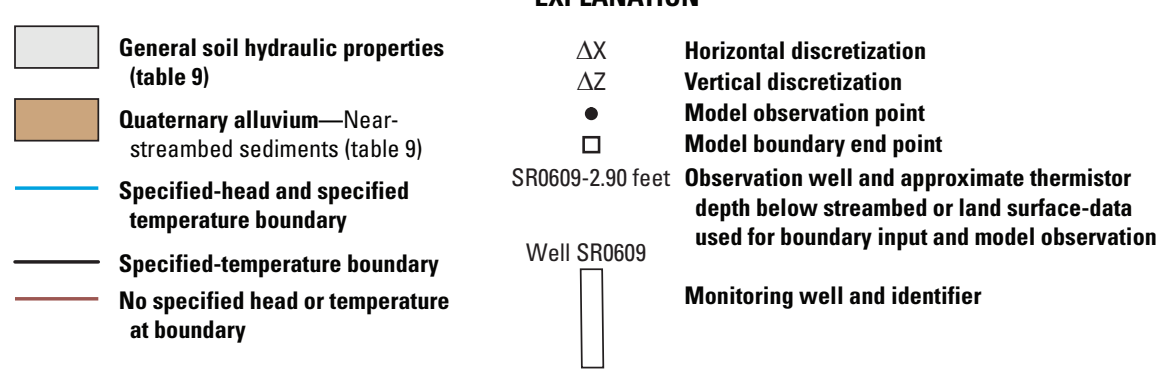

Figure 2-5. Boundary conditions and observation points for the VS2DH model, Smith River above Mud Springs Creek (station 06075850) monitoring site cross section.

from the stream bank wells (SR0608 and SR0611). The lower model boundary was represented with a combination of head data from both bank wells (SR0608 on right bank and SR0611 on left bank) and instream (SR0609 and SR0610) wells and temperature from the lower thermistors (SR0608-4.53 ft, SR0609-2.90 ft, SR0610-2.99 ft, and SR0611-4.45 ft) in those wells at about $3 \mathrm{ft}$ below the stream bottom. The central part of the lower boundary was represented by average water levels and temperatures of the instream wells (SR0609-2.90 ft and SR0610-2.99 ft).
Comparisons between the simulated and measured temperatures at the observation points for different hydraulic conductivities determined that the best matches for the 2008 data occured with saturated hydraulic conductivity equal to $4 \times 10^{-5} \mathrm{ft} / \mathrm{s}$ (roughly equivalent to a standard sandy loam) in both the horizontal and vertical directions (table 9 , fig. 2-6). Simulated temperatures at both the right bank side (observation point SR0609-1.4 ft) and left bank side (observation point SR0610-1.49 ft) closely matched the observed temperatures. 


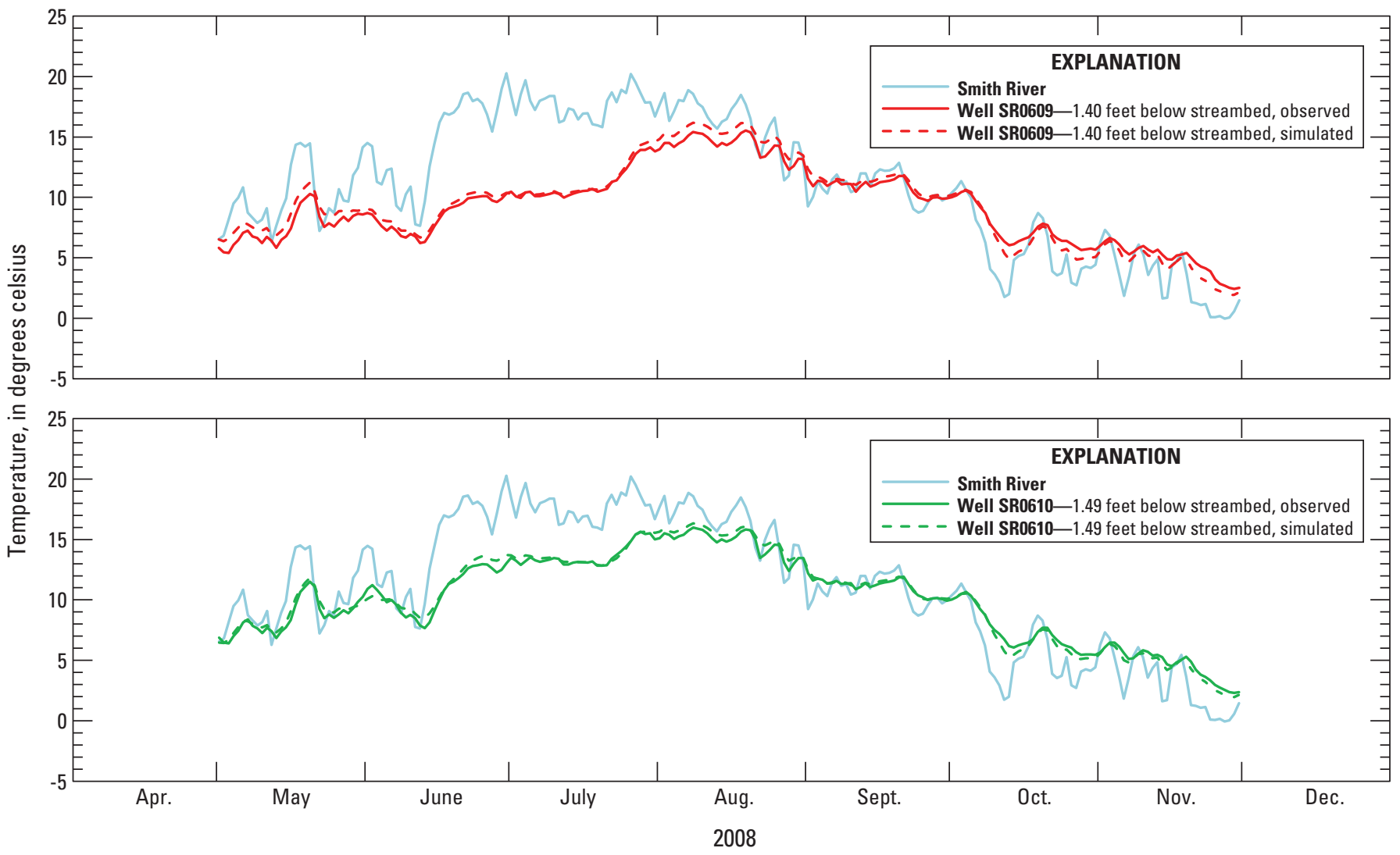

Figure 2-6. Observed and simulated temperatures for the Smith River above Mud Springs Creek monitoring site (station 06075850), 2008. (Horizontal and vertical hydraulic conductivities were set at $4 \times 10^{-5}$ feet per second.) 


\section{Appendix 3. Water Flux Calculations of Cross-Section Models}

The flow of water (water flux) across the streambed, bottom, and side boundaries of the models was calculated using the hydraulic characteristics determined from the calibrated 2-D heat and solute transport VS2DH models. Water flux calculated for each boundary represents the amount of water that flowed across the entire length of each boundary over a unit (1-ft) width. Flux values for the streambed boundary (blue lines, figs. 3-1-3-3) are shown as positive when water is moving from the groundwater to the stream and negative when water is moving from the stream to the groundwater. Flux estimates for the bottom and side boundaries (black, red, and purple lines, figs. 3-1-3-3) are positive when water is moving into the surrounding aquifer system and negative when the water is moving past the boundary into the stream.

\section{South Fork Smith River near Mouth}

The estimated daily flux of groundwater discharge to the stream across the streambed boundary was very similar in 2007 and 2008 at the South Fork Smith River near mouth (station 06075785; table 10; fig. 3-1) cross section; daily water-flux from the groundwater to the stream (noted as a positive values on fig. 3-1, blue line) ranged from a low of about $2.0 \mathrm{ft}^{3} / \mathrm{d}$ in both years to highs of about $3.1 \mathrm{ft}^{3} / \mathrm{d}(2007)$ and $3.4 \mathrm{ft}^{3} / \mathrm{d}$ (2008). The majority of the flux of groundwater to the stream (fig. 3-1B and 3-1C) appeared to flow across the bottom boundary (black line), followed by the left and right boundaries (red and purple lines, respectively). Temperature distributions within the model domain as well as the magnitude and direction of water flow for three selected dates are illustrated in figure 3-1D.

\section{North Fork Smith River near Mouth}

The estimated daily flux of stream water infiltrating to the groundwater at the North Fork Smith River near mouth cross section (station 06075700) was greater in 2007 than in 2008 (table 10; fig. 3-2). In 2007, water flux ranged from near zero (during a brief period of gaining groundwater in the stream) to near $-1.7 \mathrm{ft}^{3} / \mathrm{d}$ (noted as negative values, as the stream was losing water on fig. 3-2). In 2008, water flux ranged from short periods of groundwater discharged to the stream during early summer and fall, to about $-1.0 \mathrm{ft}^{3} / \mathrm{d}$ when water was flowing from the stream to the groundwater. Temperature distributions within the model domain as well as the magnitude and direction of water flow for three selected dates are illustrated in figure $3-2 D$.

The majority of the water appeared to exit the modeled system through the bottom boundary (black line; fig. 3-2B and $3-2 C)$. Water-flux rates through the left and right boundaries were very similar (red and purple lines, respectively; fig. 3-2B and $3-2 C$ ). Water flux from the stream to the groundwater increased incrementally from mid-May through early September in 2007 (fig. 3-2B). Flux from the stream to the groundwater was more variable in 2008, with the highest flux rates occurring in May and early August (fig. 3-2C).

\section{Smith River above Mud Springs Creek}

The direction and magnitude of daily flux of water changed dramatically during the period of record coincident with the occurrence of local flood irrigation at the Smith River above Mud Springs Creek cross section (station 06075850; table 10; fig. 3-3). Estimated daily flux of water ranged from about $-2.7 \mathrm{ft}^{3} / \mathrm{d}$ in the spring, during the highest rates of flow from the stream to the groundwater, to $9.8 \mathrm{ft}^{3} / \mathrm{d}$ during the summer when groundwater discharged to the stream (fig. 3-3B). Temperature distributions within the model domain as well as the magnitude and direction of water flow for three selected dates are illustrated in figure 3-3C. 
$\boldsymbol{A}$

$$
\stackrel{ \pm}{\Xi}
$$

Streambed

Model domain

Bottom

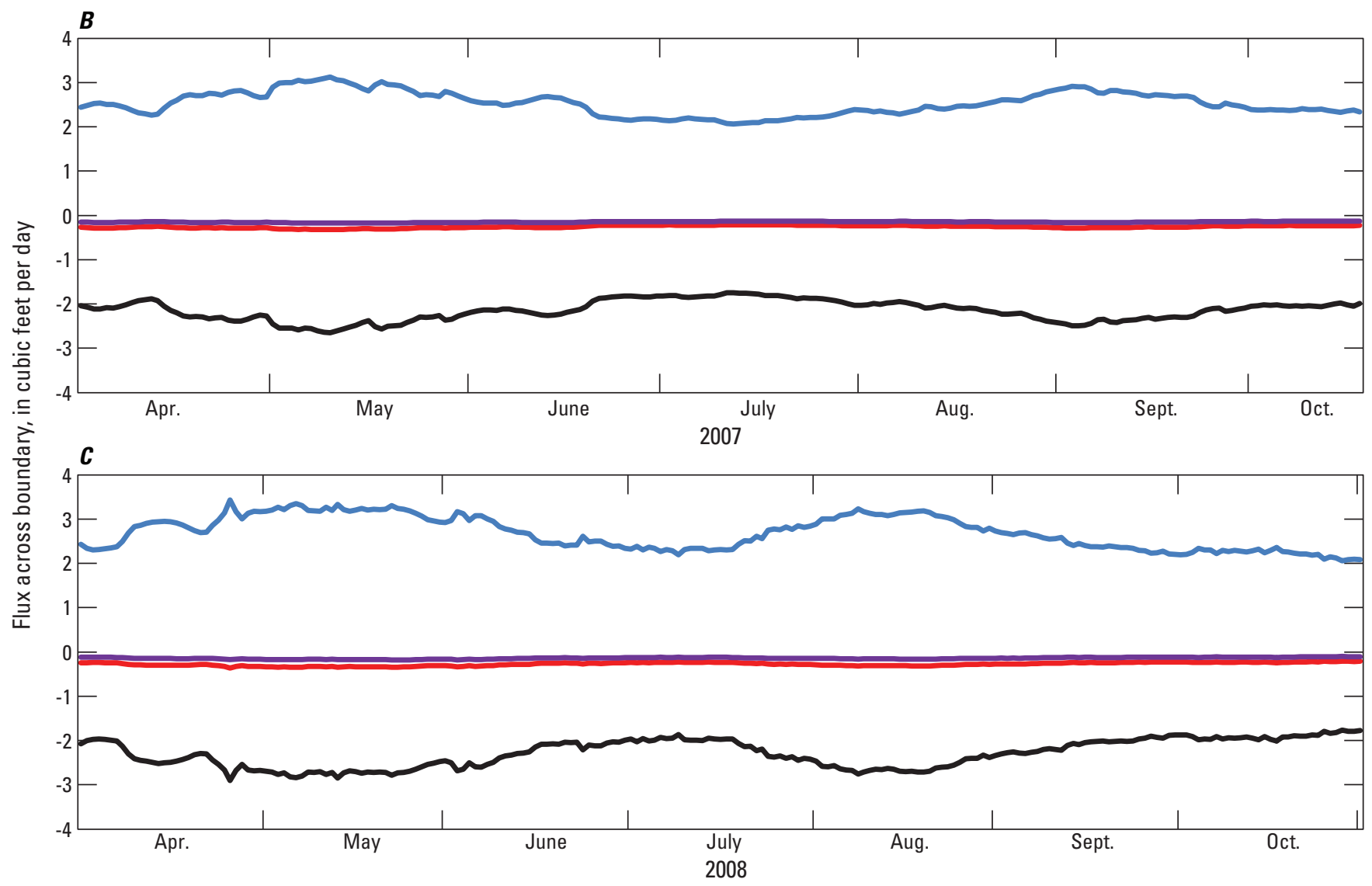

EXPLANATION

Model domain boundaries

Streambed

$\longrightarrow$ Bottom

$\longrightarrow$ Right

Figure 3-1. Water-flux information, in cubic feet per day ( $\left.\mathrm{ft}^{3} / \mathrm{d}\right)$, for the South Fork Smith River near mouth (station 06075785) modeled cross section. $A$, Location of model boundaries; $B$, Daily flux across model boundaries, 2007; C, Daily flux across model boundaries, 2008; and $D$, Simulated temperature distributions inside the model domain on three selected dates (arrows indicate direction and magnitude of water flux). Flux estimates for the streambed boundary (blue lines) are shown as positive when water is moving from the groundwater system to the stream and negative when moving from the stream to the groundwater system. Flux estimates from the bottom and side boundaries (black, red, and purple lines) are positive when the water flux is into the surrounding groundwater system and negative when the water flux past the boundary is into the stream. 

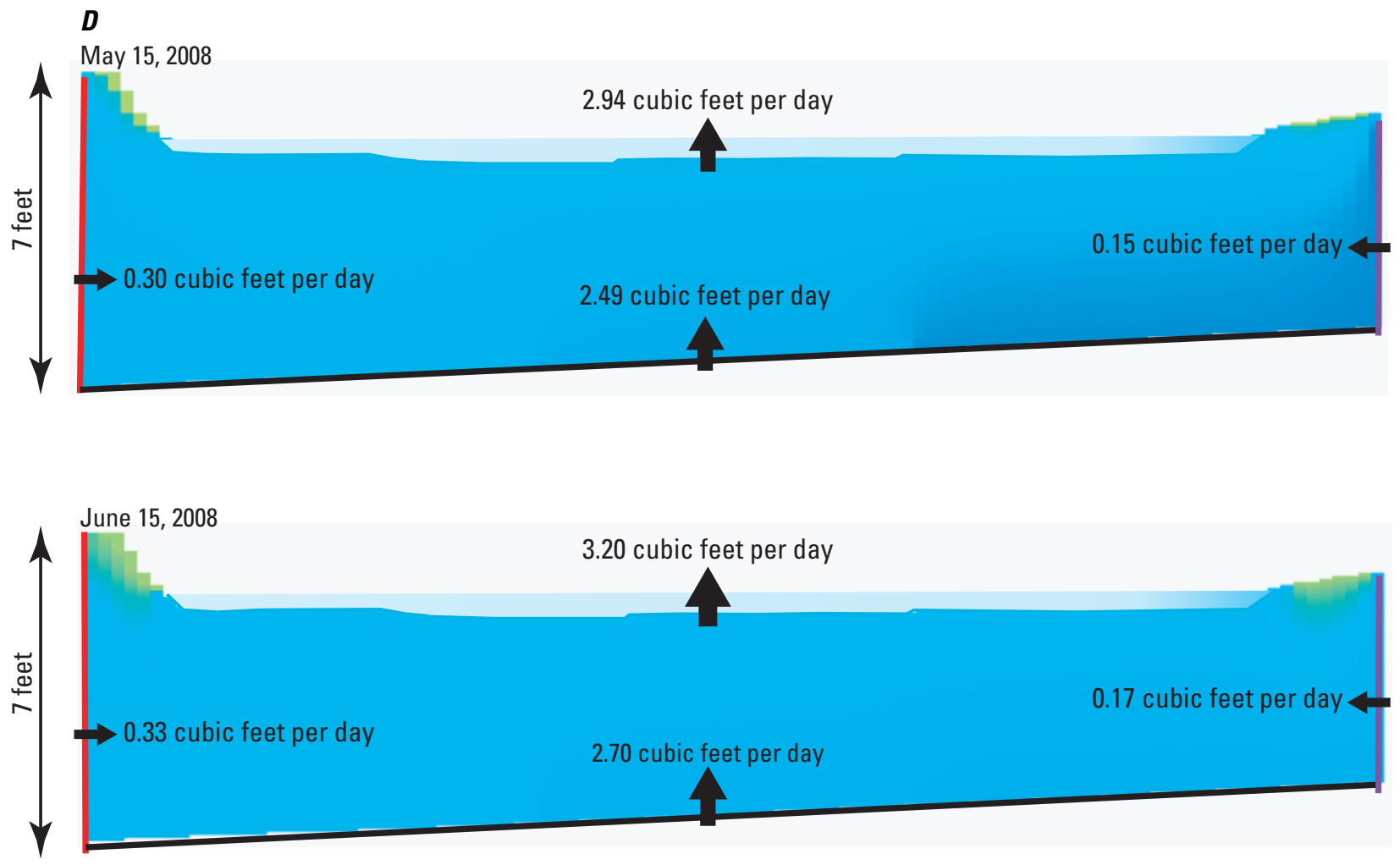

1.97 cubic feet per day

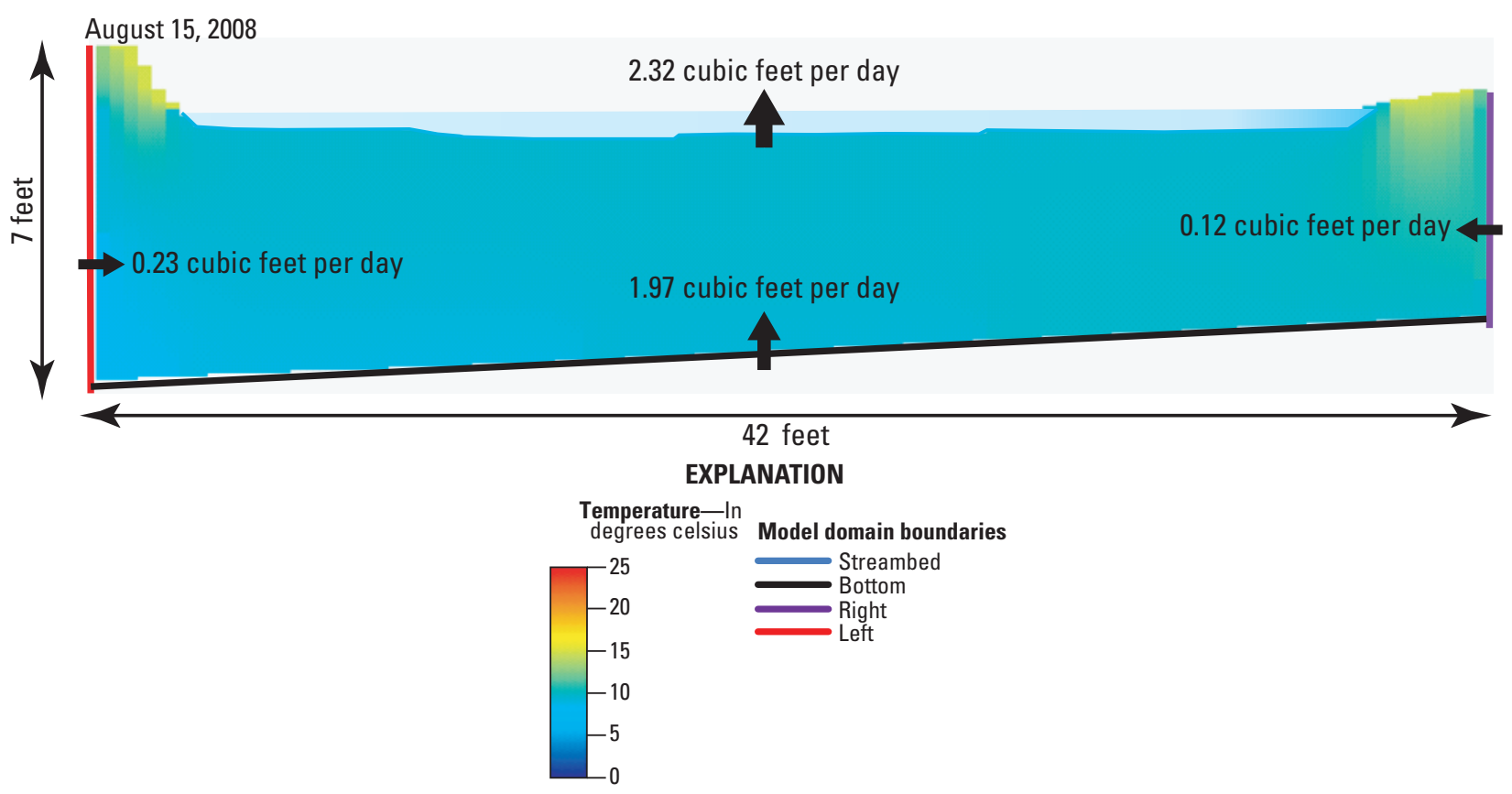

Figure 3-1. Water-flux information, in cubic feet per day ( $\left.\mathrm{ft}^{3} / \mathrm{d}\right)$, for the South Fork Smith River near mouth (station 06075785 ) modeled cross section. $A$, Location of model boundaries; $B$, Daily flux across model boundaries, 2007; $C$, Daily flux across model boundaries, 2008; and $D$, Simulated temperature distributions inside the model domain on three selected dates (arrows indicate direction and magnitude of water flux). Flux estimates for the streambed boundary (blue lines) are shown as positive when water is moving from the groundwater system to the stream and negative when moving from the stream to the groundwater system. Flux estimates from the bottom and side boundaries (black, red, and purple lines) are positive when the water flux is into the surrounding groundwater system and negative when the water flux past the boundary is into the stream.-Continued 
A
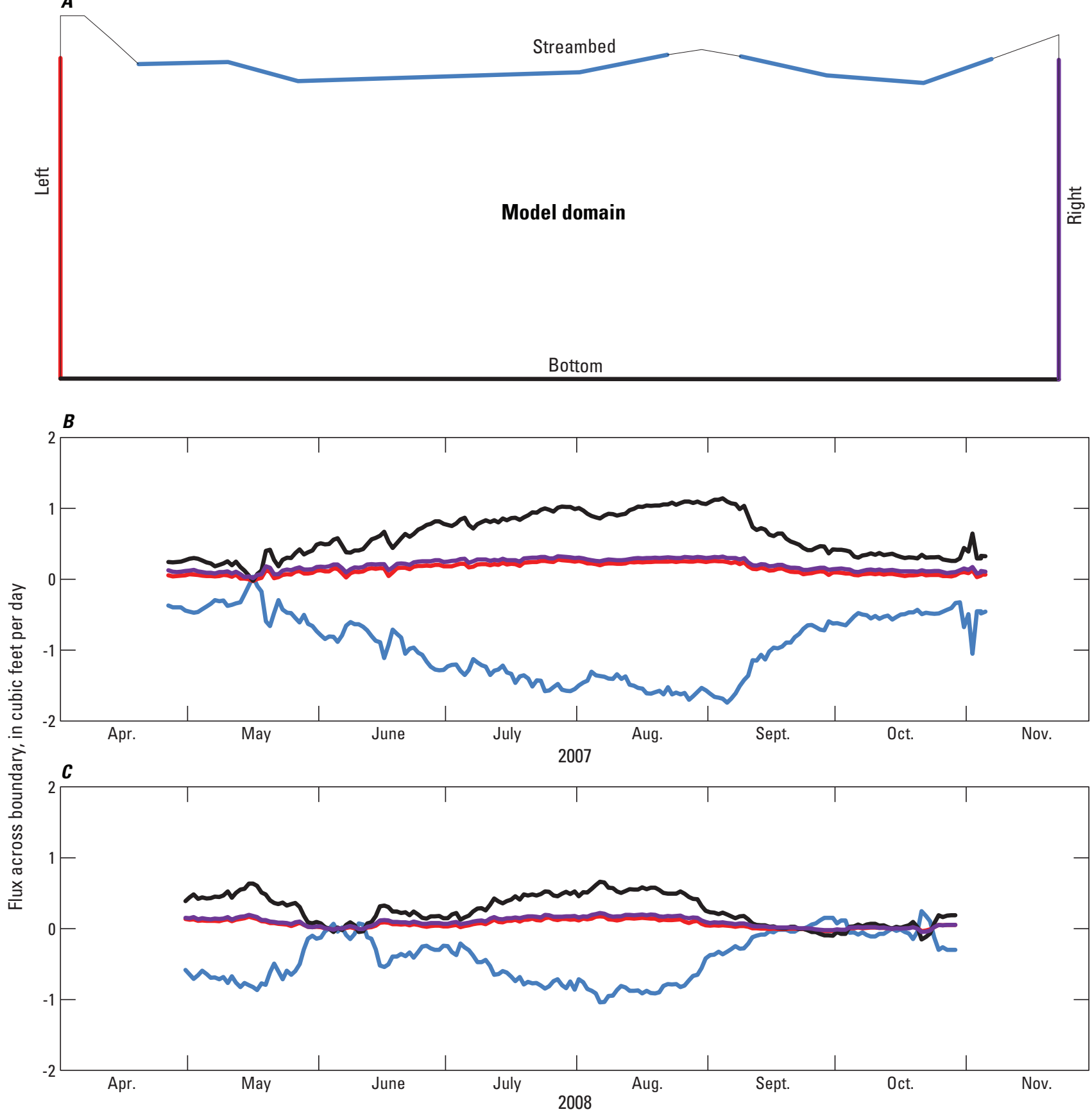

\section{EXPLANATION}

Model domain boundaries Streambed

Bottom

rand

型

Figure 3-2. Water-flux information, in cubic feet per day $\left(\mathrm{ft}^{3} / \mathrm{d}\right)$, for the North Fork Smith River near mouth (station 06075700) modeled cross section. $A$, Location of model boundaries; $B$, Daily flux across model boundaries, 2007; $C$, Daily flux across model boundaries, 2008; and $D$, Simulated temperature distributions inside the model domain on three selected dates (arrows indicate direction of water flux). Flux estimates for the streambed boundary (blue lines) are shown as positive when water is moving from the groundwater system to the stream and negative when moving from the stream to the groundwater system. Flux estimates for the bottom and side boundaries (black, red, and purple lines) are positive when the water flux is into the surrounding groundwater system and negative when the water flux past the boundary is into the stream. 

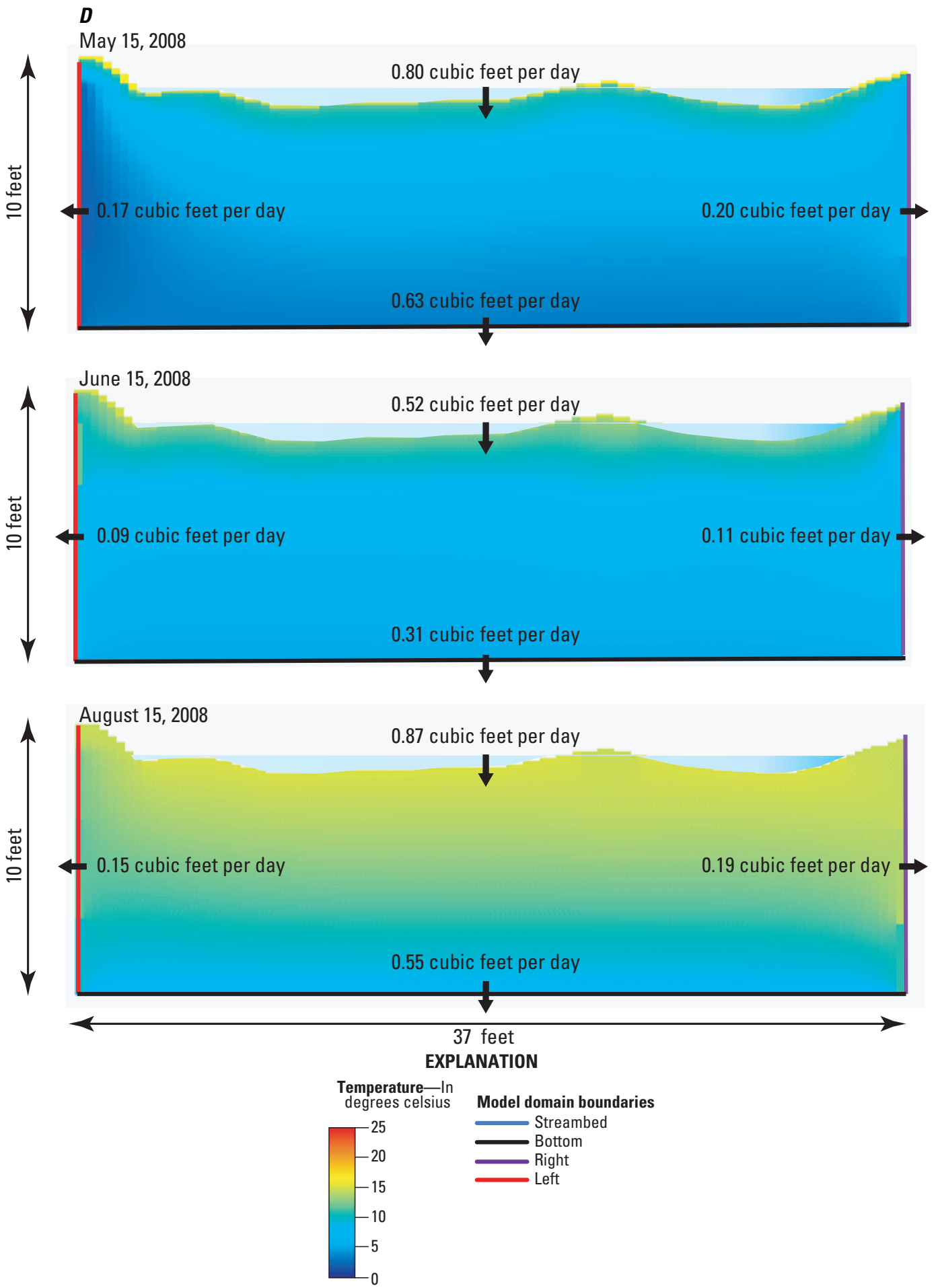

Figure 3-2. Water-flux information, in cubic feet per day $\left(\mathrm{ft}^{3} / \mathrm{d}\right)$, for the North Fork Smith River near mouth (station 06075700) modeled cross section. $A$, Location of model boundaries; $B$, Daily flux across model boundaries, 2007; $C$, Daily flux across model boundaries, 2008; and $D$, Simulated temperature distributions inside the model domain on three selected dates (arrows indicate direction of water flux). Flux estimates for the streambed boundary (blue lines) are shown as positive when water is moving from the groundwater system to the stream and negative when moving from the stream to the groundwater system. Flux estimates for the bottom and side boundaries (black, red, and purple lines) are positive when the water flux is into the surrounding groundwater system and negative when the water flux past the boundary is into the stream.-Continued 


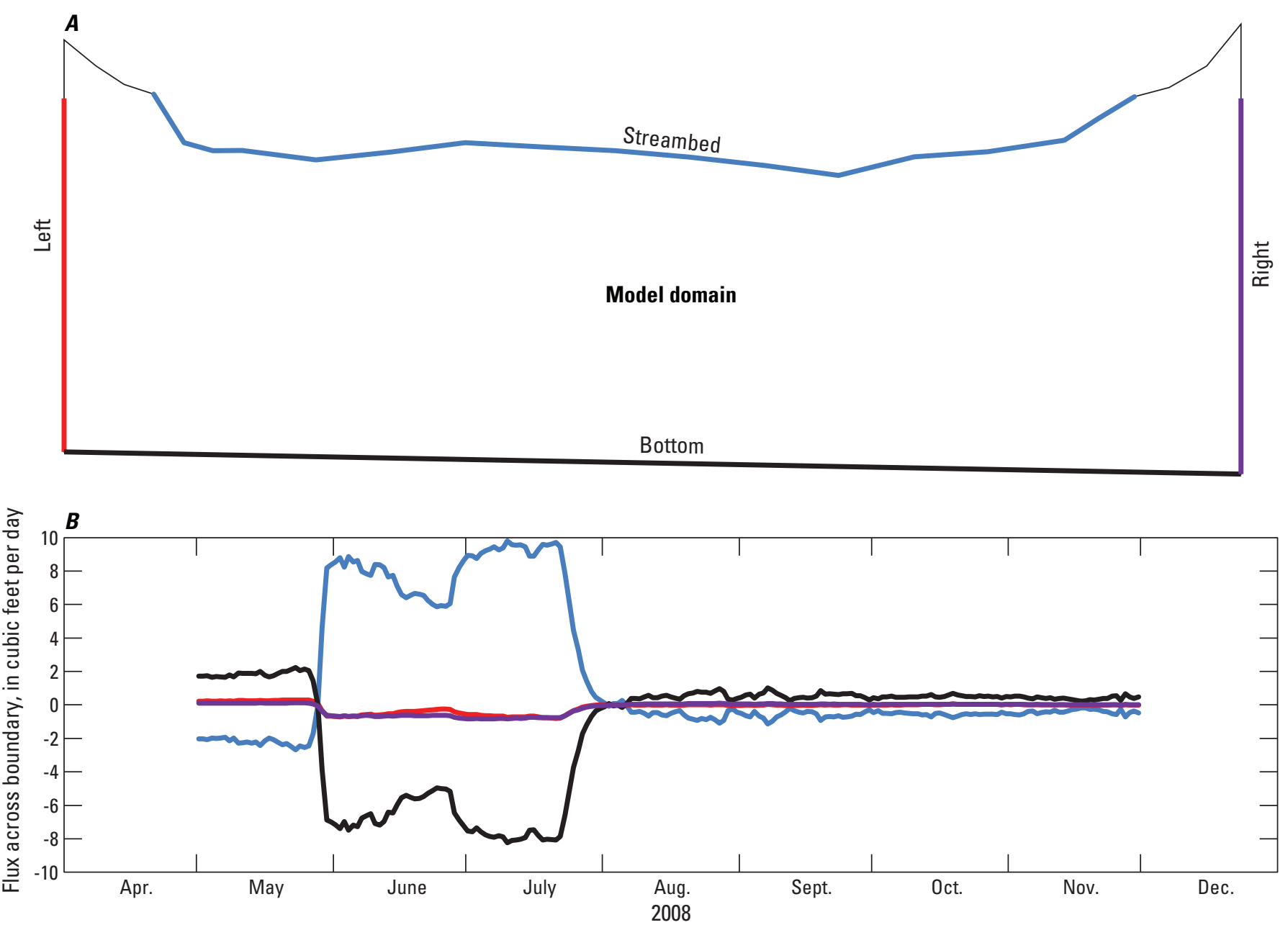

\section{EXPLANATION}

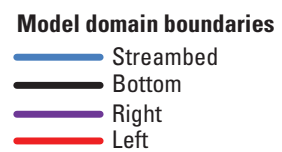

Figure 3-3. Water-flux information, in cubic feet per day (ft/d), for the Smith River above Mud Springs Creek (station 06075850) modeled cross section. $A$, Location of model boundaries; $B$, Daily flux across model boundaries, 2008; and $C$, Simulated temperature distributions inside the model domain on three selected dates (arrows indicate direction of water flux). Flux estimates for the streambed boundary (blue lines) are shown as positive when water is moving from the groundwater system to the stream and negative when moving from the stream to the groundwater system. Flux estimates for the bottom and side boundaries (black, red, and purple lines) are positive when the water flux is into the surrounding groundwater system and negative when the water flux past the boundary is into the stream. 

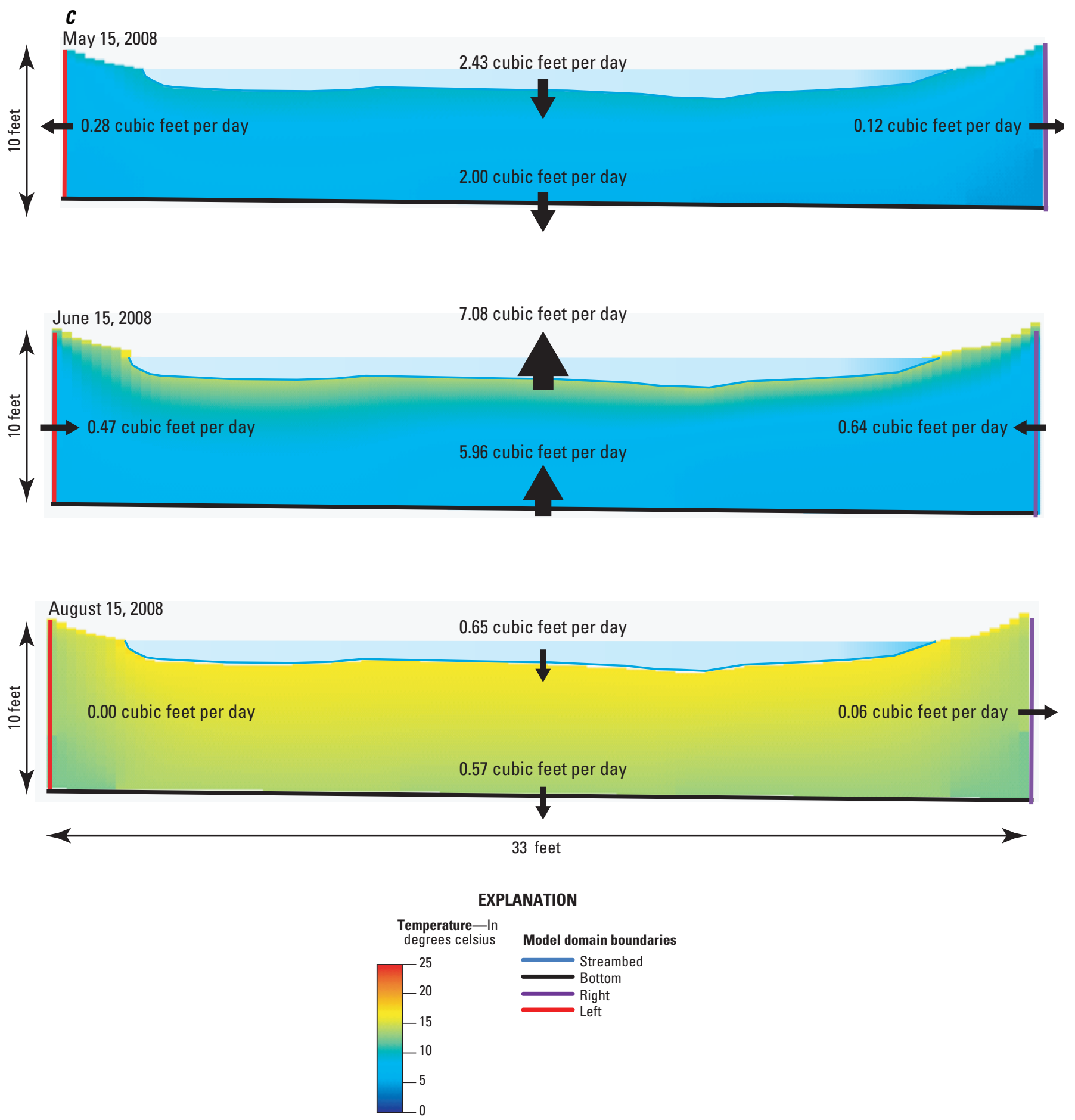

Figure 3-3. Water-flux information, in cubic feet per day $\left(\mathrm{ft}^{3} / \mathrm{d}\right)$, for the Smith River above Mud Springs Creek (station 06075850) modeled cross section. $A$, Location of model boundaries; $B$, Daily flux across model boundaries, 2008; and $C$, Simulated temperature distributions inside the model domain on three selected dates (arrows indicate direction of water flux). Flux estimates for the streambed boundary (blue lines) are shown as positive when water is moving from the groundwater system to the stream and negative when moving from the stream to the groundwater system. Flux estimates for the bottom and side boundaries (black, red, and purple lines) are positive when the water flux is into the surrounding groundwater system and negative when the water flux past the boundary is into the stream.-Continued 


\section{Appendix 4. Cross-Sectional Model Sensitivity Analysis}

The cross-sectional models developed for this study clearly have uncertainty and error. Numerical models of groundwater flow are limited in their representation of the physical system because they contain simplifications and assumptions of uncertain validity. Results from groundwaterflow models have a degree of uncertainty because detailed distributions of aquifer parameters are rarely available. Limitations in the numerical models that may cause errors in the results can be caused by (1) invalid assumptions or approach implemented by the numerical simulation code, and (2) inaccurate conceptual model, aquifer parameters, boundary conditions, or initial conditions. Sensitivity to (2) was evaluated as part of this analysis.

Modifications to the calibrated models selected for each cross section were conducted in order to examine model sensitivity and uncertainty to variations in aquifer characteristics. Aquifer characteristics of selected calibrated models were modified by (1) adjusting hydraulic conductivity (in both the horizontal and vertical directions) an order of magnitude lower and higher and (2) adjusting the ratio of vertical to horizontal hydraulic conductivity. In addition, water-flux values were calculated for each modeled section to examine the sensitivity of water-flux values to changes in model parameters. Simulated temperatures were sensitive to changes in hydraulic conductivity and the ratios of vertical to horizontal hydraulic conductivity at each of the modeled sections. The spatial variation of hydraulic characteristics within cross sections were not examined as part of the sensitivity analysis, but were examined during model calibration (see Model — South Fork Smith River near mouth). Better agreements between observed versus simulated temperatures could be achieved by spatially adjusting hydraulic properties in the model (for example, higher hydraulic conductivity values on one side and lower on the other), but this was not implemented because of the lack of subsurface data.
The models were sensitive to changes in hydraulic conductivity and ratios of vertical to horizontal hydraulic conductivity. As an example, figure 4-1 illustrates the measured temperatures at the observation points of the Smith River above Mud Springs Creek cross section and the simulated temperatures for the calibrated model (hydraulic conductivity $4 \times 10^{-5}$ $\mathrm{ft} / \mathrm{s}$ ) and simulated temperatures after adjusting the overall hydraulic conductivity and the ratio of horizontal to vertical hydraulic conductivity. During periods of small hydraulic gradients, the simulated and observed temperatures remained relatively similar for the models in which the overall hydraulic conductivity was adjusted. As hydraulic gradients increased during the gaining periods, simulated temperatures differed from observed temperatures by up to $4^{\circ} \mathrm{C}$. The lower hydraulic conductivity resulted in increased simulated temperatures relative to the observed temperatures during the gaining period and higher conductivity values resulted in lower observed temperatures during the gaining period. Adjustment of the vertical to horizontal hydraulic conductivity ratio from 1:1 to $1: 2$ and $1: 5$ generally overestimated temperatures by up to $3^{\circ} \mathrm{C}$ during the gaining periods.

Adjustments to the hydraulic conductivity of the calibrated or best-fit models resulted in substantial changes in water-flux values at the modeled cross sections. For example, reducing or increasing the overall hydraulic conductivity of the models by an order of magnitude resulted in an overall increase or decrease of the flux values by an order of magnitude, respectively. Adjusting ratios of vertical to horizontal hydraulic conductivity from 1:1 to $1: 2$ and 1:5 reduced calculated monthly mean flux rates by about 50 to 70 percent. As suggested by the sensitivity analysis of these models to variations in aquifer characteristics, additional analysis of aquifer characteristics at these modeled sections would increase the confidence in the model results. 


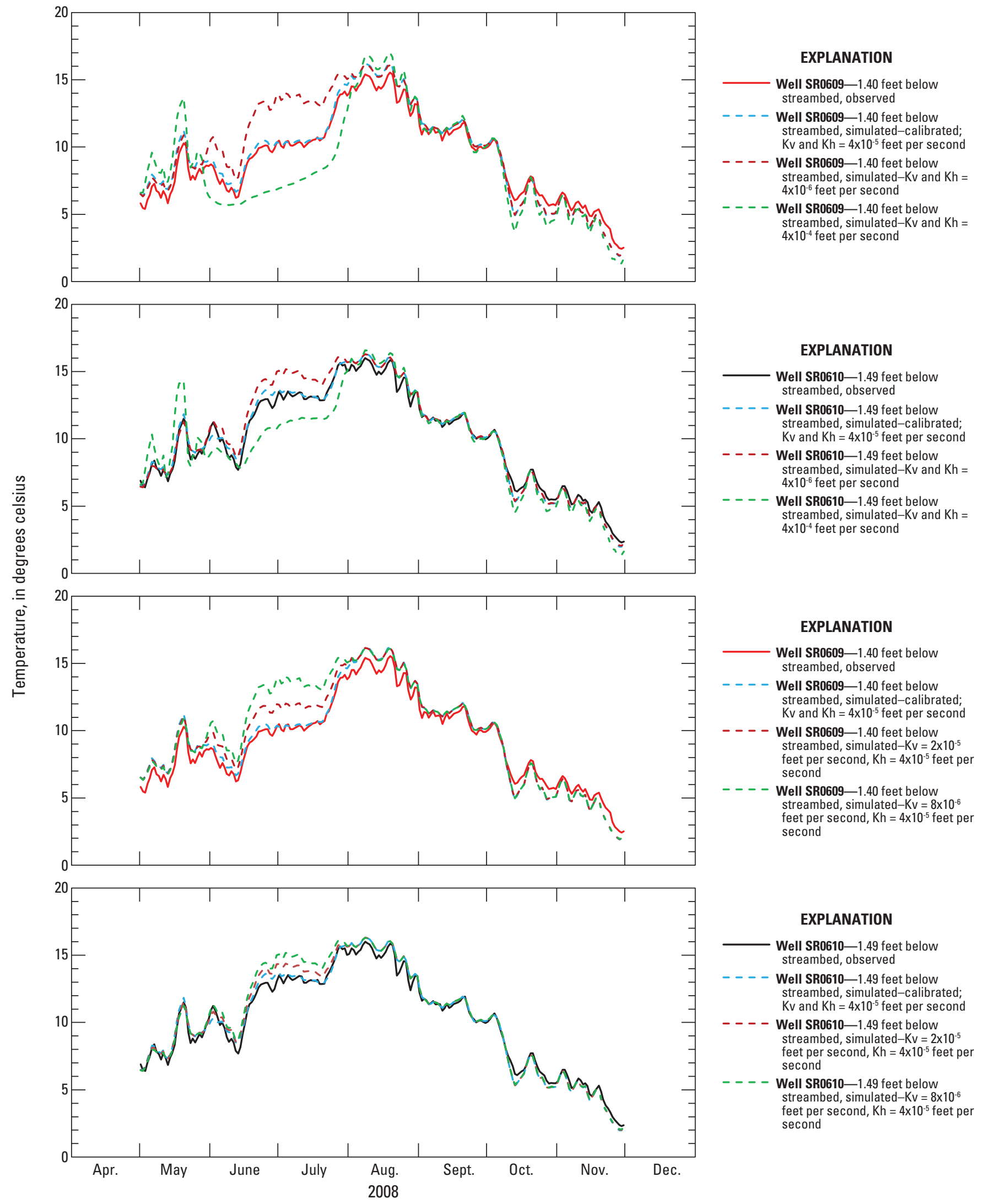

Figure 4-1. Observed and simulated temperatures with varied hydraulic conductivity values and ratios of vertical (Kv) to horizontal (Kh) hydraulic conductivity of the VS2DH 2-dimensional model of the Smith River above Mud Springs Creek monitoring site (station $06075850), 2008$. 
Publishing support provided by:

Denver Publishing Service Center

For more information concerning this publication, contact: Director, Montana Water Science Center

U.S. Geological Survey

3162 Bozeman Ave.

Helena, Montana 59601

(406) 457-5900

Or visit the Montana Water Science Center Web site at: http://mt.water.usgs.gov/ 


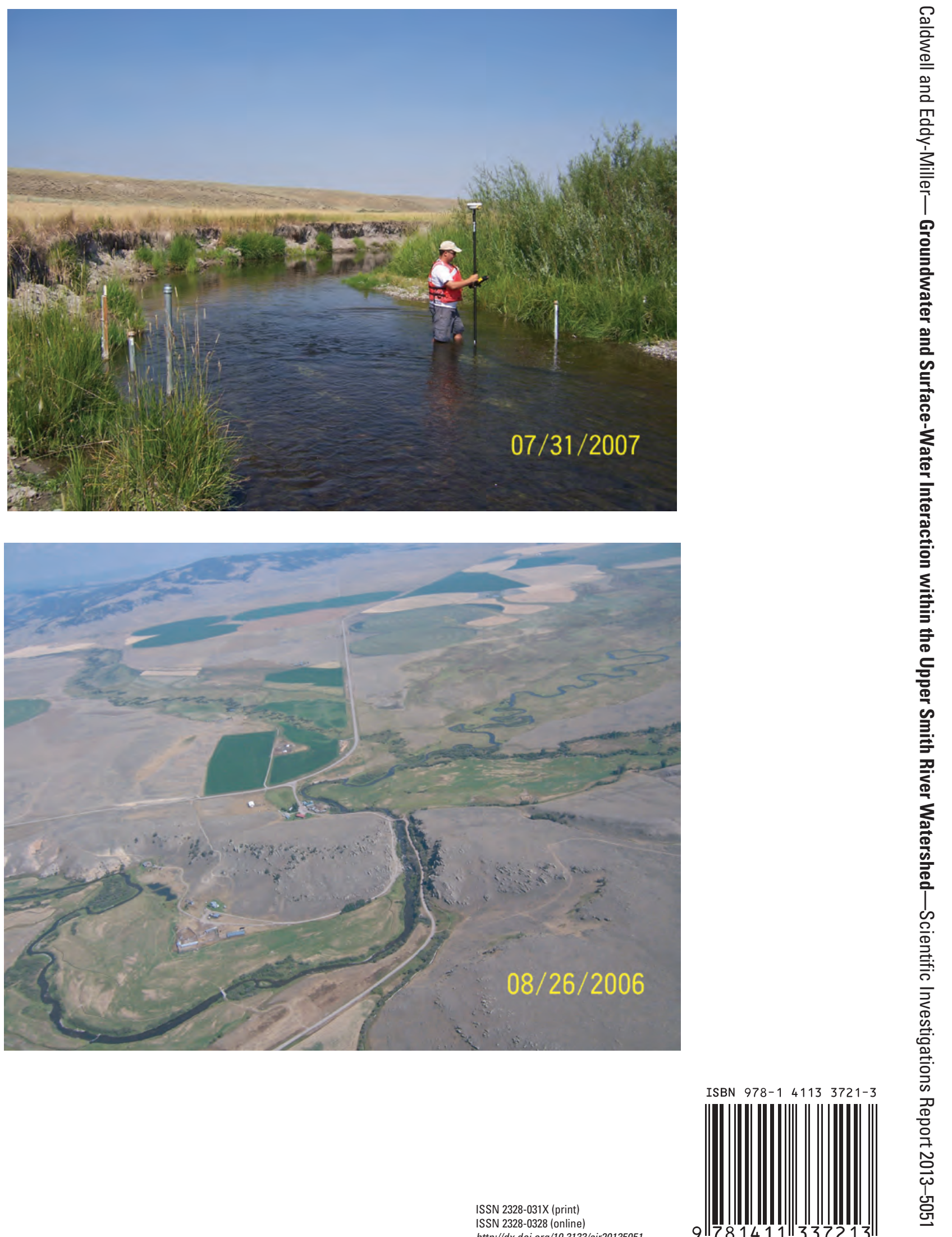